SÍLVIO EDUARDO VALENTE

\title{
DIRETIVAS ANTECIPADAS DE VONTADE PARA O FIM DA VIDA: UM ESTUDO À LUZ DO DIREITO PENAL
}

\author{
DISSERTAÇÃO DE MESTRADO
}

Orientador: Prof. Dr. Roberto Augusto de Carvalho Campos

FACULDADE DE DIREITO DA UNIVERSIDADE DE SÃO PAULO

SÃO PAULO

2014 
A Sueli, minha sempre companheira.

A André e Theo, nossos filhos.

A Valério, meu irmão.

A Valentim e Araci, meus pais. 


\section{AGRADECIMENTOS}

Aos professores e funcionários da graduação em Direito do Largo São Francisco.

Aos amigos construídos e cultivados nos bancos das Arcadas, em especial Amanda Lopes, Bruno Panarella, Felipe Dimov e Marlon Pereira.

Aos professores do Mestrado em Direito Penal, Medicina Forense e Criminologia da Faculdade de Direito da USP, em especial Prof. Titular Sérgio Salomão Shecaira e Prof. Livre-docente Alvino Augusto de Sá.

À Professora Livre-docente Janaína Conceição Paschoal e ao Prof. Dr. Henrique Caivano Soares, pelas preciosas indicações formais e materiais para este estudo.

Ao meu orientador, Prof. Dr. Roberto Augusto de Carvalho Campos, duplamente colega (médico e advogado), que me conduziu neste desafio preservando e estimulando minha autonomia. 


\section{RESUMO}

VALENTE, S. E. Diretivas antecipadas de vontade para o fim da vida: um estudo à luz do direito penal. 2014. Texto para Qualificação (Mestrado em Direito) - Faculdade de Direito da Universidade de São Paulo.

As diretivas antecipadas de vontade para o fim da vida são documentos que expressam os desejos da pessoa relacionados aos procedimentos que podem ser aplicados a ela em uma situação de assistência médica no fim da vida. Nesse sentido, as diretivas são úteis para informar as equipes de assistência médica a respeito dos tipos específicos de tratamento que o paciente permite, ou não permite, quando não estiver apto a manifestar suas vontades em uma hipotética situação futura de incapacidade. Este tipo de documento foi elaborado nos Estados Unidos na década de 1970, e foi introduzido no ordenamento ético brasileiro pela Resolução 1995/2012 do Conselho Federal de Medicina. O objetivo desta dissertação é estudar essa norma ética sob o enfoque do direito penal, uma vez que as diretivas antecipadas de vontade para o fim da vida possuem uma íntima relação com a ortotanásia e a eutanásia, que são passíveis de sanção penal no Brasil. Assim, é fundamental analisar as diretivas antecipadas utilizando as ferramentas da doutrina penal, e princípios como os da dignidade humana e razoabilidade. O objetivo é pesquisar as qualidades, imperfeições e limites das diretivas antecipadas sob o ordenamento jurídico nacional, e também compreender as bases legais das diretivas antecipadas, que são os institutos da autonomia e do consentimento.

Concluímos que, ainda que as diretivas antecipadas de vontade sejam uma norma ética bem-vinda, demandam algumas melhorias e refinamentos, que poderiam ser representados pelos planejamentos antecipados de tratamentos, um tipo de documento direcionado aos valores de vida das pessoas. Além disso, uma mudança de paradigma relacionada à eutanásia, particularmente a eutanásia passiva e a ortotanásia, no sentido de descriminalizá-las, seria importante para que as diretivas antecipadas tenham eficácia no Brasil.

Palavras-chave: Diretivas antecipadas de vontade. Testamento vital. Ortotanásia. Eutanásia. Planejamento antecipado de tratamentos. 


\begin{abstract}
VALENTE, S. E. Advance directives for dying patients: a study based on criminal law. 2014. Master's candidate (Qualification text) - Law School of University of São Paulo.

Advance directives for dying patients are documents which express personal desires related to procedures that may be applied to people in a situation of medical assistance in the end of life. In this sense, they are useful to make health assistance teams know about what kind of specific treatment the patients permit, or do not permit, when they are not able to communicate their wishes in a hypothetical and future situation of disability. This kind of document was created in the United States in the seventies, and entered Brazilian ethical law by Resolution 1995/2012 of the Federal Council of Medicine. The aim of this dissertation is to study this ethical rule by means of the criminal law, because advance directives have a close relation to euthanasia and ortothanasia, which are prone to criminal sanction in Brazil. Therefore, it is paramount to analyze the advance directives using the doctrinal tools of criminal law and principles like human dignity and reasonability. The goal is surveying the qualities, inadequacies and limits of advance directives under Brazilian law, and also to understand the legal basis of the advance directives, which are the institutes of autonomy and consent.

We concluded that, although advance directives for dying patients are a welcome ethical law, it demands some improvement and refinement, which could be represented by the advance care planning, a kind of document that is focused on the life values of people. Furthermore, a change of paradigm related to euthanasia, particularly passive euthanasia and ortothanasia, in the direction of making them apart of criminalization, would be vital to promote the adequate efficacy of the advance directives in Brazil.
\end{abstract}

Keywords: Advance directives. Living wills. Ortothanasia. Euthanasia. Advance care planning. 
"Estavam na antiga palude Padusa, no jarrete suarento da Bota, e que pouco mudara desde quando Ravena era uma aldeia lacustre. Terra de miasmas e insetos virulentos, com canais d'água indolente e lodaçais d'água estagnada que envenenam o ar. Na charneca triste e insalubre, o fim de Anita se precipitou. Seu corpo grácil se consumiu aceleradamente, como um círio exposto ao vento." (Valentim Valente. Anita Garibaldi, heroína por amor, 1949, p. 287) 


\section{SUMÁRIO}

\section{CAPÍTULO I}

INTRODUÇÃ

CAPÍTULO II

MÉTODO.

\section{CAPÍTULO III}

FUNDAMENTOS: EUTANÁSIA E ORTOTANÁSIA...............................13

1. Eutanásia e ortotanásia: aspectos gerais.............................................................13

2. Eutanásia sob o prisma da teoria do bem jurídico penal ........................................16

2.1. A evolução do conceito de bem jurídico penal...........................................17

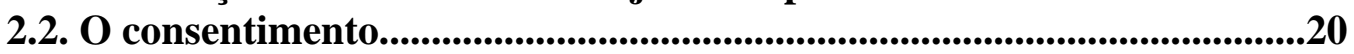

2.3. A eutanásia e o sopesamento de bens jurídicos..........................................25

CAPÍTULO IV

PRINCÍPIOS DA DIGNIDADE HUMANA E DA

RAZOABILIDADE.............................................................................................33

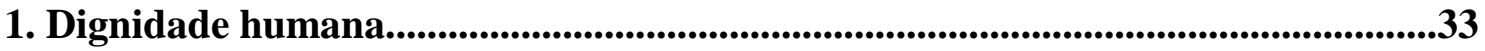

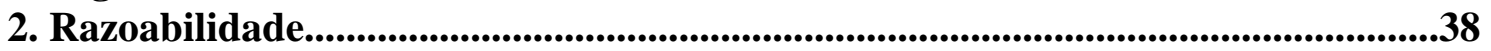

\section{CAPÍTULO V}

ABORDAGEM DOUTRINÁRIA E BIOÉTICA.......................................42

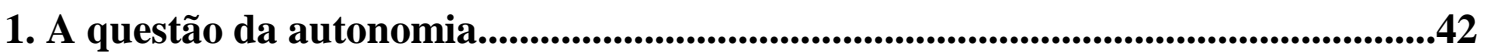

1.1. Autonomia como teoria geral...................................................................42

1.2. Psicologia da autonomia..........................................................................45

1.3. Autonomia e valores constitucionais.............................................................46

1.4. Autonomia e negócio jurídico.......................................................................48

1.5. Autonomia e bioética............................................................................50

2. Definições terminológicas das diretivas antecipadas de vontade..........................53

3. Origem e conceituação.........................................................................................................55

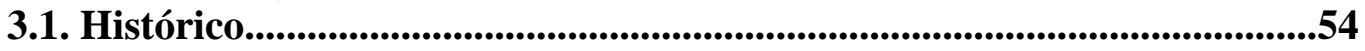

3.2. Abordagem conceitual...................................................................................56

4. Situações clínicas propícias às diretivas................................................................59

4.1. Patologias terminais...............................................................................59

4.2. Estados vegetativos persistentes...................................................................661

4.3. Quadros demenciais progressivos...........................................................62

4.4. Situações emergenciais...........................................................................64

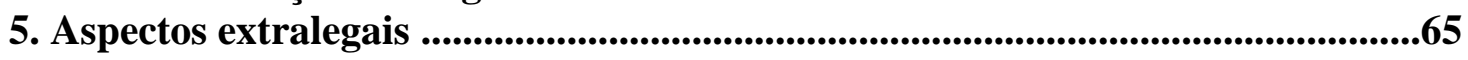

5.1. As diretivas sob o viés religioso.....................................................................66

5.2. As diretivas sob o viés bioético.....................................................................70

\section{CAPÍTULO VI}

TÓPICOS DE DIREITO COMPARADO.........................................73

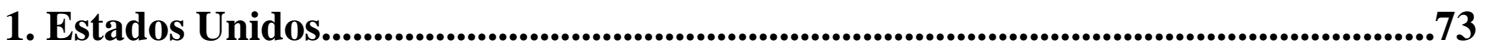

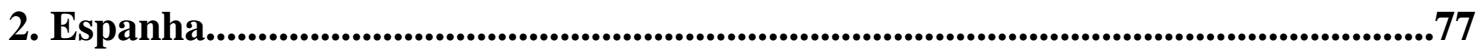

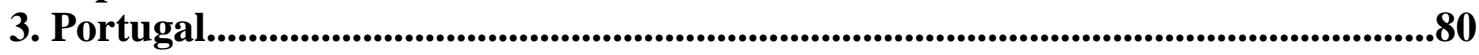

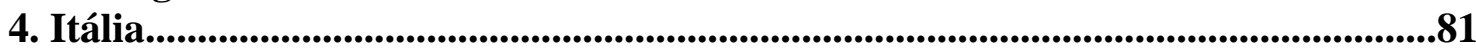




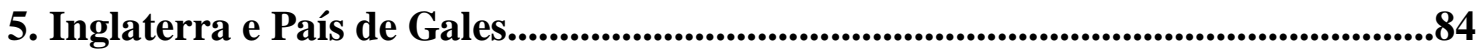

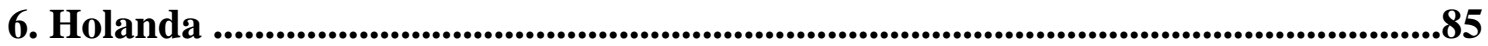

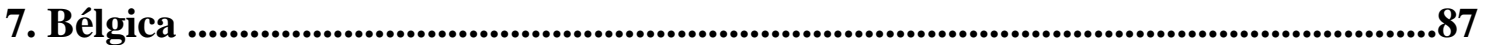

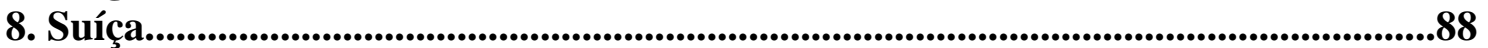

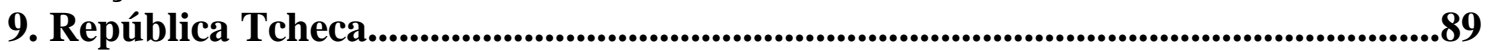

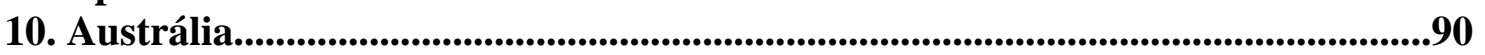

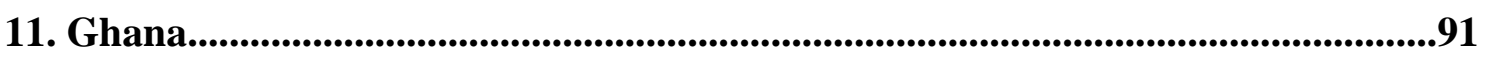

12. Turquia...............................................................................................................................................92

CAPÍTULO VII

APLICABILIDADE, CONSIDERAÇÕES CRÍTICAS E PERSPECTIVAS..................................................................................93

1. Fundamento e escopo da Resolução 1995/2012 do Conselho Federal de Medicina..........................................................................................................................93

2. A forma de comunicação da vontade...................................................................96

3. O representante para cuidados de saúde no fïm da vida.........................................99

4. Renovação, retificação e revogação das diretivas......................................................101

5. As diretivas aplicadas aos menores de idade..................................................................103

6. A conduta na ausência das diretivas antecipadas de vontade.................................104

7. A Resolução CFM 1995/2012 e o Código Penal...........................................................105

8. Das imperfeições e limitações do modelo normativo..........................................108

9. Um passo além das diretivas: planejamento antecipado de tratamentos...........111 10. Corolário: a perquirição dos valores do paciente direcionada à promoção da dignidade humana........................................................................................113

\section{CAPÍTULO VIII}

CONCLUSÃO....................................................................................115

REFERÊNCIAS BIBLIOGRÁFICAS......................................................116

ANEXOS..............................................................136

1. "Patient self determination act"'...................................................137

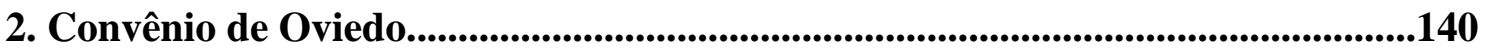

3. Resoluçãa 1995/ 2012 do Conselho Federal de Medicina...........................................150

4. Resolução 1805/ 2006 do Conselho Federal de Medicina....................................151

5. Lei Estadual 10241/ 1999 (São Paulo)...........................................................................152

6. Consulta 18688/ 2012 do Conselho Regional de Medicina do Estado de São Paulo......................................................................................................................155

7. Modelo de planejamento antecipado de tratamentos ("POLST").....................159 


\section{CAPÍTULO I. INTRODUÇÃO}

A Resolução 1995, de 2012, do Conselho Federal de Medicina, que introduziu em nosso meio o instituto das diretivas antecipadas de vontade para o fim da vida, se por um lado teve o condão de disponibilizar um importante instrumento de conduta médica, por outro deu azo a variados questionamentos em relação à sua aplicabilidade e alcance em solo pátrio. As dúvidas, correntes tanto nos meios médicos como nos jurídicos, lastreiam-se na atual carência de lei a respeito dessas diretivas, o que coloca os médicos na situação de serem norteados por uma recente norma ética de conduta, sem o correspondente respaldo legal. Isto se revela particularmente crucial em vista de estarmos frente a um instituto intimamente relacionado com a ortotanásia, e portanto também com a eutanásia. Ainda que a ortotanásia e alguns casos de eutanásia tenham uma aceitabilidade social crescente na atualidade, continuam sendo atos passíveis de sanção penal no Brasil.

O escopo bioético dessas diretivas é municiar os pacientes de um documento, nascido do moderno enfoque da autonomia das pessoas submetidas a terapêuticas médicas, que lhes brindaria com uma maior dignidade no processo da morte. Nesse sentido, a diretiva é um documento por meio do qual uma pessoa capaz, de posse de autonomia e de informação médica, explicita os limites que devem ser respeitados no que tange a sua assistência médica em condições clínicas no fim da vida. Assim, pode se recusar a ser submetida a certos procedimentos invasivos, muito comuns em situações de medicina intensiva, como a ressuscitação cardiopulmonar, intubação, nutrição parenteral prolongada e tantos outros. As diretivas antecipadas fundamentamse na possibilidade de o paciente não ter a capacidade de expressar livremente sua vontade em uma futura situação de suporte avançado da vida. Em regra são acompanhadas de uma procuração para instituir um terceiro que possa tomar decisões em condutas não explicitadas especificamente nas diretivas. É patente a importância desse documento, já que essas ocorrências fáticas tem se cristalizado cada vez mais, devido aos avanços da tecnologia médica em geral e da Medicina Intensiva em particular.

Para que se lance um olhar profundo sobre as diretivas antecipadas de vontade para o fim da vida, é mister compreender suas origens e também seu desenvolvimento, ambos se inserindo harmonicamente no próprio desenvolvimento da Bioética. Esta 
ciência, que floresceu na segunda metade do século passado, está longe de ter atingido sua plenitude, eis que seus conceitos estão em constante evolução e questionamento. Entretanto, suas raízes se fincam paulatina e solidamente na maior parte do mundo, sendo as diretrizes antecipadas de vontade para o fim da vida um feliz e promissor produto dessa essência.

A análise destas diretivas não pode se furtar à pesquisa de seus fundamentos e de sua eficácia em ordenamentos estrangeiros no qual já se percebem seus efeitos, principalmente o norte-americano e os de alguns países europeus, como a Espanha. Dessas fontes devem ser bebidas suas virtudes, mas também percebidas suas limitações e imprecisões, razão pela qual é parte desse trabalho uma abrangente abordagem de direito comparado.

Por outro lado, ainda que a avaliação das diretivas possa comportar vieses em direito civil, direito constitucional, e mesmo em filosofia e religião, é palpável que o instituto se amolda bem a uma pesquisa na seara penal, daí é principalmente nesse campo que semearemos. Isso porque, na experiência dúplice do autor como médico e como advogado, é justamente em sede criminal que podem surgir os principais percalços para que haja real efetividade do instituto onde ele deve, em última análise, interessar, ou seja, à beira do leito, modulando as decisões das equipes médicas. Isso não significa, porém, que outras áreas do direito não serão tangenciadas no tocante a algumas teorias nas quais as diretrizes antecipadas de vontade encontram embasamento, e isso fica bem evidente quando abordarmos o instituto da autonomia nessa pesquisa; nesse quesito, é inolvidável entrar na seara de teoria geral do direito, direito constitucional e direito civil, além de algumas questões extralegais, inescapáveis a quem se propõe a estudar tão polêmico tema.

Ainda que uma dissertação de mestrado deva visar uma aproximação da completude, sem, porém, dever ter a pretensão de concretizá-la, até porque o assunto é tão novo em solo pátrio, não é o objetivo desta pesquisa traçar espécie de manual de como confeccionar diretivas. Trabalhar-se-á aqui no pantanoso terreno dos conceitos de lege ferenda, mesmo havendo noviça resolução ético-profissional. Porém, ao pautar a pesquisa nos liames dos princípios da dignidade humana e da razoabilidade, muito caros em sede penal, abre-se a possibilidade de lançar âncoras para embasamento de futuros julgados em face dessas situações fáticas, certamente cada vez mais frequentes em futuro próximo. Ou seja, ao pavimentar a análise com um fundamento principiológico, 
pode-se oferecer ao julgador uma base doutrinária que se converta, quiçá, em vindoura jurisprudência.

O objetivo dessa pesquisa é realizar um estudo vertical das diretivas antecipadas de vontade para o fim da vida, avaliando sua aplicabilidade e seus limites, tendo como base a recente Resolução 1995, de 2012, do Conselho Federal de Medicina, que entronizou o instituto no ordenamento médico-ético no Brasil. Esse estudo, feito à luz da moderna doutrina penal que envolve a ortotanásia, incluirá sua percepção sob a ótica da teoria de bem jurídico penal, ainda fundamental em sede de direito criminal. Desta abordagem constará uma análise preliminar sobre o consentimento, e um estudo sobre a ortotanásia sob o viés do sopesamento dos bens jurídicos. Os princípios da dignidade humana e da razoabilidade, cujos enfrentamentos são inescapáveis ao pretendermos abordar um instituto de cunho bioético, merecerão um capítulo. A seguir, entraremos no assunto das diretivas antecipadas propriamente, situando o problema sob o prisma da autonomia, e depois mergulhando em definições, nomenclatura, e as situações clínicas em que se pode aplicar o instituto. Desse ponto também constará uma abordagem das diretivas sob o viés religioso e bioético, vez que a aceitabilidade social do tema não pode ser apartada de um prisma ôntico. O direito comparado, do qual evocaremos alguns tópicos, servirá de bússola para vislumbrarmos a possível eficácia das diretivas antecipadas no Brasil, já que alguns países, principalmente os Estados Unidos, acumulam larga experiência no assunto. Voltando o foco para o ordenamento nacional, a Resolução CFM 1995/2012 será dissecada em relação às suas características, aplicabilidade e limites. Na sequência, as diretrizes merecerão uma análise crítica, visando perscrutar até que ponto convém que se cristalizem em lei, ou se, pelo contrário, andam melhor na trilha específica das normas bioéticas. Analisaremos a possível antinomia entre uma norma ética que estimula a ortotanásia, e uma norma de cunho penal que, em tese, a veda. Por fim, enfrentaremos a nova e alternativa perspectiva do planejamento antecipado de tratamentos, fechando a pesquisa com as análises conclusivas. 


\section{CAPÍTULO II. MÉTODO}

As diretivas antecipadas de vontade para o fim da vida serão dissecadas sob a ótica do direito penal. Para concretizar a proposta dessa pesquisa, será analisada preliminarmente a doutrina atual sobre a eutanásia e a ortotanásia, institutos intimamente relacionados com as diretivas antecipadas de vontade para o fim da vida, à luz da teoria do bem jurídico penal e de princípios vitais para o direito criminal, como os da dignidade humana e razoabilidade.

A autonomia e o consentimento merecerão abordagem específica, pois fazem parte da essência das diretivas antecipadas de vontade. Estas serão estudadas de forma aprofundada, partindo de aspectos de nomenclatura, e passando por suas características, aplicabilidade, limites e imperfeições, lançando mão, com esse escopo, do direito comparado. Dentro desse aprofundamento, as diretivas serão perscrutadas de forma crítica, com vistas a avaliar a real possibilidade de utilização da Resolução 1995/2012 do Conselho Federal de Medicina no ordenamento jurídico brasileiro. Nessa linha, será lançado um olhar para as proposições alternativas às diretivas antecipadas de vontade, que começam a surgir em outros países, com o fim de tentar otimizar suas qualidades e suprir suas lacunas. 


\section{CAPÍTULO III. FUNDAMENTOS: EUTANÁSIA E ORTOTANÁSIA}

\section{Eutanásia e ortotanásia: aspectos gerais}

O estudo jurídico dos institutos da ortotanásia e da eutanásia se reveste de importância crescente na atualidade. Isso se prende a vários fatores. Em primeiro lugar, as condições da vida contemporânea, no que se convencionou denominar de sociedade de risco, criam o substrato para que surjam, de um lado, novas e às vezes graves patologias, tendo sua gênese em um rol amplo que abarca desde novas fontes de radiação até exposição do ser humano a meios de transporte e de lazer mais velozes, passando pelos alimentos industrializados e pela poluição, além do uso às vezes excessivo de medicamentos e de drogas em geral. Pari passu, o estilo de vida atual, que alia busca pela produtividade e pela eficiência, em detrimento da privacidade e do lazer, somado ao evidente aumento de expectativa de vida, deságua em uma maior prevalência de doenças degenerativas. Por outro lado, a medicina, ainda curativa por excelência, e irmanada com a biotecnologia, caminha no sentido de prover solução ou no mínimo paliação a essas situações clínicas.

Desse caldo, cristalizam-se situações de suporte avançado da vida, em que o ser humano é submetido a uma gama de procedimentos diagnósticos e terapêuticos, muitas vezes bastante desconfortáveis. Tais procedimentos, vistos sob a ótica da "ciência dura", são muito satisfatórios no sentido de manutenção das condições vitais dos pacientes. Entretanto, acabam por fomentar uma dramática situação de sofrimento daquele que é seu objeto, ou seja, o próprio paciente. Ademais, às vezes ocorre, por parte das equipes de saúde, uma verdadeira "obstinação terapêutica"1 em face de doentes cujo prognóstico é fechado, conotando uma espécie de calvário.

Atenta a esse problema, a medicina tem procurado criar um novo paradigma de assistência, usando a ferramenta dos denominados "cuidados paliativos", erigidos atualmente a uma nova especialidade médica. Nesse diapasão, entendendo a morte

1. BORGES, Roxana Cardoso Brasileiro. Direito de morrer dignamente: eutanásia, ortotanásia, consentimento informado, testamento vital, análise constitucional e penal, e direito comparado. In: SANTOS, Maria Celeste Cordeiro Leite (org.). Biodireito: ciência da vida, os novos desafios, 2001, p. 284. 
não como um evento e sim como um processo $^{2}$, as equipes de terapia intensiva direcionam seus esforços, em muitos casos, não visando a manutenção da vida a qualquer preço, mas sim o conforto do paciente-cliente.

O direito, porém, mais uma vez vindo a reboque das biociências no sentido de assegurar o necessário embasamento jurídico para as novas situações fáticas que se consubstanciam de forma cada vez mais premente, e com evidentes repercussões pragmáticas, encontra-se, em solo pátrio, embrionário nesse tema. A doutrina tem se interessado pelo assunto, porém a positivação inexiste e, concomitantemente, a jurisprudência patina. Assim, um estudo dedicado ao tema deve obrigatoriamente buscar doutrina estrangeira, o que, frise-se, nem parece equivocado, vez que o próprio Norberto Bobbio enxerga o direito, sob o conceito de busca da justiça, como um sistema dotado de coerência e coesão ${ }^{3}$.

Nessa linha, importa considerar, para este estudo, algum aclaramento quanto ao conceito de ortotanásia e termos correlatos, como a eutanásia. Ainda que alguns considerem a eutanásia como gênero que abarca diversas espécies, a doutrina mais moderna tem procurado separar esse termo de suas antigas "modalidades", eis que por vezes os conceitos são opostos, como é o caso do confronto da ortotanásia com a distanásia, como será visto adiante.

De qualquer forma, o termo eutanásia guarda em seu bojo algo de generalidade, significando "boa morte", e justamente daí é que deriva seu objeto ${ }^{4}$. Reza o sentido clássico, porém, que a eutanásia envolve sempre uma motivação humanitária, seja ela em face da própria pessoa ou da sociedade ${ }^{5}$. Delimitando de forma mais consistente, a eutanásia somente se aplica a paciente com “doença grave, incurável e terminal”, , ainda

2. PESSINI, Leocir; BARCHIFONTAINE, Christian de Paul. Problemas atuais de bioética, 2008, p. 466. Os autores comentam que atualmente o lapso temporal estimado entre a descoberta da doença e a morte gira em torno de cinco anos, razão pela qual é considerado um processo.

3. BOBBIO, Norberto. Teoria generale del diritto, 1993, p. 234. "Là dove de coerenza non è condizione di validità, è però pur sempre condizione per la giustizia dell'ordinamento."

4. GONZÁLEZ ALCÁNTARA, Juan Luis. Testamento vital y eutanasia, 2008, p. 21. O autor aponta a natureza genérica do vocábulo nesses termos: “...el objeto de la eutanasia deriva de su próprio significado; este significa "buena muerte". Pero no implica de por si acción alguna de parte de alguién. Bajo tal contexto, cualquier persona que tiene o tuvo una buena muerte tiene o tuvo eutanasia, y todos, si tenemos sentido común, anhelamos por ella."

5. PESSINI, Leocir; BARCHIFONTAINE, Christian de Paul, op. cit., p. 502.

6. SANTOS, Maria Celeste Cordeiro Leite dos. Contornos atuais da eutanásia e da ortotanásia: bioética e biodireito, a necessidade do controle social das técnicas médicas, 2000, p. 21. 
que o termo "grave" pareça aqui desnecessário, vago e redundante, em face dos dois últimos qualificadores.

Existe uma classificação usual que delimita a eutanásia em ativa e passiva, sendo a primeira consequente a atitudes comissivas da equipe de saúde, e a segunda derivada de omissões. Não parece ser a abordagem mais adequada para a análise do instituto da eutanásia atualmente ${ }^{7}$, visto que embute uma espécie de diferenciação moral que pode levar a uma distorção de julgamento entre as modalidades. Porém é a mais usual na doutrina.

Nesse ponto, convém esmiuçar o conceito de ortotanásia, que muitos confundem erroneamente com eutanásia passiva. Como foi dito, enquanto esta última se concretiza com atos de omissão, e.g. deixar de alimentar um paciente terminal, a ortotanásia se reveste de uma suavidade na condução do processo da morte. Nesse sentido, o profissional de saúde utiliza de sua expertise e dos recursos disponíveis não para abreviar, mas para tornar o desfecho terminal mais palatável para o moribundo. Aqui se incluem, por exemplo, a utilização de sedativos e analgésicos.

Nessa linha, é interessante ressaltar que, uma vez que se entenda a ortotanásia como não determinante, nem sequer aceleradora do processo da morte, haveria exclusão da própria tipicidade ${ }^{8}$. Assim há quem advogue a ausência da tipicidade material na ortotanásia, pela ação não ter valoração negativa ${ }^{9}$.

Conceitualmente, atribui-se a criação do termo ortotanásia a Jacques Roskam, da Universidade de Liège (Bélgica) ${ }^{10}$, em 1950, em que o autor opõe o procedimento ortotanásico ao da distanásia, sendo que nesta a equipe de saúde toma atitudes obstinadas para manter a vida a qualquer custo, mesmo que à custa da indignidade e da agonia aumentada pela disponibilidade de aparato tecnológico ${ }^{11}$. Ou seja, a distanásia é diametralmente oposta à ortotanásia, e como tal deve ser repudiada.

7. PESSINI, Leocir; BARCHIFONTAINE, Christian de Paul, op. cit., p. 502.

8. GUIMARÃES, Marcello Ovídio Lopes. Eutanásia - novas considerações penais, 2011, p. 129. Jorge de Figueiredo Dias caminha pela mesma trilha ao afirmar que "o auxílio médico à morte é incondicionalmente lícito sempre que operado sem encurtamento do período natural de vida.", DIAS, Jorge de Figueiredo. O problema da ortotanásia: introdução e sua consideração jurídica, 2005, p. 23.

9. GOMES, Luiz Flávio. Ortotanásia: morte digna?, 2011, p. 57.

10. OLIVEIRA, Damião Alexandre Tavares. Dignidade da pessoa humana, cuidados paliativos $e$ ortotanásia: a visão de um juiz, 2012, p. 34.

11. BETANCOR, Juana Teresa. El testamento vital, 1995, p. 110. 


\section{Eutanásia sob o prisma da teoria do bem jurídico penal}

A eutanásia, como sói ocorrer com diversas áreas do Biodireito e da Bioética, tem sido um tema desafiador para o estudioso da matéria penal. A preocupação a respeito da eutanásia caminha acoplada ao avanço da Medicina em geral, e particularmente da Medicina Intensiva. Isso porque a ciência médica consegue, atualmente, estender artificialmente a preservação da vida a limites inimagináveis há poucas décadas ${ }^{12}$, o que acaba criando situações peculiares, com relevantes reflexos jurídicos. Não obstante muito se tenha escrito sobre esse palpitante assunto, o jurista que se debruça sobre o problema ainda se ressente da falta de um posicionamento dogmático mais cristalino. Além disso, ao contrário de outros ordenamentos jurídicos ${ }^{13}$, nosso Código Penal eloquentemente silencia sobre a eutanásia e ortotanásia. Ainda que tenha havido projetos de lei que versaram a respeito ${ }^{14}$, todos foram arquivados.

Certamente, muito dessa indefinição se deve à aparente falta de diálogo entre o Direito, ciência humana, e a Medicina, ciência biológica "dura", voltada à busca do bem-estar e da preservação da vida. Além disso, o conceito de morte, fulcro inolvidável da análise da eutanásia, em geral, e da ortotanásia, em particular, é caixa de ressonância de definições sociológicas, filosóficas e religiosas. Busca-se, nesse capítulo, avaliar o bem jurídico penal como ferramental auxiliar na busca de definições no tocante às decisões médicas em relação ao paciente no fim da vida.

O significado etimológico da palavra "eutanásia", de origem grega, é sobejamente conhecido: boa morte, ou morte sem sofrimento. Claus Roxin define o termo como "ajuda prestada a uma pessoa gravemente doente, a seu pedido, ou pelo menos em consideração à sua vontade presumida, no intuito de lhe possibilitar uma morte compatível com a sua concepção da dignidade humana"15.

12. PESSINI, Leocir; BARCHIFONTAINE, Christian de Paul. Problemas atuais de bioética, 2008, p. 493. Os autores discorrem sobre o fato de que ao mesmo tempo em que a ciência aumentou a expectativa de vida, também prolongou o processo da morte.

13. DIAS, Jorge de Figueiredo. A "ajuda médica à morte": uma consideração jurídico-penal. In: Revista Brasileira de Ciências Criminais, n. 100, v. 21, 2013, p. 17. A esse respeito, Jorge de Figueiredo Dias nos remete ao direito da Holanda, Bélgica e Luxemburgo, em que há positivação sobre a eutanásia, cuja autorização jurídica depende de condicionamentos estritos. Em contrapartida, lembra o autor que a legislação de Alemanha e Portugal não se pronuncia sobre o tema.

14. Nessa linha, Iberê Anselmo GARCIA cita os projetos de lei: 5058/2005, do Deputado Osmânio Pereira; 732/83, do Deputado Inocêncio Oliveira; 125/96, do Senador Gilvan Borges; e 116/2000, do Senador Gérson Camata. Vale citar que esses projetos não caminharam no mesmo sentido em relação à autorização legal da eutanásia. Aspectos médicos e jurídicos da eutanásia. Revista Brasileira de Ciências Criminais, n.67, v. 15, 2007, p. 267.

15. ROXIN, Claus. A apreciação jurídico-penal da eutanásia. Revista Brasileira de Ciências Criminais, v. 8, n. 32, out-dez. 2000, p. 10. 
É patente que na própria definição assumida pela doutrina se encontra insculpido o conflito entre dois bens jurídicos considerados fundamentais, quais sejam a vida e a dignidade humana.

Assim, nesse capítulo do estudo será avaliada a possibilidade de procurar respaldo na teoria do bem jurídico penal, com o fulcro de embasar dogmaticamente o importante problema jurídico, médico e bioético do auxílio à morte. Para isso, serão revistas as principais correntes evolutivas na teoria do bem jurídico. A seguir, será analisado o cabimento da aplicação do enfoque atual dessa teoria, no que tange ao instituto da eutanásia, especialmente em relação às questões do consentimento e do sopesamento de bens jurídicos necessários para sua análise.

\subsection{A evolução do conceito de bem jurídico penal}

Segundo o pensamento de Von Liszt, a noção de bem jurídico se contrapõe ao conceito de objeto da ação, no sentido de o bem jurídico ter seu "locus" no plano normativo, enquanto o objeto material é encontrado no plano naturalístico ${ }^{16}$. Ferrajoli, por sua vez, chama a atenção para o aspecto valorativo do conceito de bem jurídico, no sentido de que sua lesão seja o mote para justificar a pena ${ }^{17}$. Reportando-se a Kant, ele pontua que a compatibilização das liberdades de cada um, apartada do viés teológico ou ético, está no cerne da tutela penal dos interesses necessários ou fundamentais ${ }^{18}$.

A ideia de bem jurídico penal nasce com o movimento iluminista, a partir do pensamento de Feuerbach do delito como lesão a um direito subjetivo ${ }^{19}$. Porém a expressão surge com Birnbaum, em 1834, atribuindo ao bem jurídico não apenas um caráter positivo, mas também de valoração social ${ }^{20}$.

16. PRADO, Luiz Regis. Curso de direito penal brasileiro - vol. 1, 2008, p. 246.

17. FERRAJOLI, Luigi. Direito e razão - teoria do garantismo penal, 2006, p. 428. A esse respeito, o autor comenta que o bem jurídico atende ao princípio utilitarista do direito penal, sendo a lesividade do resultado "seu principal limite axiológico externo".

18. FERRAJOLI, Luigi, op. cit., p. 429.

19. LOPES, Maurício Antonio Ribeiro. Critérios constitucionais de determinação dos bens jurídicos penalmente relevantes, 1999, p. 327.

20. BECHARA, Ana Elisa Liberatore Silva. Da teoria do bem jurídico como critério de legitimidade do direito penal. 2010, p. 90 e 91. A autora explica que, em contraste com Feuerbach, que enxergava o delito como lesão a um direito subjetivo, Birnbaum o considera lesão a um bem. Ainda que seus críticos, notadamente Amelung e Hormazábal Malarée, não considerassem a concepção de Birnbaum como limitadora do direito penal, eis que eivada de vacuidade e assim sujeita a influências políticas, seus defensores (Bustos Ramírez e Schünemann) reconhecem o mérito de sua doutrina como promotora do direito penal mínimo. BECHARA, A. E. L. S., op. cit., pp. 92 e 93. 
Posteriormente, Binding inaugurou a visão positivista do bem jurídico, segundo o qual bem jurídico significava aquilo que o ordenamento jurídico assim o considerasse. Abraçando o positivismo jurídico de Auguste Comte, esse autor retirou do bem jurídico qualquer resquício social, apartando-o de aspectos filosóficos, sociais e metajurídicos ${ }^{21}$. Binding teve o mérito da cientificidade em termos de norma penal, ainda que sua concepção de bem jurídico possa carrear um viés autoritário ${ }^{22}$.

Perceba-se que Liszt, assim como Binding, também é um positivista, porém dá ao bem jurídico uma porosidade ao ambiente social que não se encontra na doutrina deste último ${ }^{23}$. Binding, por seu turno, impermeabiliza o sentido do bem jurídico na direção de ater-se à letra da lei.

A contraposição essencial entre as ideias de Von Liszt e Binding, com este se aferrando ao que está explicitado na norma, e aquele construindo uma função mais crítica para o que viria a se denominar bem jurídico, vai permear as discussões contemporâneas dos autores que se seguiram, e persiste na atualidade. Até porque hoje estão patentes novas concepções e problemas que antes não eram palpáveis, exempli gratia os bens jurídicos meta-individuais.

No percurso evolutivo da teoria do bem jurídico penal, a inspiração de Auguste Comte, concebida como contraponto ao racionalismo hegeliano, foi o combustível para o desenvolvimento do positivismo jurídico de Binding ${ }^{24}$. Nessa linha de pensamento, o direito é considerado um complexo de normas, apartado de qualquer aferição de conteúdo, e portanto ancorado à atividade volitiva do Estado-legislador.

O positivismo naturalista, que veio a seguir, expressava a preocupação de Franz von Liszt com “a delimitação das ações que devem ser declaradas puníveis pelo Estado,

21. BECHARA, Ana Elisa Liberatore Silva, op. cit., p. 95. “...nenhum objeto tem valor normativo se não estiver fundado em critérios correspondentes ao ordenamento jurídico em si, cujo antecedente causal é representado pela própria vontade do Estado." Destarte, para Binding o bem jurídico está inserido no próprio texto legal, sendo portanto o legislador quem o define (op. cit., p. 96). A crítica que se faz a essa concepção é que daria azo a postulações autoritárias por parte do legislador. Nesse diapasão, ZAFFARONI e PIERANGELI pontuam a doutrina do mestre alemão, perquirindo, com alguma ironia: "se Binding tivesse vivido o suficiente para ver o direito penal dos autoritarismos do período entreguerras, não manteria sua afirmação" ZAFFARONI, Eugenio Raul; PIERANGELI, José Henrique. Manual de direito penal brasileiro, v. 1 2007, p. 267.

22. ZAFFARONI, Eugenio Raul; PIERANGELI, José Henrique, op. cit., p. 268.

23. LOPES, Maurício Antonio Ribeiro. Critérios constitucionais de determinação dos bens jurídicos penalmente relevantes, 1999, p. 336.

24. BECHARA, Ana Elisa Liberatore Silva, op. cit., p. 95. 
ultrapassando-se, desse modo, a interpretação do bem jurídico como mera ratio legis" e também até que ponto a fundamentação da pena era retribuição ao cometimento do delito, ou se tinha como aparato a proteção dos bens jurídicos ${ }^{25}$.

Já no século XX, Welzel embasou o direito penal no cumprimento de deveres ético-sociais mediante imposição de sanções. Suas ideias imiscuíam-se com as de Von Liszt no tocante ao fundamento do bem jurídico como protetivo a bens vitais ao indivíduo ou à comunidade, mas dele se diferenciavam ao considerar o bem jurídico alheio a qualquer natureza jurídico-positivista ${ }^{26}$.

Ao final do século passado, esboçaram-se duas linhas de raciocínio em face do bem jurídico: a constitucional e a social. A primeira considera o bem jurídico lastreado na Carta Magna, enquanto as considerações sociológicas inserem o bem jurídico na realidade social, vinculando-o às ciências sociais ${ }^{27}$.

Pela perspectiva constitucional, a fundamentação de validade do Direito Penal encontra seu norte no texto constitucional. Isso acaba por retirar a abstração do bem jurídico, dando-lhe uma raiz fortemente sulcada no tipo de Estado que da Constituição emana $^{28}$. Renato Silveira lembra que essa tese foi abraçada por Roxin e pela doutrina italiana majoritária, na linha de que a Constituição seria limite negativo para a eleição de bens jurídicos, balizando o próprio poder punitivo do Estado ${ }^{29}$. A crítica que se faz a esse tipo de concepção do bem jurídico é que resulta em uma maior possibilidade de criminalização de condutas por parte do legislador, respaldado no viés protetivo em face de ofensas principalmente a bens de natureza supraindividual ${ }^{30}$.

No viés sociológico, por sua vez, encontramos em Hassemer um de seus principais defensores. Nesse entendimento, o bem jurídico é visualizado como tendo respaldo em uma possibilidade de dano à sociedade, ainda que não lance por terra os

25. BECHARA, Ana Elisa Liberatore Silva, op. cit., p. 99.

26. SILVEIRA, Renato de Mello Jorge. Bem jurídico-penal: leituras conflituosas, 2012, p. 133.

27. SILVEIRA, Renato de Mello Jorge, op. cit., p. 134.

28. LOPES, Maurício Antônio Ribeiro, op. cit., 1999, p. 394.

29. SILVEIRA, Renato de Mello Jorge, op. cit., p. 134. No mesmo sentido, Ana Elisa Bechara pontua que "Passa-se, então, a buscar na Constituição, como fonte normativa suprema de todo o ordenamento jurídico, os objetos aos quais deve o direito penal conferir proteção. A razão da determinação do conteúdo do bem jurídico pelos valores consagrados na lei fundamental baseia-se na própria ideia da pena. Assim, se a sanção penal é apta a afetar diretamente os direitos constitucionalmente protegidos, o direito penal deve proteger apenas valores também consagrados na lei fundamental." BECHARA, Ana Elisa Liberatore Silva, op. cit., p. 119.

30. BECHARA, Ana Elisa Liberatore Silva, op. cit., p. 127. 
aspectos constitucionais ${ }^{31}$. Hans Hirsch lembra que Hassemer colocava os liames do bem jurídico a partir de um prisma pré-jurídico e pessoal ${ }^{32}$. Notável representante da Escola de Frankfurt, Hassemer fala de um conceito apriorístico de bem jurídico, a partir do qual o direito penal centraria sua mira na tutela de interesses diretos ou indiretos da pessoa, daí derivando uma visão de oposição do bem jurídico como protetivo do meioambiente e outros bens supraindividuais ${ }^{33}$.

Ainda que, para discutirmos os bens jurídicos relacionados com a eutanásia, não precisemos adentrar as polêmicas afetas aos bens jurídicos não pessoais, este escorço histórico é válido para que possamos nos situar no pleno entendimento da questão. Para isso, carece não nos olvidarmos, como bem cita Alessandro Baratta, da dupla função do bem jurídico: uma imanente ao sistema positivo, e outra extrajurídica ${ }^{34}$. O conflito dogmático entre a visão positivista e o viés jusnaturalista transcende a teoria do bem jurídico penal, sendo inerente à própria construção do direito como um todo ${ }^{35}$.

\section{$2.2 \mathrm{O}$ consentimento}

As condutas médicas atualmente tem se pautado por dar respaldo à opinião e consentimento do paciente. O Código de Ética Médica anterior, de 1988, foi elaborado com inspiração na "mens leges" do legislador constituinte, tendo foco nos direitos individuais do paciente. O atual Código, de 2009, mesmo saudavelmente preservando aqueles valores, se pauta por um viés mais consumerista, isto é, tendo como fonte inspiradora o Código de Defesa do Consumidor (2002), mesmo que explicitamente aparte o ato médico da mera relação de consumo ${ }^{36}$. Nesse sentido principiológico, o

31. SILVEIRA, Renato de Mello Jorge, op. cit., p. 135.

32. HIRSCH, Hans Joachim. Acerca del estado actual de la discusión sobre el concepto de bien jurídico, 2000, p. 371.

33. HIRSCH, Hans Joachin, op. cit., p. 374.

34. BARATTA, Alessandro. Les fonctions instrumentales et les fonctions symboliques du droit penalpor une théorie du bien juridique. 1991, p 1. Ensina o autor que "A primeira função corresponde à interpretação teleológica das normas penais e à sua construção sistemática. A consequência dogmática principal dessa utilização intra-sistêmica do conceito de bem jurídico se refere à duplicidade do comportamento contrário à lei: sob o plano formal, o comportamento contrário à lei consiste na violação da norma social ou jurídica concernente aos tipos de infração (Binding); sob o aspecto material, o comportamento contrário à lei consiste na violação ou na colocação em perigo do interesse protegido pela norma. Falaremos de responsabilidade penal quando as duas formas de comportamento contrário à lei se realizarem. A violação material pressupõe, todavia, a violação formal como condição de existência." (tradução livre do autor)

35. BOBBIO, Norberto. Teoria generale del diritto. 1993, p. 35.

36. "A natureza personalíssima da atuação profissional do médico não caracteriza relação de consumo" Código de Ética Médica, 2009, Capítulo I, artigo XX. 
paciente é visto como cliente, que deve ser informado da forma mais completa possível sobre os serviços que lhe serão prestados, podendo opinar e consentir ${ }^{37}$.

$\mathrm{Na}$ prática médica, esse direito de ser informado se consubstancia no "consentimento informado", documento no qual o paciente, na consulta médica, atesta sua ciência sobre os diagnósticos, as opções terapêuticas, e os potenciais riscos e efeitos colaterais. O consentimento informado, que tem natureza contratual, "é condição necessária para que se dê o início do tratamento" ${ }^{\text {38 }}$, e pode ser o veículo para o paciente expressar sua recusa a determinada modalidade terapêutica.

No âmbito da doutrina penal, por sua vez, o consentimento fundamenta uma possibilidade de renúncia por parte do titular do bem jurídico, ou seja, a vítima assume, expressa ou tacitamente, seu quinhão de responsabilidade no delito ${ }^{39}$. Manuel Cancio Meliá chama a atenção para a questão da possibilidade de disposição de alguns bens jurídicos como requisito para a utilização jurídica do consentimento ${ }^{40}$. Pontua o autor que a teoria do consentimento abarca duas visões doutrinárias: aquela que considera o consentimento fator de atipicidade e aquela que afasta a antijuridicidade.

$\mathrm{Na}$ abordagem que afasta a tipicidade em face do consentimento da vítima, entende-se que a interação desta com o agente ocupa um papel fulcral na própria definição do crime, e isso não pode ser ignorado pelo Direito Penal ${ }^{41}$. Tal visão segue os conceitos da imputação objetiva, e deve, por óbvio, seguir estritamente os liames para qualquer consentimento válido, como ausência de vício de vontade, capacidade do consensciente em consentir, bons costumes, ordem pública e, sobretudo, disponibilidade do bem jurídico a respeito do qual se irá consentir.

Deve-se asseverar, porém, que o tratamento da questão no plano da tipicidade pode gerar um poder exoneratório de responsabilidade ao comportamento da vítima, de

37. "É vedado ao médico: deixar de garantir ao paciente o exercício do direito de decidir livremente sobre sua pessoa ou seu bem-estar, bem como exercer sua autoridade para limitá-lo." Código de Ética Médica, 2009, Capítulo IV, artigo 24.

"É vedado ao médico: desrespeitar o direito do paciente ou de seu representante legal de decidir livremente sobre a execução de práticas diagnósticas ou terapêuticas, salvo em caso de iminente risco de morte." Código de Ética Médica, 2009, Capítulo V, artigo 31.

38. SCAFF, Fernando Campos. Direito à saúde no âmbito privado: contratos de adesão, planos de saúde e seguro-saúde, 2010, p. 93.

39. MELIÁ, Manuel Cancio. Conducta de la víctima y imputación objetiva en derecho penal - estudio sobre los ambitos de responsabilidad de víctima y autor en actividades arriesgadas, 2001, p. 148. O autor também remete à distinção feita por Claus Roxin entre a autocolocação da vítima em risco e a heterocolocação da vítima em risco consentida pela própria vítima.

40. MELIÁ, Manuel Cancio, op. cit., p. 149.

41. GRECO, Alessandra Orcesi Pedro. A autocolocação da vítima em risco, 2004, p. 90. 
uma maneira que pode extrapolar os limites do Direito Penal ${ }^{42}$. Ensina Meliá que, de resto, o conceito de consentimento como razão afeita à causa de justificação, e não à tipicidade, fornece maior segurança jurídica, eis que evita julgados arbitrários e critérios paternalistas "ad hoc" 43 .

Nessa linha, o consentimento exprime a vontade da vítima acerca da disposição sobre bens. Essa expressão só pode exsurgir tendo como liames os âmbitos de responsabilidade, que por sua vez são determinados em conformidade a normas especiais incriminadoras ${ }^{44}$. Porquanto o Direito Penal clássico desvincule essa responsabilidade do comportamento da vítima, assumindo a posição desta e substituindo-a, a visão mais contemporânea da ciência penal tem voltado seus olhos para a conduta daquele que sofre o dano ${ }^{45}$. Nesse diapasão, surge a Vitimodogmática, que passa a enxergar a vítima não mais como mero sujeito passivo do delito, mas como objeto de responsabilidade.

Configura-se dúvida doutrinária a respeito de o consentimento afastar a própria tipicidade, como quer Schünemann, ou, pelo contrário, o ato de consentir ter o condão de se restringir ao plano da ilicitude; essa última colocação observa o consentimento sob a ótica da indisponibilidade do bem jurídico lesado ${ }^{46}$. Eis aqui a questão crucial que norteia a validade jurídica do consentimento, uma vez que havendo carência de disponibilidade a proteção penal do bem jurídico não pode ser afastada, ainda que seu titular o consinta.

Porém, ainda que se admita a indisponibilidade de bens jurídicos caros à sociedade, na esteira do caráter público do direito penal ${ }^{47}$, há que se ter em mente que o tecido social cambia constantemente. Como efeito dessa mobilidade valorativo-social, a pertinência da tutela penal passa a ser flexibilizada, pois o conceito de bem jurídico penal passa a ser visto como interesse, e não como dever ${ }^{48}$.

42. MELIÁ, Manuel Cancio, op cit., 2001, p. 152. Para fundamentar esse raciocínio, o autor se reporta a W. FRISCH. Comenta que o posicionamento dogmático recente situa os âmbitos de responsabilidade como pertinentes à tipicidade.

43. MELIÁ, Manuel Cancio, op. cit., p. 153.

44. Idem, p. 176. O autor também comenta que o consentimento toma parte na definição de risco permitido, e que na interação entre autor e vítima é importante tentar aquilatar a atitude interna do binômio para tecer conclusões acerca do resultado delituoso.

45. BECHARA, Ana Elisa Liberatore Silva. Da teoria do bem jurídico como critério de legitimidade do direito penal, 2010, p. 179. A autora erige o consentimento como norteador da responsabilidade penal no tocante à questão da lesão ao bem jurídico, ainda que não haja expressão do consentimento no Código Penal pátrio.

46. BECHARA, Ana Elisa Liberatore Silva, op. cit., p. 180.

47. Idem, p. 180

48. Idem, p. 185. 
Em escorço histórico-doutrinário, a questão do consentimento foi dissecada por várias teorias $^{49}$. Feuerbach atribuía a capacidade de afastar o conceito de delito pelo ato de declaração da vontade do ofendido. Assim, a natureza permissiva do consentimento acabava por potencializar, por vezes de forma desmedida, o poder de disposição do titular do bem jurídico. A teoria do negócio jurídico, por sua vez, pecava por tentar transplantar um caráter privado em direitos aos quais esse tipo de natureza não se harmoniza, como a vida, liberdade e integridade física; portanto, foi repudiada como aparato jurídico. Da mesma forma, a teoria da ação jurídica também não teve aceitação na seara pública, pois considerava os bens como juridicamente tutelados se, e à medida que seu titular os considerasse como tendo valor. Edmund Mezger atribuía ao consentimento a exclusão do injusto, tendo como causas de justificação a carência de interesse ou a determinação do interesse. Finalizando a compilação de José Henrique Pierangeli, este cita Welzel, que pregava que a licitude parte da ação jurídica conformada ao consentimento, desde que esse seja inequívoco e que não haja fraude ou coação; além disso, os costumes, como fonte de direito, devem ter papel limitador no que tange à validade do consentimento.

Luiz Regis Prado elenca o consentimento do ofendido como uma das causas de justificação, ao lado do estado de necessidade, legítima defesa, estrito cumprimento de dever legal e exercício regular de direito. Mesmo assim, ressalva que "o consentimento do sujeito passivo pode excluir a tipicidade da ação ou da omissão, quando requisito intrínseco ao tipo legal, ou, eventualmente, quando externo a ele, elidir a ilicitude da conduta." ${ }^{50}$. Em determinadas circunstâncias ou situações fáticas, é mister que exista consentimento prévio ou concomitante à conduta, para que se exclua a responsabilidade penal do agente.

Como causa de justificação, é possível a aplicação do consentimento tanto em crimes dolosos como em delitos culposos. No caso de procedimentos médicos, sua eficácia dependerá da informação, pelo médico, dos detalhes do tratamento, seus riscos e possíveis efeitos deletérios ${ }^{51}$. É imprescindível observar que tal consentimento deve ser isento de vícios.

49. PIERANGELI, José Henrique. O consentimento do ofendido na teoria do delito. 2001, p. 73-80.

50. PRADO, Luiz Regis, op. cit., p. 358.

51. Idem, p. 359. 
Nessa linha, o conceito de consentimento está fortemente amalgamado com a concepção de disponibilidade dos bens jurídicos, notadamente, no caso desse estudo, do bem jurídico vida. Para Ana Elisa Bechara, ao apartar-se a transcendência e universalidade do bem jurídico e, pelo contrário, ao considerá-lo um interesse, abrem-se as portas para que a norma penal deixe de tutela-lo, eis que penalmente irrelevante ${ }^{52}$.

Isso novamente nos remete à questão da atipicidade e da causa de justificação, e, por conseguinte, ao conceito de aquiescência, termo que nasceu vocacionado para englobar o consentimento e o acordo em apenas um vocábulo ${ }^{53}$. Na verdade o termo é até mais amplo, uma vez que abarca também as situações penalmente irrelevantes, formando um tripé, ao lado da atipicidade e da causa de justificação.

Essa tríade assume evidente importância ao vislumbrarmos questões afetas à área médico-penal, com relevantes consequências práticas. Os direitos do paciente à autodeterminação e à recusa de tratamento caminham nessa trilha ${ }^{54}$. Para Pierangeli, a doutrina majoritária atual considera uma autolesão atípica, ao passo em que vislumbra tipicidade com exclusão de antijuridicidade em uma lesão que foi consentida pela vítima ${ }^{55}$. Assim, "o que torna lícita a conduta do médico, é a vontade do paciente em se submeter a um tratamento, ou, por outras palavras, é a autodeterminação do paciente em renunciar a um bem juridicamente tutelado, consciente da possibilidade de consequências lesivas a ele, consequências essas ínsitas ao tratamento",56.

A contrapartida dogmática a esse viés liberalizante seria a anulação da vontade do titular do bem jurídico em relação à sua disponibilidade, recaindo no chamado "paternalismo penal" $"$. Se acolhido, esse entendimento praticamente anularia a possibilidade da prática eutanásica voluntária, pois nem o paciente nem seus familiares poderiam dispor do bem jurídico vida. Como premissa para a eutanásia, é necessário, de início, a plena informação do paciente, ou de seus responsáveis no caso em que aquele esteja impossibilitado de fazê-lo; a seguir, deve o titular do bem jurídico expressar essa

52. BECHARA, Ana Elisa Liberatore Silva, op. cit., p. 186.

53. PIERANGELI, José Henrique, op. cit., p. 94.

54. BLAD, John R., Ceci n'est pás l'euthanasie: chronique du débat sur la mort douce aux Pays-Bas, 1991, p. 121.

55. PIERANGELI, José Henrique, op. cit., p. 102.

56. Idem, p. 201.

57. BECHARA, Ana Elisa Liberatore Silva, op. cit., pp. 188-189. O paternalismo penal, surgido na esteira do harm principle de John Stuart Mill, opõe-se à visão penal liberal, e suas intervenções "se caracterizam, de um lado, por dizerem respeito ao bem do próprio indivíduo atingido e, de outro, por conterem uma coerção, deixando de conceder à pessoa a possibilidade de repelir a medida." 
informação, de maneira clara, inteligível e sem vícios ${ }^{58}$. Ainda assim, pode-se questionar juridicamente a legitimidade do desejo de morrer, expresso em situações de sofrimento, sem nos olvidarmos, porém, que o âmbito da eutanásia transcende a situação do doente terminal que amarga dor incoercível, mas também é aventada em situações em que se perderam condições mínimas de qualidade de vida, como é o caso de pacientes com plegias incapacitantes ${ }^{59}$.

\subsection{A eutanásia e o sopesamento de bens jurídicos}

O princípio da razoabilidade, ou da proporcionalidade, permeia todo o direito, desde suas raízes constitucionais, e reza que "o bom senso, a prudência, a moderação são imprescindíveis à exegese de toda e qualquer norma constitucional" ${ }^{\prime 60}$. Certamente tal princípio é plenamente aplicável à matéria penal, em que, pela natureza da tutela e das sanções cominadas, assume particular importância. De fato, esse princípio está ínsito a toda matéria criminal, e acaba por modular e embasar sua verve garantista e de imposição restritiva, razão pela qual também é chamado de princípio da humanidade ${ }^{61}$.

O princípio da proporcionalidade assume especial relevância no que tange a temas polêmicos como aqueles afeitos à Bioética e ao Biodireito. No caso da eutanásia, tema desse capítulo, a abordagem pelo viés da razoabilidade oferece bom afinamento hermenêutico, até porque "a eutanásia não mereceu maior atenção na Constituinte"62.

Certamente o silêncio da Carta Magna se funda no tônus social da época em que foi promulgada, em que talvez o assunto não merecesse tamanho interesse. Nas duas últimas décadas, alguns casos emblemáticos, aliados à perspectiva cada vez mais próxima de as pessoas vivenciarem situações-limite relativas ao suporte avançado da vida, tem direcionado holofotes sobre a temática da eutanásia. O próprio avanço tecnológico da medicina tem colocado mais substrato nesse caldo de cultura.

O tema deixou de ser tabu, ou pelo menos é mais discutido, muito por conta da inaceitabilidade de uma moral heterônoma em sociedades mais informadas ${ }^{63}$. Nessa linha, hoje o sentido ôntico da vida é questionado, em prol de uma mudança de foco na

58. DIAS, Roberto. O direito fundamental à morte digna: uma visão constitucional da eutanásia. 2012, p. 178.

59. ASÚA, Luis Jimenez de. Liberdade de amar e direito a morrer. 2003, pp. 66 e 67.

60. BULOS, Uadi Lammêgo. Curso de direito constitucional, 2011, p. 451.

61. LIMA, Alberto Jorge Correia de Barros. Direito penal constitucional, 2012, p. 119.

62. SILVA, José Afonso. Comentário contextual à Constituição, 2010, p. 69.

63. PESSINI, L; BARCHIFONTAINE, C. P., Problemas atuais de bioética, 2008, p. 492. 
direção de outros valores ou bens, em que ressalta a dignidade da pessoa humana.

A trilha jurídica que ora se enceta leva a questionar a afirmação de que o direito protege a vida à revelia de seu titular. Pelo contrário, há um pleito social e político focado em uma maior autonomia, carreando uma possibilidade de disposição ${ }^{64}$.

É interessante, nesse matiz, a percepção de que o ser humano não tem poder sobre o início de sua própria vida, ainda que o possa ter sobre o seu fim ${ }^{65}$. Porém, sob o prisma do ordenamento jurídico, e também da ética médica, a disponibilidade da vida (ou seja, a decisão sobre o fim dela) é objeto de amplas discussões doutrinárias.

Ainda que haja vozes conservadoras, no sentido de considerar a vida como indisponível por seu titular ${ }^{66}$, a doutrina majoritária parece caminhar na linha de modular o bem jurídico vida pelo sopesamento com outros bens fundamentais, como a

64. RIVACOBA Y RIVACOBA, Manuel de. Cambio de sentido em la protección y el concepto penal de la vida humana, Doctrina Penal: Teoría y prática em las ciencias penales, 1989, p. 288. O autor elenca autores espanhóis que vão na contra-corrente dessa possibilidade de disposição da vida, assumindo posições conservadoras, como Jiménez de Asúa, Cobo Del Rosal y Vives Antón, Jiménez Huerta, Rodríguez Devesa e Muñoz Conde.

65. BARROSO, Luís Roberto. A morte como ela é: dignidade e autonomia individual no final da vida, 2010, p. 20.

66. Podemos elencar: Neri Tadeu Camara Sousa, "Ninguém, de acordo com o ordenamento jurídico brasileiro, pode dispor deste nosso patrimônio inestimável, a vida. Nós podemos usá-la e fruí-la, como bem entendermos. Mas, ninguém pode dispor dela, nem com nossa autorização ou de quem quer que seja."SOUZA, Neri Tadeu Camara. Eutanásia: aspectos jurídicos. Disponível na internet: WWW.ibccrim.org.br, 28.01.2005, p. 2. Nessa linha, também Renato Flávio Marcão, “A eutanásia e a ortotanásia não encontram fundamento nos princípios sociais e morais (...) A licença para o homicídio eutanásico deve ser repelida, principalmente, em nome do direito. Defendê-la é, sem mais nem menos, fazer apologia de um crime. Não desmoralizamos a civilização contemporânea com o preconício do homicídio. Uma existência humana, embora irremissivelmente empolgada pela dor e socialmente inútil, é sagrada. A vida de um homem até seu último momento é uma contribuição para a harmonia suprema do Universo e nenhum artifício humano, por isso mesmo, deve truncá-la. A abnegação para assistir a enfermos repugnantes, a compaixão pelos nossos próximos doentes, a simpatia por toda a criatura viva, são valores altamente úteis, aos quais não devemos renunciar. Por tudo isso, é forçoso concluir, como exclamou Morselli: "Não nos desmoralizemos"." MARCÃO, Renato Flávio. Homicídio eutanásico: eutanásia e ortotanásia no Anteprojeto do Código Penal. Disponível na internet: WWW.ibccrim.org.br, 05.06.2002, p. 3. Também nesse diapasão, Luiz Flávio Borges D’Urso, "No mundo todo existem gigantescas resistências à aprovação da lei que autoriza a eutanásia, isto porque os interesses mundanos que poderiam estar revestidos de piedade, teriam um verdadeiro salvo conduto para que o agente cometesse o crime e fosse perdoado, talvez até parabenizado por sua piedade extrema. Tenho profunda desconfiança dessas motivações, pois embora algumas delas sejam norteadas pelo sentimento de amor, muitas outras, sob essa capa estariam a esconder disputas de heranças (uma vez que enquanto não se der a morte, não se abre sucessão), ou ainda interesses conjugais subterrâneos, a encalhar o cônjuge sadio, que se vê obrigado a assistir o cônjuge enfermo, sem falar num eventual amante que aguarda-o do outro lado da porta do cômodo onde se encontra o moribundo (...) O tráfico de órgãos humanos seria a última abordagem que me leva a reiterar o risco da legalização da eutanásia, pois qualquer pessoa enferma deve ser vista como alvo de tratamento, jamais como prateleira de órgãos humanos prontos a servir quem melhor oferta fizer, mesmo que tal custe a vida daquele miserável. O mundo vem conhecendo essas máfias e a legalização da eutanásia seria um belo serviço prestado a essa modalidade de crime." D’URSO, Luiz Flávio Borges. A eutanásia no Brasil. Disponível na Internet: WWW.direitocriminal.com.br, 05.05.2001, p. 1 e 2. 
dignidade humana, destarte permitindo sua disponibilidade. É justamente aqui que se cristaliza a dificuldade da questão, já que "a pergunta quanto à maneira com que tal eutanásia pode ser harmonizada com os princípios da proteção penal à vida é especialmente difícil e complexa" ${ }^{\natural 7}$.

O teor dessa complexidade se funda no fato de, por um lado, o médico ser treinado para preservar a vida, e para isso conta atualmente com recursos tecnológicos antes impensáveis. Por outro lado, o emprego desses recursos demanda variáveis graus de sofrimento do principal interessado, que é o paciente, o que leva à dúvida sobre até que ponto o emprego dos trunfos da ciência contemporânea sejam lícitos ou dignos. Assim, pode-se eventualmente configurar o que Ferrando Mantovani nomeia de ciência trabalhando não "com" ou "pelo" homem, mas "contra" ele ${ }^{68}$. Uma abordagem interessante para esse dilema seria trabalhar com os conceitos de concepção utilitarística e de concepção personalística do ser humano. Pela primeira, o homem pode ser instrumentalizado para finalidades extra-pessoais ou de cunho coletivista, enquanto a visão personalística entende o homem como valor ético em si mesmo ${ }^{69}$. Ao vincular a abordagem personalística ao critério da indisponibilidade da vida, o autor tece considerações que se contrapõem à possibilidade da eutanásia ativa consensual. A saber: considerações principiológicas, pautadas na irrenunciabilidade da vida humana; considerações de ordem prática, devido ao risco de uma interpretação extensiva da eutanásia piedosa; e considerações de oportunidade, por conta do excessivo poder de decisão das equipes médicas, e de uma espécie de obnubilação da identidade moral e profissional do médico, focado desde sempre no ofício de salvar vidas ${ }^{70}$.

Para entendermos melhor a dinâmica desses procedimentos, e assim configurar as situações jurídicas que dele derivam, é importante esmiuçarmos o embasamento conceitual. O termo eutanásia abarca diversas situações médicas não necessariamente semelhantes entre $\mathrm{si}^{71}$, indo além do que se poderia denominar como gênero que engloba espécies. A classificação mais clássica separa a eutanásia ativa, em que ato há comissivo, da eutanásia passiva, que se pauta pela omissão de tratamento. A seguir, vieram as conceituações doutrinárias da ortotanásia e distanásia. Esses tipos de delimitação conceitual ainda hoje encontram guarida na doutrina, porém hoje

67. ROXIN, Claus. Estudos de direito penal, 2006, p. 177.

68. MANTOVANI, Ferrando. Aspetti giuridici della eutanasia, 1988, p. 450.

69. MANTOVANI, Ferrando, op. cit., pp. 450-451.

70. Idem, pp. 455-457.

71. BARROSO, Luís Roberto, op. cit., 2010, p. 22. 
comportam nuances. Luís Roberto Barroso, tendo como substrato o principialismo de Beauchamp e Childress, assim categoriza as modalidades afeitas ao tema: "a) eutanásia; b) ortotanásia; c) distanásia; d) tratamento fútil e obstinação terapêutica; e) cuidado paliativo; f) recusa de tratamento médico e limitação consentida de tratamento; g) retirada de suporte vital e não oferta de suporte vital; h) ordem de não ressuscitação ou de não reanimação; i) suicídio assistido"72.

Essas categorias elencadas ainda não revertem em clara tipificação em nosso atual ordenamento legal, excetuando-se o suicídio assistido ${ }^{73}$. Porém a eutanásia, ortotanásia e a limitação de tratamento são consideradas hipóteses de homicídio, seja na modalidade ativa ou na comissiva. O auxílio ao suicídio é tipificado no artigo 122 do Código Penal ${ }^{74}$. Consoante doutrina nacional majoritária, a eutanásia e ortotanásia poderiam ser objeto de tratamento jurídico especial somente pela via de causa especial de diminuição de pena (homicídio privilegiado $)^{75}$.

Entretanto, ainda que nosso ordenamento penal seja silente em relação a esse tipo de situação clínica, o que acaba por consignar consequências mais gravosas para o médico que lance mão de procedimentos eutanásicos, o Código de Ética Médica atual assume uma postura mais arejada. A mudança de postura médica ética começou a ocorrer a partir de 28 de novembro de 2006, com a Resolução n ${ }^{\circ} 1805$ do Conselho

72. BARROSO, Luís Roberto, op. cit., 2010, p. 22. Segundo o autor, o termo eutanásia, antes utilizado de forma genérica e ampla, hoje se circunscreve à modalidade ativa em doentes terminais, excluindo o que antes se chamava de eutanásia passiva. Distanásia se refere ao emprego inadequado e excessivo de meios terapêuticos para retardar o processo de morrer, estando ligada aos conceitos de obstinação terapêutica e de tratamento fútil; por isso alguns autores os consideram sinônimos. Ortotanásia, "em sentido oposto ao da distanásia e distinto da eutanásia", é o seguimento do curso da morte de forma harmônica, com o menor sofrimento possível por parte do paciente. Os cuidados paliativos (que hoje são especialidade médica) envolvem uso de medicamentos e procedimentos para o alívio da dor em pacientes com prognóstico fechado; é peculiar às drogas aqui utilizadas o efeito duplo, segundo o qual ocorre depressão dos sistemas vitais, em grau variado, concomitante ao alívio da dor. A recusa de tratamento médico consiste na negativa do paciente ou de seus responsáveis de iniciar uma terapia médica, e é formalizada no termo de consentimento livre e esclarecido; pode ser ampla (quando o paciente tem condições de recuperar sua saúde com o tratamento recusado), ou estrita, quando a terapêutica não tem o escopo de recuperação, havendo nesse caso laços com a eutanásia; é de se frisar que a recusa ampla é alvo de polêmica, enquanto a estrita aproxima-se da consensualidade. Fazem parte da recusa estrita de tratamento a retirada ou a não oferta de suporte vital, e as ordens de não reanimação ou não ressuscitação; nesses casos, por certo se faz necessário o consentimento do paciente ou dos responsáveis, por meio do termo de consentimento livre e informado. Por último, o suicídio assistido, que no caso da atividade médica consiste em por à disposição do paciente a forma de praticar suicídio, sendo que "o ato causador da morte é de autoria daquele que põe termo à própria vida".

73. BARROSO, Luís Roberto, op. cit., p. 27.

74. "Induzir ou instigar alguém a suicidar-se ou prestar-lhe auxílio para que o faça: Pena - reclusão, de 2 (dois) a 6 (seis) anos, se o suicídio se consuma, ou reclusão de 1 (um) a 3 (três) anos, se da tentativa de suicídio resulta lesão corporal de natureza grave".

75. Código Penal, art. 121. "Matar alguém: Pena - reclusão, de 6 (seis) anos a 20 (vinte) anos. Caso de diminuição de pena. $\S 1^{\circ}$ Se o agente comete o crime impelido por motivo de relevante valor social ou moral, ou sob o domínio de violenta emoção, logo em seguida a injusta provocação da vítima, o juiz pode reduzir a pena de $1 / 6$ (um sexto) a 1/3 (um terço). 
Federal de Medicina, que disciplina a limitação do esforço terapêutico ${ }^{76}$. O teor dessa resolução permite que o médico deixe de lançar mão ou descontinue procedimentos que retardem a morte do paciente, quando se tratar de pacientes terminais. Essa mudança de paradigma ético-profissional deu azo a que no novo Código de Ética Médica, de 2009, fosse contemplada a ortotanásia, ou melhor, desestimulada a distanásia, bem como consagrados os cuidados paliativos ${ }^{77}$. Esse novo viés ético dá maior liberdade para que o médico, com a concordância de seu paciente e/ou dos responsáveis, eleja a melhor forma de conduzir os cuidados dos pacientes terminais, indo de encontro ao princípio da dignidade humana.

Além disso, há estudiosos do tema que afastam a incompatibilidade entre a novel doutrina ética médica, do que está ora positivado no Código Penal. Ocorre que nos casos em que o prognóstico do paciente é fechado, ou seja, nos casos em que não há expectativa de vida por conta de moléstia em estado terminal, não há como penalizar o médico, já que a persistência terapêutica atentaria contra a dignidade humana ${ }^{78}$, valor, não custa lembrar, erigido a status constitucional. Nessa linha, Silva Franco lembra que a visão ôntica do bem jurídico vida "tem sofrido críticas severas por seu dogmatismo e por seu caráter nitidamente metafísico, cedendo lugar, de modo cada vez mais crescente, ao princípio da qualidade de vida",79.

Ao comparar suicídio e eutanásia, Luigi Cornacchia pontua que ambos os institutos modulam o bem jurídico vida em prol do bem jurídico liberdade individual. A solicitação de suspensão de tratamento por parte do paciente teria o condão de fazer desaparecer a obrigação do médico em permanecer tratando, sem que surja, por outro lado, a obrigação do facultativo em satisfazer o desejo do paciente. Tratar-se-ia, por conseguinte, de liberdade do médico de seguir os ditames de sua consciência ${ }^{80}$.

Nesse diapasão, deve-se ressaltar que um dos principais fundamentos da práxis eutanásica é a compaixão pelo ser humano em sofrimento, em seu sentido humanitário, e não necessariamente religioso ${ }^{81}$.

76. CARVALHO, Gisele Mendes de. Ortotanásia é eutanásia, mas não é crime (considerações a respeito da Resolução no 1.805/2006 do CFM e sua compatibilidade com o Código Penal). 2008, p. 1.

77. O artigo XXII do Capítulo I (Princípios fundamentais) do Código de Ética Médica dispõe que "Nas situações clínicas irreversíveis e terminais, o médico evitará a realização de procedimentos diagnósticos e terapêuticos desnecessários e propiciará aos pacientes sob sua atenção todos os cuidados paliativos apropriados".

78. CARVALHO, Gisele Mendes de, op. cit., p. 1.

79. FRANCO, Alberto Silva. A eutanásia passiva no novo Código Penal, 1993, p. 1.

80. CORNACCHIA, Luigi. Algunas reflexiones en torno al suicídio y la eutanasia, 2004, p. 102.

81. GARCIA, Eusebio Fernandez. Dignidad humana y eutanásia, 1999, p. 39. Discorre o autor que "La compasión, o piedad, puede ser remplazada también por sinonimos como humanidad, conmiseración o 
A concepção de sofrimento, por sua vez, está intimamente ligada, pelo seu oposto, ao princípio da dignidade da pessoa humana, este visando evitar a concretização daquele em vários âmbitos, desde o físico até o emocional e psíquico. Não deve caber ao Estado apartar a capacidade de disposição que o ser humano tem em relação à sua própria vida, parecendo patente que a dogmática moderna enxerga o problema sob outro olhar, tendo como sustentação a tutela da dignidade humana ${ }^{82}$. Em breve incursão ao direito comparado, vê-se que o direito espanhol respalda a recusa ao tratamento desde 1986, estendendo essa disponibilidade aos parentes do paciente em casos em que este se encontre impossibilitado de se expressar. Ao contemplar essa prerrogativa do paciente, a legislação espanhola elege como fulcro a dignidade da pessoa humana, entendendo o ser humano como titular da qualidade de ser um fim em si mesmo. Por conta dessa titularidade, e como consequência dela, floresce, como sua essência, a característica volitiva ${ }^{83}$. Manuel Rivacoba entende que, sem esquecer o bem jurídico vida, cabe uma comparação valorativa de bens jurídicos no que tange ao problema da eutanásia $^{84}$.

Destarte, ainda que o peso do bem jurídico vida seja aferível com vigor, no outro prato se coloca a dignidade da pessoa humana, cuja valoração bebe na fonte da própria Carta Magna (art. $1^{\circ}$, III), onde é alçada a fundamento da República. Decorre daí a legitimidade do Estado na promoção dessa dignidade, e também seu entendimento

misericordia. En todos esos casos, lo que se encuentra detrás es la idea de un sentimiento o afecto que lleva a compadecerse por la desgracia del otro.(...) La piedad o sentimiento compasivo surge como respuesta a una desgracia ajena y visible, como la comunicación de un curioso mecanismo que sentimos frente al dolor de los otros y que se ha dado el nombre de simpatía."

82. RIVACOBA Y RIVACOBA, Manuel de, op. cit., p. 290.

83. Idem, p. 291.

84. Idem, p. 294. A esse respeito, o autor expressa que "Se plantea, así, un problema mucho más amplio y sugestivo, que excede los límites de cualquier rama del árbol jurídico, pero que al cabo de las presentes paginas no cabe sino apuntar: el de si todos los conceptos que utiliza el derecho, aun los más sencillos y que estén tomados directamente de la realidad natural o social, no implican, por el hecho de servirse de ellos, una cierta elección y matización, esto es, una cierta valoración, bien que no sea más que primaria y elemental, siendo, por tanto, de índole normativa." Nesse sentido, também BARROSO, Luís Roberto, $A$ morte como ela é: dignidade e autonomia individual no final da vida, 2010, p. 33: "É precisamente no ambiente da morte com intervenção que cabe discutir a visão da dignidade que impõe ao indivíduo a vida como um bem em si. Como intuitivo, não se está aqui diante de uma situação banal, temporária ou reversível, na qual um indivíduo decide morrer e outros se omitem em evitar ou prestam-lhe auxílio. Justamente ao contrário, trata-se de pessoas que, em condições nada ordinárias, reclamam a possibilidade de renunciar a intervenções médicas de prolongamento da vida. Ou, em outros casos, de optar pela abreviação direta da vida, por ato próprio ou alheio, por estarem acometidos de doenças terminais extremamente dolorosas ou por enfermidades degenerativas que conduzem à perda paulatina da independência. Nessas situações extremas, aparecem outros direitos e interesses que competem com o direito à vida, impedindo que ele se transforme em um insuportável dever à vida. Se, em uma infinidade de situações, a dignidade é o fundamento da valorização da vida, na morte com intervenção as motivações se invertem." (grifo nosso) 
como norteador hermenêutico de nosso ordenamento jurídico ${ }^{85}$.

De fato, ao lado da valoração da vida como direito fundamental, a

Constituição brasileira também elenca a liberdade, igualdade, segurança e propriedade $^{86}$. Desse rol, interessa ao estudo jurídico da eutanásia os valores da vida e da liberdade, permeados pelo princípio da dignidade da pessoa humana.

Nesse sentido, Vicente Greco Filho ensina que a tutela constitucional dos direitos perpassa pelos direitos fundamentais da pessoa humana, situando-os em uma posição acima do Estado, e, por conseguinte, garantindo-os ${ }^{87}$. Cabe ao direito disciplinar os direitos contrapostos, "determinando, em cada caso, qual deve prevalecer, qual deve ser satisfeito" $" 88$.

Sob esse prisma, ao analisar a questão da eutanásia é importante ter como bissetriz o sopesamento do bem jurídico vida e do bem jurídico dignidade da pessoa humana. Ao deslindar esses bens, que também poderiam ser chamados de valores, podemos aquilatar se, e em quais casos, a eutanásia pode ser permitida. Importa perceber que nas situações clínicas envolvendo a possibilidade da eutanásia, tal balanceamento ocorre quase de forma intuitiva ou informal, com base na análise fática do caso concreto ${ }^{89}$. Isto sói ocorrer justamente porque tem existido, de forma crescente, uma aceitação social das situações de eutanásia, com o intuito de minimizar o sofrimento do paciente terminal, mormente nos casos classificados como ortotanásia ${ }^{90}$.

Nem é de se estranhar essa moderna postura liberalizante, vez que caminha na trilha do direito de autonomia do paciente, que tem se tornado mais cristalizado no ordenamento ético-médico e também, ainda que com atraso, no próprio ordenamento jurídico brasileiro. Em algumas normatizações alienígenas esse viés já está mais sedimentado; nos Estados Unidos, por exemplo, a "common law" respalda a livre disposição do corpo. Assim, o paciente teria garantida sua intimidade, liberdade e

85. BARROSO, Luís Roberto, op. cit., p. 36.

86. SILVA, José Afonso da, op. cit., p. 57.

87. GRECO FILHO, Vicente. Manual de processo penal, 2010, p. 11. Nesse diapasão, com pequena incursão na zetética jurídica, vale também lembrar a lição de Tércio Sampaio FERRAZ JR, “...o problema do direito natural está por detrás de muitas preocupações da ciência dogmática do direito, por exemplo, na sua tentativa de encontrar-lhe substitutos, isto é, princípios para-universais e para-consistentes, como o da legalidade, o do interesse público relevante, o da autonomia privada, o da responsabilidade fundada na liberdade, etc. Tais princípios que, no âmbito dogmático, trazem, às vezes oculta, às vezes patentemente, a marca da relatividade, revelam, no fundo, a inquietação angustiosa do jurista contemporâneo.", Introdução ao estudo do direito, 1996, p. 172.

88. GRECO FILHO, Vicente, op. cit., p. 9.

89. GUIMARÃES, Marcello Ovídio Lopes. Eutanásia: novas considerações penais. 2011, p. 210.

90. GUIMARÃES, Marcello Ovídio Lopes, op. cit., p. 214. 
autonomia, o que em última análise ensejaria a possibilidade da eutanásia ${ }^{91}$.

Rematando essa discussão e perscrutando o plano ético, que nessa seara é o pano de fundo do bem jurídico, vê-se que problemática da inviolabilidade da vida caminha entre duas trilhas. Por um lado, há quem veja o homem como mero administrador de sua vida, não podendo dispor dela. Por outro, há quem reconheça no homem a autodeterminação, delegando a ele a capacidade de disposição de sua própria existência ${ }^{92}$. Pessini e Barchifontaine comentam que a primeira visão poderia levar ao vitalismo físico, segundo o qual a manutenção da vida suplantaria a possibilidade de equipará-la com valores como autonomia e dignidade. A segunda doutrina, por sua vez, caracterizaria o utilitarismo pessimista, em que a vida seria considerada um fardo se não tivesse utilidade social. Peter Singer, por seu turno, entende que "a objeção utilitarista clássica não se aplica à eliminação que só se verifica com o consentimento concreto da pessoa eliminada"93. Para o filósofo australiano, favorável à eutanásia nas situações de grave comprometimento da qualidade de vida, o direito à vida, como todo direito, é algo de que se pode dispor ${ }^{94}$.

Talvez seja de valia, no sopesamento dos bens jurídicos aqui envolvidos, a percepção de que há "realidades que precisam ser matizadas, principalmente nesse contexto de final de vida em que a presença da dor e do sofrimento são uma constante" ${ }^{, 95}$. Também não se pode prescindir, por certo, do ferramental principiológico, assunto do próximo capítulo desse estudo.

91. GUIMARÃES, Marcello Ovídio Lopes, op. cit., p. 215.

92. PESSINI, Leocir; BARCHIFONTAINE, Christian de Paul. Problemas atuais de bioética, 2008, p. 551.

93. SINGER, Peter. Ética prática, 2002, p. 204.

94. "O utilitarismo preferencial também sugere uma posição favorável, e não contrária, à eutanásia voluntária. Assim como o utilitarismo preferencial deve levar em conta o desejo de continuar vivendo como uma das razões contra tirar a vida, é preciso que leve em conta o desejo de morrer como uma das razões para tirá-la." SINGER, Peter, op. cit., pp. 204-205.

95. PESSINI, Leocir; BARCHIFONTAINE, Christian de Paul, op. cit., p. 553. 


\section{CAPÍTULO IV. PRINCÍPIOS DA DIGNIDADE HUMANA E DA RAZOABILIDADE}

\section{Dignidade humana}

Parece consensual, no estudo da história do direito, que o princípio da dignidade da pessoa humana teve sua gênese nas Revoluções Americana e Francesa, no século XVIII $^{96}$. Certamente os conceitos que fomentaram estes movimentos vem de antes, tendo uma base humanista greco-romana, porém não cabe esmiuçá-los neste breve estudo. Fato é que a essência das revoluções foi a busca da tríade felicidade, liberdade e igualdade, com alguma diferença de vieses: enquanto a revolução francesa dava certa ênfase à questão da igualdade, entendida como "felicidade comum", a americana tinha como seu fulcro a liberdade ${ }^{97}$. Kant, na Alemanha, absorve os valores liberais na formulação de sua fillosofia ${ }^{98}$, e os utiliza como pilares ao entender o homem como um fim em si mesmo.

Em sede constitucional brasileira, entende-se que a Carta Magna, ao elencar a dignidade da pessoa humana como um de seus fundamentos, em seu artigo $1^{\circ}$ III, precisamente reconhece este valor em um sentido apriorístico ${ }^{99}$. Ou seja, além do fato de esse princípio ser explicitado logo no artigo que abre a Constituição, o documento, "reconhecendo sua existência e sua eminência, transformou-a num valor supremo da ordem jurídica, quando a declara como um dos fundamentos da República Federativa do Brasil constituída em Estado Democrático de Direito" ${ }^{\text {100 }}$. Em apertada síntese, a essência desse princípio condensa os direitos e garantias fundamentais expressos na Constituição, ao tutelar "o espaço de integridade moral do ser humano, independentemente de credo, raça, cor, origem ou status social"101. Interessa ressaltar, nesse ponto, que a dignidade da pessoa humana se consubstancia em um verdadeiro "sobreprincípio", que pode permear a leitura exegética de toda a Constituição da República $^{102}$.

96. BILLIER, Jean-Cassien; MARYIOLI, Aglaé. História da filosofia do direito, 2005, p. 166.

97. BILLIER, Jean-Cassien; MARYIOLI, Aglaé, op. cit., p. 168.

98. MASCARO, Alysson Leandro. Filosofia do direito, 2010, p. 206.

99. SILVA, José Afonso da. Comentário contextual à Constituição, 2010, p. 40 e 41. Comenta o professor que "a dignidade da pessoa humana reclama condições mínimas de existência, existência digna conforme os ditames da justiça social como fim da ordem econômica".

100. SILVA, José Afonso da, op. cit., p. 40.

101. BULOS, Uadi Lammêgo. Curso de direito constitucional, 2011, p. 502.

102. BULOS, Uadi Lammêgo, op. cit., p. 502. Alexandre de Moraes complementa essa ideia, ao atribuir uma ideia de unidade ao princípio da dignidade da pessoa humana em face dos direitos e garantias fundamentais. MORAES, Alexandre de, Direito constitucional, 2001, p. 48. 
Ao ter a capacidade de matizar e entremear os outros princípios, a dignidade da pessoa humana exerce um verdadeiro efeito irradiante, norteando toda a interpretação do texto constitucional ${ }^{103}$. Por conseguinte, acaba por sujeitar o legislador e o juiz a suas diretivas, servindo de verdadeiro ponto de partida, particularmente em sede de direito penal $^{104}$.

Entretanto, causa certa espécie perceber que um instituto de tamanha repercussão jurídica possa ser dotado de flagrante vagueza quando se pensa em sua definição. Em torno do instituto acumulam-se discursos que modificam seus $\operatorname{contornos}^{105} \mathrm{e}$, mais do que isso, dotam-no de evidente ambivalência ${ }^{106}$. Nesse sentido, Ingo Sarlet, reportando-se a Michael Sachs, comenta que a dificuldade na especificação do conceito de dignidade humana parte justamente da sua imanência a todo ser humano, sendo, portanto, apartado de uma definição de mais fácil compreensão, como integridade física, propriedade ou intimidade ${ }^{107}$. É justamente com fulcro nessa imanência e inerência que Marie-Luce Pavia evoca o termo elegantemente sintético de Bernard Edelman, que acopla a dignidade humana ao que "existe de humano dentro do homem" $" 108$.

Fato é que, independentemente de preocupações conceituais, ou pelo contrário até pela sua vasta largueza, o uso jurídico do princípio da dignidade da pessoa humana estende suas asas sobre uma gama ampla de situações fáticas. Ao aninhar um elemento objetivo, que é o mínimo existencial do ser humano, e um subjetivo (respeitabilidade e autoestima $)^{109}$, oferece um embasamento quase que onipresente ao jurista, o que justifica o uso por vezes inadequado ou excessivo do princípio.

103. LIMA, Alberto Jorge Correia de Barros. Direito penal constitucional, 2012, p. 33.

104. LIMA, Alberto Jorge Correia de Barros, op. cit., p. 31. Nessa linha, também Luiz Regis Prado: "a força normativa desse princípio supremo se esparge por toda a ordem jurídica e serve de alicerce aos demais princípios penais fundamentais. Desse modo, por exemplo, uma transgressão aos princípios da legalidade ou da culpabilidade implicará também, em última instância, uma lesão ao princípio constitucional da dignidade da pessoa humana." PRADO, Luiz Regis, Curso de direito penal brasileiro, 2008, p. 135.

105. PAVIA, Marie-Luce. La découverte de la dignité de la personne humaine, 1999, p. 3.

106. PAVIA, Marie-Luce, op. cit., p. 4. “...Mais la découverte est ambivalente, elle est à la fois enregistrement d'une tradition et réinterpretation. Autrement dit, parce qu'il s'agit des droits de l'homme, qui son porteurs d'une dimension éthique, le sens juridique de la dignité de la personne humaine ne peut être totalement inventé, sans faire référénce à une valeur déjà nommée et dejà vécue. Cette dernière est, em quelque sorte, filtrée par le droit, dont le role est de la faire vivre dans situations effectives qui, elles, relevent du droit positif."

107. SARLET, Ingo Wolfgang. Dignidade da pessoa humana e direitos fundamentais na Constituição de 1988, 2002, p. 39.

108. PAVIA, Marie Luce, op. cit., p. 7.

109. NUCCI, Guilherme de Souza. Manual de direito penal, 2012, p. 86. 
Por conta disso, com intuitos delineadores, Helena Costa, reportando-se a classificação de Humberto Ávila, coloca a dignidade humana sob três vieses, no que tange ao direito penal: como fundamento jurídico, como postulado normativo e como princípio $^{110}$.

Nesse sentido, enxergando o direito penal como uma garantia da pessoa em face do aparato punitivo estatal, a dignidade humana se insere como fundamento. Isso se coaduna com o fato de que o direito penal, por carrear as mais gravosas sanções jurídicas, deve ter a preocupação com a dignidade humana como foco inolvidável.

Em sua faceta de postulado normativo, a dignidade humana oferece uma ferramenta hermenêutica tanto em sede material como no plano processual. Ao funcionarem como metanormas, ou seja, "normas que estruturam a maneira pela qual outras normas devem ser aplicadas" ${ }^{\text {111 }}$, os postulados normativos podem modificar o âmbito de aplicação das normas de direitos fundamentais.

Por fim, como princípio, o instituto atua como elemento prescritivo de comportamentos protetores em relação à pessoa humana. Aqui, o aparato principiológico se estende aos direitos fundamentais, notadamente "vida, integridade física e psíquica, liberdade, o respeito e garantia de condições mínimas de vida, a autonomia, a igualdade"112. Vale frisar que a pessoa humana representa a verdadeira razão da existência do direito, ou seja, a pessoa é o objeto do direito, e por isso o valor da pessoa humana antecede, condiciona e justifica o direito positivo ${ }^{113}$.

Dito isso, cabe agora rematar a discussão que foi tangenciada no capítulo anterior, no sentido de situar os procedimentos médico-científicos dentro do caminho pavimentado pela dignidade humana. Esse valor, por certo, se estende sobre tudo que concerne à biotecnologia, tendo base constitucional ${ }^{114}$. Ao erigir a dignidade humana

110. COSTA, Helena Regina Lobo da. A dignidade humana: teorias de prevenção geral positiva, 2008, p. 59 e ss.

111. COSTA, Helena Regina Lobo da, op. cit., p. 36.

112. Idem, p. 56. A esse respeito, José Ascensão ensina que a dignidade é inerente à pessoa, e que os direitos humanos tem, todos eles, como embasamento essa dignidade. Esta, por sua vez, provém da "capacidade de auto-realização da personalidade". ASCENÇÃO, José Oliveira. A dignidade da pessoa e o fundamento dos direitos humanos. In: Revista Mestrado em Direito: direitos humanos fundamentais, n. 2, v. 11, 2008, p. 99.

113. GRECO FILHO, Vicente; GRECO, Alessandra Orcesi Pedro. A prova penal no contexto da dignidade da pessoa humana. In: MIRANDA, Jorge; SILVA, Marco Antônio Marques da (coord.). Tratado luso-brasileiro da dignidade humana, 2009, p. 990.

114. FAGUNDES JÚNIOR, José Cabral Pereira. Limites da ciência e o respeito à dignidade humana. In: SANTOS, Maria Celeste dos (coord.). Biodireito: ciência da vida, os novos desafios, 2001, p. 282. 
como verdadeiro "imperativo constitucional", insculpido no artigo $1^{\circ}$, inciso III, da Lei Maior, o legislador tece uma perspectiva que tem até mesmo reflexos hermenêuticos ${ }^{115}$. Tal postura, por sinal, não é apanágio da Constituição Federal brasileira, mas também está inculcada nas Cartas de Portugal e da Alemanha, como exemplifica José de Oliveira Ascenção ${ }^{116}$. Segundo o catedrático lusitano, a pessoa é "o ente ou a substância que tem e manifesta aquela dignidade", o que gera, por óbvio, consequências em todo o ordenamento jurídico, já que a pessoa passa a ser protagonista em toda análise legal ${ }^{117}$.

Lapidando essa matéria no terreno do Biodireito, Beristain vai além do foco constitucional, invocando a bioética como verdadeira amálgama entre a ética civil e a religiosa, e dando a ela um prisma jurídico renovador, caminho talvez antes não explorado no âmbito dessa novel ciência ${ }^{118}$. O autor sugere uma forma diferente de abordar as questões bioéticas, enxergando-as de uma perspectiva "nova, mais humana, mais tolerante, mais solidária, mais global e mais lúdica" ${ }^{119}$.

Não se deve esquecer o aspecto do custo das tecnologias médicas e até que ponto isto pode influenciar as questões biojurídicas, levando em consideração, como ensina o direito econômico, que os recursos são finitos, e que devem ser direcionados de forma racional, tendo como fulcro a própria dignidade humana vista sob um aspecto social. Para Beristain, esse enfoque parece obedecer menos a limitações de custo e mais à vontade do paciente, que em regra deve se eximir do estigma de ser "propriedade" do médico $^{120}$.

115. DANTAS, Ivo; ARAÚJO, Ionnara Vieira de. Dignidade da pessoa humana e bioética. In: Revista da Faculdade de Direito da UFG, n. 32, v. 32, 2008, p. 92. Os autores lembram que o modelo constitucional atual não se coadunaria com uma diretriz sintética ou concisa, eis que a Carta Magna teve que regular novos direitos, dentre os quais os valores atinentes ao Biodireito. Isso, por sua vez, levou, direta ou indiretamente, a um processo de "juridicização da bioética".

116. A dignidade da pessoa e o fundamento dos direitos humanos. In: Revista Mestrado em Direito: direitos humanos fundamentais, n. 2, v. 11, 2008, p. 83-84: "Não são casos isolados. Os apelos à dignidade da pessoa humana multiplicam-se nas constituições, como fundamento geral. Inspiram-se todos no modelo paradigmático da Grundgesetz alemã, sem nunca atingirem, todavia, a grandeza lapidar desta: "Die Würde des Menschen ist unantasbar" (a dignidade da pessoa humana é inviolável). Abre a própria Constituição, separada de todo o resto, pois tudo o mais surge como concretização desta grande premissa."

117. ASCENÇÃO, José de Oliveira, op. cit., p. 84.

118. BERISTAIN, Antonio. Bioetica y nuevos deberes: derechos humanos. In: Revista Brasileira de Ciências Criminais, n. 13, v. 4, 1996, p. 22. “(...) la bioetica constituye hoy el nuevo rostro de la etica científica y que facilita la convergencia de la etica civil con la religiosa, sino que además nos motiva a los juristas, criminólogos y victimólogos para formular nuevos derechos humanos (y a los teólogos para renovar las ciencias del conocimiento de Dios y las que regulan nuestras relaciones interpersonales)."

119. Idem, p. 26.

120. Idem, p. 29. 
No plano ético, entendendo a dignidade humana como aspecto inerente a todo ser humano, fica evidente a ideia de sopesamento que deve permear o confronto entre esta dignidade e a vida. Como nem sempre ambos os valores caminham no mesmo sentido, e em muitos casos estão em vias inversas, há que se ter um norte valorativo para escolher qual o sentido correto. Tudo permeado pela autonomia, derivada, ela própria, da dignidade humana. O reflexo imediato desse tirocínio é a possibilidade da eutanásia, hoje erigida a ringue jurídico no balanço entre aqueles valores ${ }^{121}$.

A questão, porém, envolve certas particularidades que não podem passar despercebidas para o pesquisador do tema. Exemplo disso é que nem sempre a simples suspensão do suporte à vida, em ato omissivo, concorre para o cuidado com a dignidade humana. Isso porque, a depender da situação clínica do paciente, a mera descontinuidade da administração de medicamentos e/ou alimentação enteral, parenteral ou hidratação, não concomitante a medidas analgésicas e sedativas, pode atentar contra a dignidade do paciente, na medida exata de seu desconforto. Inclui-se aqui, também, a necessidade de assistência espiritual ${ }^{122}$.

Nesse diapasão, não se trata aqui de fazer uma escolha. Parece cada vez mais pacífico na doutrina que a tutela da dignidade humana deve se estender também ao processo de morrer, no sentido de prover dignidade e conforto ao moribundo. Ou seja, a dignidade humana deve acompanhar toda a vida da pessoa, incluindo a iminência de seu término. Dito de outra forma, ao invés de uma opção por valores, deve haver uma harmonização entre eles ${ }^{123}$.

121. Nessa linha: “(...) têm-se entre os direitos da personalidade alguns que podem ser suprimidos em virtude do exercício de outro mais valioso, situação em que deve ser conferida ao homem a opção de escolher o de mais alto valor, de acordo com sua própria vontade e concepção de vida, no exercício consciente de sua autonomia. Ainda que alguns desses direitos em questão se refiram à saúde, ao socorro médico, à sobrevivência artificial, à expressão do próprio pensamento e, até mesmo, à morte. A imposição de sobreviver em um leito de morte obsta o exercício da vontade humana, cerceia a liberdade e a autonomia da pessoa. Ela própria é quem deve deliberar sobre sua vida, seu destino, seu futuro. Ela mesma, e só ela, frise-se, é quem sabe qual é o melhor caminho para si." CABRAL, Hildeliza Lacerda Tinoco Boechat. Eutanásia: dignidade da pessoa humana como fundamento ético e jurídico do direito à morte digna. In: Revista Magister de Direito Penal e Processual Penal, n. 43, v. 8, 2011, p. 62.

122. A esse respeito: FURNARI, Marianna Gensabella. Alle frontiere della vita. Eutanasia ed etica del morire, 2003, p. 59. "Ho ricordato che esiste un consenso unanime sull'idea che in certi casi è lecito non insistire nel voler prolungare ad ogni costo la vita. Tuttavia, fermarsi non può certo significare solo "staccare la spina" o lasciare, come si suol dire, che "la natura faccia suo corso". Spesso purtroppo la natura non coopera e il suo corso normale si traduce in ulteriori tormenti per il paziente: non sempre, infatti, la sospensione dei trattamenti conduce a una morte rapida (...)"

123. FURNARI, Marianna Gensabella, op. cit., p. 62: "Con "diritto di morire con dignità" ci si intende riferire al diritto di vivere anche le fasi terminali dell'esistenza in condizioni e con modalità che non arrechino offesa alla dignità delle persone; insomma, non alla rivendicazione di un nuovo diritto, ma alla rivendicazione del rispetto di una intrinseca dimensione dello stesso diritto di vivere con dignità tutte le fasi dell'esistenza umana." 


\section{Razoabilidade}

O princípio da razoabilidade emergiu de um substrato de natureza econômica. O direito moderno fomentou a razoabilidade pela necessidade de regular o adequado fluxo de mercadorias, dentro de um status comercial liberal. Nesse sentido, a antiga equidade, por conta da profusão mercantil, deu azo a uma busca por um sistema de normas que, ao assegurar a "calculabilidade exigida pelas transações econômicas" 124, garantiu segurança e confiabilidade ao aparato comercial. A regra da razoabilidade veio na esteira de uma legislação antitruste.

Em sede legal, Eros Grau ensina que a norma possui sempre um escopo geral, expresso em seu enunciado. A partir disso, o operador jurídico deve suprir a inevitável omissão, pelo atributo da generalidade, do legislador, e preencher a lacuna para que haja real aplicação ao caso ${ }^{125}$. Assim, a razoabilidade, ou proporcionalidade, é um desdobramento da própria equidade. Ao ser moldada para ter aplicabilidade prática, a norma jurídica leva a uma norma de decisão; a primeira, derivada de uma interpretação in abstracto, utiliza uma operação de subsunção. A segunda, derivada da norma jurídica, se municia de uma interpretação in concreto, e com aquela não se confunde porque penetra no terreno da aplicação ${ }^{126}$. Grau sustenta que, na teoria silogística que enxerga a norma abstrata como premissa maior, e a aplicação ao caso concreto e consequência jurídica como premissa menor, a razoabilidade atua no momento da aplicação $^{127}$.

Pode-se ponderar, de forma abrangente, que a razoabilidade tem suas raízes no "bom senso jurídico", entendido como uma saída lógica para que o espírito das normas possa suplantar a deturpação formalista advinda da mera letra legal. Ou seja, a razoabilidade é "uma orientação que se contrapõe ao formalismo vazio, à mera observância dos aspectos exteriores da lei, formalismo esse que descaracteriza o sentido finalístico do direito" ${ }^{128}$.

124. GRAU, Eros Roberto. Equidade, razoabilidade e proporcionalidade. In: Revista do advogado, n. 78, V. 24, 2004, p. 27.

125. “(...) sabemos que a interpretação é constitutiva - não meramente declaratória -, que a norma é produzida pelo intérprete e que interpretar o direito é caminhar de um ponto a outro, do universal ao singular, através do particular, conferindo a carga de contingencialidade que faltava para tornar plenamente contingencial o singular." GRAU, Eros, op. cit., p. 28.

126. Idem, p. 29.

127. Idem, p. 30.

128. BUCCI, Maria Paula Dallari. O princípio da razoabilidade em apoio à legalidade. In: Cadernos de direito constitucional e ciência política, v. 4, n. 16, 1996, p. 173. 
Nessa linha, a razoabilidade, ao se configurar como um critério subsidiário de interpretação das normas, desagua em "condição necessária, mas não suficiente para a validade dos atos emanados do Poder Público" ${ }^{129}$. Além disso, o direito administrativo ensina que a razoabilidade, ao se contrapor ao princípio da legalidade, pode servir de instrumento protetivo para a o cidadão em face do Estado, e também para a concretização do justo ${ }^{130}$. O que, diga-se, pode ser doutrina muito bem-vinda em sede de direito criminal.

Entretanto, a razoabilidade também pode estender suas asas ao próprio controle abstrato da norma. Isso porque, por força da supremacia hierárquica da Constituição, esse deve ser o norte teleológico de toda a legislação infraconstitucional. Ou seja, o filtro para se analisar a lei deve ser seu efeito na realidade fática, inescapável da diretriz constitucional, e para isso a razoabilidade pode ser um bom armamento modulador ${ }^{131}$.

Inserida nessa discussão, há frequente dúvida doutrinário-terminológica acerca dos vocábulos razoabilidade e proporcionalidade. Parte da doutrina os considera sinônimos. Elival Ramos, para esclarecer a questão, pontua que a origem dos dois termos jurídicos é diferente. A razoabilidade provém do direito norte-americano, e tem como essência não só servir de parâmetro racional para a solução de casos concretos, mas também funcionar como "controle finalístico da legislação", mitigando excessos, inadequações e desbalanços teleológicos ${ }^{132}$.

O termo proporcionalidade, por sua vez, bebe das fontes germânicas, e se desdobra nos conhecidos conceitos de adequação, necessidade e proporcionalidade em sentido estrito. O problema, na opinião do mestre constitucionalista, é que não há paridade doutrinária possível em face do sistema jurídico brasileiro, eis que na Alemanha a proporcionalidade, de menor plasticidade em relação à razoabilidade, serve de instrumento de controle de constitucionalidade em face de normas restritivas de

129. BUCCI, Maria Paula Dallari, op. cit., p. 173.

130. Idem, p. 174.

131. RAMOS, Elival da Silva. A exigência da proporcionalidade no controle abstrato de normas brasileiro. In: Revista Mestrado em Direito: direitos humanos fundamentais, n. 1, v. 14, 2010, p. 120. "Muitas vezes o que se tem em vista é a norma-matriz da garantia da proporcionalidade legislativa, derivada da exigência de que a legislação restritiva de direitos fundamentais observe o devido processo legal; em outras situações, trabalha-se com mero postulado hermenêutico, a orientar o intérprete-aplicador na fiscalização da constitucionalidade de leis que busquem harmonizar normas finalísticas de incidência simultânea e, por isso mesmo, aparentemente colidentes; por último, há o uso, já mencionado, da proporcionalidade enquanto modo peculiar de controle da constitucionalidade de leis e atos normativos, tendo em vista o pleno acatamento dos fins que a Constituição impõe ao legislador."

132. RAMOS, Elival da Silva, op. cit., p. 124-125. 
direitos fundamentais de liberdade e propriedade, o que torna a aplicação do conceito bem mais pontual e especializada. Destarte, não seria possível a mera transposição do termo, em sua acepção alemã, para o ordenamento jurídico pátrio, já que há substanciais diferenças na amplitude de utilização do instituto entre os dois países ${ }^{133}$. No entanto, o mesmo autor mitiga a crítica ao admitir que “(...) no sistema de controle brasileiro, entre os postulados da proporcionalidade e da razoabilidade existe uma parcial coincidência, sendo o segundo mais amplo que o primeiro, permitindo-lhe total correspondência com as modalidades já identificadas de inconstitucionalidade finalística"134.

No âmbito criminal, Hassemer disserta sobre a íntima e necessária relação que deve haver entre o direito penal material e o processual, no sentido de que "o processo penal nada mais é do que uma correia transportadora do direito penal material para a

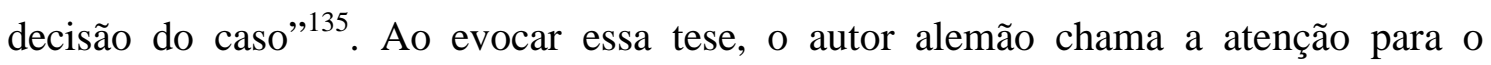
princípio da legalidade, cuja efetividade depende de um correto manejo processual, e também, no que nos interessa para este breve estudo, para a razoabilidade. A aplicação dotada de razoabilidade, para Hassemer, está profundamente imiscuída na questão da oportunidade. Nesse sentido, a clássica concepção positivista, que aplica o direito penal de forma excessivamente legalista e monocórdica, pode levar a afeitos deletérios. Ao revés, a "interpretação razoável da lei" "136, adaptada às várias situações fáticas que a norma abstrata não consegue prever na situação concreta, gera melhores frutos não só no resultado do processo, mas também na própria política criminal.

Ainda no plano penal, em obra dedicada ao tema da proporcionalidade, Mariângela Gomes argumenta que o montante da sanção reflete a importância que o legislador dá ao bem jurídico protegido. A pena cominada, porém, ainda que tutele bens jurídicos definidos na Carta Magna, não possui um fundamento constitucional, eis que "é sabido que o texto constitucional não dispõe, ao menos explicitamente, sobre eventual hierarquia entre eles" ${ }^{\prime 137}$.

133. Elival Ramos assim arremata a questão: “(...) Não se questiona que o Direito Comparado, dentre outras serventias, pode ser extremamente útil à compreensão do direito nacional. Entretanto, a importação de categorias doutrinárias alienígenas deve ser feita de modo extremamente criterioso. Não basta a verificação da compatibilidade da construção teórica com o ordenamento jurídico nacional: faz-se necessário perquirir de sua funcionalidade, isto é, se contribui do modo mais eficiente possível para a sistematização do direito pátrio.” Op. cit., p. 126.

134. Idem, p. 129.

135. HASSEMER, Winfried. Direito penal libertário,2007, p. 51.

136. Idem, p. 59.

137. GOMES, Mariângela Gama de Magalhães. O princípio da proporcionalidade no direito penal, 2003, p. 157. 
Em sede filosófica, por sua vez, a razoabilidade integra uma das cinco variáveis da autonomia, juntamente com o autoconhecimento, inteligência, eficácia e unidade. Dentro dessa complexidade, a razoabilidade dota a autonomia da capacidade de fazer avaliações objetivas no deparo com uma ou mais hipóteses ${ }^{138}$. Nesse sentido, relacionase de perto com a definição de racionalidade, e "marca a motivação de alguém que satisfaz o modelo histórico filosófico" desse último conceito ${ }^{139}$. Por certo as variáveis acima mencionadas não são estanques, já que a possibilidade de fazer escolhas racionais depende, $e . g$., do autoconhecimento, e também da inteligência que permita à pessoa uma adequada percepção do mundo que a rodeia. Na busca por imparcialidade, ideal da razoabilidade, a pessoa reconhece, porém, que essa percepção é limitada ${ }^{140}$. Ao fim e ao cabo, cristaliza-se o exercício da autonomia, tema que abrirá o próximo capítulo deste estudo.

138. DOUBLE, Richard. The non-reality of free will, 1991, p. 38.

139. DOUBLE, Richard, op. cit., p. 41.

140. “(..) The reasonable person wishes to evaluate evidence for and against preexisting beliefs impartially. Reasonability seeks fairness in evaluating evidence that conflicts with one's beliefs: the person whose behavior is motivated by reasonability can be "reasoned with" and won't appeal to the "informal fallacies", e.g., argumentation ad hominem, ad baculum, and appeal to authority, which reveal a lack of respect for reason.” Idem, p. 42. 


\section{CAPÍTULO V. ABORDAGEM DOUTRINÁRIA E BIOÉTICA}

\section{A questão da autonomia}

As diretivas antecipadas de vontade para o fim da vida são espécie do gênero das diretivas antecipadas de vontade. Estas últimas surgem na esteira da solidificação do consentimento, sobre o qual já foi discorrido neste estudo, e em particular do consentimento na seara da relação médico-paciente.

É fato que atualmente o consentimento informado perpassa toda a relação entre o paciente/cliente e as equipes de saúde nos países civilizados ${ }^{141}$. Essa realidade decorre da cabal consagração do princípio da autonomia no moderno diálogo entre o médico e seu cliente, e também estende suas asas à própria pesquisa médica ${ }^{142}$.

\subsection{Autonomia como teoria geral}

Vista sob a ótica da teoria geral do direito, a autonomia, para Norberto Bobbio, deve ser diferenciada da heteronomia, no sentido em que na primeira o formulador da norma e aquele que a segue são a mesma pessoa. Na heteronomia, por sua vez, o criador da norma a impõe para que outra pessoa a siga ${ }^{143}$. Bobbio, reportando-se a Kant, destaca que essa delimitação, em verdade, pode representar a diferença entre norma moral (autonomia) e norma legal (heteronomia), já que no caso da autonomia a pessoa que segue a norma age dentro dos liames de sua própria consciência ${ }^{144}$. Porém, lembra

141. GONZÁLEZ, Miguel Ángel Sánchez. Testamentos vitais e diretivas antecipadas. In: Ribeiro, Diaulas Costa (Org.). A relação médico-paciente: velhas barreiras, novas fronteiras, 2010, p.110. O autor pontua que as diretivas antecipadas tem um alcance maior do que o consentimento informado, atribuindo a esse último o caráter de autonomia individual, e chamando as diretivas antecipadas de portadoras de uma autonomia ampliada ou autonomia prospectiva, já que seus efeitos serão sentidos quando o paciente tiver perdido sua capacidade e, portanto, sua autonomia individual.

142. PESSINI, Leo; BARCHIFONTAINE, Christian de Paul, op. cit., p. 289. No tocante à pesquisa em seres humanos, os autores inserem o respeito à autonomia como componente do próprio "respeito pelas pessoas", no sentido de respaldar a capacidade de autodeterminação das pessoas capazes. Daí também deriva o respeito pelas pessoas com autonomia diminuída, protegendo-as de abusos. Ainda que o fulcro dessa dissertação não seja a pessoa como objeto de pesquisa, perceba-se o quanto o princípio da autonomia importa em qualquer ato médico.

143. BOBBIO, Norberto. Teoria generale del diritto, 1993, p. 64.

144. "La distinzione tra imperativi autonomi ed eteronomi ha importanza per lo studio del diritto, perché ha constituto uno dei tanti criteri con cui si è voluto distinguere la morale dal diritto. Segundo Kant, si è detto che la morale si risolve sempre in imperativi autonomi e il diritto in imperativi eteronomi, dal momento che il legislatore morale è interno e il legislatore giuridico è esterno. In altre parole, questa distinzione vorrebbe suggerire che quandoci comportiamo moralmente, non ubbidiamo ad altri che a noi stessi, quando invece agiamo giuridicamente ubbidiamo a leggi che ci sono imposte da altri." BOBBIO, Norberto, op. cit., p. 64. 
o mestre italiano, ainda tendo como embasamento a teoria kantiana, que as normas morais, em tese internas, também podem seguir algum tipo de mando ou raiz externa, exemplificando aqui com a dogmática religiosa ${ }^{145}$, em que um ente externo, seja um líder religioso, seja o suposto mando de um ser supremo, dita as regras de conduta a seu rebanho. Ou seja, apesar de as diretrizes de conduta estarem eventualmente introjetadas no âmago da pessoa, suas prerrogativas tem uma gênese externa a ela. Por certo as normas morais heterônomas podem se chocar com as normas jurídicas, também heterônomas $^{146}$.

Para Kant, em A metafísica dos costumes, esse potencial imbricamento entre normas morais e normas legais pode ser deslindado pelo fato de que as normas legais são passíveis de sanção, o que não acontece em relação às normas morais ${ }^{147}$. Essas, mais afeitas à vontade, são, destarte, mais próximas ao conceito de autonomia.

Nesse diapasão, Gerald Dworkin comenta que a ideia de autonomia, ainda que ocupe uma posição sine qua non quando se pensa em diretrizes filosóficas, ainda não foi suficientemente dissecada pelos próprios filósofos ${ }^{148}$. Talvez por isso a definição de autonomia se confunda e ao mesmo tempo se relacione com os conceitos de liberdade, integridade, independência e outros ${ }^{149}$. O autor ressalta que autonomia é um termo nuclear, o que explica suas variadas aplicações. Além disso, coloca o conceito sob os prismas político, moral e social. Aplicado à política, pode carrear valores e atitudes sobre cidadãos de uma dada sociedade, tratando-os de forma justa e igualitária. No quesito social, pode canalizar a percepção da legitimidade social. E em sua faceta moral, talvez a que mais nos interesse para os fins desse estudo, pode nortear a aceitabilidade de normas postas, acolhendo-as ou não ${ }^{150}$.

145. BOBBIO, Norberto, op. cit., p. 65.

146. “(...) se consideriamo un sistema morale oposto a quello fondato sulla volontà divina, per exemplo un sistema morale inspirato ad una filosofia positivistica, per cui la morale è il complesso delle norme sociali che sono scaturite dai rapporti di convivenza tra gli uomini nel corso della loro storia, e formano quel che si disse l'ethos di un popolo, anche in questo caso ci troviamo di fronte ad una morale eteronoma, che non per questo si risolve imediatamente in un sistema giuridico." BOBBIO, Norberto, op. cit., p. 65. Nessa linha, também Tércio Sampaio Ferraz Jr., que demonstra a similaridade que existe entre as normas morais e as normas legais, eis que ambas tem um caráter prescritivo e vinculante. FERRAZ JR, Tércio Sampaio. Introdução ao estudo do direito - técnica, decisão, dominação, 1994, p. 355.

147. MASCARO, Alysson Leandro. Filosofia do direito, 2010, p. 222.

148. DWORKIN, Gerald. The theory and practice of autonomy, 2001, p. 4.

149. "(...) although not used just as a synonym for qualities that are usually approved of, "autonomy" is used in an exceedingly broad fashion. It is used sometimes as an equivalent of liberty (positive or negative in Berlin's terminology), sometimes as an equivalent to self-rule or sovereignty, sometimes as identical of freedom of the will. It is equated with dignity, integrity, individuality, independence, responsibility, and self-knowledge.It is identified with qualities of self-assertion, with critical reflection, with freedom from obligation, with absence of external causation, with knowledge of one's own interests.". DWORKIN, Gerald, op. cit., p. 6.

150. Idem, pp. 10-11. 
Ainda dentro de uma abordagem geral, a autonomia também pode ser estudada sob o viés das relações interpessoais: na medida em que a autonomia carrega em seu bojo o valor da autodeterminação, a percepção pelo seu titular reforça a autoestima e a autoconfiança, principalmente em seu aspecto inter-relacional. E, de maneira interessante, também fortalece a capacidade de respeitar a autonomia do outro ${ }^{151}$. Porém o sentimento de autonomia pode ser abalado por crises da vida, como doenças, acidentes ou perdas. A propósito, Maartje Schermer comenta que a autonomia pode ser vista como uma dicotomia entre um ideal de autenticidade e o direito de autodeterminação, e que uma atitude autônoma não pode ser cobrada de ninguém ${ }^{152}$.

Perceba-se que existem diversas maneiras de abordar o conceito de autonomia, o que denota a flagrante fluidez e complexidade do tema. Uma tentativa de classificar os conceitos do termo é lembrada por Lauren Davidson, reportando-se à formulação de N. Arpaly $^{153}$. Este autor delineia cinco significados para o vocábulo autonomia, e é sobre eles que discorreremos a seguir.

O primeiro significado, para Arpaly, relaciona-se com a "capacidade de se autorregular" ${ }^{154}$, que vem da origem etimológica grega cunhada no termo autonomia.

Nesse sentido, há um encadeamento forte entre o indivíduo e as suas motivações, em que a pessoa detém o poder de pautar seus próprios estados motivacionais, e de fazer uma hierarquização em face de seus "desejos, vontades ou crenças". Assim, essa capacidade é interna ao próprio agente, aproximando-se da definição de autonomia para Dworkin $^{155}$.

O segundo significado de autonomia é a autenticidade, o que significa que o indivíduo autônomo age de acordo com sua personalidade e seus valores entranhados. Entretanto, pode haver autenticidade nas ações direcionadas por valores absorvidos de aprendizagem externa, como uma religião, por exemplo. Arpaly comenta que momentos pessoais delicados, como enfermidades, por exemplo, podem não só fragilizar a

151. SCHERMER, Maartje. The different faces of autonomy - patient autonomy in ethical theory and hospital practice, 2002, p. 154.

152. SCHERMER, Maartje, op. cit., p. 155.

153. DAVIDSON, Lauren. The art of autonomy: on the use and usefulness of the term in clinical bioethics. In: Medicine and law, volume 32, number 2, June 2013, pp. 155-159.

154. Tradução livre do autor dessa dissertação para o que N. Arpaly denomina "capacity for self-rule". DAVIDSON, Lauren, op. cit., p. 155.

155. "The notion of autonomy as self-rule is evident in the work of Dworkin, who defines autonomy in this way:"...a second-order capacity of persons to reflect critically upon their first-order preferences, desires, wishes, and so forth and the capacity to accept to change these in light of higher-order preferences and values." "Idem, p. 155. 
autenticidade, mas que, em sentido inverso, podem reforça-la ${ }^{156}$.

O terceiro significado, para o mesmo autor, é a racionalidade, seguindo a concepção kantiana que assemelha autonomia da vontade e razão. Nessa linha, a conduta autônoma racional é passível de aferição por outras pessoas, justamente por conta de sua racionalidade. Assim, a capacidade de autorregulação da pessoa assume aqui uma diretriz racional ${ }^{157}$.

A independência da mente representa o quarto significado da autonomia, caracterizando atitudes ativas de decisão de seus titulares, em contraposição à passividade dos desprovidos de autonomia. Pode-se apreender facilmente esse conceito ao pensarmos em pessoas que não tem as rédeas sobre suas próprias decisões, das quais são cabais exemplos os que erigem suas opções com fulcro em dogmas religiosos ou aqueles que tomam decisões pessoais a mando de outrem ${ }^{158}$.

Por fim, a quinta e última concepção sobre autonomia segundo Arpaly, e certamente a que é mais usada no âmbito da bioética, é a permissão para lançar mão de preceitos morais em face de decisões que envolvem a vida ou a saúde. A fim de assegurar decisões isentas, há que seguir certos parâmetros para privilegiar a "independência e autenticidade" das opções. Por ser mais afeita à bioética em particular, esse quesito será retomado mais tarde neste estudo ${ }^{159}$.

\subsection{Psicologia da autonomia}

Grosso modo, a abordagem psicológica da autonomia a insere na teoria do desenvolvimento do $e u$. Segundo Dobert, Habermas e Nunner-Winkler ${ }^{160}$, a identidade se desenvolve em um plano subjetivo (teoria freudiana), intersubjetivo (teoria

156. DAVIDSON, Lauren, op. cit., p. 156.

157. Idem, p. 156.

158. Idem, p. 157. Nessa linha, em sede de direito penal, muito bem explana Hassemer em relação ao argumento de autoridade, antítese da autonomia: "A imagem de um Direito Penal curativo pode provocar fatos negativos. Ela pode apaziguar, onde a crítica seria necessária, ela pode harmonizar, onde seria necessária a discussão. O Direito penal real é, primeiramente, e, acima de tudo, imagens - uma instituição que se realiza sobre a força e não sobre o convencimento ou mediante a ajuda curativa (para esta última existem outras instituições sociais). $\mathrm{O}$ estabelecimento do consenso não pode depender do processo penal, mas do emprego do dissenso acompanhado da técnica adequada e digna do ser humano. Intermediar ao acusado que no processo penal se trata do estabelecimento de um acordo, significa manipulá-lo e aconselhá-lo de forma ruim.” HASSEMER, Winfried. Direito penal libertário, 2007, p. 76.

159. Idem, p 157.

160. cf. WILBER, Ken. Psicologia integral-consciência, espírito, psicologia, terapia, 2007, p. 308. 
interacionista simbólica) e cognitivo (teoria de Piaget). Esses três planos representariam os três ambientes em que se desenvolve crescentemente a autonomia, formatando a autonomia do indivíduo em relação a suas escolhas ${ }^{161}$.

De fato, é simples entender a autonomia como um processo de desenvolvimento, bastando olhar as crises e tropeços do desenvolvimento infantil, especialmente entre dois e seis anos de idade, em que ocorre "um esforço saudável por independência"162.

É certo que o estudo psicológico da autonomia, por sua complexidade, não será aprofundado nesse breve estudo, eis que não é seu escopo. Importa perceber, para esta abordagem, que as crises, percebidas como o conflito entre os desejos e as normas internas ou externas, e sentidas desde tenra idade, acompanharão o indivíduo ao longo de sua trajetória, e serão cruciais na tomada de decisões relativas ao fim da vida.

\subsection{Autonomia e valores constitucionais}

Dentro dos aspectos constitucionais atinentes à autonomia, esta pesquisa se limitará aos aspectos individuais. Isso porque, em várias passagens da Constituição Federal, a autonomia se refere a aspectos estatais, funcionais e de soberania que, por óbvio, passam muito longe do objeto de uma pesquisa que quer esmiuçar o viés pessoal na análise da autonomia.

A Carta Magna indiretamente consagra a autonomia logo em seu Preâmbulo, ao garantir ao povo brasileiro o exercício dos direitos individuais e da liberdade. Como bem ensina José Afonso da Silva, o Preâmbulo "é a expressão solene de propósitos"163, que vai definir o próprio caráter do texto constitucional que o segue. Na medida em que os direitos individuais e a liberdade integram expressamente os valores supremos da Constituição Federal, é certo que irão permear a essência e a interpretação da Constituição Federal e também das normas constitucionais, sempre que surja alguma dúvida hermenêutica. Silva traça um paralelo entre os "valores supremos" da Carta

161. "A autonomia crescente é um dos vinte princípios exibidos por todos os sistemas evolutivos, inclusive o eu - e a Autonomia final é simplesmente o puro Eu, fora do qual nada existe, e que é, portanto, um estado de plena autonomia (...) A razão pela qual o desenvolvimento mostra autonomia crescente é que o desenvolvimento está dirigido para a autonomia suprema do Eu puro e não-dual." WILBER, Ken, op. cit., 2007, p. 309.

162. DE MARCO, Mario Alfredo et al. Psicologia médica - abordagem integral do processo saúdedoença, 2012, p. 194.

163. SILVA, José Afonso da. Comentário contextual à Constituição, 2010, p. 23. 
pátria e os "valores superiores" da Constituição espanhola, destacando a força normativa e vinculante que deságua desses valores na direção das normas jurídicas em geral $^{164}$.

Nesse diapasão, a Carta atual, diferentemente dos textos constitucionais que a antecederam, consagra não os valores direcionados para um bem comum, mais compatíveis com as Constituições republicanas, mas sim, por conta de sua ideologia liberal, dá azo ao atingimento da felicidade individual ${ }^{165}$. Ao elencar, no artigo $3^{\circ}$, inciso I, a construção de uma sociedade livre como objetivo fundamental, reforça os valores que foram explicitados no Preâmbulo. Isso quer dizer que o fulcro da Carta é a construção de uma "ordem de homens livres"166.

O extenso artigo $5^{\circ}$ da Lei Maior brasileira é um verdadeiro apanhado de direitos fundamentais, e nesse sentido vários de seus incisos se relacionam com o que se apreende como autonomia. Começando pelo caput, que novamente consagra a liberdade como direito fundamental, aqui entendida, segundo José Afonso da Silva, sob algumas facetas: a "liberdade do querer" compreende a capacidade da pessoa em fazer suas próprias escolhas; a "liberdade objetiva" significa a ausência de coações, ou seja, a liberdade aqui é definida como uma característica externa, que permite o agir independente ${ }^{167}$. Perceba-se, nesse ponto, a evidente identidade entre o enfoque da liberdade pelo autor constitucionalista e as definições de autonomia que foram citadas linhas acima, quando se colocou sua conceituação em sede geral.

Nessa seara, uma das características de nossa atual Constituição, ao estar imbuída de valores liberais, é a preservação da autonomia individual em face ao poder do Estado, garantindo-a e preservando-a ${ }^{168}$. Um dos grandes teoristas da concepção liberal, Habermas, ao contrapor autonomia privada a autonomia pública, destaca que a autonomia privada se confunde com a tutela dos direitos subjetivos, dentro do chamado

164. SILVA, José Afonso da, op. cit., p. 25. Vale lembrar, porém, o contraponto a essa questão, expresso por Uadi Bulos, que considera o preâmbulo da Constituição da República como sendo desprovido de força cogente. Por conta disso, diz o autor que melhor seria o constituinte ter atribuído a qualidade de "superioridade", e não de "supremacia", aos valores da liberdade, segurança, bem-estar, desenvolvimento, igualdade e justiça, pois para ele chamar esses valores de supremos seria indicar que eles se sobrepõem às normas constitucionais. BULOS, Uadi Lammêgo. Curso de direito constitucional, 2011, p. 493.

165. SAMPAIO, José Adércio Leite. Constituição e crise política, 2006, p. 185-186.

166. SILVA, José Afonso da, op. cit., p. 48.

167. Idem, p. 70.

168. OLIVEIRA, Flávio Luís de. Princípio do acesso à justiça. In: Lopes, Maria Elizabeth de Castro; Oliveira Neto, Olavo de (orgs.). Princípios processuais civis na Constituição, 2008, p. 84. 
estado democrático de direito ${ }^{169}$. Entretanto, pontua o doutrinador germânico que os limites entre autonomia pública e privada nem sempre são claros, vez que possuem uma mesma origem. Além disso, "os limites entre a autonomia pública e privada estão em processo" 170 .

Cambiando para o ordenamento constitucional lusitano, historicamente muito próximo do brasileiro, é necessário lembrar José Joaquim Gomes Canotilho, que aponta o Estado de Direito como o reconhecimento, por este Estado, da dignidade humana (à qual nos reportamos anteriormente neste estudo) e da autonomia individual; nesse sentido, o Estado deve ser o garante dessas duas qualidades ${ }^{171}$.

\subsection{Autonomia e negócio jurídico}

É interessante analisar as diretivas antecipadas de vontade para o fim da vida, passando pela autonomia que lhe é subjacente, sob o viés de negócio jurídico. Afinal, a vontade, componente do próprio nomen juris das diretivas, é parte fundamental e fundamentadora do negócio jurídico. Como tal, as diretrizes relacionadas à autonomia em sede civilista serão aqui sucintamente abordadas.

$\mathrm{Na}$ teoria dos contratos, um dos quatro princípios basilares, junto com o do consensualismo, o da força obrigatória e da boa-fé, é o da autonomia da vontade ${ }^{172}$.

Orlando Gomes ensina que a autonomia da vontade cristaliza-se na liberdade de contratar, e que essa passa pelos poderes "de auto-regência de interesses, de livre discussão das condições contratuais e, por fim, da escolha do tipo de contrato conveniente à atuação da vontade" ${ }^{173}$.

169. "Os liberais acentuaram as "liberdades dos modernos", em primeira linha a liberdade da crença e consciência, bem como a defesa da vida, da liberdade e propriedade pessoal, ou seja, o cerne dos direitos civis subjetivos; em face disso, o republicanismo defendeu as "liberdades dos antigos", quais sejam os direitos políticos de participação e comunicação que possibilitam a práxis autodeterminante dos cidadãos. Rousseau e Kant tinham a ambição de derivar os dois elementos de uma mesma raiz, ambos como primordiais: nem se podem simplesmente abafar os direitos básicos liberais da práxis autodeterminadora como sendo restrições externas, nem se pode instrumentalizá-los em prol dessas mesmas restrições." HABERMAS, Jürgen. A inclusão do outro, 2007, p. 87.

170. HABERMAS, Jürgen, op. cit., p. 89.

171. CANOTILHO, José Joaquim Gomes; MOREIRA, Vital. Fundamentos da Constituição, 1991, p. 74.

172. GOMES, Orlando. Contratos, 2009, p. 25.

173. GOMES, Orlando, op. cit., p. 26. Nessa linha, também Sílvio Venosa, que ressalta que há discussões acerca do teor da vontade, delimitando-se duas correntes: uma delas, chamada teoria da vontade, foca na necessidade de conhecer a vontade interna do agente; a ela se contrapõe a teoria da declaração, para qual pouco importa a vontade íntima do agente, desde que esse declare de forma adequada. VENOSA, Sílvio de Salvo. Direito civil - parte geral, 2008, p. 354-355. A segunda teoria é acolhida por Antônio Azevedo. AZEVEDO, Antônio Junqueira de. Negócio jurídico - existência, validade e eficácia, 2010, p. 85. 
Nesse sentido, representam os elementos essenciais ao negócio jurídico: capacidade do agente, objeto lícito e possível, consentimento, e formas e solenidades previstas em lei ${ }^{174 .}$ Interessa, nesse ponto, frisar que a capacidade do agente relaciona-se de perto com sua declaração de vontade, entendendo-se essa declaração como pressuposto do negócio jurídico. Portanto, "o ato praticado pelo absolutamente incapaz é nulo (Código Civil, artigo 166, inciso I), e o realizado pelo relativamente incapaz sem assistência é anulável (Código Civil, artigo 171, inciso I)"175.

Com relação a essa capacidade, que corre pari passu com a autonomia, Marcos de Mello destaca sua essência de pessoalidade. Relata o autor que as pessoas em geral possuem a capacidade, porém nem todos os seres humanos são titulares dela. Ou seja, são incapazes aqueles que, por um motivo ou outro, são abrangidos por uma norma que excepciona a situação de capacidade das pessoas em geral ${ }^{176}$. Dentre esses motivos, Mello elenca a idade, a sanidade física e mental, a condição cultural, e as causas de interdição legal ${ }^{177}$.

Há que se atentar, nesse ponto da dissertação, à questão do poder de disposição que o titular da capacidade possui, entendendo-se que "dispor de um bem ou de um direito significa poder transmiti-lo a outrem, a ele renunciar ou abandoná-lo" ${ }^{\text {178 }}$. Para os fins desse texto, interessa-nos particularmente a questão da transmissibilidade a uma terceira pessoa, aspecto que será crucial quando analisarmos a questão do representante de cuidados para saúde no fim da vida, que é quase ínsito às diretivas antecipadas de vontade para o fim da vida. Nesse aspecto, a norma é excepcionada no sentido de legitimar um terceiro que não é o titular do atributo de capacidade, podendo essa eventualidade acontecer, e.g., no caso de uma pessoa ser considerada judicialmente incapaz $^{179 .}$ A disposição pode ter origem legal (como no exemplo acima) ou negocial,

174. DINIZ, Maria Helena. Curso de direito civil brasileiro - teoria geral do direito civil, 2008, p. 439. 175. DINIZ, Maria Helena, op. cit., p. 440.

176. MELLO, Marcos Bernardes de. Teoria do fato jurídico - plano da validade, 2008, p. 25.

177. A saber: a) idade: a capacidade plena é alcançada aos 18 anos no ordenamento jurídico nacional; entre os dezesseis e os dezoito anos há incapacidade relativa para os atos da vida civil; o menor de dezesseis é absolutamente incapaz; b) sanidade mental e física: prejuízo das faculdades mentais pode levar a capacidade relativa ou absoluta, dependendo de sua gradação, assim como a deficiência mental e a "privação do pleno domínio dos sentidos"; aqui também se inclui a prodigalidade; c) condição cultural: aqui se fala especificamente da situação do silvícola; d) interdição legal: válida, segundo alguns autores, entre os quais Orlando Gomes, para pessoas condenadas a penas privativas de liberdade; essa causa não é consensual na doutrina, e Mello não a esposa. MELLO, Marcos Bernardes de, op. cit., pp. 27 e ss.

178. Idem, p. 34.

179. Idem, ibidem. 
sendo que nesse caso a transmissibilidade ocorre no seio de um contrato.

Entretanto, o poder de alienação sofre restrições derivadas da própria natureza do direito em tela, sendo certos direitos, como os de personalidade, considerados indisponíveis. Por sua vez, os direitos de personalidade são elencados, numerus clausus, como o direito à vida, à própria imagem, ao nome e à privacidade ${ }^{180}$. Limongi França especifica os direitos da personalidade como o direito à integridade física, o direito à integridade intelectual, e o direito à integridade moral (Código Civil, artigos 16, 17, 18, $19,20$ e 21$)^{181}$.

Parte da doutrina admite, porém, que os direitos de personalidade ainda carecem de melhor definição quanto a questões erigidas de situações fáticas contemporâneas, como, por exemplo, os transplantes de órgãos ${ }^{182}$. Em tese, aqui haveria vedação ao ato, vez que seria atentatório à integridade física. Porém, ao dar respaldo à autonomia do doador, a própria doutrina admite flexibilizar a vedação da disponibilidade dos direitos de personalidade, por conta das novas problemáticas nascidas do campo do Biodireito e da Bioética, assunto do próximo tópico.

\subsection{Autonomia e bioética}

As opções do paciente-cliente em face de sua própria saúde se revestem de peculiaridades especiais. Por vezes, não são possíveis decisões racionais por conta do seu próprio estado físico-psíquico, e pertencem a este grupo os doentes mentais e os pacientes passíveis de tratamento emergencial; em outras situações, em regra a própria patologia implica em um estado emocional de dependência em relação às equipes de saúde, estado esse que de certa forma alija ou mitiga a autonomia da pessoa, afetando sua capacidade de escolha ${ }^{183}$.

180. Sílvio Venosa comenta que “(...) os direitos da personalidade possuem as seguintes características: (a) são inatos ou originários porque se adquirem ao nascer, independendo de qualquer vontade; (b) são vitalícios, perenes ou perpétuos, porque perduram por toda a vida. Alguns se refletem até mesmo após a morte da pessoa. Pela mesma razão são imprescritíveis porque perduram enquanto perdurar a personalidade, isto é, a vida humana. $\mathrm{Na}$ verdade, transcendem a própria vida, pois são protegidos também após o falecimento; são também imprescritíveis; (c) são inalienáveis, ou, mais propriamente, relativamente indisponíveis, porque, em princípio, estão fora do comércio e não possuem valor econômico imediato; (d) são absolutos, no sentido de que podem ser opostos erga omnes. Os direitos da personalidade são, portanto, direitos subjetivos de natureza privada. VENOSA, Sílvio de Salvo, op. cit., p. 169.

181. $c f$. DINIZ, Maria Helena, op. cit., p. 122.

182. Idem, p. 123.

183. FREIRE, Paula Vaz. A regulação da saúde: uma perspectiva comportamental. In: ALONSO, RP; KAZMERCZAK, LF. Estudos contemporâneos de bioética e biodireito, p. 76. 
Feita, porém, essa ressalva inicial, importa frisar que a autonomia representa, dentro da ciência da Bioética, um dos quatro pés que fundamenta esse importante ramo doutrinário. Compõe, junto com a beneficência, não-maleficência e justiça, aquilo que dá o norte em todas as decisões, cada vez mais delicadas, que envolvem o trato com os parâmetros éticos relacionados à saúde.

Para que tenha capacidade de decidir seu próprio destino, há algumas condições a serem satisfeitas: a pessoa deve agir de forma intencional, querendo obter um determinado fim; deve conhecer o que faz e as consequências de seus atos; e deve estar isento de influências externas, agindo de forma livre ${ }^{184}$. Nesse diapasão, a liberdade de escolha, paradigma da autonomia, pressupõe, de forma crucial, os moldes do que hoje se entende devam ser os liames da relação médico-paciente ${ }^{185}$. Ao mitigar a antiga postura paternalista do médico, em prol de uma atitude com essência contratual, mais arejada e derivada da informação, a novel atividade médica abriu caminho para a autonomia do paciente ${ }^{186}$. Ao premiar essa nova forma de relacionamento entre profissional da saúde e paciente, consagrada no Código de Ética Médica atual (artigos 24 e 31, já citados anteriormente neste trabalho), surge o desafio de, mesmo com uma restrita delimitação ético-profissional, deixar de lado o que James Childress e Mark Ziegler chamam de "medicina entre estranhos", aquela que segue meramente normas, e abrir caminho para a "medicina entre próximos", focada na mútua confiança ${ }^{187}$. Em outros termos, remeter, no pensar de Maria Rita Kehl, a uma perdida, porém preciosa, subjetividade ${ }^{188}$.

184. DALL'AGNOL, Darlei. Bioética, 2005, pp. 15-16.

185. “(...) na relação médico-paciente, a partilha de poder permite que os pacientes cuidem de si mesmos em vez de criar com ele uma relação de dependência. Essa alteração no tocante ao cuidado de pacientes com doenças crônicas como asma e diabetes tem tido um forte impacto tanto no bem-estar individual como na satisfação do médico.” GARRAFA, Volnei; PESSINI, Leo. Bioética: poder e injustiça, 2004, p. 32.

186. Comenta a esse respeito Fernando Scaff: "Tal realidade impede que se pense, atualmente, na figura do paciente como um destinatário meramente passivo e subordinado aos atendimentos médicos, ou que tenha a sua opinião e desejos olimpicamente desconsiderados durante o curso do tratamento, ou ainda que deva se submeter, de maneira absoluta e obediente, às orientações e procedimentos escolhidos unilateralmente pelo profissional de Medicina". SCAFF, Fernando Campos. Direito à saúde no âmbito privado - contratos de adesão, planos de saúde e seguro-saúde, 2010, p. 24. No mesmo sentido, José Barbieri: “(...) o paciente se encontrará numa posição um pouco mais equânime em relação ao médico, detentor deste conhecimento. A partir daí, respeitada a dignidade do paciente, este poderá decidir seu tratamento, e assim decidindo, como se dará. Esta decisão, este consentimento, advém do princípio da autonomia." BARBIERI, José Eduardo. Defesa do médico - responsabilidade civil e a inversão do ônus da prova sob a ótica da Bioética, 2008, p. 50.

187. $c f$. PESSINI, Leo; BARCHIFONTAINE, Christian de Paul. Problemas atuais de bioética, 2008, p. 548.

188. "Mas a subjetividade é mais difícil de controlar do que parece. A única forma de relacionamento humano que vale a pena cultivar, a única capaz de nos ajudar a sobreviver ao tédio e à solidão é aquela onde existe espaço para sermos subjetivos. Nada a ver com a atitude "salve-se quem puder" que predomina nas formas de relacionamento modernosas, nada a ver com a atitude do "defender o meu, que 
Nesse sentido, denota-se que o paciente, detentor de sua autonomia, e derivado dela, assume perante as equipes de saúde sua parte em relação a seus próprios cuidados com a saúde. Ou seja, ao deixar de ser objeto da tutela paternalista de outrora, o paciente carrega o quinhão de responsabilidade de resguardar por sua sanidade, fazendo uso eficaz daquilo que as equipes médicas o orientam. O contrário pode se reverter até em problema de saúde pública, na visão de algumas escolas europeias ${ }^{189}$.

A cristalização do conceito bioético de autonomia é o consentimento informado, sobre o qual nos referimos anteriormente nesse estudo, e que segundo Beauchamp e Childress pode ser decomposto em um total de sete elementos ${ }^{190}$. Fazem parte desse rol duas precondições, que são a competência para entender as informações que são fornecidas, e a voluntariedade para poder decidir livremente, sem que haja focos de coerção. Há também três elementos de informação, quais sejam: a oferta da informação, que deve ser clara e realizada com isenção; a recomendação de um plano terapêutico, devidamente explanado e justificado; e o entendimento por parte do paciente, que deve ser checado por parte do profissional de saúde. Por fim, há dois elementos de autorização: a decisão do paciente na direção de uma proposta terapêutica previamente informada e entendida, de forma ideal obtida sem que o detentor da autonomia não seja pressionado; e a autorização do que foi decidido, que conclui o processo.

Os referidos autores, entretanto, fazem a ressalva de que o conceito de autonomia carrega uma grande carga de subjetividade, o que o torna especialmente complexo e faz com que esse importante paradigma bioético esteja em constante construção ${ }^{191}$. Nessa linha, suas diretrizes devem ser sopesadas, em cada caso clínico, com os outros fundamentos da ética biomédica: a beneficência, a não-maleficência e a justiça.

se dane o outro" (...) minha subjetividade, minha possibilidade de ser sujeito de mim, requer a morte do outro?" KEHL, Maria Rita. Viver é conviver. In: PESSINI, Leo; BARCHIFONTAINE, Christian de Paul, op. cit., p. 253.

189. GIGNON, Maxime et al. Finding a balance between patients' rights, responsibilities and obligations. In: Medicine and law, volume 32, number 3, September 2013, p. 321.

190. BEAUCHAMP, Tom L.; CHILDRESS, James F. Principles of biomedical ethics, 2013, pp. 124 e ss. 191. Idem, pp. 140-141. “(...) Although we have justified the obligation to solicit decisions from patients and potential research subjects by the principle of respect for autonomy, we have also acknowledged that the principle's precise demands remain unsettled and open to legitimate interpretation and specification. We have criticized various approaches that have been taken to obtaining consents, but we should be mindful that the history of informed consent and the place of autonomy in biomedical ethics are still under development." 


\section{Definições terminológicas das diretivas antecipadas de vontade}

A construção da linguagem no direito, de resto como em qualquer ramo do conhecimento, tem como escopo evitar deturpações que eventualmente levem a desvios de raciocínio ao se pensar sobre determinado instituto. O direito, visto como ciência, utiliza a terminologia jurídica como ferramental da aplicabilidade das normas ${ }^{192}$. Em que pese o conceito kelseniano de norma ${ }^{193}$ na atualidade parecer demasiado estanque e demodé, eis que o direito hoje, felizmente, é imbuído de maior fluidez e essência jusnaturalística, não há dúvida de que a norma ainda é cara ao direito, e disso decorre a importância da precisão de seus enunciados.

No caso do tema em tela, existe certa polêmica terminológica, talvez fruto da novidade do instituto em território nacional. Parte dos poucos estudiosos brasileiros que se debruçam academicamente sobre o assunto ${ }^{194}$ chamam as diretivas antecipadas de vontade para o fim da vida de "testamento vital", certamente sob a influência da doutrina norte-americana, a primeira que aplicou na prática o instituto, e que o denomina de "living will". Esta expressão, vertida para o português, foi enunciada como sendo "testamento vital".

Entretanto, a nomenclatura mais adequada parece ser "diretivas antecipadas de vontade para o fim da vida", e que será esposada pelo autor desse estudo, com um fundamento dúplice. Primeiro, porque testamento se relaciona a um instituto que só possui eficácia após a morte ${ }^{195}$. Segundo, porque a ponta de lança do acolhimento do instituto em nosso país, na forma de normatização de cunho ético-disciplinar, foi a Resolução 1995, de 31 de agosto de 2012, do Conselho Federal de Medicina; como esta resolução utiliza o termo "diretivas antecipadas de vontade", esse é o termo a ser adotado. Parece inconveniente obnubilar com uma imprecisão terminológica um

192. “(...) não resta dúvida que a Ciência do Direito não só descreve objetos, como prescreve condutas ao influir no meio social, e sendo uma ciência humana e social engajada com a problemática do ser humano em seu meio, daí recebe influências e aí exerce seu poder de informação e educação." NUNES, Luiz Antônio Rizzatto. A intuição e o direito - um novo caminho, 1997, p. 206. Na mesma linha, Tércio Ferraz Jr. comenta: "A língua é vista como um sistema de signos, cuja relação com a realidade é estabelecida arbitrariamente pelos homens. Dado este arbítrio, o que deve ser levado em conta é o uso (social ou técnico) dos conceitos, que podem variar de comunidade para comunidade." FERRAZ JR. Tércio Sampaio, Introdução ao estudo do direito - técnica, decisão, dominação, 1994, p. 35.

193. KELSEN, Hans. Teoria pura do direito, 2006, pp. 4 e ss.

194. Dentre outros: BORGES, Roxana Cardoso Brasileiro. Direito de morrer dignamente: eutanásia, ortotanásia, consentimento informado, testamento vital, análise constitucional e penal e direito comparado. In: SANTOS, Maria Celeste Cordeiro Leite (org.). Biodireito - ciência da vida, os novos desafios, 2001, p. 295. Também: GUIMARÃES, Marcello Ovídio Lopes. Eutanásia - novas considerações penais, 2011, pp. 163 e ss.

195. Nesse sentido, DADALTO, Luciana. Testamento vital, 2013, p. 16. 
instituto que per se já carrega, como veremos, uma grande dose de inquietação doutrinária.

\section{Origem e conceituação}

\subsection{Histórico}

A origem das diretivas antecipadas se deu nos Estados Unidos. De maneira interessante, por sua similaridade com o atual e tardiamente nascente estágio desse instituto no Brasil, sua normatização foi antecedida por um período pré-legislativo ${ }^{196}$ Nessa época, a função do documento era variada: a) permitir uma menor penalização do profissional de saúde que assistisse um doente em que fossem tomadas medidas para apressar o processo de morte; b) alicerçar o doente em sua decisão de morrer; c) ser um instrumento para a expressão da vontade do paciente. Segundo González, é notório que a discussão sobre as diretivas nessa fase giravam em torno da possibilidade da própria eutanásia $^{197}$.

Após algumas tentativas frustradas de legalização, surgiu em 1991 uma lei federal que deu azo à autodeterminação do paciente, denominada Patient Self Determination Act. Impulsionada por alguns casos emblemáticos, como o de Karen Ann Quinlan, que ficou muito tempo em coma, a normativa aproximava-se mais do que hoje se entende por diretiva antecipada de vontade, no sentido de prover as pessoas de uma autorização para retirada de tratamento médico ${ }^{198}$.

Ainda nessa época, a partir do início da década de 1990, o foco foi a difusão de conceitos sobre as diretivas antecipadas de vontade, após a aprovação de legislação pertinente em vários estados norte-americanos ${ }^{199}$.

196. GONZÁLEZ, Miguel Ángel Sánchez. Testamentos vitais e diretivas antecipadas. In: RIBEIRO, Diaulas. A relação médico-paciente: velhas barreiras, novas fronteiras, 2010, p. 112 . O autor comenta que nesse período, anterior a 1976, o living will consistia em um "documento de cuidados antecipados, no qual os indivíduos poderiam especificar sua vontade de suspender intervenções médicas de manutenção da vida".

197. Idem, ibidem.

198. GONZÁLEZ, Miguel Ángel Sánchez, op. cit., p. 113. A esse respeito, Nicole Saita e Samuel Hodge Jr. lembram que o caso Karen Ann Quinlan foi a ponta de lança para que a sociedade abrisse os olhos para o problema da manutenção artificial da vida em uma pessoa em estado vegetativo persistente e sem possibilidade de cura: "The New Jersey Supreme Court, reliant on the physician's statement that there was no reasonable possibility of Karen ever emerging from her comatose state, agreed that life-support systems could be withdrawn on the basis of her right to privacy without criminal or civil liability. In this case, the court began to address questions concerning "prolongation of life" and noted the paucity of legislation in this area, a recurrent theme cited by the courts in subsequent years." SAITTA, Nicole Marie; HODGE Jr., Samuel D. What are the consequences of disregarding a "do not resuscitate directive" in the United States? In: Medicine and Law, volume 32, number 4, 2013, p. 443.

199. Idem, ibidem. 
O primeiro estado dos Estados Unidos a regular a questão havia sido a Califórnia, em 1976. A partir daí, todos os estados americanos e também os territórios de Guam, Porto Rico e Ilhas Virgens legislaram sobre o tema ${ }^{200}$, cada um deles seguindo características próprias, já que a lei norte-americana tem âmbito estadual.

Em território europeu, as diretivas antecipadas surgiram mais tarde, na década de 1990. O impulso ético-legal para sua implantação em alguns países europeus foi a “Convenção para a proteção dos direitos do homem e da dignidade do ser humano face às aplicações da biologia e da medicina", ou simplesmente "Convenção Europeia de Bioética”. Essa convenção foi assinada na cidade espanhola de Oviedo, por conta do qual também é conhecida como "Convenção de Oviedo", em 4 de abril de 1997, entrando em vigor na ordem internacional da Europa em $1^{\circ}$ de dezembro de 1999. Fruto de seis anos de reuniões do Conselho da Europa, a Convenção foi aprovada pelos 40 Estados-membros do Conselho, e referendada por 21 países $^{201}$. Seu texto regula várias áreas da Bioética, sendo que para os fins desse estudo interessa particularmente o artigo $9^{\mathbf{o}^{202}}$. Ao respaldar a vontade do paciente em face de tratamentos médicos ulteriores, desde que previa e claramente expressada, este artigo abre um caminho normativo para a concretização das diretivas antecipadas de vontade para o fim da vida, o que efetivamente ocorreu em países como Portugal e Espanha ${ }^{203}$.

No Brasil, ainda não há como se falar em aspectos históricos, vez que as diretivas ainda são um instituto muito recente, estando representadas pela regulação de cunho ético, na forma da Resolução 1995/2012 do Conselho Federal de Medicina. Vale lembrar, nesse ponto da dissertação, que esta Resolução nasceu dos novos ventos da moderna Bioética, cujos efeitos se fazem sentir em solo pátrio, traduzidos no atual Código de Ética Médica, e que privilegiam a autonomia e o consentimento, já discutidos anteriormente neste estudo.

200. SAITTA, Nicole Marie; HODGE Jr., Samuel, op. cit, p. 444.

201. SERRÃO, Daniel. A Convenção Europeia de Bioética e a prática médica em Portugal, acesso virtual em www.danielserrao.com/gca/index.php?id=109 em 10/04/2014.

202. Artigo 9: "Vontade anteriormente manifestada - A vontade anteriormente manifestada no tocante a uma intervenção médica por um paciente que, no momento da intervenção, não se encontre em condições de expressar a sua vontade, será tomada em conta."

203. ARCOS, Maria Luisa. Notes on patients with disabilities autonomy in Spanish law. In: Medicine and law, volume 32, number 4, 2013, p. 609. Com relação à Espanha, a autora menciona: "Based on Art. 9 of the Convention on Human Rights and Biomedicine, the Law 41/2002, on Patient's Autonomy and on Rights and Obligations with regard to Clinical Information and Documentation, admitted the patient's right to the respect of his/her will in regard to healthcare preferences, even in case of current incompetence, provided this will had previously been expressed, in writing." 


\subsection{Abordagem conceitual}

A diretiva antecipada de vontade para o fim da vida é um documento pelo qual uma pessoa capaz expressa seus desejos sobre como quer ser tratado em uma situação futura de terminalidade da vida em que já não tenha mais capacidade de expressar sua vontade. É um documento, dotado de graus variáveis de formalidade e detalhamento, em que a pessoa define os parâmetros de tratamento que devem ser seguidos caso se encontre "irremediavelmente doente ou incapacitada" 204 . Nesse sentido, uma diretiva antecipada de vontade para o fim da vida pode conter instruções que orientem as equipes médicas a não utilizarem, por exemplo, medidas extremas ou "heroicas" para manter o sujeito vivo, em uma situação em que elas sejam passíveis de ser utilizadas ${ }^{205}$. Ou seja, a essência das diretivas antecipadas se contrapõe de maneira cabal à distanásia, e se identifica com a concepção da ortotanásia.

Indo mais além, entretanto, as diretivas antecipadas de vontade são plenamente aplicáveis às situações de eutanásia passiva, que, como frisamos anteriormente neste estudo, é entidade diferente da ortotanásia. Nesta, o processo de morte é conduzido pela equipe médica no intuito de dar conforto ao paciente, entendendo aqui conforto em sua mais ampla acepção; ou seja, pode incluir o respeito à vontade do paciente de morrer em seu domicílio, por exemplo, e não no asséptico e impessoal ambiente hospitalar. A ortotanásia, seja em que ambiente for, não prescinde do aparato técnico-procedimental de combate à dor, com o uso liberal de analgesia e sedação, conforme o caso particular. No caso da eutanásia passiva, a equipe de assistência à saúde se abstém de manter a vida do paciente, por meios omissivos, dos quais o exemplo mais emblemático é a cessação de nutrição enteral ou parenteral.

Ainda que as concepções de eutanásia passiva e ortotanásia sejam distintas, pode se configurar situação clínica em que a delimitação não seja tão clara. As cruciais ordens de não-reanimação cardio-pulmonar, por exemplo, podem ser percebidas como eutanásia passiva, vez que envolvem atitude omissiva, mas também podem constar do rol da ortotanásia, pois ao evitar o "encarniçamento terapêutico" que caracteriza a

204. COLLINS Jr., Evan R.; WEBER, Doron. The complete guide to living wills - how to safeguard your treatment choices, 1991, p. 7.

205. GODKIN, M. Dianne. Living will, living well - reflections on preparing an advance directive, 2008, p. 7. Nesse diapasão, também Nancy King: "An advance directive is a written statement that is intended to govern health care decision-making for its author, should he or she lose decisional capacity in the future. Though by this definition advance directives can apply to any health-care decision, they are almost always addressed to end-of-life issues, and it is in this context that they are best known." KING, Nancy M. P., Making sense of advance directives, 1996, p. 2. 
distanásia, favorecem a harmonia do processo da morte, típica da ortotanásia ${ }^{206}$.

Mesmo que em uma dada situação clínica os liames entre ortotanásia e eutanásia passiva sejam bem marcados, parece muito estreito o horizonte doutrinário que limita a aplicação das diretivas à ortotanásia, alijando a eutanásia passiva dessa possibilidade de autorização prévia. Essa temática será retomada ao longo da fundamentação dessa pesquisa.

Por ora, importa ressaltar que o leitmotiv das diretivas, e que solidifica progressivamente sua moldagem bioética, é a rejeição crescente em face do exagero no emprego das novas tecnologias avançadas para o suporte da vida. Os efeitos colaterais do aparato médico-tecnológico, utilizado principalmente em medicina intensiva, trouxeram à baila temores relativos à manutenção da vida protraída ao longo do tempo $^{207}$. Nesse diapasão, as diretivas se traduzem como um instrumento para o controle das decisões médicas a posteriori, consagrando a expressão das vontades pessoais dos pacientes-clientes no tocante às terapêuticas às quais podem ser $\operatorname{submetidos}^{208}$.

Isso ocorre muito por conta das condições que perpassam o processo da morte na

206. Livia Pithan, em obra dedicada especificamente ao tema desafiador das ordens de não-ressuscitação, polemiza o assunto nos seguintes termos: "Consiste em eutanásia a não-reanimação de paciente irreversível? Pode-se distinguir eticamente o ato de aplicar uma injeção letal em um paciente terminal para apressar sua morte de uma não-reanimação? O que os juristas dedicados nessa temática tem entendido sobre a diferença entre "matar" e "deixar morrer"? Pode-se afastar o rechaço à obstinação terapêutica do âmbito jurídico-penal?" PITHAN, Livia Haygert. A dignidade humana como fundamento jurídico das "ordens de não-ressuscitação hospitalares", 2004, p.44. Mais à frente, a mesma autora propõe: "O termo eutanásia passiva, que se refere à morte de paciente decorrente de uma omissão ou retirada de recurso terapêutico, muitas vezes é utilizado indiscriminadamente sem se avaliar a adequação do tratamento. Porém, há que se observar que em algumas situações os recursos terapêuticos são necessários, podendo trazer benefícios ao doente; já em outras situações, esses mesmos tratamentos não beneficiam o paciente, tornando-se desnecessários, desproporcionais ou fúteis." PITHAN, Livia Haygert, op. cit., p. 46. No mesmo sentido, na doutrina portuguesa: "Intimamente relacionado com a eutanásia homicida por omissão está o problema da ortotanásia que está ao rubro dos nossos dias: saber se se deve ou não permitir a sobrevivência puramente vegetativa de doentes que do ponto de vista clínico estão impossibilitados de recuperar - apenas vão vivendo enquanto estiverem ligados a máquinas que lhes prolongam a vida artificialmente - o que acontece, muitas vezes para além de limites razoáveis (...) BRITO, José dos Santos Lopes de; RIJO, José Manuel Subtil; Estudo jurídico da eutanásia em Portugal - direito sobre a vida ou dever de viver?, 2000, p. 113. Frente à situação médica emergencial, a questão pode colocar o profissional de saúde frente a um dilema: “(...) este entendimento está longe de ser pacificado. Embora se possa aduzir que a própria Constituição Federal garante o princípio da dignidade humana e que uma ordem de não-ressuscitação pode ser comparada a um ato de morte digna, é um pensamento que contraria, para alguns, a própria Constituição, quando resguarda a proteção da vida." CHAPLEAU, Will. Manual de emergências: um guia para primeiros socorros, 2008, p. 46.

207. "O mero prolongamento quantitativo da vida, pelo preço da dependência da medicina intensiva, é concebido frequentemente como em desacordo com a dignidade do falecimento. A ética e a ordem jurídica aproveitaram essa percepção e colocaram como norma central a noção da autodeterminação ou do respeito por concepções pessoais e manifestações de vontade de pacientes. Isso corresponde ao conhecimento moderno de que liberdade e autodeterminação são expressão da dignidade humana." KRESS, Hartmut. Ética médica, 2008, p. 305-306.

208. CANTOR, Norman L. Advance directives and the pursuit of death with dignity, 1993, p. 23. 
atualidade. O desenlace da morte no seio de sua própria família e em seus próprios aposentos, ou seja, na segurança da intimidade doméstica do moribundo, parecem cada vez mais distantes na atual sociedade medicalizada ${ }^{209}$. E além da medicalização, houve também um processo de privatização do falecimento, apartando o doente terminal de sua base social, uma vez que o aspecto "disfuncional" da morte não se casa com a atual sociedade focada no sucesso ${ }^{210}$.

Deve-se, porém, ter em mente, que essa situação de individualização da morte se acompanha de um gradual e claro viés autonomista nas decisões que envolvem o morrer. Pode-se pensar até que a privatização e a autonomia se imbricam, uma vez que, ao ser retirado de seu convívio social em situação tão delicada, a pessoa necessita de algum tipo de controle sobre seu próprio destino. Também não se pode olvidar que as diretivas antecipadas de vontade para o fim da vida nascem de seu gênero, as diretivas antecipadas de vontade latu sensu, por sua vez consagradas pelo princípio da autonomia, pilar da Bioética. Dentro de tudo que foi discutido nesse trabalho a respeito de autonomia e consentimento, as diretivas municiam o paciente de uma forma de expressão da vontade para ser utilizada em momento futuro, em que a capacidade de decisão esteja perdida. Evita, destarte, uma situação de insegurança para a equipe médica e seus familiares frente à tomada de decisões terapêuticas ${ }^{211}$.

Nessa linha, é certo que os métodos contemporâneos de combate às doenças contribuíram de forma evidente para o surgimento das diretivas. Ainda que haja um rol apreciável de patologias consideradas incuráveis, as formas de suporte à vida, derivadas da ciência médica, alargaram seu alcance. Esse fato, associado ao aumento de expectativa de vida e a crescente prevalência das doenças degenerativas consequentes ao aumento da idade dos pacientes, criou o pano de fundo para que surgissem as diretivas avançadas de vontade para o fim da vida ${ }^{212}$. A isso se soma o câmbio nas condições do processo da morte, descrito anteriormente.

209. KRESS, Hartmut, op. cit., p. 296.

210. "Na sociedade do século XX, cujos modelos eram competitividade, consumo ou acontecimento, o falecimento e a morte tornaram-se disfuncionais; mal puderam integrar-se no cotidiano, de forma que foram culturalmente reprimidos e, como tema, tornados tabu." KRESS, Hartmut, op. cit., p. 296.

211. Idem, p. 299. No mesmo sentido, Lucília Galha, em interessante obra de cunho testemunhal, assim introduz a questão: “(...) testamento vital com suporte legal - que assegura que cada pessoa possa decidir e deixar por escrito os cuidados de saúde que deseja ou não receber no caso de ficar incapaz de expressar sua vontade." GALHA, Lucília. Morte assistida - temos o direito de escolher a forma como morremos? os desejos e os receios de sete doentes portugueses confrontados com o fim, 2013, Introdução.

212. GONZÁLEZ, Miguel Ángel Sánchez. Testamentos vitais e diretivas antecipadas. In: RIBEIRO, Diaulas. A relação médico-paciente, velhas barreiras, novas fronteiras, 2010, p. 131. 


\section{Situações clínicas propícias às diretivas}

Há quatro situações em que as diretivas avançadas de vontade para o fím da vida, nos países em que elas já são uma realidade, podem ter aplicabilidade: doenças incuráveis e terminais, estado vegetativo prolongado e irreversível, situações emergenciais, e demência progressiva. Cada uma delas tem suas peculiaridades e são sobre estas características que, nesse ponto da pesquisa, iremos nos debruçar. É de se ressaltar que em alguns casos clínicos pode haver uma concomitância de duas situações elencadas acima, e.g. um doente com doença de Alzheimer avançada que sofre uma parada cardiorrespiratória.

\subsection{Patologias terminais}

Dentro do rol em que as diretivas avançadas de vontade para o fim da vida são aplicáveis, as doenças terminais talvez sejam o paradigma maior. Isso porque, nesses casos, parece mais palatável a abstenção de utilização de medidas invasivas para o suporte da vida, uma vez que o prognóstico do paciente é fechado. Aqui se insere harmonicamente o conceito de ortotanásia, e, a contrariu sensu, parece racional e esperado não empregar medidas médicas exageradas, vedando-se uma situação de distanásia. Nessa linha, a pessoa especifica no documento o desejo de não ser objeto de terapêuticas que apenas serviriam para prolongar o processo de morte, sem que haja alguma chance de cura ${ }^{213}$.

Ainda que haja certa imprecisão no conceito de doença terminal, já que a medicina não é ciência exata, pode-se admitir, para fins práticos, a condição terminal como "condição incurável causada por acidente ou doença, e que de acordo com uma avaliação médica razoável, produzirá morte dentro de seis meses, mesmo com uso de medidas de sustentação da vida compatíveis com o padrão de cuidados médicos",214.

213. MONAGLE, John F.; THOMASMA, David C. Health care ethics - critical issues for the $21^{\text {st }}$ Century, 2005, p. 93. A propósito, em um interessante e recente estudo prospectivo realizado em HongKong, Jean Woo observou que 88,4\% das pessoas idosas entrevistadas, com média etária de 82 anos, preferiria que no caso de doença terminal, o tratamento deveria visar seu conforto e o alívio da dor, mesmo que isso incorresse em eventual abreviação do tempo de vida. No mesmo estudo, 77,3\% dos idosos gostaria de permanecer em sua casa em seus últimos dias de vida, e $88 \%$ acharam uma ideia interessante a formalização de um documento que expressasse sua vontade com antecedência, nos moldes de uma diretiva avançada de vontade para o fim da vida, mesmo sem nunca terem ouvido falar do documento. WOO, Jean. Aging in Hong Kong - a comparative perspective, 2013, p. 247.

214. EDSEL, Ernest. The complete legal form book of living wills, 2009, p. 13. (tradução livre do autor) 
Não obstante, segundo boa parte dos pesquisadores a expressão "doença terminal" corresponde à situação clínica na qual, segundo o julgamento de um ou mais médicos, a morte sobrevirá em um "curto espaço de tempo", consequente a uma doença, e independerá de uma intervenção médica. Note-se que não há como escapar da falta de precisão do conceito $^{215}$.

Talvez a situação mais emblemática de enfermidades em certos casos incuráveis, com evolução previsível e com um bom grau de acuracidade, sejam as patologias de natureza oncológica. De fato, os variados tipos de câncer, por conta da moderna "medicina baseada em evidências", ensejam uma adequada previsibilidade com relação ao seu porvir. Isso permite que as equipes médicas instruam os pacientes e suas famílias de forma antecipada, o que acaba por tornar mais factível para o paciente assumir posturas de expressão de vontade enquanto ainda é uma pessoa capaz. O que, diga-se, está no próprio cerne das diretivas antecipadas de vontade. Tendo esse norte, o paciente adequadamente informado pode formalizar o documento das diretivas de forma mais específica, levando em consideração até o tempo previsto de resposta aos medicamentos $^{216}$. Em face dessa especificidade, há certa facilidade em dispor sobre quais procedimentos as equipes de suporte médico devem se abster de realizar ao se cruzar a linha da irreversibilidade prognóstica ${ }^{217}$. Ou seja, aqui estamos frente aos chamados casos "fáceis" 216 de decisão médica, em que se soma a presença de um documento escrito, que foi elaborado com detalhamento, associado a uma situação clínica em que a abstinência de adoção de tratamentos obstinados para a manutenção da vida é socialmente aceitável. A plena possibilidade de informação do paciente que vivencia a progressão de sua moléstia, e que tem a percepção da irreversibilidade permite confeccionar a diretiva antecipada de vontade com precisão ${ }^{219}$.

No tocante às doenças terminais, fica patente a importância, na arte médica atual, do que se convencionou chamar de medicina paliativa, ou seja, aquela que tem

215. OLICK, Robert. Taking advance directives seriously - prospective autonomy and decisions near the end of life, 2001, p. 23.

216. ROSENBAUM, Ernest H.; ROSENBAUM, Isadora. Everyone's guide to cancer supportive care - a comprehensive handbook for patients and their families, 2005, p. 481.

217. CARROL, Roberta. Risk management handbook for health care organizations, 2009, p. 276.

218. KING, Nancy M. P. Making sense of advance directives, 1996, p. 8. “(...) there is at least some societal agreement about "easy" cases involving terminally ill patients and refusal of invasive lifesustaining treatments like artificial ventilation, resuscitation, and chemotherapy. And there is a redundancy of reasoning about these cases as well: there are many good reasons to support the decision to stop treatment. Both patients' rights and patients' best interests can justify treatment withholding and withdrawal in these cases."

219. CARPER, Donald L.; McKinsey, John A.; WEST, Bill W. Understanding the law, 2008, p. 697. 
como escopo não a cura, mas o alívio dos sintomas que trazem desconforto ao paciente em fase tão desafiadora. As diretivas antecipadas vem ao encontro das propostas dos cuidados paliativos, agindo como facilitadores de seu emprego por parte das equipes de saúde ${ }^{220}$.

\subsection{Estados vegetativos persistentes}

Os estados vegetativos caracterizam, em uma avaliação neurológica das funções mentais gerais da consciência ("b110”) 221, um grau extremo de prejuízo dessas funções. De etiopatogenia muito variada, destacam-se aqui as síndromes pós-concussionais, cuja grande prevalência se fundamenta na ocorrência dos acidentes em geral ${ }^{222}$. Diferenciamse da morte cerebral por conta de que nesta há total e completa ausência de atividade cerebral, o que envolve alguma complexidade propedêutica ${ }^{223}$.

Nesse sentido, os estados vegetativos são, em regra, derivados de um estado comatoso, podendo ser transitórios ou persistentes. O coma, por sua vez, se caracteriza pela ausência absoluta de consciência por período superior a uma hora. No coma, tanto o mecanismo de despertar como a percepção própria e do ambiente, ambos compondo a consciência, se encontram ausentes. No estado vegetativo, por sua vez, o mecanismo de despertar está mantido, "persistindo no paciente a perda absoluta do conhecimento de si mesmo e do entorno, quer dizer, do conteúdo da consciência" ${ }^{, 224}$.

220. Nesse sentido: "A medicina paliativa (=atenuante) assiste pessoas que se encontram em um estado de incurabilidade como câncer, insuficiência de imunidade ou doenças neurológicas em estado adiantado. Diferentemente da medicina curativa dominante no cotidiano, a medicina paliativa não persegue o objetivo de uma cura. Ela tem como foco o acompanhamento humano na doença e da morte, na atenuação das dores, assistência sintomática física e devoção espiritual.” KRESS, Hartmut, op. cit., p. 327.

221. ORGANIZAÇÃO MUNDIAL DA SAÚDE. Classificação internacional de funcionalidade, incapacidade e saúde, 2001, p. 64.

222. SOUZA, Carlos Alberto Crespo de. Avanços em clínica neuropsiquiátrica, 2005, p. 39.

223. "O diagnóstico de morte cerebral é baseado na ausência de função cerebral (coma, ausência de resposta a estímulos, ausência de movimentação espontânea e ausência de posturas anormais) associada à ausência de função do tronco cerebral (apneia, pupilas fixas e não reativas, ausência de reflexos óculocafálico e óculo-vestibular, e de tosse). O teste da apneia confirma o diagnóstico de morte cerebral na ausência de movimentos respiratórios quando a $\mathrm{PaCO} 2$ for superior a $60 \mathrm{mmHg}$ durante oxigenação apneica. Os exames complementares podem incluir o eletrocardiograma (mostra traçado isoelétrico), Doppler transcraniano (picos sistólicos sem fluxo diastólico ou um padrão de fluxo reverberante), angiografia cerebral (ausência de circulação nas artérias encefálicas) e potencial evocado (mostra ausência de potenciais)." NÁCUL, Flávio et al. Manual de medicina intensiva, 2009, p. 104.

224. GHERARDI, Carlos R. Vida y muerte en terapia intensiva - estrategias para conocer y participar en las decisiones, 2007, p. 100. Ainda à guisa de conceituação, Collins e Weber: "Persistent Vegetative State (PVS): A chronic form of unconsciousness. PVS differs from coma in that the patient has sleepwake cycles, although the PVS patient lacks any awareness even when awake. In PVS the cerebral cortex does not function but the lower portion of the brain, the brain stem that controls vegetative function, is intact. PVS is virtually never reversible." COLLINS Jr., Evan R; WEBER, Doron. The complete guide to living wills - how to safeguard your treatment choices, 1991, p. 309. 
Foi justamente a discussão que envolveu dois casos emblemáticos da condição clínica do estado vegetativo persistente que impulsionou toda a doutrina norteamericana relativa à eutanásia e, em última instância, às diretivas antecipadas de vontade para o fim da vida. Os casos de Karen Ann Quinlan ${ }^{225}$ e de Nancy Cruzan 226 envolveram a opinião pública norte-americana e acabaram por trazer à tona questões médico-legais ainda inéditas à época, em um tempo em que a própria disciplina da Bioética ainda se encontrava embrionária. Desde então, mais atenção tem sido dada aos protocolos ético-profissionais que devem cercar estas situações, que por sinal tem sido cada vez mais comuns na medicina intensiva, bem como nas enfermarias que prestam assistência a patologias severas e a acidentados.

Ao contrário do que foi relatado em relação a doenças terminais, aqui há um grau maior de imprevisibilidade fática, já que e.g. um acidente que deixe sequelas neurológicas graves e culmine em estado vegetativo persistente é uma possibilidade palpável na vida moderna. O que denota a utilidade e até a necessidade de uma expressão prévia de vontade, bem documentada, antevendo esse risco $^{227}$.

\subsection{Quadros demenciais progressivos}

As doenças demenciais envolvem uma carga maior de polêmica, quando relacionadas às diretivas antecipadas de vontade, do que as condições clínicas abordadas nas linhas anteriores. A iniciar pelo próprio documento legal que intitula este estudo,

225. JECKER, Nancy S.; JONSEN, Albert R.; PEARLMEN, Robert A. Bioethics - an introduction to the history, methods, and practice, 2012, pp. 66 e ss. Karen Ann Quinlan, aos 21 anos de idade, foi atendida no setor de emergência de um hospital de Nova Jersey, Estados Unidos, em 1975, com um quadro clínico de coma, consequente a ingestão de álcool e barbitúricos. Foram tomadas medidas habituais de suporte da vida, tendo a paciente evoluído do coma para o estado vegetativo persistente. A família Quinlan, após cinco meses, requisitou o desligamento do aparelho respirador, uma vez que o prognóstico se configurava irreversível. A equipe médica se negou a tomar tal conduta, e o caso acabou por ser julgado na Suprema Corte do Estado de Nova Jersey, sendo a decisão final a de suspender as medidas que davam sustentação à vida de Karen, com fundamento na irreversibilidade do quadro clínico.

226. DRANE, James F. Clinical bioethics - theory and practice in medical-ethical decision making, 1994, pp. 104 e ss. Em 1982, aos 25 anos, Nancy Cruzan sofreu um acidente automobilístico em que foi arremessada de seu veículo, e ficou por alguns minutos com sua face submersa em uma poça de água. Por conta da situação de anóxia cerebral, posteriormente recebeu o diagnóstico de estado vegetativo persistente. Sua família requisitou que os procedimentos de suporte da vida fossem suspensos, o que foi acolhido pelo juízo de primeira instância do Estado de Missouri. Houve, porém, apelação à Suprema Corte de Missouri, que reverteu a decisão com base na falta de confiabilidade das alegações da família de que Nancy não gostaria de ser mantida nessa situação. Finalmente, a Suprema Corte dos Estados Unidos, em 1990, autorizou a retirada do tubo de gastrostomia responsável pela nutrição enteral da paciente, e ela faleceu em poucos dias.

227. GALLIN, John I., OGNIBENE, Frederick P. Principles and practice of clinical research, 2012, p. 129. 
pois nem todos os quadros demenciais, ainda que se trate daqueles progressivos, tem uma relação tão direta com a letalidade. Ou seja, aqui, em alguns casos, não se trataria de diretivas avançadas de vontade para o fim da vida, mas sim, das mais genéricas diretivas antecipadas de vontade sensu latu. Mesmo assim, cabe uma breve abordagem sobre esta situação na pesquisa, não só por ser cabível uma avaliação genérica em um estudo mais particularizado, mas também porque há alguma relação desses quadros com outros agravos da saúde progressivos. E, nesses casos, denota-se a eventual necessidade médico-ética das diretivas antecipadas de vontade, eis que o paciente, pela própria natureza da patologia, se torna incapaz.

Essa incapacidade nasce de suas próprias características clínicas. As demências, cujo exemplo mais comentado na atualidade talvez seja a doença de Alzheimer, se traduzem por graus variáveis de déficit cognitivo, e cuja velocidade de progressão também é variável. Segundo o DSM-IV, da American Psychiatric Association (1994), que regula as definições diagnósticas no âmbito da saúde mental, as demências são na verdade uma síndrome, cujos critérios comuns para inclusão envolvem a dificuldade cognitiva, e que geralmente, mas não sempre, incluem o prejuízo da memória ${ }^{228}$.

Nesse diapasão, configura-se como quase intuitiva a utilidade de um documento que expresse as vontades do paciente quanto a futuros tratamentos, e que seja elaborado enquanto ele ainda é capaz. Na prática, porém ocorrem alguns percalços. Um deles é o fato de que pessoas com prejuízo cognitivo moderado e demência precoce não elaboram diretivas antecipadas de vontade com frequência. Além disso, há alguns questionamentos ético-legais de um documento formatado nessa situação, já que as demências, por sua natureza, envolvem algum grau de despersonalização do paciente ${ }^{229}$. Isso será também ventilado, nessa pesquisa, quando abordarmos as limitações e as

228. “(...) Memory and one additional area of cognitive impairment, including aphasia, apraxia, agnosia, and executive dysfunction, are required to be affected according to common criteria (DSM-IV). There are other generic dementia criteria, including the ICD-10 criteria, which require that several domains are affected, and newer dementia criteria are being developed (i.e. DSM-V). Some criteria have not required memory impairment as a necessary condition for dementia, since it might not be prominently impaired in non-Alzheimer's dementias, and even occasional patients with Alzheimer's disease can exceptionally have relatively preserved memory." QUINN, Joseph F. Dementia, 2014, p. 1. No mesmo sentido, Ballard e Bannister, que chamam a atenção para os critérios do DSM-IV que envolvem o prejuízo para as atividades da vida diária. Também destacam que os critérios diagnósticos perpassam pela característica de progressividade da síndrome, o comprometimento de funções cognitivas elaboradas, e o prejuízo da função emocional e social. BALLARD, Clive; BANNISTER, Carol. Criteria for the diagnosis of dementia. In: Alistair, B.; O’Brien, J.; Ames, D. Dementia, 2005, p. 24.

229. KLEIN, E.; KARLAWISH, J. Ethical issues in the neurology of aging and cognitive decline. In: Bernat, J. L.; Beresford, R. Ethical and legal issues in neurology, 2013, p. 238. 
críticas ao instituto das diretivas antecipadas de vontade.

\subsection{Situações emergenciais}

Nesse tópico, certamente a situação-padrão são as ordens de não ressuscitação cardiorrespiratória, já tangenciadas anteriormente nessa dissertação. Ainda que possam compor o epílogo de qualquer das situações patológicas acima abordadas, as paradas cardiorrespiratórias podem se cristalizar como eventos inesperados e isolados, dentro de uma patologia cardiovascular silenciosa, por exemplo. Nesse quadro, ainda que possa parecer incomum, o paciente pode ter anteriormente externado sua vontade de não ser reanimado, documentado essa vontade e tornado seus entes próximos cientes de seu desejo.

Decerto esse tipo de preocupação de uma pessoa capaz pode ser motivado por uma série de experiências, grosso modo, aquelas vivenciadas em face de parentes e amigos que foram submetidos a procedimentos invasivos de reanimação. De qualquer forma, por uma "ordem de não-reanimação em ambiente extra-hospitalar" ${ }^{230}$, o sujeito pode deixar expresso que no caso de uma indicação de ressuscitação cardiorrespiratória fora de um aparato de saúde, as pessoas não devem efetuar o procedimento de reanimação.

Nessa trilha, o mesmo conceito pode ser estendido ao caso de um procedimento hospitalar, como uma cirurgia. Caso o paciente tenha documentado sua vontade de não ser submetido a procedimentos reanimatórios no intraoperatório, o anestesiologista, que é o responsável pela manutenção das condições hemodinâmicas do paciente durante o ato cirúrgico, poderia se abster de fazer a reanimação ${ }^{231}$. No entanto, outra linha doutrinária sustenta que a abstenção procedimental não cabe nesta situação, eis que em centro cirúrgico as condições de reanimação, incluindo aparato tecnológico e equipe treinada, são em geral ideais. Talvez uma abordagem mais racional, sustentada pelo "American College of Surgeons", fosse a avaliação da situação individual pela equipe cirúrgica, no sentido de efetuar ou não ao procedimento consoante a etiologia da parada cardíaca $^{232}$. Porém mesmo nesse caso pode haver lesão de preceito ético, já

230. CEBUHAR, Jo Kline. Last things first, just in case...the practical guide to living wills and durable powers of attorney for health care, 2006, p. 220.

231. BRITT, L.D.; TRUNKEY, Donald D.; FELICIANO, David V. Acute care surgery - principles and practice, 2007, p. 697.

232. Idem, ibidem. 
que, recorde-se, o paciente deixou expressa sua vontade de não-reanimação. Tudo acaba por dotar essa condição de uma labilidade e de uma dubiedade nada desprezível, que em tese pode causar tensão na equipe médica ${ }^{233}$ A única forma de mitigar o problema é a adequada informação do paciente e de sua família, previamente documentada, levando em conta o prognóstico individual e a real possibilidade de uma parada cardiorrespiratória $^{234}$.

\section{Aspectos extralegais}

Qualquer estudo vertical de um tema em Bioética não pode prescindir de uma abordagem extrajurídica, pela própria natureza dessa ciência contemporânea, plena de porosidade a valores sociais, muitos deles alheios a positivação. Assim, serão traçadas algumas linhas sobre esses aspectos. Pela vastidão dos assuntos, cada um deles por si só merecedores de inúmeras teses, o autor se penitencia a priori pela inevitável concisão. Porém, ao abordá-los ao menos sucintamente, tenta apartar, mesmo de maneira incompleta, a falha da omissão.

Com esse intuito, de início serão traçadas algumas considerações sobre conceitos religiosos relacionados ao assunto em tela. Mesmo considerando que vivemos sob normas, em tese, laicas, o ethos social denota uma evidente interface com valores religiosos, mormente em temas relacionados às condutas em face do processo de morrer.

A seguir, serão vislumbradas considerações sobre a Bioética em sentido genérico, incluindo algumas inter-relações com a moral passada e contemporânea. Tudo com o sentido de apresentar um delineamento mais sólido sobre as normas bioéticas específicas das quais esse trabalho trata.

233. “(...) From an ethical standpoint, there is no issue in stopping resuscitation efforts if valid information is presented that the patient or their surrogate decision maker does not want resuscitation. It must be pointed out, however, that medics are trained to "err on the side of life", unless there is a valid DNR (Do Not Resuscitate) form." SINGER, Peter A.; VIENS, A. M. The Cambridge textbook of bioethics, 2008, p. 472.

234. WEISS, Raul; DAOUD, EMILE G. Sudden cardiac death: heart failure clinics, 2011, p. 274. Os autores destacam a inviabilidade de proceder à terapêutica reanimatória agressiva em pacientes com mau prognóstico, ainda que isto deva ser previamente documentado por meio das diretivas antecipadas de vontade. 


\title{
5.1. As diretivas sob o viés religioso
}

\begin{abstract}
"Vou te contar como vejo essa história. No começo havia a árvore. Os humanos tinham um só desejo: subir o mais alto possível, onde as folhas da árvore tocavam as nuvens. Inventaram a escada, que funcionava bem. Um dia, um espertinho quebrou a escada, para ver no que dava. Não havia mais jeito de ir até o alto! Em todas as religiões, sempre há um espertinho que quebra a escada entre o céu e a terra. Depois chegaram os jardineiros para experimentar outros meios. Fazer a árvore crescer o mais alto possível, permitir que os homens subam nela. Não pararam de subir...,235
\end{abstract}

Em geral, a postura dos líderes religiosos é eivada de incertezas no que tange aos aspectos que envolvem as condutas médicas no fim da vida, muito em face da complexidade doutrinária-espiritual que envolve a temática. As diretivas antecipadas de vontade para o fim da vida não fogem a esta regra ${ }^{236}$ De fato, ao menos em solo nacional, com a honrosa exceção de poucos doutrinadores, como Leo Pessini, são muito raros os religiosos que se debruçam criteriosamente sobre os dilemas bioéticos.

Conforme Pessini e Barchifontaine, citando em sua obra o norte-americano Edmund Pellegrino:

“(...) no presente momento não encontramos ainda uma metodologia adequada para lidar com a crescente polarização que convicções autênticas trazem para os debates. De qualquer forma, devemos ser capazes de viver e trabalhar juntos, mesmo que nossas mais profundas convicções filosóficas sobre o certo e o errado estejam frequentemente em conflito.,237

Na mesma obra, desta feita citando o teólogo Hans Kung, Pessini lembra que as religiões, de forma geral, buscam respostas para as incertezas da humanidade, como os temas do sofrimento, amor, culpa, morte, os motivos que governam os destinos da humanidade e tantos outros. Também na religião as pessoas buscam apoio e conforto em momentos de solidão e de dor, buscando "uma felicidade duradoura, constante e eterna, a libertação de todo sofrimento, culpa e morte"238.

235. CLÉMENT, Catherine. A viagem de Theo - romance das religiões, 1999, p. 600.

236. Krohm e Summers comentam que "há uma considerável variação de atitudes" por parte das religiões em face das diretivas antecipadas, o que pode levar os leigos e os conselheiros religiosos a "visões

disparatadas". KROHM, Carol; SUMMERS, Scott. Advance health care directives - a handboook for professionals, 2002, p. 120.

237. PESSINI, Leo; BARCHIFONTAINE, Christian de Paul. Problemas atuais de bioética, 2008, p. 140. 238. Idem, ibidem. 
Nesse sentido, a maior parte dos estudos coloca a religião como benéfica para a saúde mental das pessoas ${ }^{239}$. Além disso, por constituírem o cerne dos valores de muitos indivíduos, seus conceitos devem ser respeitados no sentido da própria tutela da diversidade cultural entre os povos ${ }^{240}$. Importa lembrar que no Brasil há farta proteção constitucional às convicções religiosas ${ }^{241}$, o que pode e deve ser levado em consideração em face de decisões de cunho bioético.

Em sede do objeto deste estudo, parece evidente a necessidade de perquirir as convicções religiosas ao lidar com as diretivas antecipadas de vontade para o fim da vida. Isso porque não há como desvincular as expressões de vontade nelas inseridas dos valores individuais da fé. Esses, por sua vez, podem se chocar com algumas disposições das diretivas. Para algumas religiões, por exemplo, a suspensão de nutrição é vedada. Além disso, pode haver a percepção, para alguns credos, de que as diretivas antecipadas são um caminho aberto para a eutanásia ativa e o suicídio assistido, que se contrapõem cabalmente com várias religiões ${ }^{242}$.

Entretanto, principalmente em países onde já começa a haver uma razoável habitualidade no uso das diretivas antecipadas de vontade para o fim da vida (notadamente os Estados Unidos), alguns templos já começam a convidar profissionais médicos para ministrar palestras informativas sobre as diretivas ${ }^{243}$.

Sem a pretensão em particularizar profundamente a visão doutrinária de cada

239. KOLB, Patricia J. Social work practice with ethnically and racially diverse nursing home residents and their families, 2007, p. 180. A autora elenca alguns pesquisadores que abraçam essa tese: Chang, Noonan \& Tennstendt, 1998; Ellison, 1991; Matthews, Larson \& Barry, 1993; Pang, 1996; Pargament, 1998; Picot et al., 1997; Stuckey, 2001. Em viés dissonante, King \& Dein, 2001, que consideram a religião como intensificadora do stress.

240. Idem, ibidem.

241. Nesse quesito, José Afonso da Silva perfila os seguintes incisos do artigo $5^{\circ}$ da Constituição da República: a) inciso I: "homens e mulheres são iguais em direitos e obrigações, nos termos desta Constituição" - o apanágio do estado laico é a igualdade de tratamento, independente de credo religioso; b) inciso VI: "é inviolável a liberdade de consciência e de crença, sendo assegurado o livre exercício dos cultos religiosos e garantida, na forma da lei, a proteção aos locais de culto e as suas liturgias" - no caso dos valores bioéticos, há relação com a liberdade religiosa, pois essa se confunde com a própria liberdade espiritual; c) inciso VIII: "ninguém está privado de direitos por motivo de crença religiosa ou de convicção filosófica ou política, salvo se as invocar para eximir-se de obrigação legal a todos imposta e recusar-se a cumprir prestação alternativa, fixada em lei" - na mesma linha do inciso anteriormente citado, consagrando a liberdade religiosa. SILVA, José Afonso da. Comentário contextual à Constituição, 2010, pp. 66 e ss.

242. DOUKAS, David John; REICHEL, William. Planning for uncertainty - living wills and other advance directives for you and your family, 2007, Introduction. Na mesma direção, Vincent Barry, que destaca, porém, que as diretivas podem expressar desejos de assistência médica específica no sentido da salvaguarda da vida para algumas situações, não sendo portanto, em tese, oponíveis às religiões. BARRY, Vincent. Bioethics in a cultural context - philosophy, religion, history, politics, 2012, p. 99.

243. BENNETT, Richard G.; HALE, W. Daniel. Building healthy communities through medical-religious partnerships, 2009, section 11 - advance directives (examples of congregational programs). 
religião, por fugir do escopo dessa pesquisa, abordaremos breves tópicos doutrinários dos principais credos em face desse tema.

A visão do Cristianismo segue a premissa básica de que o homem foi criado à imagem e semelhança de Deus ${ }^{244}$, e como tal o corpo assume uma essência de sacralidade. O cristianismo em geral, incluindo aqui o catolicismo e as religiões evangélicas, repudia a eutanásia. A possibilidade de aceitação das diretivas avançadas de vontade, por seu turno, se vincula ao respeito aos dogmas católicos ${ }^{245}$.

Nessa linha, no âmbito do catolicismo, a encíclica Evangelicum Vitae, elaborada em 1995, durante o papado de João Paulo II, define a eutanásia como uma "ação ou omissão que por si causa a morte, com o propósito de eliminar o sofrimento", e a condena por representar um "falso perdão"246 . Entretanto, o próprio Papa João Paulo II enunciou que "a vida é um tesouro, e a morte um acontecimento natural" um lado mostra plena coerência com a vedação aos procedimentos eutanásicos, por outra dá margem interpretativa no sentido de censurar a obstinação terapêutica representada pela distanásia ${ }^{248}$.

Salta aos olhos que houve um câmbio no caminho percorrido na forma de encarar o processo da morte, desde a Idade Média, com um viés calcado na espiritualização $^{249}$, até os tempos contemporâneos, com um olhar secularizado e medicalizado.

244. O'ROURKE, Kevin D.; BOYLE, Philip J. Medical ethics - sources of catholic teachings, 2011, p. 3. 245. O'ROURKE, Kevin D.; BOYLE, Philip J., op. cit., p. 45. Nessa linha, os autores citam recente normativa a respeito de instituições de saúde católicas: "In compliance with federal law, a Catholic health care institution will make available to patients information about their rights, under the laws of their state, to make an advance directive for their medical treatment. The institution, however, will not honor an advance directive that is contrary to Catholic teaching. If the advance directive conflicts with Catholic teaching, an explanation should be provided as to why the directive cannot be honored. Source: United States Conference of Catholic Bishops, Ethical and Religious Directives for Catholic Health Care Services, $5^{\text {th }}$. Edition (Washington, DC: USCCB, 2009).

246. PETRINOVICH, Lewis. Living and dying well, 1996, p. 112.

247. BRITO, António José dos Santos Lopes de; RIJO, José Manuel Subtil. Estudo jurídico da eutanásia em Portugal, 2000, p. 135.

248. Em relação aos procedimentos de sustentação da vida atinentes a pacientes em estado vegetativo persistente, João Paulo II explicitou sua opinião afirmando, em março de 2004, durante o Congresso Internacional sobre "Tratamentos de sustentação da vida e estado vegetativo: avanços científicos e dilemas éticos", que nutrição e hidratação devem ser sempre fornecidos a esses pacientes. Isso porque essas medidas não devem ser consideradas procedimentos médicos, mas sim se inserem em uma obrigação de cunho moral. Porém considera que em casos específicos, em que a nutrição e hidratação não cumpram seus propósitos de forma adequada, e em que as terapêuticas analgésicas não surtam efeitos, os tratamentos podem ser descontinuados. TOLLEFSEN, Christopher. Artificial nutrition and hydration the new catholic debate, 2008 , p. 39.

249. Cf. SCHOTT, 2002, "o sacerdote reformista e professor na Universidade de Sorbonne, Jean de Gerson (1363-1429) (...) citou quatro etapas para o processo da morte espiritual:

- exortações (exhortationes): o moribundo deve subjugar-se à resolução onipotente de Deus e suportar pacientemente o sofrimento enviado por Deus; 
Essencialmente, outras religiões tradicionais não tem uma diretriz diversa do Cristianismo. Para o Judaísmo, que também veda a possibilidade da eutanásia, a questão que se coloca é determinar o momento em que o processo irreversível da morte se inicia $^{250}$. A partir dessa fase, os procedimentos terapêuticos são desestimulados, o que mais uma vez redunda na rejeição à distanásia, e em um acolhimento da ortotanásia e das diretivas antecipadas de vontade em face dessa possível situação clínica. No caso do Islamismo, a partir da "Terceira Conferência de Juristas Islâmicos", realizada em Aman, na Jordânia, em 1986, a maioria dos países que professa esse credo tem aceitado o conceito de morte cerebral, abandonando a definição mais antiga, baseada no mero exame físico ${ }^{251}$. Há vedação à eutanásia.

Observe-se que as três religiões acima abordadas (Cristianismo, Judaísmo e Islamismo) tem um cerne comum, o monoteísmo, basicamente acreditando no mesmo Deus, o "Deus de Abraão", e portanto "compartilhando essencialmente do mesmo código de moralidade" $" 252$.

Em contrapartida, o Hinduísmo tem uma doutrina completamente diferente, cuja crença se baseia no eterno renascimento de uma pessoa individualmente considerada. Assim, a morte física seria apenas o reinício de um novo ciclo, sendo cada uma destas fases oportunidades para uma gradual purificação do espírito. Para os fins desse estudo, importa considerar que a religião hinduísta tem uma visão muito restritiva em relação à autonomia, no sentido de que a pessoa (união de corpo, mente e espírito) é inserida dentro de um contexto que inclui necessariamente a família, a cultura e o ambiente ${ }^{253}$.

Ao mitigar a própria formação da vontade individual, isso obviamente terá repercussões em relação aos preceitos bioéticos, incluindo a possibilidade de formular uma diretiva antecipada de vontade.

- interrogações (interrogationes): o doente arrepende-se dos seus pecados e pede perdão a Deus;

- orações (orationes): deve implorar o suporte assistencial de Deus, da Virgem Maria, do Anjo da Guarda e especialmente dos padroeiros da morte, São Cristóvão e Santa Bárbara;

- instruções ao sacerdote (observationes) para a confissão e a extrema-unção." KRESS, Hartmut, op. cit, p. 292.

250. (...) a greater challenge is determining the moment when hope for continued life is lost and the process of death has begun. Jewish law is relatively clear that life is not to be taken before its time. It is equally clear that one is not to impede or hinder the death process once it has begun." GOLDSAND, Gary; ROSENBERG, Zahava R. S.; GORDON, Michael. Bioethics for clinicians: Jewish bioethics, 2001, p. 220. In: www.cmaj.ca

251. DAAR, Abdallah S.; KHITAMY, A. Bioethics for clinicians: Islamic bioethics, 2001, p. 62.

252. Idem, ibidem.

253. COWARD, Harold; SIDHU, Tejinder. Bioethics for clinicians: Hinduism and Sikhism, 2000, p. 1168. 


\subsection{As diretivas sob o viés bioético}

Em sucinta digressão histórica, é importante lembrar que Sócrates, em sua forma dialógica de expressar conceitos filosóficos, já pensava no médico como um provedor de assistência à saúde no melhor interesse do paciente. Em seus diálogos com Trasímacos, o filósofo grego pontuava que esse interesse deveria ser o norte da prática médica, e não interesses econômicos ou políticos, ainda que considerasse lícito que o médico auferisse proventos que lhe proporcionassem uma vida digna ${ }^{254}$.

Seu contemporâneo, Hipócrates, formulou, no século V A.C., os métodos de diagnosticar e de fazer prognósticos que iam além das meras profecias comuns à época. Isso lhe deu a ascendência técnico-profissional, sobre seus pares, que lhe permitiram divulgar diretrizes éticas. Estas ainda hoje servem de balizas para a prática médica, sendo a mais famosa o "Juramento de Hipócrates". Na esteira dessas balizas surgiu o conceito de iatros, trazendo uma atitude mais resolutiva do médico perante seu paciente, e afastando os antigos métodos de Empédocles, que visavam "ajustar as forças divinas no interesse de curar o corpo" ${ }^{\text {255 }}$. Para o que interessa neste trabalho, foi do termo iatros que derivou o vocábulo iatrogenia, que pode ser definida como “(...) afecção decorrente de uma intervenção do médico ou de seus auxiliares, seja ela certa ou errada, justificada ou não, mas da qual resultem consequências danosas para a saúde do paciente" ${ }^{256}$. Em análise última, foi da cristalização do conceito de iatrogenia que foi formulada a noção de não-maleficência, uma das bases da Bioética atual, e que prescreve a adequação dos métodos de tratamento no sentido de não causar um dano adicional ou reduzir o risco de causar esse dano ${ }^{257}$.

Nessa linha, os variados procedimentos que se perpetram em face do paciente internado em uma unidade de terapia intensiva, por exemplo, levam em seu bojo necessariamente uma carga de iatrogenia, vez que não são isentos de efeitos colaterais.

Além do que já foi discutido alhures neste texto em relação às questões que

254. KUCZEWSKI, Mark G.; POLANSKY, Ronald. Bioethics - ancient themes in contemporary issues, 2002, p. 141 e ss.

255. KUCZEWSKI, M. G.; POLANSKY, R., op. cit., p. 6.

256. PASSARELLI, Maria Cristina; CARVALHO, Flávio Pedreira de Freitas de. Farmacoterapia: iatrogenias. In: LOPES, Antônio Carlos (editor), Diagnóstico e tratamento, volume 2, p. 797.

257. JONSEN, Albert R.; SIEGLER, Mark; WINSLADE, William J. Clinical ethics - a practical approach to ethical decisions in clinical medicine, 2010, p. 11. 
envolvem o consentimento e a autonomia, cabe aqui uma complementação em relação aos valores morais que um documento como as diretivas antecipadas de vontade para o fim da vida carrega. Nesse sentido, não só as particularidades éticas individuais de cada paciente, mas também os valores da cultura à qual pertencem devem ser levados em consideração ao se confeccionar uma diretiva antecipada de vontade ${ }^{258}$.

Ao analisar os pressupostos culturais inseridos no âmago das diretivas antecipadas de vontade para o fim da vida, Miguel Ángel González traça uma interessante perspectiva histórica ${ }^{259}$. As diretivas, segundo ele, vem imbuídas de traços culturais inerentes à civilização norte-americana, não por acaso a primeira sociedade a acolher mundialmente esse tipo de documento. Essas características seriam: a) o individualismo atomista, segundo o qual a sociedade está formatada para servir o indivíduo, no sentido de "maximizar a liberdade e a realização individual"; b) o contratualismo, em que sempre há uma ideia implícita de contrato permeando qualquer tipo de relação humana, e a relação médico-paciente não seria uma exceção a essa regra; c) consumismo e empresarialismo, nivelando a prestação de saúde a uma relação de consumo como outra qualquer, e dando ênfase à questão econômica em detrimento de conceitos humanitários; d) pluralismo, segundo o qual as "diferentes tradições morais" devem ser toleradas; e) procedimentalismo ético, vigente em uma sociedade perpassada por valores morais plurais, e portanto voltada para o mero procedimentalismo individual; f) autonomia, da qual as diretivas de vontade seriam o corolário. Ao descrever essas características culturais, o bioeticista de Madri, em um viés crítico, acusa o seu contraponto, enunciando que essas concepções podem levar a uma medicina excessivamente contratual, individualizada e, ao demonizar o paternalismo médico, demasiadamente aberta em relação às opções de condutas ${ }^{260}$.

Nesse diapasão, a concepção de uma medicina excessivamente técnica é errônea. O médico trabalha sob o respaldo da chamada "medicina baseada em evidências", filtrada de estudos clínicos bem conduzidos ${ }^{261}$, e além disso atua sob os liames das

258. “(...) compouning the differences in overall awareness of advance directives are fundamental differences in values and the ways in which death and illness are approached. It is here, in a mass of different guiding norms, punctuated by different customs and practices, overlain with a thick layer of disparate languages, that the thorniest difficulties in engaging in advance care planning lie." SWOTA, Alissa Hurwitz. Culture, ethics, and advance care planning, 2009, p. 25.

259. GONZÁLEZ, Miguel Ángel Sánchez. Testamentos vitais e diretivas antecipadas. In: RIBEIRO, Diaulas Costa. A relação médico-paciente: velhas barreiras, novas fronteiras, 2010, p. 115 e ss.

260. Idem, ibidem.

261. JONSEN, A. R.; SIEGLER, M.; WINSLADE, W. J., op. cit., p. 24. 
normas bioéticas. Por óbvio o médico, assim como o juiz, não utiliza apenas seu aprendizado técnico, e nem deve fazê-lo, em sua tomada de decisões, até porque a medicina não é ciência exata ${ }^{262}$. Em sua atividade, o médico, incorporado dos conceitos culturais inerentes a qualquer ser humano ${ }^{263}$, deve procurar facilitar a tomada de decisões por parte de seu cliente, sem ser paternalista, e respeitando o valor da autonomia. Há claros reflexos desse axioma em relação à concepção de uma diretiva antecipada de vontade para o fim da vida, no sentido de, ao reconhecer sua grande utilidade, ela dever ser necessariamente acompanhada por um médico em sua feitura. Mais além, a medicina deve entender a ausência do documento, muitas vezes, não como mera omissão do paciente, mas como fruto da própria autodeterminação da pessoa ${ }^{264}$.

262. A esse respeito, discorre Genival Veloso de França: “(...) não se pode admitir serenamente que a medicina abra mão da intuição, das teorias fisiopatológicas consagradas e da experiência clínica pessoal, pois não existe nenhuma análise metodológica nem prova científica aprimorada que não possua como ponto de partida a vivência e observação individual na prática profissional. E mais: a medicina baseada em evidências não é receita pronta e acabada na orientação de todos os procedimentos médicos." FRANÇA, Genival Veloso de. Os riscos da medicina baseada em evidências. In: Bioética, n. 1, v. 11, 2003, p. 30.

263. Nesse sentido: “(...) Clinician-patient communication in end of life issues does not operate outside of the context of culture. Culture can be defined as the socially transmitted body of values, beliefs, behaviors, social and political institutions, arts, crafts and science that are shared by a given group of people. This concept of culture can also be applied to groups who share characteristics other than geography or ethnicity." BUKEN, Nuket Ornek; BALVESEN-ODABASI, Aysun. Physicians' attitudes at the end-of-life: a cross-cultural evaluation. In: Medicine and law, volume 32, number 4, December 2013, p. 550 .

264. "Ao se preservar a possibilidade do sujeito de se autodeterminar, a ele é garantido o "ser si mesmo" nas relações com os outros, situação esta que tem como suporte sua própria identidade. Por isso, a conexão entre a identidade pessoal absoluta e a identidade pessoal relativa possibilita perceber que a diversidade enriquece a humanidade, pois, não obstante a natureza humana ser sempre a mesma, ela se realiza de forma exclusiva em cada ser humano." ALVES, Cristiane Avancini. A conexão entre a autodeterminação e a formação familiar na esteira do princípio da responsabilidade. In: MARTINSCOSTA, Judith; MÖLLER, Letícia Ludvig. Bioética e responsabilidade, 2009, p. 141. 


\section{CAPÍTULO VI. TÓPICOS DE DIREITO COMPARADO}

Em Bioética, talvez de forma mais evidente do que em outros ramos do direito, deve-se ter em mente que a análise comparada dos ordenamentos não pode se apartar do contexto cultural de cada país, e nesse sentido a busca de um ideal de uniformidade soa utópica $^{265}$. No entanto, não há como prescindir desse ferramental, ainda mais em face de um instituto no qual o Brasil não tem positivação, e em que a normativa ética ainda engatinha $^{266}$.

Além disso, valores éticos em geral, e bioéticos em particular, a priori são dotados de conceitos que, se não universais, pelo menos tendem a algum grau de harmonia, fundamentada no que se convencionou chamar de jusnaturalismo. Nesse sentido, o direito comparado propõe "reconduzir a diversidade à unidade" ${ }^{, 267}$, de forma a colmatar o direito pátrio e preencher suas lacunas.

No que concerne ao objeto deste estudo, o direito comparado permite a mensuração normativa de "um dos mais controversos focos da reflexão jurídica" na atualidade, segundo Silvia Zullo e Matteo Galletti ${ }^{268}$.

\section{Estados Unidos}

A análise deste tema no direito norte-americano se reveste de uma relevância especial, uma vez que os Estados Unidos foi o primeiro país a adotar o instituto das diretivas antecipadas de vontade para o fim da vida, ainda nos idos da década de 1970. Disso decorre que este país possui uma expertise evidente no tema, fundada na

265. DURAND, Guy; PERROTIN, Catharine. Contribution à la reflexion bioéthique - dialogue FranceQuébec, 1991, p. 257.

266. Nesse sentido, comentando em termos de direito como um todo, Sophie Monnier ressalta a imprescindibilidade do direito comparado: "En ce qu'il met en lumière les dissemblances et les rapprochements des systèmes juridiques, il constitue un précieux instrument de connaissance du droit. Par delà la diversité des systèmes juridiques, il permet de dégager un jus commune, suscetible de rallier jusnaturalistes et positivistes. Il est associé à un néo-jusnaturalisme dans la mesure où il est degagé par induction à partir des différents droits positifs. Prenant as source dans le droit positif, il traverserait les systèmes juridiques, ce qui lui conferment un caractère transcendant." MONNIER, Sophie. Les comités d'éthique et le droit - éléments d'analyse sur le système normatif de la bioéthique,2005, p. 339.

267. “(...) la visée pratique attribue une function normative au droit comparé. Dans cette perspective, il incombe au droit comparé de ramener la diversité à la unité; le droit comparé est ainsi instrumentalisé pour parvenir à une harmonisation du droit à défaut d'une uniformisation." MONNIER, Sophie, op. cit., 2005, p. 340.

268. GALLETTI, Matteo; ZULLO, Silvia. La vita prima della fine: lo stato vegetativo tra etica, religione e diritto, 2008, p. 130. 
aplicação real das diretivas em vários casos, e que pode ser preciosa no estudo doutrinário aplicável em solo nacional, em que, ao contrário, só recentemente o assunto começa a ser dissecado. Ainda que a doutrina norte-americana atinente a esse problema não caiba nas breves linhas deste subitem do trabalho, é fato que a maior parte da pesquisa bibliográfica ao longo desta dissertação bebeu das fontes norte-americanas.

Historicamente, o percurso das diretivas antecipadas de vontade para o fim da vida nos Estados Unidos se confunde com a própria história do consentimento informado, do qual é, em última análise, uma modalidade. No século XIX, o consentimento informado era requerido, em juízo, apenas em casos nos quais fosse considerado parte integrante e ordinária do próprio tratamento médico ${ }^{269}$. Um dos casos pioneiros na jurisprudência, nesse sentido, foi Carpenter v. Blake ${ }^{270}$. O início do século $\mathrm{XX}$ assistiu ao descortinar do consentimento informado, em solo norte-americano, como forma de avaliação processual em casos de suspeita de erro médico ${ }^{271}$.

Já a partir da metade do século XX, e agora não mais abordando o consentimento informado sensu latu, mas sim o objeto desta pesquisa, Miguel González delimita duas fases no processo de implementação das diretivas antecipadas de vontade para o fim da vida nos Estados Unidos. O primeiro, em fase chamada de pré-legislativa, compreende o período anterior a 1976, sendo o marco dessa etapa a proposta, no ano de 1967, do testamento vital, feita pela Sociedade Americana para a Eutanásia ${ }^{272}$. Nessas diretivas, o paciente autorizava a suspensão de medidas para a manutenção da vida.

Após poucas tentativas frustradas de promulgação de leis em alguns estados americanos, a Califórnia surge como pioneira, em 1976, colocando em vigor lei sobre morte natural, que só viria a ser substituída por norma federal da qual falaremos a seguir.

269. $C f$. o historiador Martin Pernick, do século XIX. Pernick inseria o consentimento, nessa época, não como parte do princípio da autonomia, mas sim como ligado à beneficência. Ou seja, era mera peça da terapêutica, nos casos em que fosse aplicável. Isso durou até a virada para o século XX, em que o consentimento, por conta da valorização do princípio da autonomia, experimentou uma mudança de viés. FADEN, Ruth R.; BEAUCHAMP, Tom L. A history and theory of informed consent, 1986, p. 117.

270. Em apertada síntese, o médico tratou o cotovelo deslocado de uma paciente com um método não convencional; segundo a corte, houve negligência do facultativo a respeito dos cuidados que a paciente deveria seguir para a cura completa. Considerou, também, que a autorização documental que a paciente deu para que o médico abandonasse o caso partiu de uma informação errônea, por parte do profissional, de que a evolução estava correndo a contento. FADEN, Ruth R.; BEAUCHAMP, Tom L., op. cit., p. 118. 271. Idem , p. 120.

272. GONZÁLEZ, Miguel Ángel Sánchez, op. cit., p. 112. 
Na metade dos anos 1970, além de a tecnologia médica ter experimentado um evidente progresso nas técnicas de suporte avançado da vida ${ }^{273}$, o caso Karen Ann Quinlan, já abordado anteriormente, foi o divisor de águas para uma era em que a opinião pública norte-americana exacerbou a discussão sobre a possibilidade de uma pessoa não poder expressar sua vontade em face de uma situação hospitalar de mau prognóstico. Após alguns casos de igual potencial polêmico, como os de Nancy Cruzan, decidido pela Suprema Corte dos Estados Unidos em 1990, surgiu no ano seguinte a norma de âmbito federal denominada "Patient Self Determination Act" (PSDA) 274. Aprovada pelo Congresso dos Estados Unidos em 5 de novembro de 1990, e entrando em vigor em $1^{\circ}$ de dezembro de 1991, o fulcro da lei foi dotar o paciente de capacidade de decisão em face dos tratamentos a que poderia ser submetido, em qualquer local de prestação de serviços à saúde. O exercício desse poder passa pela informação de seus direitos, a saber: o de poder recusar algum tipo de tratamento, o de poder apresentar suas diretivas antecipadas de vontade seguindo os liames das leis estaduais, e o de ser informado sobre as políticas da instituição na qual está sendo tratado a respeito da suspensão de medidas de suporte à vida ${ }^{275}$. Assim, o PSDA é o corolário, em solo estadunidense, do princípio bioético da autonomia. O documento, em regra, indaga sobre a preexistência de um curador para cuidados de saúde, tipo de responsável legal sobre o qual comentaremos com detalhes mais à frente nessa dissertação. Nessa linha, em tese o PSDA teria uma essência de universalidade, a qual perpassa pela adequada informação dos pacientes sobre as questões contidas no documento, em prol do correto exercício da autonomia ${ }^{276}$.

Entretanto, fica evidente, logo em um primeiro olhar, que ocorrem alguns entraves para a aplicabilidade prática do PSDA. Em primeiro lugar, os pacientes, de forma geral, não preparam com antecedência uma diretiva antecipada, mesmo levando em consideração que vivem em uma nação com ampla tradição em uma medicina de base contratual $^{277}$.

273. GODKIN, M. Dianne. Living will, living well - reflections on preparing an advance directive, 2008 , p. 8.

274. ULRICH, Lawrence P. The Patient Self-determination Act-meeting the challenges in patient care, 1999, p. 230.

275. Idem, p. 9.

276. CLOTET, Joaquim. Bioética - uma aproximação, 2006, p. 73 e ss.

277. A despeito da pretensa obrigatoriedade do PSDA nos equipamentos de saúde, o que em tese estimularia a feitura das diretivas antecipadas de vontade, menos de $20 \%$ dos norte-americanos as prepara. RICH, Ben A. Strange bedfellows: how medical jurisprudence has influenced medical ethics and medical practice, 2001, p. 78. 
O segundo problema é que há uma apreciável variabilidade em relação às questões formais, ou seja, de que forma as instituições de saúde oferecem as informações contidas no PSDA a seus pacientes. Levando em consideração que a norma tem um fulcro educativo, importa muito o método de apresentação da informação, já que disso depende a eficácia do documento. Alguns locais de prestação de serviços de saúde apresentam um rol de direitos do paciente em forma de vídeos, outros o fazem em impressos próprios ${ }^{278}$, porém o conteúdo raramente é fornecido de forma personalizada e adaptada à capacidade de compreensão de cada paciente. O ideal é que essas informações, das quais serão registradas as opções do paciente, sejam ofertadas pelo próprio médico responsável pela assistência ao paciente. Na prática, no entanto, esse procedimento poucas vezes é factível, muito por conta da falta de disponibilidade de tempo das equipes médicas ${ }^{279}$.

Além disso, questiona-se, na atualidade, até que ponto o PSDA é relevante para a tomada de decisões médicas ${ }^{289}$, ou, dito de outra forma, até que ponto tem função meramente perfunctória.

Nessa linha, a sensação de insatisfação com o PSDA abriu caminho para abordagens alternativas em face da expressão de vontade dos pacientes. Uma delas, reconhecida em 34 estados norte-americanos e no Distrito de Columbia, é conhecida como documento "Five Wishes". Nele, o foco é o planejamento das decisões concernentes à assistência à saúde, tendo como parâmetro as opções do paciente que passam pelos seus próprios valores de vida ${ }^{281}$. Voltaremos posteriormente a esse tema.

Outra maneira de suprir a ineficácia do PSDA, usando uma ferramenta não legal, mas sim doutrinária, seria a iniciativa de cada instituição de saúde confeccionar padrões (guidelines) adaptáveis a variadas situações clínicas em que houvesse a possibilidade de o paciente se tornar incapaz de tomar decisões. Nesse sentido, os administradores

278. BERGER, Arthur S. When life ends - legal overviews, medicolegal forms, and hospital policies, 1995 , p. 76.

279. (...) the surgeon should at first assume that patients with these clinical conditions are capable of participating in the informed consent process and ought to be encouraged to do so. The range of therapeutic options that are tipically available to such patients can make the disclosure step of this process quite challenging for the busy surgeon." McCULLOUGH, Lawrence B.; JONES, James W.; BRODY, Baruch A. Surgical ethics, 1998, p. 130.

280. GONZÁLEZ, Miguel A. S., op. cit., p. 115.

281. Os cinco desejos explicitados pelo paciente são: “1) a pessoa escolhida pelo paciente para decidir pelos cuidados dele quando ele não for capaz de faze-lo; 2) o tipo de tratamento médico que o paciente deseja ou não deseja; 3) o quão confortável o paciente deseja estar; 4) como o paciente deseja ser tratado; 5) o que o paciente quer que seus entes queridos saibam." YOUNG, Carolyn; KOOPSEN, Cyndie; FARB, Daniel. End of life care issues guidebook, 2005, p. 112. (tradução livre do autor) 
dos equipamentos de sáude norte-americanos deveriam perquirir, junto à sua populaçãoalvo, uma ideia de preferência sobre a conduta médica nas situações de suporte da vida $^{282}$.

É certo, no entanto, que, em que pese suas imperfeições e incompletudes, o PSDA trouxe em seu bojo o escopo de privilegiar a autonomia do paciente, trazendo uma maior ênfase a um importante instituto de cunho bioético. Nesse sentido, o fato de que as instituições de saúde devessem confeccionar esse tipo de documento fez com que a sociedade norte-americana voltasse os olhos para a questão das diretivas antecipadas de vontade. Destarte, diversamente de carrear uma ideia de obrigatoriedade, o que pragmaticamente se revelou completamente falha, o escopo do PSDA foi estimular a feitura das diretivas por parte da população ${ }^{283}$. O que, frise-se, já é bastante louvável em termos de ética médica.

\section{Espanha}

Diferente dos Estados Unidos, em que a moralidade é permeada de um viés liberal e individualista, mais próximo do ideal de autonomia, e que, por essa razão, acolheu confortavelmente a essência das diretivas antecipadas de vontade, na Europa

282. Essa postura nasceu da constatação, por meio de pesquisas populacionais (CBS - New York Times), de que havia uma frontal discrepância, nos Estados Unidos, entre a conduta dos médicos e a vontade dos pacientes na ausência de uma diretiva antecipada de vontade. Enquanto os procedimentos médicos eram tendentes à preservação da vida por parte dos médicos, $85 \%$ da população não gostaria de ser alimentada por um tubo em caso de coma sem atividade cerebral. Outra pesquisa realizada em pessoas não hospitalizadas em Boston chegou a resultados semelhantes, indicando que $80 \%$ não gostaria de ser submetida a medidas de suporte à vida (como ressuscitação cardiopulmonar, ventilação mecânica e nutrição artificial) em caso de "inconsciência permanente, demência ou doença terminal". GRECO, Peter J. et al. The Patient Self-Determination Act and the future of advance directives. In: JECKER, Nancy S.; JONSEN, Albert R.; PEARLMEN, Robert A. Bioethics - an introduction to the history, methods and practice, 1997 , p. 327. Cabe lembrar, por outro lado, que a sociedade norte-americana, apesar de ter um histórico liberal no que concerne às relações jurídicas, é imbuída de valores conservadores na forma de encarar o processo da morte; prova disso é o fato de que apenas no Estado de Oregon a eutanásia é descriminalizada. McDOUGALL, Jennifer Fecio; GORMAN, Martha. Euthanasia: a reference handbook, 2008, ,p. 26.

283. GRECO, Peter et al., op. cit., p. 324. Ainda nesse sentido de incentivo, o próprio presidente Barack Obama declarou que ele e sua esposa fizeram uma diretiva antecipada de vontade para o fim da vida, segundo entrevista publicada na mídia no ano de 2009: "You don't want somebody else making those decisions for you. So I actually think it's a good idea to have a living will. I'd encourage everybody to get one. I have one; Michelle has one. And we hope we don't have to use it for a long time, but I think it's something that is sensible." CONNOLLY, Ceci. The Washington Post. Obama takes personal approach in AARP speech. In: The Seattle Times, July 29, 2009. www.seattletimes.com, acesso em 30/04/2014. 
ocidental houve uma latência maior para essa aceitação. Talvez porque nas terras de Espanha, nação representativa dessa região europeia, a ética é impregnada fortemente de valores do Catolicismo, e mesmo da filosofia estoicista ${ }^{284}$, o que acaba por se colocar no caminho inverso de um instituto de cunho marcadamente personalista.

Mesmo assim, o artigo 9 da Convenção de Oviedo (vide Anexo 2), cujo enunciado respalda o respeito à vontade expressada anteriormente pelo paciente em face de tratamentos médicos, pavimentou a trilha das diretivas antecipadas de vontade em solo espanhol ${ }^{285}$. Tendo como antecedente um projeto de lei da Catalunha (Emenda 123 do Grupo Parlamentario Catalán) ${ }^{286}$, e após diversas modificações legislativas, o artigo 11 da Lei 41/2002 formaliza as "instrucciones previas". Assim foi feita sua redação:

Artículo 11

Instrucciones previas

1. Por el documento de instrucciones previas, una persona mayor de edad, capaz y libre, manifiesta anticipadamente su voluntad, con objeto de que ésta se cumpla en el momento en que llegue a situaciones en cuyas circunstancias no sea capaz de expresarlos personalmente, sobre los cuidados y el tratamiento de su salud o, una vez llegado el fallecimiento, sobre el destino de su cuerpo o de los órganos del mismo. El otorgante del documento puede designar, además, un representante para que, llegado el caso, sirva como interlocutor suyo con el médico o el equipo sanitario para procurar el complimiento de las instrucciones previas.

284. Nesta temática, Miguel González ensina, com base de pesquisa em M. Zambrano ("La cuestión del estoicismo español") que "o estoicismo espanhol introduziu o tema da meditação sobre a morte e a volatilidade das iniciativas mundanas e acompanhou o apogeu do império espanhol, sendo o modelo de filosofia que predominou na alma hispânica. Sua influência pode ser detectada em quatro atitudes culturais que atualmente continuam muito difundidas: primeira, uma peculiar atitude de desprezo para com os bens materiais de consumo. É uma atitude que considera a simplicidade uma virtude máxima, sendo contrária à mentalidade consumista moderna; segunda, o estoicismo consagrou uma certa forma de entender a felicidade, que deve ser buscada nos estados de ânimo e nas relações com as demais pessoas e não no gozo das comodidades materiais; terceira, contribuiu para desenvolver uma atitude anti-utilitarista peculiar, que pode chegar, inclusive a desinteressar-se por soluções práticas; (...) quarta e última, o estoicismo esteve acompanhado de uma peculiar desconfiança para o "eu" individual a para o privado." Continua o catedrático madrilenho afirmando que "a importância dessas diferenças culturais sobre o tema das diretivas antecipadas se faz patente quando temos em conta que a mentalidade consumista e individualista está entre seus pressupostos e quando recordamos que a defesa dos direitos dos pacientes foi promovida pelas associações de consumidores." O professor espanhol ressalta, porém, que a atitude estoica se coloca paradoxalmente na mesma direção das diretivas ao dar respaldo à questão da dignidade da vida e da morte, e ao entender a futilidade terapêutica como um valor individualista. GONZÁLEZ, Miguel Ángel Sánchez, op. cit., pp. 124-125.

285. LUELMO, Andrés Domínguez. Derecho sanitario y responsabilidad médica - comentarios a la Ley 41/2002, de 14 de noviembre, sobre derechos del paciente, información y documentación clínica, 2007, p. 416.

286. LUELMO, Andrés Domínguez, op. cit., pp. 409 e ss. 
2. Cada servicio de salud regulará el procedimiento adecuado para que, llegado el caso, se garantice el cumplimiento de las instrucciones previas de cada persona, que deberán constar siempre por escrito.

3. No serán aplicadas las instrucciones previas contrarias al ordenamiento jurídico, a la lex artis, ni las que no se correspondan con el supuesto de hecho que el interesado haya previsto en el momento de manifestarlas. En la historia clínica del paciente quedará constancia razonada de las anotaciones relacionadas con estas previsiones.

4. Las instrucciones previas podrán revocarse libremente en cualquier momento dejando constancia por escrito.

5. Con el fin de asegurar la eficacia en todo el territorio nacional de las instrucciones previas manifestadas por los pacientes y formalizadas de acuerdo con lo dispuesto en la legislación de las respectivas Comunidades Autónomas, se creará en el Ministerio de Sanidad y Consumo el registro nacional de instrucciones previas que se regirá por las normas que reglamentariamente se determinen, previo acuerdo del Consejo Interterritorial del Sistema Nacional de Salud.

Esta lei ainda foi passível de complementação pela normativa federal (Real Decreto 124, de 2 de fevereiro de 2007) criando o "Registro Nacional de Instrucciones Previas". A norma de Estado foi regulada por leis estaduais nas comunidades de Andalucia, Aragón, Baleares, Canarias, Cantabria, Castilla - La Mancha, Castilla y León, Cataluña, Comunidade de Madrid, Murcia, Navarra, País Basco, La Rioja e Comunidade Valenciana ${ }^{287}$. Importa também considerar que o artigo 11 da referida lei se harmonizou com o artigo 27 do "Código de Ética y Deontología Médica de la Organización Médica Colegial”, de 1999, não se configurando nenhuma forma de antinomia. Em suma, nos 3 incisos do citado artigo 27 do Código de Ética, há vedação à distanásia e estímulo à ortotanásia, seguindo as modernas diretrizes bioéticas que tem como objeto o bem-estar do paciente no processo de morte. Também está expresso neste artigo a vedação à eutanásia, ainda que haja projetos de lei na Espanha que visem despenalizar os atos eutanásicos, suprimindo o artigo 143.4 do Código Penal espanhol $^{288}$.

287. LUELMO, Andrés Domínguez, op. cit, pp. 409 e ss.

288. Nesse sentido: Proposición de Ley Orgánica, de 14 de junho de 2002, proposto pelo Grupo Parlamentario de Izquierda Unida; e também Proposición de Ley de 25 de maio de 2001, apresentada pelo Grupo Parlamentario Mixto. 
Ainda que haja uma razoável formatação jurídica das diretivas antecipadas de vontade para o fim da vida no ordenamento jurídico espanhol, chama a atenção o fato de as legislações das províncias autônomas, com exceção daquela da região de Murcia, tem uma definição desviante da Lei 41/2002 em relação às diretivas. Nesse sentido, por exemplo, falta concretude quanto aos requisitos pessoais necessários para confeccionar uma diretiva antecipada ${ }^{289}$. E, tal como ocorre nos Estados Unidos, a regulação não reverte no desiderato maior de eficácia da norma. No caso espanhol, ainda padecendo do agravante da falta de tradição do instituto no país, o que acaba por dificultar sua utilização nos aparelhos de saúde ${ }^{290}$. A falta de êxito das diretivas antecipadas de vontade para o fim da vida na Espanha "contrasta com o fervor legislativo que despertaram"291. Nesse sentido pode servir de interessante baliza para nosso país, no sentido de questionar até que ponto interessa concretizar uma lei, tendo como fundamento um instituto que carece de efetividade.

\section{Portugal}

Na mesma Europa Mediterrânea da Espanha, Portugal apenas recentemente promulgou lei sobre as diretivas antecipadas de vontade para o fim da vida. Aprovada em 16 de julho de 2012 por unanimidade, após seis anos de debate, a lei 25/2012 regulariza o testamento vital, o procurador para cuidados de saúde, e cria o Registro Nacional de diretivas avançadas ${ }^{292}$.

A lei portuguesa tem algumas peculiaridades: estabelece, para que seja eficaz, a assinatura de um médico dando respaldo e prévia informação às decisões expressas no documento pela pessoa maior e capaz; exige que haja registro em cartório; fixa a validade do documento como sendo de cinco anos, a partir do momento da assinatura $^{293}$; por fim, estabelece a nomeação de um procurador para cuidados de saúde.

289. BLANCO, Mariano Casado. Aspectos éticos y legales de las instrucciones previas, 2010, p. 142. 290. JÄÄSKELÄINEN, Federico de Montalvo. Muerte digna y Constituición: los límites del testamento vital, 2009, p. 171.

291. Idem, p. 171: "La escasa implantación obedece a que su elaboración es muy dificil exigiendo una amplia información técnica para su correta redacción, establezca instrucciones de difícil aplicación futura por una falta de identidad entre el supuesto de hecho previsto y el realmente acaecido. Además, el cumplimiento de las instrucciones plantea serios problemas a los profesionales sanitarios ante la dificultad de identificar claramente la voluntad del paciente respecto al supuesto de hecho previsto al otorgalas y su correspondencia con la situación clinica en la que se encuentra en el momento de su aplicación."

292. PEREIRA, André Dias. Living will and health care proxy - the portuguese legal situation. In: Medicine and law, volume 32, number 4, December 2013,pp. 497-498.

293. Idem, pp. 500-501. 
Assim que foi promulgada, a Lei 25/2012 gerou dúvida doutrinária fundamentada no fato de a vontade expressa do autor ter que ser imperativamente seguida pelas equipes de saúde, ou se se trata de mera "consideração da vontade da pessoa"294. André Pereira, da Universidade de Coimbra, afirma que há duas tendências distintas na doutrina portuguesa a partir da promulgação da lei: uma delas reza que a norma é de seguimento obrigatório; a outra, ao contrário, afirma que a lei tem apenas um efeito indicativo ${ }^{295}$.

Além disso, ao estabelecer que as diretivas antecipadas de vontade sejam assinadas perante um escrivão, em cartório, ocorre certa burocratização do processo; se por um lado isso traz uma maior segurança em face do teor da diretiva na possibilidade de o paciente futuramente se tornar incapaz, por outro retira em demasia o valor de uma expressão de vontade que não siga esses estritos liames burocráticos ${ }^{296}$.

Quanto à compatibilidade da Lei 25/2012 com o ordenamento jurídico português, que o legislador houve por bem deixar expresso no próprio enunciado da norma, vale lembrar que há criminalização da eutanásia (artigo 24 do Código Penal português) e do suicídio assistido (artigo 134) ${ }^{297}$. Isso retira a possibilidade de potencial extensão da lei a casos, por exemplo, de eutanásia passiva, o que, por sua vez, pode ensejar certo temor das equipes médicas em aplicar as diretrizes da referida lei.

\section{Itália}

As discussões sobre as condutas médicas em relação ao final da vida somente entraram em pauta na Itália na década de 1990, um atraso em relação ao restante da Europa que certamente foi influenciado pela forte presença do catolicismo na moralidade do povo italiano. Esse paradigma começou a ser demolido quando, por decreto de 1990 do Primeiro-Ministro, foi criado o Comitê Nacional Italiano de Bioética, instância governamental que congrega especialistas em temas bioéticos e

294. A esse respeito, o presidente do Conselho Nacional para as Ciências da Ética e da Vida, Miguel Oliveira e Silva, afirmou, em entrevista concedida à imprensa, que "É pena que os deputados não tenham sido mais explícitos, que não tenham explicado se respeitar tem um caráter vinculativo ou meramente indicativo." FONSECA, Sofia. Lei do testamento vital precisa de clarificação. In: DNPortugal, 15 de agosto de 2012. www.dn.pt, acesso em 02/05/2014.

295. PEREIRA, André Dias, op. cit., p. 498.

296. Idem, p. 500.

297. MOREIRA, Sara Leitão. Brief notes on the Portuguese criminal regime of homicide upon request of the victim and physician assisted suicide. In: Medicine and law, volume 32, number 4, December 2013, pp. 525 e ss. 
de ética médica ${ }^{298}$.

Também nessa época, a opinião pública italiana foi mobilizada de forma marcante a partir do caso emblemático de Eluana Englaro, uma jovem que entrou em estado vegetativo persistente, consequente a um acidente de carro em Lecco, no dia 18 de janeiro de $1992^{299}$. O pai de Eluana requisitou judicialmente a suspensão da alimentação da filha, o que foi negado pelo Tribunal de Apelação de Milão em 1999, e pelo tribunal de Cassação em 2005. Novo pedido de julgamento levou à autorização para suspensão da hidratação e concessão da paciente, pelo Tribunal de Apelação de Milão, em 9 de julho de 2008. Eluana faleceu em Udine, em 9 de fevereiro de 2009, após dezessete anos em estado vegetativo.

O drama de Eluana Englaro trouxe à tona a discussão sobre a eutanásia na Itália, e de maneira concomitante, a questão das diretivas antecipadas de vontade para o fim da vida. Isso porque, no caso das diretivas, um dos fundamentos para que os tribunais negassem, de início, a suspensão das medidas de suporte à vida de Eluana, foi o fato de que não havia documentação expressa da paciente, quando capaz, expressando sua vontade em relação à situação em que se encontrava. Nesse sentido, a Corte de Cassação, em julgado de 16 de outubro de 2006, enunciou que deveria haver "clara e convincente evidência, fornecida pelo representante da paciente e baseada no conhecimento do estilo de vida da paciente, sua personalidade e convicção de que ela não desejaria ser mantida viva por meios artificiais" ${ }^{, 300}$.

Nesse diapasão, há que se reportar a dois artigos da Convenção de Oviedo (ou Convenção sobre os direitos do homem e biomedicina), de 1997, já referida em linhas anteriores. $\mathrm{O}$ artigo 6 declara que no caso de o paciente não poder expressar o consentimento, não deve ser instituído um tratamento se este não lhe resulte em algum benefício. Nesses casos, o consentimento deve ser dado por seu representante legal. E o artigo 9, que versa sobre desejos previamente expressos pelo paciente em face de uma intervenção médica. Aqui a discussão se volta ao fato de a Convenção de Oviedo ter

298. VESHI, Denard. Ethical and legal issues in cases of withdrawing treatment from an incompetent patient in Italy. In: Medicine and law, volume 32, number 4, December 2013, p. 577.

299. GALOFARO, Francesco. Eluana Englaro: la contesa sulla fine della vita, 2009, pp. 13 e ss. O traumatismo da segunda vértebra cervical, concomitante a um coma profundo, resultou em um estado clínico em que Eluana respirava sem a ajuda de aparelhos, e mantinha o ciclo sono-vigília. Sua alimentação e hidratação eram feitos artificialmente, e ela respondia a estímulos por meio de reflexos simples, não relacionados à consciência. Segundo Carlo Alberto Defanti, neurologista que fez o seguimento de Eluana, houve uma perda de conexão entre o córtex cerebral e o tronco cerebral, de forma que o primeiro não podia receber estímulos e nem comandar o aparelho locomotor. "O tronco cerebral, por sua vez, continuava a funcionar, sendo prova disso a presença da respiração espontânea".

300. VESHI, Denard, op. cit., p. 582. 
insculpido no artigo 9 a expressão "intervenção médica", o que suscita discussão doutrinária no sentido de considerar os métodos de nutrição e hidratação em situações de assistência ao paciente no fim da vida como sendo tratamento, no sentido estrito, ou intervenção médica, de forma mais ampla. Quer dizer, se considerarmos a instituição de nutrientes e fluidos como intervenção médica, e não tratamento médico, isso retiraria a pecha de "encarniçamento terapêutico" desses métodos de manutenção da vida ${ }^{301}$. O que, em tese, daria uma certa fundamentação doutrinária aos que advogam a manutenção desse tipo de procedimento, ou seja, as vozes que se põem contra a suspensão dessas condutas.

Desse caldo ético-jurídico, talvez o que seja mais marcante, e que pode servir como filtro para a análise do instituto em questão, por conta da tateante experiência italiana, seja o que Denard Veshi, bioeticista da Universidade de Bolonha, assim sumarizou:

\footnotetext{
“(...) as diretivas antecipadas assumem uma grande importância, porque estas poderiam ser a única forma de aumentar a autonomia do paciente, ou, como no caso Englaro, de entender a vontade do paciente. Além disso, as diretivas antecipadas atenuam a distinção entre cuidados básicos e tratamento médico, ou entre tratamento proporcional e excessiva invasividade médica. Mais além, deve ser notado que o conceito de "efetiva vontade" não deve ser cronologicamente limitado ao futuro próximo, mas sim que deve ser considerado o último desejo do paciente ${ }^{302}$.
}

Nesse sentido, é importante ressaltar que o artigo 32 da Constituição Italiana declara o direito à saúde, o que em tese poderia fundamentar a autonomia dos pacientes em recusar algum tipo de tratamento. Na Itália, ainda não está pacificada a questão da moralidade e da legalidade de suspender o tratamento de um paciente que não tenha capacidade. Também permanece irresolvida a dúvida sobre a cogência das diretivas antecipadas de vontade em relação às atitudes médicas ${ }^{303}$.

301. GALOFARO, Francesco, op. cit., p. 96. Nesse sentido, ainda acerca do caso Eluana Englaro, também VESHI, Denard, op. cit., p. 582: “(...) As it can be understood, based on the difficulty of the issue, the Court did not conclude whether artificial nutrition and hydration are medical treatment or basic care."

302. Cf. Lecaldano, E., Bioetica. Le scelte morale, p. 59; e Giunta, F., Diritto di morire e diritto penale. I termini di una relazione problematica. Rivista Italiana del diritto e della procedura penale, p. 108. In: VESHI, Denard, op. cit., p. 582. (tradução livre do autor)

303. Idem, p. 584. 


\section{Inglaterra e País de Gales}

O Mental Capacity Act (MCA), de 2005, foi o instrumento legal que habilitou pessoas capazes para a possibilidade de futuramente poderem decidir sobre seus tratamentos de saúde, em caso de se encontrarem incapazes. Com validade na Inglaterra e no País de Gales, o MCA prescreve que as diretivas devem ser escritas e testemunhadas. Além disso, as possibilidades atinentes ao tratamento devem estar expressamente previstas no documento ${ }^{304}$.

Nos moldes dos ordenamentos ético-legais de outros países, o MCA também prevê um procurador de cuidados de saúde para decisões que não estejam expressas de forma específica nas diretivas, o que seria uma segunda abordagem em face das decisões de doentes incapazes. Como o procurador deve atuar no "melhor interesse" do paciente, uma peculiaridade na Inglaterra e no País de Gales, nesse tópico, é a destituição do procurador pela Corte de Proteção. E nos casos em que o paciente não tenha instituído um procurador, é possível apelar para a Corte de Proteção para que esta estipule um deputado que tome as decisões concernentes à saúde da pessoa que está em estado de incapacidade ${ }^{305}$.

Uma das dificuldades que afloram com a normatização das diretivas, regulada pelo MCA, é a possibilidade de sua invalidade no caso de a pessoa "ter feito algo que seja inconsistente com a prévia recusa de tratamento" ${ }^{\text {306 }}$. Outro complicador é a exigência estrita de caracterização das circunstâncias de tratamento, o que acaba por tornar as diretivas engessadas e passíveis de perda de eficácia plena.

Os atos médicos em face do fim da vida no Reino Unido são eticamente regulados por um documento de 2010, do UK General Medical Council, denominado "Tratamento e cuidados no fim da vida: boas práticas na tomada de decisões"307.

304. LINCOLN, Nadina B. et al. Psychological management of stroke, 2012, p. 217. Sobre esse tópico, Robert Blank elenca os requisitos necessários para uma diretiva antecipada de vontade válida no Reino Unido: “(...) uma diretiva antecipada é um documento atestando que a pessoa a quem se refere recusa-se a ser submetida a algum tratamento ou a um conjunto de tratamentos sob circunstâncias específicas. Desde que o documento esteja com redação clara, aplicável nas circunstâncias, e que foi feito por um paciente enquanto estava competente, e que tenha sido apropriadamente informado sobre suas opiniões e as consequências do documento, então ele será válido como se fosse uma recusa feita ao momento do tratamento." ASHCROFT, Richard. Death policy in the United Kingdom. In: BLANK, Robert (ed.). Endof-life decision making: a cross-national study, 2005, p. 208. (tradução livre do autor)

305. Idem, p. 218.

306. STOPPE, Gabriela. Competence assessment in dementia, 2008, p. 76.

307. VENTURA, Carla A. A. et al. Rethinking ethical and legal issues at the end of life in the UK and Brazil: a role for solidarity? In: Medicine and law, volume 32, number 4, December 2013, p. 483. 
Segundo esse documento ético-legal, os médicos devem se pautar por cinco princípios: "igualdade e direitos humanos; presunção em favor do prolongamento da vida, presunção de capacidade; maximização da capacidade de tomar decisões; e benefício integral". Note-se que especialmente o segundo princípio, que invoca a presunção em favor do prolongamento da vida, pode ter marcantes efeitos no caso de uma diretiva antecipada de vontade que não tenha seguido os parâmetros necessários regulados pela norma, ou em que o médico julgue que a vontade previamente expressa não é aplicável naquela determinada circunstância.

Também nessa linha, e relacionado ao princípio da igualdade, vale relatar um interessante caso de 2002 (Pretty v. UK). A Sra. Pretty, com incapacidades motoras, requereu suicídio assistido, alegando que, como o suicídio não é criminalizado no Reino Unido, a negação do auxílio ao ato suicida de uma pessoa que não pudesse fazer movimentos suficientes para concretizar o ato, violava o princípio da igualdade, discriminando as pessoas fisicamente incapacitadas ${ }^{308}$. A decisão da Corte foi negar o suicídio assistido, tendo como fundamentação o fato de não haver justificativa, na lei, para distinguir a capacidade de se suicidar entre os que são fisicamente capazes de fazêlo e os que não o são. Além disso, o ato resvalaria, para o Tribunal, na eutanásia, vedada no Reino Unido ${ }^{309}$.

\section{Holanda}

Ao considerar as diretivas antecipadas de vontade para o fim da vida como tendo uma relação muito próxima com a eutanásia, o que motivou a abordagem doutrinária do início desta dissertação, torna-se evidente que um país com visão liberal em relação a esse tema merece um olhar diferenciado.

A Holanda ocupa uma posição de vanguarda em face da eutanásia e do suicídio autorizado pelo paciente, desde que em 10 de abril de 2001 o Parlamento holandês promulgou norma que despenalizou esses atos ${ }^{310}$. A partir de então, a lei da eutanásia declara que o procedimento é factível dentro de certos liames legais, que incluem

308. VENTURA, Carla A. A. et al, op. cit., p. 491.

309. FOSTER, Steve. Human rights and civil liberties, 2008, p. 61.

310. COHEN-ALMAGOR, Raphael. Euthanasia in the Netherlands - the policy and practice of mercy killing, 2004, p. 2. 
procedimentos médico-administrativos específicos. Dentre estes, a supervisão, ao longo de todo o processo, por um comitê público composto de um médico, um advogado e um especialista em bioética. O médico tem um poder discricionário decisivo em cada caso, precisando estar convicto de que o ato se justifica naquela situação clínica particular. $\mathrm{O}$ paciente, por sua vez, deve ser exaustivamente informado de todas as alternativas possíveis em face de seu status médico, estando o ato estritamente encaminhado no caso de o paciente aceita-lo e requisita-lo, por achar que não há outro caminho viável para mitigar seu sofrimento. Além disso, ao menos um médico independente, que não esteja ligado ao seguimento prévio do paciente, deve examiná-1o ${ }^{311}$. Vale chamar a atenção para dois aspectos peculiares da lei da eutanásia holandesa: primeiro, o fato de que a autonomia do paciente é exercida de forma plena e madura; segundo, a substituição, após a promulgação da lei, do promotor público pelo comitê público a que nos referimos acima, o que soterra de vez o enfoque penal da questão.

As indicações da eutanásia na Holanda, de início vocacionadas a pacientes terminais, estenderam-se aos casos eticamente mais desafiadores, como os de portadores de demências. Aqui, há um evidente percalço por conta da perda de autonomia ${ }^{312}$. Pragmaticamente, é justamente essa a realidade que pode desvelar a utilidade das diretivas antecipadas de vontade.

Entretanto, há que se perceber que o sentido das diretivas na Holanda é bem diferente da essência do instituto nos Estados Unidos. O motivo disso é a própria dinâmica da assistência médica, que segue rumos diferentes se compararmos as duas nações. Se em território norte-americano a medicina, no seu aspecto relacional, é carregada de impessoalidade, o que ressalta o caráter contratual da atuação médica, na Holanda a assistência à saúde em regra é provida por médicos de família, que conhecem o histórico clínico e mesmo os valores pessoais de sua clientela ${ }^{313}$. Assim, ainda que as diretivas antecipadas na Holanda tenham forte fundamentação como forma de expressão da vontade do paciente que não é mais capaz, sua carga legal é menor do que nos Estados Unidos. Nessa linha, as diretivas também não são cogentes, preservando a discricionariedade do facultativo ${ }^{314}$.

311. COHEN-ALMAGOR, Raphael, op. cit, p. 2.

312. Idem, p. 72.

313. SWOTA, Alissa Hurwitz. Culture, ethics and advance care planning, 2009, pp. 17 e ss. 314. Idem, ibidem. 


\section{Bélgica}

Como a Holanda, a Bélgica tem uma postura liberalizante e descriminalizadora vis-à-vis a eutanásia. Desde 28 de maio de 2002, a eutanásia é legalizada na Bélgica, sendo a maior parte dos casos relacionados a câncer terminal. A maior parte das pessoas que se submeteram à eutanásia estavam capazes, e apenas uma pequena porcentagem $(2,1 \%)$ se baseou na expressão da vontade por meio de uma diretiva antecipada ${ }^{315}$. A norma belga define eutanásia como sendo composta por cinco elementos: “(a): uma ação; (b) cometida por um terceiro; (c) a ação deve ser intencional; (d) a pessoa em questão (isto é, o paciente) deve morrer como consequência da ação; (e) a pessoa em

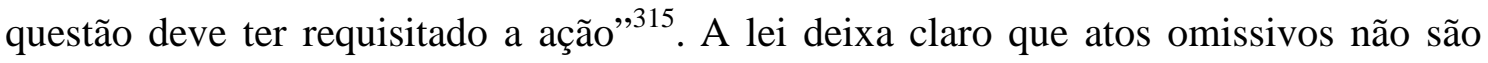
subsumíveis a ela, assim como condutas médicas concernentes a alívio da dor; mesmo que as drogas tenham duplo efeito e contribuam para a abreviação da vida do paciente, também estão apartadas da lei.

Formalmente, uma diretiva antecipada de vontade para o fim da vida na Bélgica pode ser feita por qualquer pessoa capaz maior de idade, ou menor emancipada. O documento vale como autorização para a eutanásia desde que siga alguns requisitos de aplicabilidade: o paciente deve sofrer de uma condição clínica grave e incurável, causada por uma doença ou por acidente; deve estar em estado de inconsciência; sua condição seja considerada irreversível dentro do que foi definido pela ciência médica ${ }^{317}$. O documento fica aos cuidados de um representante legal, que também tem a atribuição de informar a equipe médica sobre o teor da diretiva. Não há possibilidade de esse representante ser o médico assistente do paciente, e nem qualquer pessoa da equipe médica. A validade do documento é de cinco anos, e pode ser revogada a qualquer tempo. Porém, casos especiais em que o fato desencadeante da situação clínica ocorreu menos de cinco anos após a assinatura da diretiva, ainda que a requisição da eutanásia supere o período de cinco anos, poderão ser aceitas. Outro requisito é que o documento seja feito perante duas testemunhas, sendo pelo menos uma delas sem interesse material na morte do paciente. Por fim, a lei prevê uma situação de impossibilidade de o paciente assinar o documento, podendo expressar sua vontade perante testemunhas ${ }^{318}$.

315. ACTON, Ashton Q. Advances in terminal care research and application, 2012, p. 24.

316. NYS, Herman. Medical law in Belgium, 2010, p. 125.

317. Idem, p. 127.

318. Idem, ibidem. 
Na Bélgica a lei da eutanásia não é vinculante para o médico, no sentido de ele não ser obrigado a realiza-la. O que significa, por óbvia consequência, que as diretivas antecipadas de vontade, na linha dos outros países que analisamos nas linhas anteriores, também não o são ${ }^{319}$.

\section{Suíça}

O debate sobre as diretivas antecipadas de vontade para o fim da vida se iniciou, na Suíça, na década de 1970, de forma concomitante com a percepção de que os tratamentos altamente especializados nas unidades de terapia intensiva poderiam carrear um alto grau de agressividade para com os pacientes ${ }^{320}$. A partir de 1976, e com subsequentes modificações em 1981 e 1995, a Academia Suíça de Ciências Médicas regulou as condutas que deveriam nortear as diretivas antecipadas de vontade em sua relação com a eutanásia ${ }^{321}$.

A substância das diretivas sofre variações de acordo com as normas de cada cantão suíço. De forma geral, elas norteiam os cuidados com pessoas moribundas, e são o canal para a expressão de suas vontades, seja para suprimir os tratamentos, seja para mantê-los. Ultimamente, tem havido maior ênfase nos aspectos extralegais das diretivas antecipadas de vontade na Suíça, no sentido daquilo que elas representam como canal de expressão de valores individuais para as situações do final da vida ${ }^{322}$.

A Suíça se encontra na peculiar situação de ter a eutanásia como ilegal, porém o suicídio assistido ser legalizado. Com fulcro nessa legislação, foi criada a Sociedade Dignitas em Zurique, uma instituição facilitadora do suicídio assistido que chamou a atenção do mundo, a ponto de fomentar o chamado "turismo suicida" para o local ${ }^{323}$.

319. NYS, Herman, op. cit., p. 131.

320. BONDOLFI, Alberto. The recent debate on advance directives in Switzerland. In: Salute e società the pre-chosen death: end of life arrangements and instructions, X, n. 1/2011, p. 157.

321. Idem, p. 158. Nesse aspecto, o autor pontua que a sociedade suíça tem um olhar generoso em relação à eutanásia, ainda que esta seja ilegal, considerando o procedimento como uma forma de alívio do processo de falecimento.

322. Idem, ibidem. Por sinal, na opinião de Bondolfi, um olhar não restrito aos quesitos legais, em face das diretivas, é preferível a uma visão estritamente legalista.

323. EVANS, Abigail Rian. Is God still at the bedside? The medical, ethical, and pastoral issues of death and dying, 2011, p. 206. 


\section{República Tcheca}

As diretivas antecipadas de vontade são novas na legislação desse país. Seu ingresso no ordenamento jurídico tcheco teve como fundamento a Convenção de Direitos Humanos e Biomedicina, tal como outros países europeus. Em solo tcheco, a Convenção foi ratificada, resultando na Seção 36 do "Act on Healthcare Services". Como em outros Estados europeus, o artigo $9^{\circ}$ da citada Convenção, ao explicitar que "os desejos anteriormente expressados, relativos a intervenções médicas, por um paciente que não está, à época da intervenção, em condições de expressar suas vontades devem ser levados em consideração", mostra a ausência de força cogente do instituto. Por esse motivo, há quem o critique, alegando que a ausência de vinculação da conduta médica poderia esvaziar o instituto ${ }^{324}$. Ou seja, nada que seja contrastante em relação aos aspectos polêmicos das diretivas que se observam em outros lugares da Europa, e também nos Estados Unidos da América.

No entanto, há que se ponderar a fragilidade jurídica do médico ao obedecer a uma diretiva antecipada de vontade que expresse a autorização para suspensão de medidas de manutenção da vida, pois a validade do documento pode ser questionada em juízo, partindo da hipótese de falta de capacidade do consenciente ${ }^{325}$. O que, novamente, também fundamenta críticas às diretivas alhures.

De qualquer forma, é interessante frisar que as modificações legais na República Tcheca, em face dos procedimentos médicos atinentes ao fim da vida, ocorreram dentro do fluxo de mudanças políticas do fim do século XX, o que mostra o quão sensíveis ao ambiente político e cultural são os valores bioéticos ${ }^{326}$. Isso também demonstra a porosidade das normativas éticas em relação às tendências internacionais, principalmente em Estados que passaram por flagrantes cisões e rearranjos políticos, como foi o caso da nação tcheca.

324. PETERKOVÁ, Helena. Previously expressed wishes in the Czech Republic - a missed chance of the czech legislator. In: Medicine and Law, n. 4, v. 32, December 2013,pp. 429 e ss.

325. PETERKOVÁ, Helena, op. cit., p. 438: "In practice, however, the physician may always face the risk that the validity of the previously expressed wish will be questioned, for instance, because when the patient wrote the previously expressed wish, he/she could not be legally capable to such an (irrational) legal action as a result of mental disorder, or because it can be inferred that if the patient had known about his/her situation, what the doctor knows now, he/she would never have spoken (sic) the previously expressed wish and would never have refused the treatment."

326. DORON, Israel; SODEN, Ann M. (ed.). Beyond elder law - new directions in law and aging, 2012, p. 4. 


\section{Austrália}

As diretivas antecipadas de vontade são respaldadas na Austrália, na maior parte de seus estados e territórios (três estados e dois territórios), sendo consideradas verdadeira extensão do direito de autodeterminação. Este, por sua vez, encontra embasamento na common law ${ }^{327}$.

Há, porém, diferenças importantes entre os estados no que tange às diretivas ${ }^{328}$. Em Vitória, por exemplo, as diretivas só são aplicáveis em relação a uma situação clínica da qual o paciente já padecia quando firmou a diretiva antecipada. No Território do Norte as diretivas, mesmo podendo ser feitas a qualquer tempo, só adquirem eficácia em face de uma doença terminal, definida como "enfermidade, trauma ou degeneração que leva a morte iminente e da qual não há prognóstico razoável de recuperação temporária ou permanente.” Em Queensland, a eficácia das diretivas antecipadas para o fim da vida surge da incapacidade do paciente, desde que a enfermidade seja considerada incurável, a manutenção da vida seja incompatível com as boas práticas médicas, e que o prognóstico seja fechado.

Quanto à cogência do documento, os tribunais da Austrália se dividem. As diretivas antecipadas de vontade, sensu latu, podem ser sede de ação por lesão, sancionável por indenização por parte do médico, sendo exemplo disso a administração de sangue, por parte do facultativo, para paciente testemunha de Jeová que antecipadamente havia expressado a vedação ao procedimento ${ }^{329}$. Por outro lado, a execução de procedimentos reanimatórios em paciente que previamente havia firmado sua recusa a eles não foi sancionada, ainda que o prolongamento da vida tenha culminado em um acidente vascular cerebral no dia seguinte à ressuscitação, com paralisia parcial até a morte do paciente, dois anos depois ${ }^{330}$.

O fato é que as diretivas antecipadas de vontade na Austrália, sejam as relativas ao fim da vida, seja aquelas aplicáveis aos tratamentos em geral, mas

327. STEWART, Cameron. Advance directives: disputes and dilemmas. In: FRECKELTON, Ian; PETERSEN, Kerry (ed.). Disputes and dilemmas in health law, 2007, p. 38.

328. Idem, pp. 43 e ss.

329. Cameron Stewart cita, a esse respeito, o caso Malette v. Schulman, de 1994, que resultou na condenação a indenização de $\$ 20.000$, mesmo sem ter ocorrido lesão física na acepção técnica do termo. Op. cit., pp. 45-46.

330. Idem, pp. 46-47. Isso se refere ao caso Anderson v. St. Francis - St. George Hospital. Note-se que aqui a lesão foi evidente, porém o tribunal entendeu que não houve claro nexo de causalidade entre o derrame cerebral e a manutenção da vida, e que, além disso, a manutenção da vida não poderia ser considerada um "dano compensável". 
principalmente as primeiras, ainda se ressentem de falta de respaldo cultural, o que acaba por retirar muito de sua força e aplicabilidade. Além disso, não há sanção cominada para sua não observância, o que, para alguns, se traduz em uma mitigação de seus efeitos ${ }^{331}$.

\section{Ghana}

Ghana foi elencada no rol de tópicos de direito comparado deste estudo por dois motivos: primeiro, para servir de exemplo do tema em questão no tocante a um Estado africano, em que vicejam os problemas atinentes a uma nação pobre; segundo, porque em Ghana há um relevante contraste entre o que a lei permite, em face da eutanásia, e o que é efetivamente praticado, e aqui o país africano se aproxima do que ocorre em várias outras nações. Tudo matizado por uma conjuntura cultural e religiosa de peso $^{332}$.

A Constituição de Ghana, de 1992, em seu artigo 13, tutela a vida humana e proíbe a eutanásia, o que torna passível de sanção penal uma equipe médica que pratique o ato de abreviar a vida de um paciente, mesmo que esteja em estado vegetativo persistente ${ }^{333}$. Entretanto, o mesmo artigo veda o tratamento desumano ou degradante, ou seja, que ofenda a dignidade humana, e nesse sentido se configura o choque entre dois bens jurídicos no mesmo artigo, no que tange à eutanásia. Isso porque alguns procedimentos de manutenção da vida, por sua natureza invasiva e protraimento ao longo do tempo, podem ser considerados similares à tortura. Frise-se que esse confronto valorativo em sede constitucional também ocorre em ordenamentos de outros países.

No Código Penal do país também se pode observar esse mesmo tipo de ambiguidade, ainda mais evidente do que na Constituição ${ }^{334}$. Aqui sobressai a questão do consentimento por parte do paciente como exculpante de criminalização do médico que praticar eutanásia, no artigo 29 , enquanto na mesma codificação, na seção 42, há exclusão do consentimento como causa de justificação de crime por parte das equipes de saúde.

331. STEWART, Cameron, op. cit., p. 47: "Given the lack of civil and criminal responses to breaches of advance directives, it could be argued that there is a real danger that the right to make an advance directive will become a right without a remedy."

332. OWUSU-DAPAA, Ernest. Euthanasia, assisted dying and the right to die in Ghana: a socio-legal analysis. In: Medicine and Law, v. 32, n. 4, December 2013, p. 587.

333. OWUSU-DAPAA, Cameron, op. cit., p. 591.

334. Idem, pp. 595 e ss. 
Mesmo com essas indefinições legais, tem sido dado certo respaldo, nos tribunais ganeses, da questão da boa-fé nos atos médicos que procurem mitigar o sofrimento de pacientes terminais, ainda que possam, como efeito colateral, abreviar a vida desses doentes. Nessa linha, ainda que persista a visão tradicional, fulcrada em valores religiosos e culturais, de que a vida deve ser mantida a qualquer custo, surgem novos ventos doutrinários que dão respaldo à autonomia ${ }^{335}$. Estes podem, em tese, abrir caminho, em um segundo momento, às diretivas antecipadas de vontade para o fim da vida.

\section{Turquia}

A Turquia tem uma tradição cultural paternalista em relação às atitudes médicas em face de seus pacientes, o que acaba por mitigar a possibilidade de concretização das diretivas antecipadas de vontade para o fim da vida. Uma vez que a vontade dos pacientes tem pouco respaldo, a autonomia, fruto da vontade, não se cristaliza. Entretanto, começa a ocorrer uma lenta e gradual mudança nesse paradigma, a partir do "Regulation of Patient Rights", de 1998. Indo na contracorrente da ótica paternalista, essa norma regulatória abre caminho para a utilização das diretivas em um contexto de assistência ao fim da vida ${ }^{336}$.

A esse respeito, os bioeticistas turcos Buken e Balvesen-Odabasi, em interessante estudo comparativo do ordenamento turco em face dos Estados Unidos, Japão e Arábia Saudita, pontuam que há um entrave para o pleno exercício da autonomia em território turco. Isso porque o ethos cultural do país não respalda o direito de informação do paciente em relação às suas patologias, colocando nas mãos da família dos doentes, e mais das vezes dos próprios médicos, a capacidade decisória total no tocante aos procedimentos médicos. Por certo a aceitabilidade das diretivas, nesse contexto, deve passar por uma paulatina transformação desse viés cultural ${ }^{337}$.

335. OWUSU-DAPAA, Cameron, op. cit., p. 596.

336. GUVEN, T. Advance directives in Turkey's cultural context: examining the potential benefits for the implementation of patient rights. In: Bioethics, 2010; 24(3): pp. 127 e ss.

337. BUKEN, Nuket Ornek; BALVESEN-ODABASI, Aysun. Physicians' attitudes at the end-of-life: a cross-cultural evaluation. In: Medicine and Law, v. 32, n. 4, December 2013, p. 556. 


\section{CAPÍtUlO VII. APLICABILIDADE, CONSIDERAÇÕES CRÍTICAS E PERSPECTIVAS}

\section{Fundamento e escopo da Resolução 1995/2012 do Conselho Federal de Medicina}

Ao entronizar as diretivas antecipadas de vontade no Brasil, a Resolução 1995 de 2012, do Conselho Federal de Medicina, fundamentou-se de forma explícita na "Convenção para a proteção dos direitos do homem e da dignidade do ser humano face às aplicações da biologia e da medicina", assinada pelos Estados-membros do Conselho da Europa em 4 de abril de 1997 na cidade de Oviedo. Não por acaso, o artigo $9^{\circ}$ da Convenção de Oviedo é praticamente repetido no artigo $2^{\circ}$ da Resolução CFM $1995 / 2012^{338}$. O que, diga-se, foi positivo para o ordenamento ético pátrio na mesma medida em que a Convenção de Oviedo representou uma lufada de ar em um ambiente bioético que se encontrava estagnado na Europa. Isso porque as diretivas antecipadas vão ao encontro dos próprios alicerces principiológicos da Bioética, em especial a autonomia e a não-maleficência.

A Resolução CFM 1995/2012 encontra guarida constitucional no artigo $1^{\circ}$, inciso III, da Carta Magna, que tutela a dignidade da pessoa humana, e também em incisos do artigo $5^{\circ}$ do mesmo diploma, em especial o inciso II, que privilegia a autonomia, e o inciso III, que veda a tortura e o tratamento desumano ou degradante (já que estes são conceitos comparáveis a alguns procedimentos médicos distanásicos) ${ }^{339}$. Em sede civilista, a Resolução tem um terreno sólido no artigo 15 do Código Civil brasileiro, que também respalda a autonomia do paciente, ainda que se deva aqui abstrair o seu enunciado dúbio, que a uma primeira leitura pode suscitar interpretação diversa quando não haja risco de vida. 336 Em suma, pode-se inferir que a Resolução

338. Artigo $9^{\circ}$ da Convenção de Oviedo: "Vontade anteriormente manifestada: a vontade anteriormente manifestada no tocante a uma intervenção médica por um paciente que, no momento da intervenção, não se encontre em condições de expressar a sua vontade, será tomada em conta."

Artigo $2^{\circ}$ da Resolução 1995/2012 do Conselho Federal de Medicina: " Nas decisões sobre cuidados e tratamentos de pacientes que se encontram incapazes de comunicar-se, ou de expressar de maneira livre e independente suas vontades, o médico levará em consideração suas diretivas antecipadas de vontade." 339. Artigo 1”: "A República Federativa do Brasil (...) tem como fundamentos:

III - a dignidade da pessoa humana."

Artigo $5^{\circ}$, inciso II - "ninguém será obrigado a fazer ou deixar de fazer alguma coisa senão em virtude da lei."

Artigo $5^{\circ}$, inciso III - "ninguém será submetido a tortura nem a tratamento desumano ou degradante."

340. Artigo 15: "Ninguém pode ser constrangido a submeter-se, com risco de vida, a tratamento médico ou a intervenção cirúrgica." Quanto à questão da ambiguidade, Sílvio Venosa entende que "Levando em conta que qualquer cirurgia apresenta maior ou menor risco de vida, sempre haverá, em tese, necessidade 
1995/2012 foi bem acolhida pela doutrina civilista e constitucional nacional ${ }^{341}$. A questão penal será analisada mais à frente, no fim deste capítulo.

Por meio desse instrumento normativo, "os médicos tem agora o respaldo ético para evitar o uso da técnica irracional e promover o conforto e a qualidade de vida dos pacientes por meio dos cuidados paliativos" ${ }^{\text {342 }}$, o que a um só tempo assegura a consideração da vontade dos pacientes e a administração dos cuidados especiais que essas condições clínicas merecem. Nessa concepção, desonera os médicos de insistirem em condutas que, por infrutíferas, criavam constrangimentos e até situações dramáticas de consciência, vivenciadas pelos médicos no exercício de sua arte.

Nessa direção, o escopo da Resolução 1995/12 foi revestir de maior harmonia as situações de assistência médica no fim da vida. Isso transparece na própria Exposição de Motivos da Resolução, que embasa a norma legal nos seguintes tópicos: dificuldade de comunicação do paciente em fim de vida; boa receptividade dos médicos às diretivas antecipadas de vontade, segundo pesquisas nacionais e internacionais; boa receptividade dos pacientes; adequação da norma ética com as de ordenamentos de outros países, notadamente Espanha, Itália e Portugal; abertura, prevista na Resolução, para o médico recorrer aos Comitês de Bioética da instituição de saúde em casos de dúvida $\operatorname{procedimental}^{343}$.

Entretanto, ainda que a aceitabilidade das diretivas, em tese, seja boa por parte da comunidade médica, salta aos olhos o pouco conhecimento sobre o instituto por parte de quem deveria possuí-lo, ou seja, justamente os médicos e os advogados. Em recente pesquisa nacional que dissecou o conhecimento destes profissionais e dos graduandos

de autorização do paciente ou de alguém por ele.” Nessa questão, Venosa também remete ao artigo $6^{\circ}$, II, do Código de Defesa do Consumidor, que obriga ao dever de informação, de qualquer tomador de serviços, entendendo o paciente como tal. VENOSA, Sílvio de Salvo. Direito Civil, parte geral, 2008, pp. 179-180. No mesmo sentido, Maria Helena Diniz: "Daí a importância da informação detalhada sobre seu estado de saúde e o tratamento a ser seguido, para que possa dar, ou não, o seu consentimento livre e esclarecido." DINIZ, Maria Helena. Curso de direito civil brasileiro - teoria geral do direito civil, 2008, p. 128. Também Gustavo Monaco: “(...) ele não pode ser constrangido a se submeter ao tratamento ou à cirurgia, mas o médico tem a obrigação de submeter a pessoa a tais tratamentos se ela não estiver em condições de se manifestar, nem houver parentes que autorizem a aplicação da arte médica." MONACO, Gustavo Ferraz de Campos. Direitos da personalidade da pessoa física. In: HIRONAKA, Giselda M. F. N. (orient.). Direito civil - teoria geral, 2008, p. 50.

341. Nesse entendimento: DANTAS, Eduardo. Advance directives and living wills: the role of patient's autonomy in the Brazilian experience. In: Medicine and law, v. 32, n. 4, December 2013, pp. 467 e ss. E também CHAVES, Marianna. Advance directives: the consecration of autonomy and dignity of the human being. In: Medicine and law, v. 32, n. 4, December 2013, pp. 516 e ss.

342. AZEVEDO JÚNIOR, Renato. Diretivas antecipadas de vontade. In: Jornal do CREMESP, editorial, p. 2, edição 296, 09/2012.

343. LIMA, Carlos Vital Tavares Corrêa (rel.). Exposição de motivos da Resolução 1995/12 do Conselho Federal de Medicina, 2012. 
em direito e medicina sobre o "testamento vital", observou-se que somente $29,2 \%$ dos entrevistados sabiam o significado do instituto, ainda que a ortotanásia, intimamente relacionada às diretivas antecipadas, tenha sido considerada aceitável para 87,6\% dos entrevistados $^{344}$.

Esse desconhecimento é mais surpreendente quando se evidencia que as diretivas antecipadas de vontade, cristalizadas no ordenamento ético nacional em 2012, vem sendo construídas desde muito antes, não representando, destarte, um instituto revolucionário e nem tão recente. Além de sua gênese norte-americana na década de 1970 e da tomada de impulso na Europa a partir da última década do século passado, como já foi comentado no capítulo $\mathrm{V}$ desta dissertação, as diretivas foram objeto da Lei Estadual 10241, de 17 de março de 1999, no Estado de São Paulo, que ficou conhecida como Lei Mário Covas ${ }^{345}$. No âmbito ético-normativo, por sua vez, a Resolução 1805 , de 28 de novembro de 2006, já indicava a diretriz que deveria ser seguida, na prática médica, para assegurar o direito do paciente terminal à ortotanásia ${ }^{346}$.

Por certo a publicação das Resoluções supracitadas pelo Conselho Federal de Medicina, tanto em 2006 como em 2012, foram fruto de uma preocupação crescente, ainda que pontual, por parte da classe médica, em face da correta atitude ética a ser tomada frente aos doentes terminais. A título de exemplo, pinçamos a Consulta 18.688, de 2012, ao Conselho Regional de Medicina do Estado de São Paulo, que gerou parecer da lavra do Conselheiro Reynaldo Ayer de Oliveira, fundamentada em preceitos éticos (Resolução CFM 1805/2006), constitucionais e civilistas ${ }^{347}$.

Nessa linha, a jovem Resolução CFM 1995/2012 também se insere à perfeição no espírito do Código de Ética Médica atual, de 2009, servindo como especificação, frente aos cuidados com o paciente terminal, dentro de um códice que privilegia a

344. PICCINI, Cleiton Francisco et. al. Testamento vital na perspectiva de médicos, advogados e estudantes. In: Bioethikos, out/dez 2011, n. 4, pp. 384 e ss.

345. Vide Anexo 5 para o enunciado da íntegra da Lei. Destacam-se, para os fins deste estudo, os seguintes incisos:

“Artigo 2 $2^{\circ}$ : São direitos dos usuários dos serviços de saúde do Estado de São Paulo:

VII - consentir ou recusar, de forma livre, voluntária e esclarecida, com adequada informação, procedimentos diagnósticos ou terapêuticos a serem nele realizados;

XXIII - recusar tratamentos dolorosos ou extraordinários para tentar prolongar a vida;

XXIV - optar pelo local de morte."

346. Vide Anexo 4. Nesse sentido, o artigo $1^{\text {o }}$ da Resolução: "É permitido ao médico limitar ou suspender procedimentos e tratamentos que prolonguem a vida do doente em fase terminal, de enfermidade grave e incurável, respeitada a vontade da pessoa ou de seu representante legal.” A propósito, essa Resolução foi objeto de ação civil pública movida pelo Ministério Público Federal, julgada improcedente.

347. Vide Anexos. 
autonomia. Autonomia essa, importa dizer, não só do paciente, objeto precípuo da expertise médica, mas também a conduta autônoma do próprio médico ${ }^{348}$. O que, perceba-se, torna a novel Resolução CFM 1995/2012 bastante para os fins a que se propõe, qual seja, servir como canal ético-normativo de expressão da vontade do paciente, mesmo do paciente ora incapaz. Sua extrapolação no sentido de transformá-la em lei ordinária, revestindo-a de um viés sancionador e vinculante para o médico, retiraria sua própria essência, eis que desbalancearia a saudável equação de equilíbrio entre a autonomia do médico e a do paciente.

Além disso, por mais que a Resolução CFM 1995/2012 tenha representado um evidente progresso no Brasil em termos de ética médica, não há como alijá-la das críticas e limitações relativas ao instituto das diretivas antecipadas de vontade. Algumas dessas imperfeições, que abordaremos nas linhas finais desse estudo, talvez sejam contornáveis enquanto norma ética, porém podem ser exacerbadas uma vez transformadas em lei.

\section{A forma de comunicação da vontade}

A Resolução CFM 1995/2012 é, à primeira impressão, silente quanto aos requisitos formais de expressão da vontade do paciente, limitando-se, em seu artigo $2^{\circ}$, $\S 4^{\circ}$, a enunciar que "o médico registrará, no prontuário, as diretivas antecipadas de vontade que lhes foram diretamente comunicadas pelo paciente." Note-se, entretanto, o quão revelador do escopo da norma o referido artigo se configura. Primeiro, porque ao dar ao médico a incumbência de registrar a vontade do paciente, privilegia a saudável e necessária relação médico-paciente que deve existir de forma perene, em especial na aferição de vontade do doente como senhor do seu próprio destino. Segundo, porque cristaliza o prontuário médico como documento fundamental no registro da completude de detalhes que revestem o seguimento clínico do paciente, incluindo, talvez de forma inovadora, suas próprias vontades em relação à sua situação clínica. Por fim, o silêncio eloquente do diploma ético quanto a detalhes formais como registro em cartório e

348. Sobre o Código de Ética Médica atual: “A autonomia foi alçada à condição de protagonista das relações, tanto por parte do médico, que nela deve apoiar-se e ser respeitado por isso, quanto e principalmente, por parte do paciente, que tem resguardado o direito de decidir sobre sua saúde, sempre após receber as devidas informações acerca do diagnóstico e tratamento." CAMARGO, Rosmari Aparecida Elias; CAMPOS, Roberto Augusto de Carvalho. A autonomia do médico e do paciente no atual Código de Ética Médica. In: PASCHOAL, Janaína Conceição; SILVEIRA, Renato de Mello Jorge (coords.). Livro homenagem a Miguel Reale Júnior, 2014, p. 638. 
presença de testemunhas carrega um viés não legalista que muito auxilia a aplicabilidade prática das diretivas antecipadas de vontade na assistência à saúde em ambiente clínico hospitalar.

No entanto, não há unanimidade doutrinária neste aspecto. Lançando mão novamente da experiência estrangeira, já que os estudos nacionais sobre o instituto são incipientes, nota-se que a escola europeia, talvez imbuída do espírito da civil law, exige mais requisitos formais para a eficácia das diretivas. Exemplo paradigmático disso é a norma portuguesa, que pressupõe registro em cartório das diretivas antecipadas, como foi referido nesta dissertação ao tratarmos do direito comparado. Ressalte-se, nesse ponto, a quase nascente experiência portuguesa no que tange às diretivas, pelo seu pouco período de tempo de introdução no ordenamento luso, o que faz antever certas dificuldades de utilização das diretivas advindas do excesso de formalismo.

Nos Estados Unidos, por sua vez, não se percebe tal engessamento legal da forma das diretivas. Ainda que haja uma profusão de obras sobre o tema representando verdadeiros tutoriais para a confecção das diretivas na literatura norte-americana, direcionadas tanto ao público leigo quanto aos operadores jurídicos e da saúde ${ }^{349}$ em regra as exigências de forma são tênues. O que, pelo menos em tese, facilita sua utilização à beira do leito. Os autores estadunidenses, cada um a seu modo, e adaptando as diretivas às leis estaduais, tentam oferece-las à maneira de produto, sugerindo por vezes extensos questionários, em que o paciente-cliente escolhe as formas pelas quais deseja ser tratado se confrontado com futuras situações clínicas específicas, nas quais não seja mais capaz de fazer opções ${ }^{350}$. O formato permite uma particularização limitada da maneira pela qual a vontade é expressa.

Há que se ter em mente, no caso brasileiro, que ao enaltecer a oralidade da comunicação da vontade e o registro dessa vontade em prontuário médico, insculpido no artigo $2^{\circ}$, $\S 4^{\circ}$, da Resolução CFM 1995/2012, não há um esgotamento da forma. Certamente não foi essa a mens leges da normativa. Basta pensar, nesse diapasão, nas variadas situações de assistência à saúde, peculiares a um país multifacetado como o Brasil, em que muita vez o agente capaz, potencial signatário de uma diretiva antecipada de vontade para o fim da vida, não se encontra sob a tutela de um médico de confiança ou de uma estrutura de saúde na qual seja acompanhado regularmente. Por

349. A título de exemplo, podem-se mencionar dois livros: COLLINS Jr., Evan R; WEBER, Doron. The complete guide to living wills - how to safeguard your treatment choices, 1991. GODKIN, M. Dianne. Living will, living well - reflections on preparing an advance directive, 2008.

350. COLLINS Jr., Evan; WEBER, Doron, op. cit., pp. 113 e ss. 
conta disso, as diretivas podem, sim, se expressar como documento escrito, nesse caso preferencialmente com o aval de uma ou duas testemunhas, para que se torne eficaz no caso do futuro encadeamento das situações atinentes à diretiva, quais sejam a concomitância de situação clínica que não prescinda de opção terapêutica autônoma e a incapacidade do paciente.

Ainda que em solo norte-americano, como referimos, não se preconize uma restrita fixidez da forma das diretivas, há que se lembrar que a assistência médica nos Estados Unidos tem um forte viés contratual, afastando-se cabalmente dos modelos mais personalistas, usuais em vários países da Europa e também no Brasil. O reflexo disso é que as diretivas, observadas como contrato, comportam confortavelmente a utilização de testemunhas no momento em que são firmadas, o que é particularmente importante no caso de pacientes idosos, em que pode haver, em tese, mais dúvidas sobre a capacidade do signatário da diretiva. Em geral se sugere a presença de duas testemunhas ${ }^{351}$.

Ressalte-se que a presença de testemunhas é objeto de limitação normativa no sentido de quem pode se prestar a essa função. A doutrina norte-americana é concorde no sentido de que as testemunhas sejam adultos capazes, que não sejam responsáveis pela administração direta do tratamento, e que não haja grau de parentesco sanguíneo ou conjugal com o paciente. Também não pode haver relações comerciais, processuais ou empregatícias do signatário com a testemunha, principalmente com a primeira ou principal $^{352}$.

Nesse sentido, a opção por testemunhas teria por fulcro revestir as diretivas de maior confiabilidade, dada a importância das decisões que podem fluir delas em uma situação terapêutica delicada. Confiabilidade essa direcionada tanto à equipe de saúde, ao prestar atendimento a um paciente do qual não conhece o histórico e nem os valores pessoais, mas também um sentido pessoal de conforto do próprio paciente, ao se certificar que suas opções serão recepcionadas pela equipe que futuramente o tratará.

351. “(...) In long-term facilities, elders usually need two witnesses for their advance directives, one being a representative from the ombudsman's office who serves as the resident elder's advocate. When the resident wishes to make changes to an existing advance directive an ombudsman representative must be present." WHITE, Barbara; TRUAX, Deborah. The nurse practitioner in long-term care: guidelines for clinical practice, 2007, p. 54.

352. "Two competent adult witnesses must sign below, acknowledging the signature of the declarant. The witness designated as Witness 1 may not be a person designated to make a treatment decision for the patient and may not be related to the patient by blood or marriage. This witness may not be entitled to any part of the estate and may not have a claim against the estate of the patient. This witness may not be the attending physician or an employee of the attending physician. If this witness is an employee of a health 
Com essa mesma finalidade de conferir segurança às opções de vontade expressa nas diretivas, e nesse sentido quase inerente ao próprio instituto, configura-se a atribuição do representante para cuidados de saúde no fim da vida, objeto do próximo tópico deste estudo.

\section{O representante para cuidados de saúde no fim da vida}

Boa parte da doutrina dos Estados Unidos, incluindo a American Medical Association, faz uma clara distinção entre o procurador para cuidados de saúde (tradução usual para durable power of attorney, que em alguns estados norteamericanos se denomina medical power of attorney, ou ainda health care proxy) e o testamento vital (living will), sendo ambos espécies do gênero das diretivas antecipadas de vontade (advance directives). Ainda assim, os institutos se complementam, sendo que, para alguns, o procurador acaba por ter uma abrangência maior do que o living will, pelo fato de um documento previamente escrito, em geral, não ter a capacidade de abarcar a enorme e complexa gama de situações clínicas possíveis quando o paciente tiver se tornado incapaz. Destarte, o procurador para cuidados de saúde teria o condão de suprir essa lacuna, assumindo decisões no interesse de seu representado, nas eventualidades médicas em que este não puder mais decidir ${ }^{353}$.

A norma ética brasileira encampou uma visão diferente da norte-americana, ao não utilizar o termo "testamento vital", preferindo "diretivas antecipadas de vontade", sobre o que já discorremos em linhas anteriores, e ao inserir o "representante" como complementação das diretivas, consoante o artigo $2^{\circ}$, $\S 2^{\circ}$, da Resolução CFM 1995/2012. Ou seja, aqui também houve clara inspiração europeia, por parte do Conselho Federal de Medicina, ao acolher o termo "representante" expresso no Convenio para la proteción de los derechos humanos y la dignidade del ser humano con respecto a las aplicaciones de la biología y la medicina (Convenção de Oviedo), de 1999, em seu artigo $6^{\circ}$, inciso $4^{\circ}$, Capítulo II (vide Anexo 2). Por ter sido o termo usado

care facility in which the patient is being cared for, this witness may not be involved in providing direct patient care to the patient. This witness may not be an officer, director, partner, or business office employee of a health care facility in which the patient is being cared for or of any parent organization of the health care facility. EDSEL, Ernest. The complete legal form book of living wills, 2009, p. 11.

353. "The AMA suggests a medical directive as a substitute for the living will and suggests further that these be made available in physicians' offices and hospitals and included as part of the medical record. Assessing the relative merits of the living will and durable power of attorney for health care, the AMA finds that the durable power of attorney can cover a broader range of illnesses than the living will (...)" FLIGHT, Myrtle. Law, liability \& ethics for medical office professionals, 2011, p. 288. 
pelo legislador nacional, o vocábulo "representante" será referido nesse estudo quando nos reportarmos ao ordenamento ético nacional, reservando "procurador" para a correspondente função na norma estadunidense. Ainda assim, o tipo de atividade da pessoa que assume esse encargo não apresenta diferenças práticas ao compararmos os dois países, qual seja a atribuição de assumir decisões concernentes à saúde do representado incapaz, em face de situações específicas que não foram açambarcadas nas diretivas. Note-se, porém, que a figura do representante, na Resolução brasileira, é inerente a esta, portanto as limitações e imperfeições da representação se estendem e se refletem nas próprias diretivas antecipadas de vontade.

Justamente nesse aspecto é que se pode configurar uma primeira crítica à convivência dos dois institutos, pois não é difícil imaginar uma situação em que haja conflito entre o que foi expresso nas diretivas e a decisão do representante frente a um fato médico. Problema exacerbado, por certo, pela ausência do limite da representação pela incapacidade do agente (daí o termo durable power of attorney na língua inglesa), ao contrário do que ocorre em uma procuração advocatícia habitual, que encontra seus liames no período em que o representado é capaz ${ }^{354}$.

Para mitigar esse risco, a doutrina sugere alguns filtros, começando pelos próprios critérios de escolha do representante. Suas qualificações devem incluir: "habilidade de fazer julgamentos razoáveis (competência); conhecimento e informação adequados; estabilidade emocional; comprometimento com os interesses da pessoa incompetente, livre de conflitos de interesse e livre da influência daqueles que possam não agir no sentido do melhor interesse do paciente" ${ }^{, 355}$. Além disso, o representante deve se apartar do atributo da neutralidade, agindo, pelo contrário, com parcialidade na defesa dos interesses do representado, à maneira de um advogado ${ }^{356}$.

Nesse diapasão, além dos atributos pessoais e de conduta do representante, outro filtro de otimização de sua atividade deve ser emanado do seu modus operandi quando requerido. Aqui podem se decantar três vertentes ${ }^{357}$ :

354. HALES, Robert E.; YUDOFSKY, Stuart C.; GABBARD, Glen O. (ed.) The American Psychiatric Publishing textbook of psychiatry, 2008, p. 1564. Também nesse sentido: "A durable power of attorney remains in effect even if the creator becomes incompetent. This is not normally the case with the general or special power of attorney. Incompetence of the creator invalidates those two powers of attorney unless certain language is included to make a power of attorney's effect durable." GALLO, Nancy R. Elder law, 2009, p. 67.

355. BEAUCHAMP, Tom L.; CHILDRESS, James F. Principles of biomedical ethics, 2013, p. 190. (tradução livre do autor)

356. Idem.

357. Idem, pp. 226 e ss. 
a) "padrão de substituição do julgamento": neste método de agir do representante, tentase atuar partindo da premissa que as decisões sobre as condutas médicas pertencem ao paciente incompetente, ou que perdeu sua autonomia. Para isso, cabe ao representante fazer o trabalho mental de se colocar no lugar do representado, procurando agir como esse agiria em face daquela situação específica, se fosse competente.

b) "padrão de autonomia pura": aqui a atuação do representante deve respeitar a autonomia pregressa do paciente, ou seja, da época em que este era competente, levando em consideração os valores de vida anteriores à patologia ou acidente que o tornou incompetente. Por óbvio esse padrão só é aplicável a representados que foram capazes no passado, o que limita sua aplicabilidade em certos casos.

c) "padrão do melhor interesse": nessa linha de decisão, não há dependência da autonomia ou capacidade prévia do representado, porque o representante age, ele mesmo com autonomia no sentido do melhor interesse do paciente, tendo como foco sua qualidade de vida.

Ainda que não haja uma hierarquia formal entre os padrões de atuação acima, vale ressaltar que o padrão do melhor interesse do paciente em geral tem maior força, podendo mesmo suplantar decisões expressas em diretivas antecipadas no caso de conflito $^{358}$. Nesse sentido, ele acaba sendo corolário de um dos pilares da Bioética, o princípio da beneficência.

No entanto, nenhum dos filtros acima citados imuniza contra a possibilidade de conflitos éticos advindos de discrepâncias entre a expressão prévia de vontade do signatário de uma diretiva, agora incapaz, e a decisão do representante, o que desvela algumas imperfeições existentes na própria essência das diretivas antecipadas de vontade.

\section{Renovação, retificação e revogação das diretivas}

Mesmo que as diretivas antecipadas de vontade para o fim da vida não tenham prazo de validade, convém renová-las periodicamente. Isso tem como fundamentação o

358. “(...) The best interests standard protects an incompetent person's welfare interests by requiring surrogates to assess the risks and probable benefits of various treatments and alternatives to treatment. It is therefore inescapably a quality-of-life criterion. The best interests standard can in some circumstances validly override advance directives executed by formerly autonomous patients, as well as consents or refusals by minors and by other incompetent patients." BEAUCHAMP, Tom L.; CHILDRESS, James F., op. cit., p. 228. (grifo nosso) 
desiderato de convencimento que as diretivas antecipadas possuem, tanto para a equipe de saúde que assistirá o paciente, quanto para qualquer tipo de litígio, e. $g$. um conflito de opiniões entre os familiares do doente. Admitindo que as diretivas antecipadas de vontade são utilizadas, em grande parte, em pacientes idosos, é importante explicitar que em época não muito remota o signatário se encontrava comprovadamente capaz e senhor de suas opções ${ }^{359}$. Além disso, o constante surgimento de novas tecnologias médicas, com reflexos nas condutas terapêuticas de manutenção da vida, pede a manifestação de quem poderá ser objeto dessas intervenções ${ }^{360}$. Nesse sentido, quanto mais próxima no tempo a expressão de vontade da diretiva, em relação ao evento mórbido de cuja concretização deflui o emprego do documento, melhor.

O período indicado para essa renovação não é consensual para os doutrinadores, variando para cada país. Na França, por exemplo, as diretivas costumam ser reafirmadas a cada três anos ${ }^{361}$, enquanto nos Estados Unidos esse período habitualmente é de cinco $\operatorname{anos}^{362}$.

A retificação das diretivas segue a mesma essência da renovação, caminhando em sentido inverso ou complementando o documento. Assim, o agente capaz que havia anteriormente firmado uma diretiva pode se convencer que deseja, ou não, ser submetido a determinado procedimento que surgiu na arte médica atual, ou do qual foi recentemente informado pelo médico que o assiste, e por conta disso alterar a diretiva, explicitando sua decisão. Além disso, o signatário pode ter experimentado uma mudança em seus valores pessoais, com reflexos em seus conceitos em face do processo da morte, o que pode ser decorrência, por exemplo, da aderência ou do abandono de algum credo religioso.

A retificação, uma vez que as diretivas representam negócio jurídico unilateral, à maneira de um testamento, por certo podem ser feitas a qualquer tempo, desde que o agente se encontre no exercício de sua capacidade. Essa regra vale também para a sua revogação ${ }^{363}$.

359. Isso é particularmente importante no caso de pacientes com predisposição a doenças mentais degenerativas, como a moléstia de Alzheimer, cuja prevalência é cada vez maior devido ao fenômeno global do aumento da expectativa de vida. Nesse sentido: PURTILO, Ruth B.; HAVE, Henk A. M. J. (ed.) Ethical foundations of palliative care for Alzheimer disease, 2010, p. 252.

360. KING, Nancy. Making sense of advance directives, 1996, pp. 39 e ss.

361. NUNES, Rui; MELO, Helena Pereira de. Testamento vital, 2011, p. 129.

362. KILBURN, Julian. Answer plans for the Medical Research Council of General Practitioners, 2005, p. 126.

363. “(O testamento...) É essencialmente revogável (Código Civil artigo 1969), sendo inválida a cláusula que proíbe sua revogação. A revogabilidade é da essência do testamento, não estando o testador obrigado 


\section{As diretivas aplicadas aos menores de idade}

Os menores de idade são considerados, na norma civil nacional, absolutamente ou relativamente incapazes, sendo os primeiros os menores de dezesseis anos, e os últimos os maiores de dezesseis e menores de 18 anos $^{364}$. Além disso, não se deve perder do horizonte legal o que foi discutido em relação à interação entre autonomia e capacidade no item 1.4 do Capítulo IV desta dissertação.

Entretanto, começa a haver alguma discussão, nos países que acolheram as diretivas antecipadas de vontade, em relação à possibilidade de menores de idade produzirem uma diretiva. Nos Estados Unidos esta questão vem à baila desde fins da década de 1980, e a doutrina parece caminhar no sentido de que o menor seja ouvido nos casos que concernem a condutas relativas à sua própria saúde ${ }^{365}$.

O que importa, na possibilidade de um menor expressar sua vontade no que tange a qualquer tipo de terapêutica médica, sendo que as diretivas, enquanto autorização ou vedação a procedimentos de saúde, não fogem a essa regra, é a capacidade de entendimento. Assim, ainda que um menor seja civilmente incapaz, devendo ser assistido por um responsável, no caso de sua possibilidade de discernimento ser suficiente para que se aperceba de seu quadro clínico atual e de seu prognóstico, nada impede que seja ouvido. Dito de outra forma, o rótulo da incapacidade, per se, não deve alijar o menor de sua voz quanto ao porvir de seu próprio tratamento $^{366}$.

Mesmo assim, as situações que envolvem as decisões de fim da vida atinentes aos menores são invariavelmente mais delicadas, não só por envolverem um fardo

a declinar os motivos de sua ação. Pode o testador, pois, usar do direito de revogá-lo, total ou parcialmente, quantas vezes quiser (artigo 1858 do Código Civil)." GONÇALVES, Carlos Roberto. Direito das sucessões, 2011, p. 232.

364. Segundo o Código Civil, respectivamente artigos $3^{\circ}$, I, e artigo $4^{\circ}$, I.

365. "A living will and durable power of attorney for healthcare have no legal validity unless the person who completes them is more than eighteen years of age. However, anything concerning his or her medical care that a minor cares about enough to put into writing may be influencial in cases where difficult decisions need to be made." COLLINS, Evan R.; WEBER, Doron. The complete guide to living wills how to safeguard your treatment choices, 1991, p. 38.

366. Nessa linha: "Often competency is considered a legal term as in "now that she is 18 years old she is legally competent to make her own decisions." The American Society of Anesthesiologists (ASA) in their Manual on Professional Liability define competence as "a patient's legal authority to make decisions" and capacity as "a determination (made by medical professionals) that patient has the ability to make a specific decision at a specific time". (...) The important consideration is that whatever label is used in obtaining consent, it applies solely to the patient's mental ability at that time to give or refuse consent to that particular procedure." SURESH, Maya. Shnider and Levinson's anesthesia for obstetrics, 2013, p. 677. 
emocional maior, mas porque podem contrapor valores parentais, que nem sempre se harmonizam com a busca pela melhor qualidade de vida da criança. Em regra, o critério de decisão acaba sendo o do "padrão do melhor interesse" (vide item 3 deste Capítulo), cuja aferição, porém, também é complexa ${ }^{367}$.

\section{A conduta na ausência das diretivas antecipadas de vontade}

Essa é a situação mais comum na atualidade, já que ainda são raras as pessoas que confeccionaram uma diretiva antecipada de vontade para o fim da vida. Além disso, alguns pacientes, felizmente poucos hoje em dia, até se recusam a ser informados sobre sua patologia, o que, mesmo de forma enviesada, não deixa de ser o exercício de sua autonomia $^{368}$. Longe de retornar ao antigo sistema paternalista, hoje tornado obsoleto e inadequado pelos novos patamares da relação médico-paciente, já abordados neste estudo, a falta de registro da vontade do paciente, em uma situação em que ora se encontre incapaz e submetido a procedimentos de manutenção da vida, requer determinadas condutas por parte das equipes de saúde. Condutas que, acertadamente, foram previstas pela Resolução CFM 1995/2012, em seu artigo $2^{\circ}$, § $5^{\text {o369 }}$.

Vê-se que a finalidade do referido parágrafo foi, ao formular uma sistematização em relação aos órgãos aos quais se deve recorrer, criar uma regra facilitadora para os médicos que lidam com casos, por si só, desafiadores. Ou seja, ao prescrever uma hierarquização de pessoas ou instituições a quem as equipes de saúde devem recorrer, procurou desonera-las da responsabilidade de arcar com decisões éticas cruciais.

367. "Determinar o curso de uma ação que vá ao encontro dos melhores interesses da criança nem sempre é fácil. Os pais tem o direito fundamental de direcionar a criação de seus filhos no sentido de que ela seja compatível com seus valores, e este direito é em geral extensível à condução das decisões médicas. Ao determinar o curso de uma ação que privilegie o melhor interesse da criança, os benefícios esperados do tratamento devem ser sopesados em relação ao direito de os pais controlarem os cuidados médicos da criança segundo suas crenças e valores." JONSEN, Albert R.; SIEGLER, Mark; WINSLADE, William J. Clinical ethics - a practical approach to ethical decisions in clinical medicine, 2010, p. 159. (tradução livre do autor)

368. "Persons have a right to information about themselves. Similarly, they have the right to refuse information or ask the physician not to inform them." JONSEN, Albert R.; SIEGLER, Mark; WINSLADE, William J., op. cit., p. 63.

369. Art. $2^{\circ}, \S 5^{\circ}$ : "Não sendo conhecidas as diretivas antecipadas de vontade do paciente, nem havendo representante designado, familiares disponíveis ou falta de consenso entre estes, o médico recorrerá ao Comitê de Bioética da instituição, caso exista, ou, na falta deste, à Comissão de Ética Médica do hospital ou ao Conselho Regional e Federal de Medicina para fundamentar sua decisão sobre conflitos éticos, quando entender esta medida necessária e conveniente." 
Não há, decerto, uma imunização completa contra possíveis problemas. Os Comitês de Bioética, por exemplo, ainda não foram consolidados em muitas instituições de saúde. Além disso, uma vez que pertencem às próprias instituições, podem ser sujeitos a alegações éticas de conflito de interesses ${ }^{370}$, cuja solução seria a consulta a um comitê independente, o que é de difícil aplicabilidade prática na realidade nacional. As Comissões de Ética Médica, por sua vez, podem ser de difícil mobilização no caso de necessidade de decisão rápida.

A saída mais viável, nesses últimos casos, seria o denominado "consentimento subentendido", formatado para situações emergenciais com risco de vida em que não há acesso ao consentimento, ou em que o consentimento não existe (por exemplo, uma decisão sobre fazer ou não reanimação cardiorrespiratória em um paciente terminal). Nessa linha de conduta, a equipe de saúde assume uma espécie de presunção de consentimento, embasada no princípio bioético da beneficência ${ }^{371}$.

De qualquer forma, os possíveis dilemas consequentes à ausência das diretivas antecipadas de vontade para o fim da vida reforçam o acerto de sua finalidade ética. Melhor com as diretivas do que sem elas.

\section{A Resolução CFM 1995/2012 e o Código Penal}

Ao discorrermos, nos capítulos iniciais desta dissertação, sobre a eutanásia e a ortotanásia, chamando a atenção para os fundamentos e princípios a elas subjacentes, o objetivo não foi o de exaurir o assunto. Vários pesquisadores já procuraram fazê-lo, com maior ou menor propriedade. Ocorre que a pesquisa das diretivas antecipadas de vontade para o fim da vida, objeto desse estudo, deve necessariamente perpassar por uma abordagem daqueles institutos, devido à íntima relação das diretivas com eles.

De fato, não há como enfocar as diretivas antecipadas de forma estanque, como se fossem uma norma ética que ambicionasse, no máximo, uma promoção a norma

370. “(...) ethics commitees are hospital entities, and as such, open to allegations of conflict of interest. It is important that hospitals formulate a policy that would provide for a decision-making process in which conflict is reduced, for example, by having an outside consultant or by submitting the case to another ethics committee.” JONSEN, Albert R.; SIEGLER, Mark; WINSLADE, William J., op. cit., p. 91.

371. Sobre essa teoria, discorrem JONSEN et. al.: “(...) This is sometimes called implied consent. The patient is not, of course, giving consent; the physician is presuming that the patient would consent, if they could. From the ethical point of view, the principle of beneficence, which prescribes that a person has a duty to assist someone in serious need of help, is the ethical justification for emergency treatment of the incapacitated person." Idem, p. 90. 
jurídica. Como foi explicitado no início deste capítulo, as diretivas antecipadas de vontade já carregam uma essência de harmonização sistêmica com o ordenamento constitucional, principalmente se lançarmos a elas um olhar valorativo e principiológico.

No entanto, essa harmonia, infelizmente, não alcança a norma penal. Por mais que se possa argumentar no sentido da descriminalização da ortotanásia, lançando luz sobre fundamentos doutrinários como a exclusão da tipicidade, como o fizemos em linhas anteriores, fato é que a eutanásia e a ortotanásia são criminalizadas pelo atual Código Penal. Essa penalização nasce do silêncio do Código Penal especificamente em relação a esses institutos. Assim, as várias modalidades de eutanásia, incluindo a ortotanásia, se assim entendida, em tese são subsumíveis aos artigos 121 (homicídio) e 122 (induzimento, instigação ou auxílio ao suicídio), de acordo com o caso. Da discricionariedade do juiz, no caso do artigo 121, pode ser aplicado caso de diminuição de pena, o que parece mais palatável. Porém pode haver, no sentido inverso, uma qualificadora, se o julgador entender que não havia chance de defesa do ofendido ${ }^{372}$.

Também não parece haver fundamento em fazer uma diferenciação moral ou jurídica cabal entre a ortotanásia e a eutanásia, ainda que em tese a primeira pudesse carregar, a priori, um menor desvalor da conduta. Os bioeticistas Tom Beauchamp e James Childress apontam que a linha divisória moral entre o "matar" e o "deixar morrer" não é clara, sendo ambos aceitáveis na medicina desde que haja "uma das duas condições: (1) uma tecnologia médica que seja inútil no sentido estrito da futilidade terapêutica (...), ou (2) os pacientes ou seus representantes tenham validamente recusado o emprego de tecnologia médica”373. Assim, a diferenciação entre ortotanásia e eutanásia passiva, por exemplo, seria muito menos importante do que a justificação que subjaz a conduta; essa, sim, deve ser sólida e bem delineada ${ }^{374}$. Esse enfoque,

372. GUIMARÃES, Marcello Ovídio Lopes. Eutanásia: novas considerações penais, 2011, p. 229.

373. BEAUCHAMP, Tom L.; CHILDRESS, James F. Principles of biomedical ethics, 2013, pp. 175-176. (tradução livre do autor)

374. "In short, the labels "killing" and "letting die", even when correctly applied, do not determine that one form of action is better or worse, or more or less justified, than the other. Some particular instance of killing, such as a brutal murder, may be worse than some particular instance of allowing to die, such as forgoing treatment for a PVS patient; but some particular instance of letting die, such as not resuscitating a patient whom physicians could potentially save, also may be worse than some particular instance of killing, such as mercy killing at the patient's request. Nothing about either killing or allowing to die entails judgements about wrongness or rightness. Rightness and wrongness depend on the merit of the justification underlying the action, not on whether it is an instance of killing or letting die. Neither killing or letting die is per se wrong. In this regard, we can distinguish them from murder, which is per se wrong." Idem, p. 176. 
ainda que seja passível de críticas por parte da doutrina mais conservadora, acabaria por carrear uma visão mais condizente com valores sociais em constante mutação, valores dos quais o direito penal deve ser um reflexo ${ }^{375}$. Além disso, concorreria para uma maior facilidade de pacificação na abordagem de casos dúbios em termos de definição, como as ordens de não-ressuscitação, em que muitas vezes há um limbo entre o que se pode classificar como ortotanásia, e o que se pode definir como eutanásia passiva. Nesse caso, agravado pelo fato de essas situações poderem ser emergenciais, não comportando consultas e análises bioéticas aprofundadas, eis que os médicos em geral não são bioeticistas, assim como os juízes não o são. Frise-se, nesse diapasão, que o afluxo das novas tecnologias médicas traz em seu bojo a tendência de amalgamar aqueles subtipos de eutanásia que foram explanados nos capítulos iniciais dessa dissertação, o que se torna um complicador adicional em tema já tão complexo.

Nesse sentido, chama atenção a evidente antinomia de uma norma ética que preconiza, por parte dos médicos, condutas promotoras de alívio em situações de sofrimento dos pacientes, contrapondo-se a um ordenamento penal que continua criminalizando esses mesmos atos. O legislador, com certeza, andaria melhor se fosse claro na retirada da eutanásia em geral, e da ortotanásia em particular, do rol dos delitos. A jurisprudência, por sua vez, é silente sobre o tema, ainda que já comecem a haver algumas manifestações arejadas, ainda que isoladas, de órgãos do Judiciário ${ }^{376}$.

A importância de tocar nesse ponto, ressalte-se, não visa apenas à pureza sistêmica de um ordenamento que deveria se aperfeiçoar, ou seja, não tem meramente um fim doutrinário. A despenalização da ortotanásia, e também da eutanásia, dotaria de firme substrato legal uma norma ética, insculpida na Resolução CFM 1995/2012, que é direcionada às equipes de saúde, e, em última análise, ao conforto do próprio paciente. A forma como a norma penal agora é posta acaba por criar um constante sentimento de ilicitude no espírito do médico que quer fazer o melhor por seu paciente e respeitar sua

375. “(...) o que se verifica é que nem todos os delitos correspondem a um "mínimo ético” compartilhado pela sociedade, especialmente quando se considera que esse mínimo tende a ser cada vez mais reduzido conforme a sociedade se torna mais heterogênea e plural." GOMES, Mariângela Gama de Magalhães. $O$ valor normativo da jurisprudência penal, 2007, p. 195.

376. Uma destas raras manifestações é a de Evangelina Duarte, Desembargadora do Tribunal de Justiça de Minas Gerais: "Avança-se, porém, para se admitir a eutanásia, quando previamente admitida pelo paciente, e nas hipóteses em que o tratamento se destina tão somente à manutenção de vida vegetativa, ligada a equipamentos que permitem vida artificial." DUARTE, Evangelina Castilho. O direito de morrer a propósito da Resolução n ${ }^{\circ}$ 1995/2012 do Conselho Federal de Medicina. In: Jurisprudência mineira órgão oficial do Tribunal de Justiça do Estado de Minas Gerais, a. 63, v. 202, jul./set. 2012, p. 25. 
autonomia, seguindo normativa de cunho ético. Dito de outra forma, o fomento à maior utilização e à melhor eficácia das diretivas antecipadas de vontade para o fim da vida deve partir não da vinculação cega do médico à vontade que o paciente expressou nas diretivas $^{377}$, mas sim da retirada da potencial restrição penal que se debruça sobre o médico como constante ameaça.

Além de representar um refinamento no emprego das diretivas, a modificação da diretriz legal em face da eutanásia e ortotanásia suscitaria, em sede doutrinária, um passo além na saudável mitigação do que se chama de paternalismo penal, fenômeno que foi bem estudado por Gerald Dworkin ${ }^{378}$, e que já comentamos anteriormente.

\section{Das imperfeições e limitações do modelo normativo}

Há quem diga, de forma um tanto cáustica, que as diretivas antecipadas de vontade "prometem muito, mas entregam pouco"379. A crítica recorrente às diretivas, em especial nos Estados Unidos, onde o instituto surgiu e vige há cerca de trinta anos, reside justamente no problema da falta de eficácia.

Como relatamos em linhas anteriores, as diretivas tomaram impulso em solo norte-americano a partir do clamor popular advindo dos casos de Karen Ann Quinlan, na década de 1970, e de Nancy Cruzan, no decênio seguinte. Logo após esta última, em 1991, foi promulgado o "Patient Self Determination Act" (PSDA), obrigando as instituições de saúde que recebessem fundos do sistema Medicare a questionar os pacientes e seus familiares se aqueles possuíam uma diretiva antecipada de vontade, e, caso não possuíssem, se tinham interesse em fazê-lo. Parecia um bom método de fomento, mas os resultados, ao longo do tempo, acabaram por se revelar frustrantes.

Poucos norte-americanos se dispõem a formular uma diretiva antecipada, apesar

377. Note-se que a cogência da conduta do médico não é o espírito da norma, como se depreende do caput do artigo $2^{\circ}$ da Resolução CFM 1995/2012: "Nas decisões sobre cuidados e tratamentos de pacientes que se encontram incapazes de comunicar-se, ou de expressar de maneira livre e independente suas vontades, o médico levará em consideração suas diretivas antecipadas de vontade." Também o $\S 3^{\circ}$ do mesmo artigo, que expressa: "As diretivas antecipadas do paciente prevalecerão sobre qualquer outro parecer não médico, inclusive sobre os desejos dos familiares." (grifos nossos)

378. DWORKIN, Gerald. Paternalismo. In: Revista justiça e sistema criminal: modernas tendências do sistema criminal, 2012, pp. 7 e ss.

379. WILKINSON, Anne M. Advance directives and Advance Care Planning: the US experience. In: THOMAS, Keri; LOBO, Ben (ed.). Advance Care Planning in end of life care, 2011, p. 190. (tradução livre do autor) 
do contínuo estímulo propagandístico para que o façam. Estima-se que, atualmente, apenas cerca de $20 \%$ dos norte-americanos tenham feito uma diretiva ${ }^{380}$.

Avolumam-se teses tentando explicar porque as pessoas não aderiram às diretivas, nos países onde já entraram em vigor há muito tempo. Algumas dessas explicações podem ser encontradas no sentimento do público-alvo em face de um assunto do qual "não querem falar, menos ainda registrar por escrito"381. Haveria como que uma rejeição natural à perspectiva da morte e do processo que gira em torno dela, agravada por alguns fatores: falta de informação sobre assuntos médicos; dificuldade de vislumbrar condutas futuras a respeito de situações complexas e abstratas; temor de rejeição a posteriori em face de vontades assumidas no presente ${ }^{382}$.

Há um percepção geral de que a expressão de vontade registrada nas diretivas nem sempre será concretizada nos futuros tratamentos. Talvez um dos motivos para isso seja uma falibilidade de concatenar essa expressão com as reais situações clínicas nas quais fossem necessárias, às vezes porque as diretivas são genéricas demais, ou então por conta da sua confecção não ter sido acompanhada por um médico ${ }^{383}$.

Nessa linha, além da necessária consultoria técnica, a adequada feitura de uma diretiva envolve um verdadeiro processo educativo do paciente, no sentido de colmatar as várias possibilidades de agravos de saúde e suas possibilidades terapêuticas com os desejos da pessoa em relação a esses tratamentos. Na prática, a necessidade dessa educação acaba sendo um obstáculo, partindo da própria disponibilidade das equipes de saúde em oferecer esse tipo de informação ${ }^{384}$. Até porque parece consensual entre médicos e pacientes que cabe ao médico iniciar a discussão sobre as diretivas, preferencialmente no próprio consultório, antes mesmo de uma internação ${ }^{385}$. Porém a necessidade do apoio médico adequado em todos os passos que envolvem as diretivas

380. GONZÁLEZ, Miguel Ángel Sánchez. Testamentos vitais e diretivas antecipadas. In: RIBEIRO, Diaulas Costa (org.). A relação medico-paciente: velhas barreiras, novas fronteiras, 2010, p. 148. 381. Idem.

382. Idem, pp. 149-150.

383. WILKINSON, Anne M., op. cit., p. 194.

384. Idem: "Simple educational efforts at clinicians and consumers to increase Advance Directives completion rates have not been effective. More comprehensive educational interventions, such as multifaceted, longitudinal interactive patient-centred programmes (e.g. person-to-person counseling or education, training in $\mathrm{AD}$ form completion, printed educational materials, and multiple direct interactions between patients and clinicians over many visits) have been found to moderately increase completion rates."

385. GUINN, Keydron Kordell. Physicians' perspectives on discussing patient advance directives, 2008, p. 23. 
antecipadas enseja um viés social importante, que redunda no fato de que a grande clientela das diretivas é representada pela população branca, idosa, de alto nível sócioeconômico e que já vivencia algum agravo de saúde importante ${ }^{386}$.

A necessidade de que as diretivas sejam feitas por um agente capaz, para que sejam válidas, ainda que não possa ser considerada uma imperfeição do instituto, mas sim uma garantia, pode reverter em questionamentos, mormente nas enfermidades cujo cerne seja a incapacidade mental progressiva, como é o caso das demências ${ }^{387}$.

Algumas distorções na feitura das diretivas antecipadas de vontade para o fim da vida tem raízes nas atitudes médicas perante o documento. Muitos profissionais não tem tempo de orientar sua clientela na feitura das diretivas, ou mesmo não tem a expertise necessária para fazê-lo. Alguns médicos encaram as diretivas como fundamental apenas para pacientes que já estejam "doentes o suficiente", retirando das diretivas a sua própria razão de existir ${ }^{388}$.

Também não se deve esquecer dos potenciais problemas quanto à concordância dos familiares em relação às diretivas, o que pode ser fonte de litígios ${ }^{389}$. As atitudes dos representantes ou procuradores, por sua vez, como já foi comentado nesse estudo, são possíveis geradoras de tensão quanto às decisões terapêuticas.

Ainda que, como dissemos antes, a forma das diretivas não é engessada e admite variações, talvez o maior defeito das diretivas antecipadas de vontade, na questão da eficácia, seja o foco excessivo no preenchimento de formulários ${ }^{390}$. De fato, os críticos do instituto ético-legal alegam que ao se prender a detalhes de forma as diretivas perderam muito de sua essência, que deveria se voltar aos valores do paciente em relação ao processo da morte. Isso resultou em uma reformulação das normas como um todo, culminando nas alternativas mais modernas ao instituto, que serão tratadas no próximo item desta pesquisa.

386. WILKINSON, Anne M., op. cit., p. 194.

387. MEISEL, Alan. Legal aspects of end-of-life decision making. In: STEINBERG, Maurice D.; YOUNGNER, Stuart J. End-of-life decisions: a psychosocial perspective, 1998, pp. 241-242.

388. “(...) Physician barriers to advance directives discussions: 1) Lack of time; 2) Lack of necessary communication skills and expertise; 3) Perceived low health literacy of patients; 4) Perception that their patients are not "sick enough"." WILKINSON, Anne M., op. cit., p. 195.

389. Nesse quesito, entretanto, a Resolução CFM 1995/2012 corretamente sobrepõe as decisões elencadas nas diretivas sobre os desejos dos familiares, em seu artigo $2^{\circ}, \S 3^{\circ}$.

390. WILKINSON, Anne M., idem. 


\section{Um passo além das diretivas: planejamento antecipado de tratamentos}

A partir da segunda metade da década de 1990, ficou evidente, nos Estados Unidos, a percepção de que as diretivas antecipadas de vontade tinham várias limitações para sua aplicabilidade ${ }^{391}$. Por conta disso, emergiu a necessidade de uma reformulação do instituto, tendo como fulcro resgatar o viés mais valorativo, em detrimento do normativo, das diretivas.

O resultado desse esforço reformador foi o que se convencionou denominar "advance care planning", que em tradução livre pode ser chamado de planejamento antecipado de tratamentos. Ao deslindar os valores do paciente em relação a tudo que cerca as possíveis terapêuticas aplicáveis ao processo da morte, o planejamento antecipado de tratamentos carrega a meta ambiciosa de suavizar esses momentos, tanto para o próprio paciente quanto para sua família. Disso redunda, por óbvio, uma otimização dos atos médicos, facilitando a atuação das equipes de saúde.

Na mesma trilha, como a tomada de valores de vida dos pacientes requer uma "logística" mais detalhada e prolongada, apartada do mero preenchimento de um formulário, acaba por envolver necessariamente os familiares e os representantes do paciente. Disso resulta uma saudável diminuição do risco de futuros conflitos, o que pode ser promissor, especialmente como política pública de saúde ${ }^{392}$.

Nesse sentido, o planejamento antecipado de saúde reconhece que as vontades relacionadas ao fim da vida das pessoas recebem os influxos de valores individuais, como religião, cultura, escolaridade, objetivos de vida, relacionamento familiar e tantos outros. Portanto, não podem ser pautadas por simples concepções formalistas, sejam elas médicas ou jurídicas, sob o risco de incorrerem em graves distorções.

O planejamento antecipado de saúde exsurge de um contexto contemporâneo que envolve um tripé: longevidade crescente, tecnologia médica avançada e um foco crescente nos direitos do consumidor. Tudo temperado por um ambiente de litigiosidade nas relações entre médico e paciente ${ }^{393}$. É claro que o escopo desta nova forma de abordar as questões de assistência ao fim da vida, ao envolver quesitos metajurídicos e

391. WILKINSON, Anne M., op. cit., p. 196.

392. KELLEHEAR, Allan. Advance care planning as a public health issue. In: ROGNE, Leah; McCUNE, Susana Lauraine. Advance care planning: communicating about matters of life and death, 2014, pp. $333 \mathrm{e}$ ss.

393. Idem. 
também extra-médicos, deve se revestir de uma adequada operacionalidade, eis que deve possuir pragmaticidade. $\mathrm{O}$ inverso seria torna-lo mera discussão metafísica ou filosófica. Assim, surgiram algumas possibilidades de formatação dessas expressões de valores, ainda que, reforce-se, o formalismo não é a tônica dos planejamentos antecipados. Eis algumas modalidades, elencadas por Anne Wilkinson ${ }^{394}$ :

1) "Five wishes": os "cinco desejos", que já citamos em linhas anteriores nessa pesquisa, possuem compatibilidade legal com as diretivas antecipadas de 40 estados norte-americanos, sendo consideradas uma evolução daquelas, e foram desenvolvidos em 1997. Por meio do documento, a pessoa pode expressar suas opções em relação a: pessoa(s) que pode(m) tomar decisões por ela em caso de incapacidade; tipos de tratamento que deseja e que rejeita; detalhes quanto ao conforto físico ambiental; companhia que deseja nos momentos finais da vida; orientações aos familiares quanto a providências de ordem geral a serem tomadas.

2) "Let me decide": programa canadense que procura orientar a forma de expressão da vontade dos pacientes por meio de um método "passo a passo", integrando os familiares e profissionais de saúde no processo. Foi formulado em 1994 e, ao contrário da modalidade anterior, já possui comprovada eficácia prática.

3) "The Respecting Choices programme": é o formato mais antigo, tendo sido criado em 1991, no estado de Wisconsin, nos Estados Unidos. É focado em comunidades urbanas, com o objetivo de orientar suas populações a elaborar documentos que se assemelhem a diretivas antecipadas de vontade, porém tem uma essência educativa, e não formal.

4) POLST (“The Physician Orders for Life-Sustaining Treatment”): surgiu em 1998, e consiste em um impresso sucinto, de uma página, direcionado para pessoas que já apresentem alguma patologia, com o intuito de dar diretrizes futuras a respeito de detalhes específicos do tratamento. Tem sido adotado no estado norte-americano de Oregon, com boa receptividade nos equipamentos de saúde. (vide Anexo 7)

394. WILKINSON, Anne M., op. cit., pp. 197-198. 


\section{Corolário: a perquirição dos valores do paciente direcionada à promoção da dignidade humana}

As diretivas antecipadas de vontade para o fim da vida trouxeram o mérito de dar vazão aos princípios da autonomia, principalmente, e também da não-maleficência, e como tal devem ser reconhecidas como benéficas ao ordenamento bioético, já que embutem nelas próprias aqueles princípios. No Brasil, esse "status" das diretivas vinha sendo cevado desde a Resolução 1805/2006 do Conselho Federal de Medicina, tomando impulso com o atual Código de Ética Médica, de 2009, e sendo formalmente entronizadas no ordenamento médico-ético com a Resolução 1995/2012 do Conselho Federal de Medicina.

Entretanto, as diretivas antecipadas, nos países que já as vivenciam há mais tempo, apresentam um desgaste decorrente de suas evidentes limitações e imperfeições, notadamente por insistirem em uma diretriz por demais legalista e formalista. Nesse sentido, as virtuais tentativas de imprimir uma indesejável cogência ao instituto, advogadas por alguns, acabariam por envenenar a própria possibilidade de sua aplicação. Isso porque a atividade médica deve caminhar nos liames éticos e técnicos imposta aos efetores dos atos terapêuticos pelos seus pares, sob a tutela de codificações médico-éticas consagradas, e não segundo linhas traçadas em um formulário, ou seguindo opções de representantes nem sempre comprometidos com o melhor interesse dos pacientes. A nova Resolução CFM 1995/2012 acerta nesse aspecto, ao deixar claro que as diretivas antecipadas de vontade devem servir como orientação, sem nunca cogitar em vincular o ato médico a elas. Considerá-las um mero passo no caminho de uma transformação em norma jurídica seria solapar seu próprio sentido, e contribuir para colocar uma pá de cal em um instituto impregnado de princípios tão nobres. Melhor faria o legislador, em sede normativa penal, se descriminalizasse de forma cabal a eutanásia passiva e a ortotanásia, o que abriria caminho para uma melhor utilização das diretivas, e limaria a antinomia que hoje existe entre norma ética e lei penal. Como ensina José de Faria Costa, a imbricação entre bioética e direito penal costuma caminhar em terreno pantanoso:

"O direito penal surge como um instrumento de realização de valores ou interesses sem um mínimo de aderência à materialidade da vida e antes com a finalidade lateral de, por meio do seu simbolismo, apaziguar as consciências, sobretudo as boas consciências. (...) A combinação da incerteza que envolve o nosso tempo com a própria incerteza larvar do direito penal a que se juntam as preocupações - logo, também incertezas - da própria 
bioética faz com que tenhamos um núcleo problemático em que o seu ou os seus pontos matriciais joguem no campo aberto da incerteza, 395 .

Reconhecendo essa incerteza, bem como as virtudes e fragilidades das diretivas antecipadas, tem surgido alternativas, em solo norte-americano, que caminham na direção de fazer valer as vontades dos pacientes, em situações de possível incapacidade para tomar decisões referentes à própria saúde. Ou seja, preservam o norte ético que emana das diretivas. Fazem-no, porém, de forma mais aberta, embasada nos valores de vida dos pacientes, e procurando envolver os entes queridos no processo. Nessa linha, os planejamentos antecipados de saúde jogam luzes sobre os aspectos valorativos da vida dos pacientes, tirando daí a base para futuras decisões terapêuticas no fim da vida.

Ao fazê-lo, incorporam a própria dignidade humana nas condutas, uma vez que escapam da superficialidade fria das diretivas. Também por isso, tornam-se mais palatáveis para os pacientes, e podem colocar no horizonte um estímulo para a expressão dessas vontades.

A fórmula não é perfeita, podendo se antever alguns possíveis problemas, como, por exemplo, a complexidade e o tempo necessários para a confecção de um planejamento antecipado de saúde. Entretanto, a mitigação da rigidez formal, inerente aos planejamentos antecipados, pode permitir a busca da melhor alternativa, adaptada às necessidades de cada pessoa.

Mais que isso: ao retirarem um desnecessário filtro legalista nos atos que cercam o processo da morte, promovem e enaltecem a saudável relação médico-paciente em momento tão delicado.

395. COSTA, José de Faria. Bioética e direito penal - reflexões possíveis em tempos de incerteza. In: Estudos em homenagem ao Prof. Doutor Jorge de Figueiredo Dias, vol. 1, 2009, pp. 117-118 


\section{CAPÍTULO VIII. CONCLUSÃO}

O instituto das diretivas antecipadas de vontade para o fim da vida, de origem norte-americana, e posteriormente recepcionado na Europa, foi acolhido no ordenamento ético-normativo nacional por meio da Resolução 1995/2012 do Conselho Federal de Medicina. As diretivas são um documento pelo qual uma pessoa capaz expressa a forma como deseja ser tratada em uma futura situação de assistência médica no fim da vida, na qual tenha se tornado física ou mentalmente incapaz de se manifestar. Nesse sentido, a pessoa autoriza ou desautoriza determinadas condutas médicas às quais esteja passível de ser submetida.

O foco das diretivas antecipadas são as situações atinentes à ortotanásia. Entretanto, a delimitação da ortotanásia com a eutanásia passiva, que é clara em sede

doutrinária, nem sempre o é em face de variadas situações clínicas. É patente que ambos os institutos são, em tese, passíveis de criminalização, segundo o Código Penal nacional. Assim, a plena eficácia das diretivas só se cristalizará com a expressa retirada da possibilidade de penalização da eutanásia passiva e ortotanásia no Brasil. Além disso, a norma ética das diretivas antecipadas de vontade para o fim da vida não pode se converter em lei que lhe atribua a qualidade de cogência em relação aos atos médicos, uma vez que deve respeitar a autonomia tanto do paciente quanto do médico.

As diretivas antecipadas de vontade trazem uma essência de respaldo da qualidade de vida, e por isso são bem-vindas. Sua utilização, porém, apresenta diversos aspectos complexos, demandando desafiadores ajustes para os estudiosos e operadores da Bioética. 


\section{REFERÊNCIAS BIBLIOGRÁFICAS}

ACTON, Ashton Q. Advances in terminal care research and application. Atlanta: Scholarly Editions, 2012.

ALVES, Cristiane Avancini. A conexão entre a autodeterminação e a formação familiar na esteira do princípio da responsabilidade. In: Bioética e responsabilidade. Rio de Janeiro: Editora Forense, 2009, pp. 113-144.

ARCOS, Maria Luisa. Notes on patients with disabilities autonomy in Spanish law. In: Medicine and law, volume 32, number 4, December 2013, pp. 601-612. Tel-Aviv, Israel: Probook.

ASHCROFT, Richard. Death policy in the United Kingdom. In: BLANK, Robert H. (ed.). End-of-life decision making: a cross-national study. Cambridge: Massachusetts Institute of Technology Press, 2005, pp. 197-218.

ASÚA, Luis Gimenez de. Liberdade de amar e direito a morrer, tomo II - eutanásia e endocrinologia. Belo Horizonte: Editora Mandamentos, 2003.

AZEVEDO, Antônio Junqueira de. Negócio jurídico - existência, validade e eficácia. São Paulo: Editora Saraiva, $4^{\mathrm{a}}$ edição, $7^{\mathrm{a}}$ tiragem, 2010.

AZEVEDO JÚNIOR, Renato. Diretivas antecipadas de vontade. In: Jornal do CREMESP, Editorial, p. 2, edição 296, setembro de 2012.

BALLARD, Clive; BANNISTER, Carol. Criteria for the diagnosis of dementia. In: Burns, Alistair; O’Brien, John; Ames, David (editors). Dementia. Boca Ratón, USA: Taylor \& Francis Group, 2005.

BARATTA, Alessandro. Les fonctions instrumentales et les fonctions symboliques du droit penal - pour une théorie du bien juridique. Traduction par Ch. Janssens. Deviance et Societé, Genève: Editions Médecine et Hygiène: 1991, v. 15, n.1, p. 1-25. 
BARBIERI, José Eduardo. Defesa do médico - responsabilidade civil e a inversão do ônus da prova sob a ótica da Bioética. Leme, SP: Editora de Direito, 2008.

BARROSO, Luís Roberto. A morte como ela é: dignidade e autonomia individual no final da vida. Revista da EMERJ, n. 50, v. 13, 2010, p. 19-63.

BARRY, Vincent. Bioethics in a cultural context - philosophy, religion, history, politics. Wadsworth: Cengage Learning, 2012.

BEAUCHAMP, Tom L.; CHILDRESS, James F. Principles of biomedical ethics. New York: Oxford University Press, $7^{\text {th }}$. Edition, 2013.

BECHARA, Ana Elisa Liberatore Silva. Da teoria do bem jurídico como critério de legitimidade do direito penal. Tese de livre-docência em Direito Penal, Faculdade de Direito da Universidade de São Paulo, 2010.

BENNETT, Richard G.; HALE, W. Daniel. Building healthy communities through medical - religious partnerships. Google e-livro: JHU Press, 2009.

BERGER, Arthur S. When life ends - legal overviews, medicolegal forms, and hospital policies. Westport: Praeger Publishers, 1995.

BERISTAIN, Antonio. Bioetica y nuevos deberes: derechos humanos. In: Revista Brasileira de Ciências Criminais, n. 13, v. 4, 1996, p. 21-31. São Paulo: Revista dos Tribunais.

BETANCOR, Juana Teresa. El testamento vital. Cuaderno Del Instituto Vasco de Criminologia. San Sebastián: 1995, n. 9, p. 97-112.

BILLIER, Jean-Cassien; MARYIOLI, Aglaé. História da filosofia do direito. Barueri: Editora Manole, 2005. 
BLAD, John R. Ceci n'est pás l'euthanasie: chronique du débat sur la mort douce aux Pays-Bas. Déviance et Societé, Genève: Editions Médecine et Hygiène: 1990, v. 15, n. 1, p. 93-121.

BLANCO, Mariano Casado. Aspectos éticos y legales de las instrucciones previas. Ciencia Forense, Espanha, 9-10/2009-2010: 135-148.

BOBBIO, Norberto. Teoria generale del diritto. Torino: G. Giappichelli Editore, 1993.

BONDOLFI, Alberto. The recente debate on advance directives in Switzerland. In: CLEMENTE, Carmine; CERSOSIMO, Giuseppina. Salute e società - the pre-chosen death: end-of life arrangements and instructions. Vol. X, n.1/2011, pp. 157- 162. Bologna: Franco Angeli, 2011.

BORGES, Roxana Cardoso Brasileiro. Direito de morrer dignamente: eutanásia, ortotanásia, consentimento informado, testamento vital, análise constitucional e penal e direito comparado. In: SANTOS, Maria Celeste Cordeiro Leite (org.). Biodireito: ciência da vida, os novos desafios. São Paulo: Editora Revista dos Tribunais, 2001, p. 283-305.

BRITO, José dos Santos Lopes de; RIJO, José Manuel Subtil. Estudo jurídico da eutanásia em Portugal - direito sobre a vida ou dever de viver? Coimbra: Livraria Almedina, 2000.

BRITT, L. D.; TRUNKEY, Donald D.; FELICIANO, David V. Acute care surgery principles and practice. New York: Springer Science + Business Media, 2007.

BUCCI, Maria Paula Dallari. O princípio da razoabilidade em apoio à legalidade. In: Cadernos de direito constitucional e ciência política. São Paulo: v. 4, n. 16, p. 173-177, jul./set. 1996.

BUKEN, Nuket Ornek; BALVESEN-ODABASI, Aysun. Physicians' attitudes at the end-of-life: a cross-cultural evaluation. In: Medicine and law, volume 32, number 4, December 2013, pp. 549-565. 
BULOS, Uadi Lammêgo. Curso de direito constitucional. 6. ed. São Paulo: Editora Saraiva, 2011.

CABRAL, Hildeliza Lacerda Tinoco Boechat. Eutanásia: dignidade da pessoa humana como fundamento ético e jurídico do direito à morte digna. In: Revista Magister de Direito Penal e Processual Penal, n. 43, v. 8, 2011, p. 58-83. São Paulo: Magister.

CAMARGO, Rosmari Aparecida Elias; CAMPOS, Roberto Augusto de Carvalho. A autonomia do médico e do paciente no atual Código de Ética Médica. In: PASCHOAL, Janaína Conceição; SILVEIRA, Renato de Mello Jorge (coords.). Livro homenagem a Miguel Reale Júnior. Rio de Janeiro: GZ Editora, 2014.

CANOTILHO, José Joaquim Gomes; MOREIRA, Vital. Fundamentos da Constituição. Coimbra: Editora Coimbra, 1991.

CANTOR, Norman. Advance directives and the pursuit of death with dignity. United States: Library of Congress Cataloging-in-Publication, 1993.

CARPER, Donald L.; McKINSEY, John A.; WEST, Bill W. Understanding the law. United States: Thomson Learning Inc., 2008.

CARROL, Roberta. Risk management handbook for health care organizations. San Francisco: Jossey-Bass, 2009.

CARVALHO, Gisele Mendes de. Ortotanásia é eutanásia, mas não é crime (Considerações a respeito da Resolução $n^{\circ}$ 1805/2006 do CFM e sua compatibilidade com o Código Penal). Disponível na Internet: WWW.ibccrim.org.br, 20.02.2008.

CEBUHAR, Jo Kline. Last things first, just in case...the practical guide to living wills and durable powers of attorney for health care. West des Moines, USA: Murphy Publishing, 2006. 
CHAPLEAU, Will. Manual de emergências: um guia prático para primeiros socorros. Rio de Janeiro: Elsevier, 2008.

CHAVES, Marianna. Advance directives: the consecration of autonomy and dignity of the human being. In: Medicine and law, volume 32, number 4, December 2013, pp. 515-523. Tel Aviv, Israel: Probook.

CLÉMENT, Catherine. A viagem de Theo - romance das religiões. São Paulo: Companhia das Letras, 1999.

CLOTET, Joaquim. Bioética - uma aproximação. Porto Alegre: EDIPUCRS, $2^{\mathrm{a}}$ edição, 2006.

COHEN-ALMAGOR, Raphael. Euthanasia in the Netherlands - the policy and practice of mercy killing. Dordrecht: Kluwer Academic Publishers, 2004.

COLLINS Jr., Evan R.; WEBER, Doron. The complete guide to living wills - how to safeguard your treatment choices. New York: Library of Congress Cataloging-inPublication, 1991.

CONSELHO REGIONAL DE MEDICINA DO ESTADO DE SÃO PAULO. Código de ética médica, 2009.

COSTA, José de Oliveira. Bioética e direito penal - reflexões possíveis em tempos de incerteza. In: Estudos em homenagem ao Prof. Doutor Jorge de Figueiredo Dias, v. 1, pp. 109-125. Coimbra: Coimbra Editora, 2009.

COSTA, Helena Regina Lobo da. A dignidade humana: teorias de prevenção geral positiva. São Paulo: Editora Revista dos Tribunais, 2008.

COWARD, Harold; SIDHU, Tejinder. Bioethics for clinicians: Hinduism and Sikhism. In: Canadian Medical Association Journal, October 31, 2000, pp. 1167-1170. www.cmaj.ca, acesso em 20/04/2014. 
DAAR, Abdallah S.; KHITAMY, A. Bioethics for clinicians: Islamic bioethics. In: Canadian Medical Association Journal, January 9, 2001, pp. 60-63. www.cmaj.ca, acesso em 20/04/2014.

DADALTO, Luciana. Testamento vital. Rio de Janeiro: Editora Lumen Juris, $2^{\text {a }}$ edição, 2013.

DALL'AGNOL, Darlei. Bioética. Rio de Janeiro: Jorge Zahar Ed., 2005.

DANTAS, Eduardo. Advance directives and living wills: the role of patient's autonomy in the Brazilian experience. In: Medicine and law, volume 32, number 4, December 2013, pp. 459-481. Tel-Aviv, Israel: Probook.

DANTAS, Ivo; ARAÚJO, Ionnara Vieira de. Dignidade da pessoa humana e bioética. In: Revista da Faculdade de Direito da UFG, n. 2, v. 32, 2008, p. 85-97.

DAVIDSON, Lauren. The art of autonomy: on the use and usefulness of the term in clinical bioethics. In: Medicine and law, volume 32, number 2, June 2013, pp. 153-162. Tel Aviv, Israel: Probook.

DE MARCO, Mário Alfredo; ABUD, Cristiane Curi; LUCCHESE, Ana Cecília; ZIMMERMANN, Vera Blondina. Psicologia médica - abordagem integral do processo saúde-doença. Porto Alegre: Artmed, 2012.

DIAS, Jorge de Figueiredo. A “ajuda médica à morte": uma consideração jurídicopenal. Revista Brasileira de Ciências Criminais, n. 100, v. 21, 2013, p. 15-40

DIAS, Jorge de Figueiredo. O problema da ortotanásia: introdução e sua consideração jurídica. In: Ciência penal. São Paulo: Editora Convívio, 1975, n.1, v. 2, p. 10-23.

DIAS, Roberto. O direito fundamental à morte digna: uma visão constitucional da eutanásia. Belo Horizonte: Editora Forum, 2012. 
DINIZ, Maria Helena. Curso de direito civil brasileiro - teoria geral do direito civil. São Paulo: Editora Saraiva, 25ª edição, 2008.

DORON, Israel; SODEN, Ann M. (editors). Beyond elder law - new directions in law and aging. Berlin: Springer, 2012.

DOUBLE, Richard. The non-reality of free will. New York: Oxford University Press, 1991.

DOUKAS, David John; REICHELL, William. Living wills and other advance directives for you and your family. Baltimore: The Johns Hopkins University Press, $2^{\text {nd }}$. Edition, 2007.

DRANE, James F. Clinical bioethics - theory and practice in medical-ethical decision making. Kansas City, United States: Sheed \& Ward, 1994.

DUARTE, Evangelina Castilho. O direito de morrer a propósito da Resolução $\mathrm{n}^{\circ}$ 1995/2012 do Conselho Federal de Medicina. In: Jurisprudência mineira - órgão oficial do Tribunal de Justiça do Estado de Minas Gerais, a. 63, v. 202, jul./ set. 2012, pp. 19-25. Belo Horizonte, MG.

DURAND, Guy; PERROTIN, Catharine. Contribution à la réflexion bioéthique dialogue France-Québec. Québec: Édition Fides, 1991.

D’URSO, Luiz Flávio Borges. A eutanásia no Brasil. Disponível na Internet: WWW.direitocriminal.com.br, 05.05.2001.

DWORKIN, Gerald. The theory and practice of autonomy. Cambridge: Cambridge University Press, edição digital, 2001. Acesso pelo site books.google.com.br (01/04/14).

DWORKIN, Gerald. Paternalismo. In: Revista justiça e sistema criminal: modernas tendências do sistema criminal, v. 4, n. 6, 2012, pp. 7-25. 
EDSEL, Ernest. The complete legal form book of living wills. United States: Folger Public Policy Research Center on Death and Dying, 2009.

EVANS, Abigail Rian. Is God still at the bedside? The medical, ethical, and pastoral issues of death and dying. Cambridge: Win B. Eerdmans Publishing, 2011.

FADEN, Ruth R.; BEAUCHAMP, Tom L. A history and theory of informed consent. New York: Oxford University Press, 1986.

FAGUNDES JÚNIOR, José Cabral Pereira. Limites da ciência e o respeito à dignidade humana. In: SANTOS, Maria Celeste Cordeiro (coord.). Biodireito: ciência da vida, os novos desafios. São Paulo: Revista dos Tribunais, 2001, p. 267-282.

FERRAJOLI, Luigi. Direito e razão - teoria do garantismo penal. 2. ed. São Paulo: Editora Revista dos Tribunais, 2006.

FERRAZ JÚNIOR, Tércio Sampaio. Introdução ao estudo do direito: técnica, decisão, dominação. 2. ed. São Paulo: Atlas, 1994.

FLIGHT, Myrtle. Law, liability \& ethics for medical office professionals. United States: Delmar Cengage Learning, $5^{\text {th }}$. Edition, 2011.

FOSTER, Steve. Human rights and civil liberties. New York: Oxford University Press, 2008 .

FRANÇA, Genival Veloso de. Os riscos da medicina baseada em evidências. In: Bioética, n. 1, v. 11, 2003, pp. 23-32.

FRANCO, Alberto Silva. A eutanásia passiva no novo Código Penal. Boletim IBCCrim, n. 5, junho/1993. 
FREIRE, Paula Vaz. A regulação da saúde: uma perspectiva comportamental. In: ALONSO, Ricardo Pinha; KAZMIERCZAK, Luiz Fernando. Estudos contemporâneos de bioética e biodireito. São Paulo: Editora Letras Jurídicas, 2013.

FURNARI, Marianna Gensabella. Alle frontiere della vita. Eutanasia ed etica del morire. Messina: Rubbertino Editore, 2003.

GALHA, Lucília. Morte assistida - temos o direito de escolher a forma como morremos? - os desejos e os receios de sete doentes portugueses confrontados com o fim. Alfragide, Portugal: Oficina do livro, 2013.

GALLO, Nancy R. Elder law. New York: Delmar Cengage Learning, 2009.

GALLETTI, Matteo; ZULLO, Silvia. La vita prima della fine: lo stato vegetativo tra etica, religione e diritto. Firenze: Firenze University Press, 2008.

GALLIN, John I.; OGNIBENE, Frederick P. Principles and practice of clinical research. London, UK: Elsevier Inc., Third edition, 2012.

GALOFARO, Francesco. Eluana Englaro: la contesa sulla fine della vita. Roma: Meltemi Editore, 2009.

GARCIA, Eusebio Fernandez. Dignidad humana y eutanasia. In: ROIG, Javier Ansuátegui (coord.). Problemas de la eutanasia. Madrid: Dykinson, 1999.

GARCIA, Iberê Anselmo. Aspectos médicos e jurídicos da eutanásia. Revista Brasileira de Ciências Criminais, n. 67, v. 15, 2007, p. 253-275.

GARRAFA, Volnei; PESSINI, Leo. Bioética: poder e injustiça. São Paulo: Edições Loyola, $2^{\mathrm{a}}$ edição, 2004.

GHERARDI, Carlos R. Vida y muerte en terapia intensiva - estrategias para conocer y participar en las decisiones. Buenos Aires: Editorial Biblos, 2007. 
GIGNON, Maxime; GANRY, Olivier; JARDÉ, Olivier; MANAOUIL, Cécile. Finding a balance between patients' rights, responsibilities and obligations. In: Medicine and law, volume 32, number 3, September 2013, pp. 319-326. Tel Aviv, Israel: Probook.

GODKIN, M. Dianne. Living will, living well - reflections on preparing an advance directive. Alberta, Canada: The University of Alberta Press, 2008.

GOLDSAND, Gary; ROSENBERG, Zahava R. S.; GORDON, Michael. Bioethics for clinicians: Jewish bioethics. In: Canadian Medical Association Journal, January 23, 2001, pp. 219-222. www.cmaj.ca, acesso em 20/04/2014.

GOMES, Luiz Flávio. Ortotanásia: morte digna? In: Revista Magister de Direito Penal e Processual Penal, n. 43, v. 8, 2011, p. 56-57.

GOMES, Mariângela Gama de Magalhães. O princípio da proporcionalidade no direito penal. São Paulo: Editora Revista dos Tribunais, 2003.

GOMES, Mariângela Gama de Magalhães. O valor normativo da jurisprudência penal. São Paulo: Tese de doutorado, Faculdade de Direito da USP, 2007.

GOMES, Orlando. Contratos. Rio de Janeiro: Editora Forense, 26ª edição, 2009.

GONÇALVES, Carlos Roberto. Direito das sucessões. São Paulo: Editora Saraiva, $5^{\text {a }}$ edição, 2011.

GONZÁLEZ, Miguel Ángel Sánchez. Testamentos vitais e diretivas antecipadas. In: RIBEIRO, Diaulas Costa (org.). A relação médico-paciente: velhas barreiras, novas fronteiras. São Paulo: Centro Universitário São Camilo, 2010, pp. 109-163.

GONZÁLEZ ALCÁNTARA, Juan Luis. Testamento vital y eutanásia. In: Iter criminis: Revista de ciencias penales, n. 2, 2008, p. 11-56.

GRAU, Eros Roberto. Equidade, razoabilidade e proporcionalidade. In: Revista do advogado. São Paulo: n. 78, v. 24, 2004, p. 27-30. 
GRECO, Alessandra Orcesi Pedro. A autocolocação da vítima em risco. São Paulo: Editora Revista dos Tribunais, 2004.

GRECO, Peter J. et al. The Patient Self-Determination Act and the future of advance directives. In: JECKER, Nancy S.; JONSEN, Albert R.; PEARLMEN, Robert A. Bioethics - an introduction to the history, methods and practice. Sudbury, United States: Jones and Bartlett Publishers, 1997, pp. 324-330.

GRECO FILHO, Vicente. Manual de processo penal. 8. ed. São Paulo: Saraiva, 2010.

GRECO FILHO, Vicente. GRECO, Alessandra Orcesi Pedro. A prova penal no contexto da dignidade da pessoa humana. In: MIRANDA, Jorge; SILVA, Marco Antônio Marques da (coord.). Tratado luso-brasileiro da dignidade humana. São Paulo: Quartier Latin, 2a edição, 2009, p. 989-1003.

GUIMARÃES, Marcello Ovídio Lopes. Eutanásia: novas considerações penais. Leme: J. H. Mizuno Editora e Distribuidora, 2011.

GUINN, Keydron Kordell. Physicians' perspectives on discussing patient advance directives. Dissertation (Doctor of Philosophy), Wayne State University, Detroit, Michigan, 2008.

GUVEN, T. Advance directives in Turkey's cultural context: examining the potential benefits for the implementation of patient rights. In: Bioethics, 2010; 24(3): 127-33.

HABERMAS, Jürgen. A inclusão do outro. São Paulo: Edições Loyola, $3^{\text {a }}$ edição, 2007.

HALES, Robert E.; YUDOFSKY, Stuart C.; GABBARD, Glen O. (ed.) The American Psychiatric Publishing textbook of psychiatry. Arlington, United States: American Psychiatric Publishing, $5^{\text {th }}$. Edition, 2008.

HASSEMER, Winfried. Direito penal libertário. Belo Horizonte: Editora Del Rey, 2007. 
HIRSCH, Hans Joachin. Acerca Del estado actual de la discusión sobre el concepto de bien jurídico. In: Modernas tendências em la ciencia del derecho penal y en la criminologia. Madrid: Universidad Nacional de Educación a Distancia, 2000, p. 371387.

JÄÄSKELÄINEN, Federico de Montalvo. Muerte digna y Constituición: los límites del testamento vital. Madrid: R. B. Servicios Editoriales, 2009.

JECKER, Nancy S.; JONSEN, Albert R.; Pearlmen, Robert A. Bioethics - an introduction to the history, methods, and practice. Sudbury, United States: Jones \& Bartlett Learning, Third edition, 2012.

JONSEN, Albert; SIEGLER, Mark; WINSLADE, William J. Clinical ethics $-a$ practical approach to ethical decisions in clinical medicine. United States: McGraw Hill Companies, $7^{\text {th }}$ Edition, 2010.

KEHL, Maria Rita. Viver é conviver. In: PESSINI, Leo; BARCHIFONTAINE, Christian de Paul. Problemas atuais de bioética. São Paulo: Edições Loyola, 8 a edição, 2008 .

KELLEAR, Allan. Advance care planning as a public health issue. In: ROGNE, Leah; McCUNE, Susana Lauraine. Advance care planning: communicating about matters of life and death. New York: Springer Publishing Company, 2014, pp. 333-345.

KELSEN, Hans. Teoria pura do direito. São Paulo: Editora Martins Fontes, $7^{\text {a }}$ edição, 2006.

KILBURN, Julian. Answer plans for the Medical Research Council of General Practitioners. Oxford, United Kingdom: BIOS Scientific Publishers, 2005.

KING, Nancy M. P. Making sense of advance directives. Washington, D. C.: Georgetown University Press, 1996. 
KOLB, Patricia. Social work practice with ethnically and racially diverse nursing home residents and their families. New York: Columbia University Press, 2007.

KRESS, Hartmut. Ética médica. São Paulo: Edições Loyola, 2008.

KROHM, Carol; SUMMERS, Scott. Advance health care directives - a handbook for professional. Chicago: American Bar Association, 2002.

KUCZEWSKI, Mark G.; POLANSKI, Ronald. Bioethics - ancient themes in contemporary issues. Massachusetts: MIT Press, 2002.

LIMA, Alberto Jorge Correia de Barros. Direito penal constitucional. São Paulo: Editora Saraiva, 2012.

LIMA, Carlos Vital Tavares Corrêa (rel.). Exposição de motivos da Resolução 1995/12 do Conselho Federal de Medicina, 2012.

LINCOLN, Nadina B.; KNEEBONE, Ian I.; MACNIVEN, Jamie A. B.; MORRIS, Reg C. Psychological management of stroke. West Sussex, UK: Wiley-Blackwell, 2012.

LOPES, Maurício Antonio Ribeiro. Critérios constitucionais de determinação dos bens jurídicos penalmente relevantes. Tese de livre-docência em Direito Penal, Faculdade de Direito da Universidade de São Paulo, 1999.

LUELMO, Andrés Domínguez. Derecho sanitario y responsabilidad médica comentarios a la Ley 41/2002, de 14 de noviembre, sobre derechos del paciente, información y documentación clínica. Valladolid: Editorial Lex Nova, 2a edición, 2007.

MANTOVANI, Ferrando. Aspetti giuridici della eutanásia. In: Rivista Italiana di Diritto e Procedura Penale, v.31, 1988, p. 448-469. Milano: Dott. A. Giuffrè Editore.

MARCÃO, Renato Flávio. Homicídio eutanásico: eutanásia e ortotanásia no Anteprojeto do Código Penal. Disponível na Internet: WWW.ibccrim.org.br, 05.06.2002. 
MASCARO, Alysson Leandro. Filosofia do direito. São Paulo: Editora Atlas, 2010.

McCULLOUGH, Laurence B.; JONES, James W.; BRODY, Baruch A. Surgical ethics. New York: Oxford University Press, 1998.

McDOUGALL, Jennifer Fecio; GORMAN, Martha. Euthanasia: a reference handbook. Santa Barbara: ABC-CLIO Inc, Second edition, 2008.

MEISEL, Alan. Legal aspects of end-of-life decisión making. In: STEINBERG, Maurice D.; YOUNGNER, Stuart J. End-of-life decisions: a psychosocial perspective. Washington, D.C.: American Psychiatric Press, 1998.

MELIÁ, Manuel Cancio. Conducta de la víctima y imputación objetiva em derecho penal. Barcelona: J. M. Bosch Editor, 2001.

MELLO, Marcos Bernardes de. Teoria do fato jurídico - plano da validade. São Paulo: Editora Saraiva, $8^{\mathrm{a}}$ edição, 2008.

MONACO, Gustavo Ferraz de Campos. Direitos da personalidade da pessoa física. In: HIRONAKA, Giselda M. F. Novaes. Direito civil - teoria geral, pp. 49-52. São Paulo: Editora Revista dos Tribunais, 2008.

MONAGLE, John F.; THOMASMA, David C. Health care ethics - critical issues for the 21st Century. Sudbury, United States: Jones and Bartlett Publishers, 2005.

MONNIER, Sophie. Les comités d'éthique et le droit - éléments d'analyse sur le système normatif de la bioéthique. Paris: Editions L'Harmattan, 2005.

MORAES, Alexandre de. Direito constitucional. São Paulo: Editora Atlas, 9a edição, 2001. 
MOREIRA, Sara Leitão. Brief notes on the Portuguese criminal regime of homicide upon request of the victim and physician assisted suicide. In: Medicine and law, volume 32, number 4, December 2013, pp. 527-541. Tel Aviv, Israel: Probook.

NÁCUL, Flávio et al. Manual de medicina intensiva. Rio de Janeiro: Elsevier Editora, 2009.

NUCCI, Guilherme de Souza. Manual de direito penal. São Paulo: Editora Revista dos Tribunais, $8^{\mathrm{a}}$ edição, 2012.

NUNES, Luiz Antônio Rizzatto. A intuição e o direito - um novo caminho. Belo Horizonte: Editora Del Rey, 1997.

NUNES, Rui; MELO, Helena Pereira de. Testamento vital. Coimbra: Edições Almedina, 2011.

NYS, Herman. Medical law in Belgium. Alphen aan den Rijin, The Netherlands: Kluwer Law International, 2010.

OLICK, Robert. Taking advance directives seriously - prospective autonomy and decisions near the end of life. Washington, D. C.: Georgetown University Press, 2001.

OLIVEIRA, Damião Alexandre Tavares. Dignidade da pessoa humana, cuidados paliativos e ortotanásia: a visão de um juiz. Belo Horizonte: Jurisprudência Mineira, n. 203, v. 63, 2012, p. 32-39.

OLIVEIRA, Flávio Luís de. Princípio do acesso à justiça. In: Oliveira Neto, Olavo de; Lopes, Maria Elizabeth de Castro (orgs.). Princípios processuais civis na Constituição. Rio de Janeiro: Elsevier Editora, 2008, p. 79-100.

ORGANIZAÇÃO MUNDIAL DA SAÚDE. Classificação internacional de funcionalidade, incapacidade e saúde, 2001. 
O'ROURKE, Kevin D.; BOYLE, Philip J. Medical ethics - sources of catholic teachings. Georgetown: Georgetown University Press, $4^{\text {th }}$. Edition, 2011.

OWUSU-DAPAA, Ernest. Euthanasia, assisted dying and the right to die in Ghana: a socio-legal analysis. In: Medicine and Law, v. 32, n. 4, December 2013, pp. 587-599. Tel-Aviv, Israel: Probook.

PASSARELLI, Maria Cristina Guerra; CARVALHO, Flávio Pedreira de Freitas. Farmacoterapia: iatrogenias. In: LOPES, Antônio Carlos. Diagnóstico e tratamento, volume 2, pp. 797 e ss. São Paulo: Editora Manole, 2006.

PAVIA, Marie-Luce. La découverte de la dignité de la personne humaine. In: PAVIA, Marie-Luce; REVET, Thierry. La dignité de la personne humaine. Paris: Economica, 1999, p. 3-23.

PEREIRA, André Dias. Living will and health care proxy - the Portuguese legal situation. In: Medicine and law, volume 32, number 4, December 2013, pp. 497-502. Tel Aviv, Israel: Probook.

PESSINI, Leocir; BARCHIFONTAINE, Christian de Paul. Problemas atuais de bioética. São Paulo: Edições Loyola, 8a edição, 2008.

PETERKOVÁ, Helena. Previously expressed wishes in the Czech Republic - a missed chance of the Czech legislator. In: Medicine and Law, number 4, volume 32, December 2013, p. 429-440. Tel Aviv, Israel: Probook.

PETRINOVICH, Lewis. Living and dying well. New York: Plenum Press, 1996.

PICCINI, Cleiton Francisco et. al. Testamento vital na perspectiva de médicos, advogados e estudantes. In: Bioethikos, out/dez 2011, n. 4, pp. 384-391.

PIERANGELI, José Henrique. O consentimento do ofendido na teoria do delito. 3. ed. São Paulo: Editora Revista dos Tribunais, 2001. 
PITHAN, Livia Haygert. A dignidade humana como fundamento jurídico das "ordens de não-ressuscitação” hospitalares. Porto Alegre: EDIPUCRS, 2004.

PRADO, Luiz Regis. Curso de direito penal brasileiro, vol. 1 , parte geral, arts. $1^{o} a$ 120. 8. ed. São Paulo: Editora Revista dos Tribunais, 2008.

PURTILLO, Ruth B.; HAVE, Henk A. M. J. Ethical foundations of palliative care for Alzheimer disease. Baltimore: The Johns Hopkins University Press, 2010.

QUINN, Joseph F. Dementia. West Sussex, UK: John Wiley and Sons Ltd., 2014.

RAMOS, Elival da Silva. A exigência de proporcionalidade no controle abstrato de normas brasileiro. In: Revista Mestrado em Direito: direitos humanos fundamentais. Osasco, EDIFIEO: n.1, v. 14, 2010, p. 115-139.

RICH, Ben A. Strange bedfellows: how medical jurisprudence has influenced medical ethics and medical practice. New York: Kluwer Academic/ Plenum Publishers, 2001.

RIVACOBA Y RIVACOBA, Manuel de. Cambio de sentido en la protección y el concepto penal de la vida humana. In: Doctrina penal: teoria y pratica en las ciencias penales, v. 12, 1989, p. 287-294.

ROSENBAUM, Ernest H.; ROSENBAUM, Isadora. Everyone's guide to cancer supportive care - a comprehensive handbook for patients and their families. Kansas City, United States: Andrews McMeel Universal Company: 2005.

ROXIN, Claus. A apreciação jurídico-penal da eutanásia. Revista Brasileira de Ciências Criminais, n.32, v. 8, 2000, p. 9-38.

ROXIN, Claus. Estudos de direito penal. Rio de Janeiro: Renovar, 2006.

SAITTA, Nicole Marie; HODGE Jr., Samuel. What are the consequences of disregarding a "do not resuscitate directive" in the United States? In: Medicine and law, volume 32, number 4, December 2013, pp. 441-458. Tel Aviv, Israel: Probook Ltd. 
SAMPAIO, José Adércio Leite. Constituição e crise política. Belo Horizonte: Editora Del Rey, 2006.

SANTOS, Maria Celeste Cordeiro Leite dos. Contornos atuais da eutanásia e da ortotanásia: bioética e biodireito, a necessidade do controle social das técnicas médicas. In: Boletim do Instituto Manoel Pedro Pimentel, 2000, São Paulo, p. 20-26.

SARLET, Ingo Wolfgang. Dignidade da pessoa humana e direitos fundamentais na Constituição Federal de 1988. Porto Alegre: Livraria do Advogado Editora, 2002.

SCAFF, Fernando Campos. Direito à saúde no âmbito privado: contratos de adesão, planos de saúde e seguro-saúde. São Paulo: Saraiva, 2010.

SCHERMER, Maartje. The different faces of autonomy - patient autonomy in ethical theory and hospital practice. Dordrecht: Kluwer Academic Publishers, 2002.

SERRÃO, Daniel. A Convenção Europeia de Bioética e a prática médica em Portugal. Acesso virtual em www.danielserrao.com/gca/index.php?id=109 em 10/04/2014.

SILVA, José Afonso da. Comentário contextual à Constituição. São Paulo: Malheiros Editores, $7^{\mathrm{a}}$ edição, 2010.

SILVEIRA, Renato de Mello Jorge. Bem jurídico-penal: leituras conflituosas. In: SAAD-DINIZ, Eduardo; POLAINO-ORTS, Miguel (Orgs.). Teoria da pena, bem jurídico e imputação. São Paulo: Liber Ars, 2012, p. 129-147.

SINGER, Peter. Ética prática. São Paulo: Martins Fontes, $3^{a}$ edição, 2002.

SINGER, Peter; VIENS, A. M. The Cambridge textbook of bioethics. Cambridge: Cambridge University Press, 2008.

SOUZA, Carlos Alberto Crespo de. Avanços em clínica neuropsiquiátrica. Porto Alegre: Editora Age, 2005. 
SOUZA, Neri Tadeu Camara. Eutanásia: aspectos jurídicos. Disponível na Internet: WWW.ibccrim.org.br, 28.01.2005.

STEWART, Cameron. Advance directives: disputes and dilemmas. In: FRECKELTON, Ian; PETERSEN, Kerry (editors). Disputes and dilemas in health law. Sydney: The Federation Press, 2007.

STOPPE, Gabriela (ed.). Competence assessment in dementia. Mörlenbach, Germany: Springer-Verlag, 2008.

SURESH, Maya. Shnider and Levinson's anesthesia for obstetrics. Baltimore: Lippincott Williams \& Wilkins, $5^{\text {th }}$. Edition, 2013.

SWOTA, Alissa Hurwitz. Culture, ethics, and advance care planning. Plymouth, United Kingdom: Lexington Books, 2009.

TOLLEFSEN, Christopher. Artificial nutrition and hydration - the new catholic debate. Dordrecht, Netherlands: Springer, 2008.

ULRICH, Lawrence P. The Patient Self-determination Act-meeting the challenges in patient care. Washington, D. C.: Georgetown University Press, 1999.

VALENTE, Valentim. Anita Garibaldi, heroína por amor. São Paulo: Editora Soma, 1949.

VENOSA, Sílvio de Salvo. Direito civil - parte geral. São Paulo: Editora Atlas, $8^{\text {a }}$ edição, 2008.

VENTURA, Carla A. A.; GALLAGHER, Ann; JAGO, Robert; MENDES, Isabel A. C. Rethinking ethical and legal issues at the end of life in the UK and Brazil: a role for solidarity? In: Medicine and law, volume 32, number 4, December 2013, pp. 481-496. Tel-Aviv, Israel: Probook. 
VESHI, Denard. Ethical and legal issues in cases of withdrawing treatment from an incompetent patient in Italy. In: Medicine and law, volume 32, number 4, December 2013. Tel Aviv, Israel: Probook.

WEISS, Raul; DAOUD, Emile G. Sudden cardiac death: heart failure clinics. Philadelphia, United States: W. B. Saunders Company, 2011.

WHITE, Barbara; TRUAX, Deborah. The nurse practitioner in long-term care: guidelines for clinical practice. Sudbury, United States: Jones and Bartlett Publishers, 2007.

WILBER, Ken. Psicologia integral - consciência, espírito, psicologia, terapia. São Paulo: Editora Cultrix, 2007.

WILKINSON, Anne M. Advance directives and Advance Care Planning: the US experience. In: THOMAS, Keri; LOBO, Ben (ed.). Advance Care Planning in end of life care. New York: Oxford University Press, 2011, pp. 189-204.

WOO, Jean. Aging in Hong Kong - a comparative perspective. New York: Springer Science + Business Media, 2013 (e-book).

YOUNG, Carolyn; KOOPSEN, Cyndie; FARB, Daniel. End of life care issues guidebook. Los Angeles: University of Health Care/ University of Business, 2005.

ZAFFARONI, Eugenio Raul; PIERANGELI, José Henrique. Manual de direito penal brasileiro, volume 1, parte geral. 7. ed. São Paulo: Editora Revista dos Tribunais, 2007. 


\section{ANEXOS}




\title{
Anexo 1
}

\author{
H.R.4449 -- Patient Self Determination Act of 1990 (Introduced in House - IH) \\ 101st CONGRESS \\ 2d Session \\ H. R. 4449
}

To amend titles XVIII and XIX of the Social Security Act to require providers of services and health maintenance organizations under the medicare and medicaid programs to assure that individuals receiving services will be given an opportunity to participate in and direct health care decisions affecting themselves.

\section{IN THE HOUSE OF REPRESENTATIVES}

April 3, 1990

Mr. LEVIN of Michigan (for himself, Mr. SWIFT, Mr. MOODY, Mr. MCDERMOTT, and Mr. FAUNTROY) introduced the following bill; which was referred jointly to the Committees on Ways and Means and Energy and Commerce

A BILL

To amend titles XVIII and XIX of the Social Security Act to require providers of services and health maintenance organizations under the medicare and medicaid programs to assure that individuals receiving services will be given an opportunity to participate in and direct health care decisions affecting themselves.

Be it enacted by the Senate and House of Representatives of the United States of America in Congress assembled,

SECTION 1. SHORT TITLE.

This Act may be cited as the 'Patient Self Determination Act of 1990'.

\section{SEC. 2. MEDICARE PROVIDER AGREEMENTS ASSURING THE IMPLEMENTATION OF A PATIENT'S RIGHT TO PARTICIPATE IN AND DIRECT HEALTH CARE DECISIONS AFFECTING THE PATIENT.}

(a) IN GENERAL- Section 1866(a)(1) of the Social Security Act (42 U.S.C. 1395cc(a)(1)), as amended by section 6112 of the Omnibus Budget Reconciliation Act of 1989, is amended--

(1) by striking 'and' at the end of subparagraph (O),

(2) by striking the period at the end of subparagraph (P) and inserting ', and', and

(3) by inserting after subparagraph $(\mathrm{P})$ the following new subparagraph:

(Q) in the case of hospitals, skilled nursing facilities, home health agencies, and hospice programs, to maintain written policies and procedures with respect to all individuals receiving medical care by or through the provider--

(i) to inform such individuals of an individual's rights under State law (whether statutory or as recognized by the courts of the State) to make decisions concerning such medical care, including the right to accept or refuse medical or surgical treatment and the right to formulate advanced directives recognized under State law relating to the provision of care when such individuals are incapacitated (such a directive in this subparagraph referred to as an 'advanced directive'), such as through--

(I) the appointment of an agent or surrogate to make health care decisions on behalf of such an individual, and 
(II) the provision of written instructions concerning the individual's health care (including instructions for the disposition of organs);

(ii) to inquire periodically (and to document in the individual's medical record) whether or not the individual has executed an advanced directive and to document in such record the individual's wishes (if any) with respect to such medical care;

(iii) not to deny the initial provision of care or otherwise discriminate against an individual based on whether or not the individual has executed an advanced directive;

(iv) to ensure that legally valid advanced directives and wishes otherwise documented under clause (ii) are implemented to the extent permissible under State law, including such provisions of State law as relate to the transfer of an individual in the case of a provider which, as a matter of conscience, cannot implement the wishes of the individual; and

(v) to provide (individually or with others) for educational programs for staff, individuals receiving medical care by or through the provider, and the community on ethical issues concerning patient self determination and concerning advance directives respecting such care.'.

(b) APPLICATION TO HEALTH MAINTENANCE ORGANIZATIONS- Section 1876(c) of such Act (42 U.S.C. $1395 \mathrm{~mm}(\mathrm{c})$ ) is amended by adding at the end the following new paragraph:

(8) A contract under this section shall provide that the eligible organization shall meet the requirements of section 1866(a)(1)(Q) in the same manner as they apply to hospitals.'.

(c) Effective Dates-

(1) The amendments made by subsection (a) shall apply with respect to services furnished on or after the first day of the first month beginning more than 180 days after the date of the enactment of this Act.

(2) The amendment made by subsection (b) shall apply to contracts under section 1876 of the Social Security Act as of the first day of the first month beginning more than 180 days after the date of the enactment of this Act.

\section{SEC. 3. MEDICAID STATE PLANS ASSURING THE IMPLEMENTATION OF A PATIENT'S RIGHT TO PARTICIPATE IN AND DIRECT HEALTH CARE DECISIONS AFFECTING THE PATIENT.}

(a) IN GENERAL- Section 1902(a) of the Social Security Act (42 U.S.C. 1396a(a)), as amended by section 6406(a) of the Omnibus Budget Reconciliation Act of 1989, is amended--

(1) by striking 'and' at the end of paragraph (52),

(2) by striking the period at the end of paragraph (53) and inserting '; and', and

(3) by inserting after paragraph (53) the following new paragraph:

(54) provide that each hospital, nursing facility, home health agency, hospice program, or health maintenance organization receiving funds under the plan shall maintain written policies and procedures with respect to all individuals receiving medical care by or through the provider or organization--

(A) to inform such individuals of an individual's rights under State law (whether statutory or as recognized by the courts of the State) to make decisions concerning such medical care, including the right to accept or refuse medical or surgical treatment and the right to formulate advanced directives recognized under State law relating to the provision of care when such individuals are incapacitated (such a directive in this paragraph referred to as an 'advanced directive'), such as through--

(i) the appointment of an agent or surrogate to make health care decisions on behalf of such an individual, and

(ii) the provision of written instructions concerning the individual's health care (including instructions for the disposition of organs);

(B) to inquire periodically (and to document in the individual's medical record) whether or not the individual has executed an advanced directive 
and to document in such record the individual's wishes (if any) with respect to such medical care;

(C) not to deny the initial provision of care or otherwise discriminate against an individual based on whether or not the individual has executed an advanced directive;

(D) to ensure that legally valid advanced directives and wishes otherwise documented under subparagraph (B) are implemented to the extent permissible under State law, including such provisions of State law as relate to the transfer of an individual in the case of a provider or organization which, as a matter of conscience, cannot implement the wishes of the individual; and

(E) to provide (individually or with others) for educational programs for staff, individuals receiving medical care by or through the provider or organization, and the community on ethical issues concerning patient self determination and concerning advance directives respecting such care.'.

(b) EFFECTIVE DATE- The amendments made by subsection (a) shall apply with respect to services furnished on or after the first day of the first month beginning more than 180 days after the date of the enactment of this Act.

\section{SEC. 4. STUDY TO ASSESS IMPLEMENTATION OF A PATIENT'S RIGHT TO PARTICIPATE IN AND DIRECT HEALTH CARE DECISIONS AFFECTING THE PATIENT.}

(a) IN GENERAL- The Secretary of Health and Human Services shall (subject to subsection (b)) enter into an agreement with the Institute of Medicine of the National Academy of Sciences to conduct a study with respect to the implementation of directed health care decisions. Such study shall--

(1) evaluate the experience of practitioners, providers, and government regulators experienced in complying with the requirement imposed by the amendments made by sections 2(a) and 3(a); and

(2) investigate methods of making decisions reached by a patient or nursing home resident transferrable, so that the wishes of the patient or resident can be known and respected in other health care settings to which the patient or resident may be transferred or discharged.

(b) ARRANGEMENTS FOR STUDY- The Secretary shall request the Institute of Medicine of the National Academy of Sciences to submit an application to conduct the study described in subsection (a). If the Institute submits an acceptable application, the Secretary shall enter into an appropriate arrangement with the Academy for the conduct of the study within 28 days of the date the application is received. If the Institute does not submit an acceptable application to conduct the study, the Secretary may request one or more appropriate nonprofit private entities to submit an application to conduct the study and may enter into an appropriate arrangement for the conduct of the study by the entity which submits the best acceptable application.

(c) REPORT- The results of the study shall be reported to Congress and the Secretary by not later than 4 years after the date of the enactment of this Act. Such report shall include such recommendations for legislation as may be appropriate to carry out further the purpose of this Act.

\section{SEC. 5. PUBLIC EDUCATION DEMONSTRATION PROJECT.}

The Secretary of Health and Human Services, no later than 6 months after the date of the enactment of this Act, shall develop and implement a demonstration project in selected States to inform the public of the option to execute advance directives and of a patient's right to participate in and direct health care decisions. The Secretary shall report to Congress on the results of the project and on whether such project should be expanded to cover all the States. 


\section{Anexo 2}

INSTRUMENTO de Ratificación del Convenio para la protección de los derechos humanos y la dignidad del ser humano con respecto a las aplicaciones de la Biología y la Medicina (Convenio relativo a los derechos humanos y la biomedicina), hecho en Oviedo el 4 de abril de 1997.

Publicado en:

«BOE» núm. 251, de 20 de octubre de 1999, páginas 36825 a 36830 (6 págs.)

\section{TEXTO}

\section{JUAN CARLOS I}

\section{REY DE ESPAÑA}

Por cuanto el día 4 de abril de 1997, el Plenipotenciario de España, nombrado en buena y debida forma al efecto, firmó en Oviedo el Convenio para la protección de los derechos humanos y la dignidad del ser humano con respecto a las aplicaciones de la Biología y la Medicina (Convenio relativo a los derechos humanos y la biomedicina), hecho en el mismo lugar y fecha, Vistos y examinados el Preámbulo y los treinta y ocho artículos de dicho Convenio, Concedida por las Cortes Generales la autorización prevista en el artículo 94.1 de la Constitución, Vengo en aprobar y ratificar cuanto en el mismo se dispone, como en virtud del presente lo apruebo y ratifico, prometiendo cumplirlo, observarlo y hacer que se cumpla y observe puntualmente en todas sus partes, a cuyo fin, para su mayor validación y firmeza, Mando expedir este Instrumento de Ratificación firmado por Mí, debidamente sellado y refrendado por el infrascrito Ministro de Asuntos Exteriores.

Dado en Madrid a 23 de julio de 1999.

JUAN CARLOS R.

El Ministro de Asuntos Exteriores,

ABEL MATUTES JUAN

CONVENIO PARA LA PROTECCIÓN DE LOS DERECHOS HUMANOS Y LA DIGNIDAD DEL SER HUMANO CON RESPECTO A LAS APLICACIONES DE LA BIOLOGÍA Y LA MEDICINA

Convenio relativo a los derechos humanos y la biomedicina

\section{PREÁMBULO}

Los Estados miembros del Consejo de Europa, los demás Estados y la Comunidad Europea, signatarios del presente Convenio;

Considerando la Declaración Universal de los Derechos Humanos, proclamada por la Asamblea General de las Naciones Unidas el 10 de diciembre de 1948;

Considerando el Convenio para la Protección de los Derechos Humanos y de las Libertades Fundamentales, de 4 de noviembre de 1950;

Considerando la Carta Social Europea de 18 de octubre de 1961;

Considerando el Pacto Internacional de derechos civiles y políticos y el Pacto Internacional de derechos económicos, sociales y culturales de 16 de diciembre de 1966;

Considerando el Convenio para la Protección de las Personas con respecto al tratamiento automatizado de datos de carácter personal de 28 de enero de 1981;

Considerando igualmente la Convención sobre los Derechos del Niño, de 20 de noviembre de 1989; 
Considerando que la finalidad del Consejo de Europa es la de conseguir una unión más estrecha entre sus miembros y que uno de los medios para lograr dicha finalidad es la salvaguardia y el fomento de los derechos humanos y de las libertades fundamentales;

Conscientes de los rápidos avances de la biología y la medicina,

Convencidos de la necesidad de respetar al ser humano a la vez como persona y como perteneciente a la especie humana y reconociendo la importancia de garantizar su dignidad;

Conscientes de las acciones que podrían poner en peligro la dignidad humana mediante una práctica inadecuada de la biología y la medicina;

Afirmando que los progresos en la biología y la medicina deben ser aprovechados en favor de las generaciones presentes y futuras;

Subrayando la necesidad de una cooperación internacional para que toda la Humanidad pueda beneficiarse de las aportaciones de la biología y la medicina;

Reconociendo la importancia de promover un debate público sobre las cuestiones planteadas por la aplicación de la biología y la medicina y sobre las respuestas que deba darse a las mismas;

Deseosos de recordar a cada miembro del cuerpo social sus derechos y responsabilidades;

Tomando en consideración los trabajos de la Asamblea Parlamentaria en este ámbito, comprendida la Recomendación 1160(1991) sobre la elaboración de un Convenio de Bioética;

Decididos a adoptar las medidas adecuadas, en el ámbito de las aplicaciones de la biología y la medicina, para garantizar la dignidad del ser humano y los derechos y libertades fundamentales de la persona,

Han convenido en lo siguiente:

\section{CAPÍTULO I}

Disposiciones generales

Artículo 1. Objeto y finalidad.

Las Partes en el presente Convenio protegerán al ser humano en su dignidad y su identidad y garantizarán a toda persona, sin discriminación alguna, el respeto a su integridad y a sus demás derechos y libertades fundamentales con respecto a las aplicaciones de la biología y la medicina.

Cada Parte adoptará en su legislación interna las medidas necesarias para dar aplicación a lo dispuesto en el presente Convenio.

Artículo 2. Primacía del ser humano.

El interés y el bienestar del ser humano deberán prevalecer sobre el interés exclusivo de la sociedad o de la ciencia.

Artículo 3. Acceso equitativo a los beneficios de la sanidad.

Las Partes, teniendo en cuenta las necesidades de la sanidad y los recursos disponibles, adoptarán las medidas adecuadas con el fin de garantizar, dentro de su ámbito jurisdiccional, un acceso equitativo a una atención sanitaria de calidad apropiada.

Artículo 4. Obligaciones profesionales y normas de conducta.

Toda intervención en el ámbito de la sanidad, comprendida la investigación, deberá efectuarse dentro del respeto a las normas y obligaciones profesionales, así como a las normas de conducta aplicables en cada caso.

\section{CAPÍTULO II}

Consentimiento 
Artículo 5. Regla general.

Una intervención en el ámbito de la sanidad sólo podrá efectuarse después de que la persona afectada haya dado su libre e informado consentimiento.

Dicha persona deberá recibir previamente una información adecuada acerca de la finalidad y la naturaleza de la intervención, así como sobre sus riesgos y consecuencias.

En cualquier momento la persona afectada podrá retirar libremente su consentimiento.

Artículo 6. Protección de las personas que no tengan capacidad para expresar su consentimiento.

1. A reserva de lo dispuesto en los artículos 17 y 20, sólo podrá efectuarse una intervención a una persona que no tenga capacidad para expresar su consentimiento cuando redunde en su beneficio directo.

2. Cuando, según la ley, un menor no tenga capacidad para expresar su consentimiento para una intervención, ésta sólo podrá efectuarse con autorización de su representante, de una autoridad o de una persona o institución designada por la ley.

La opinión del menor será tomada en consideración como un factor que será tanto más determinante en función de su edad y su grado de madurez.

3. Cuando, según la ley, una persona mayor de edad no tenga capacidad, a causa de una disfunción mental, una enfermedad o un motivo similar, para expresar su consentimiento para una intervención, ésta no podrá efectuarse sin la autorización de su representante, una autoridad o una persona o institución designada por la Ley.

La persona afectada deberá intervenir, en la medida de lo posible, en el procedimiento de autorización.

4. El representante, la autoridad, persona o institución indicados en los apartados 2 y 3, recibirán, en iguales condiciones, la información a que se refiere el artículo 5.

5. La autorización indicada en los apartados 2 y 3 podrá ser retirada, en cualquier momento, en interés de la persona afectada.

Artículo 7. Protección de las personas que sufran trastornos mentales.

La persona que sufra un trastorno mental grave sólo podrá ser sometida, sin su consentimiento, a una intervención que tenga por objeto tratar dicho trastorno, cuando la ausencia de este tratamiento conlleve el riesgo de ser gravemente perjudicial para su salud y a reserva de las condiciones de protección previstas por la ley, que comprendan los procedimientos de supervisión y control, así como los de recurso.

Artículo 8. Situaciones de urgencia.

Cuando, debido a una situación de urgencia, no pueda obtenerse el consentimiento adecuado, podrá procederse inmediatamente a cualquier intervención indispensable desde el punto de vista médico a favor de la salud de la persona afectada.

Artículo 9. Deseos expresados anteriormente.

Serán tomados en consideración los deseos expresados anteriormente con respecto a una intervención médica por un paciente que, en el momento de la intervención, no se encuentre en situación de expresar su voluntad.

\section{CAPÍTULO III}

Vida privada y derecho a la información

Artículo 10. Vida privada y derecho a la información.

1. Toda persona tendrá derecho a que se respete su vida privada cuando se trate de informaciones relativas a su salud. 
2. Toda persona tendrá derecho a conocer toda información obtenida respecto a su salud. No obstante, deberá respetarse la voluntad de una persona de no ser informada.

3. De modo excepcional, la ley podrá establecer restricciones, en interés del paciente, con respecto al ejercicio de los derechos mencionados en el apartado 2.

\section{CAPÍTULO IV}

Genoma humano

Artículo 11. No discriminación.

Se prohíbe toda forma de discriminación de una persona a causa de su patrimonio genético.

Artículo 12. Pruebas genéticas predictivas.

Sólo podrán hacerse pruebas predictivas de enfermedades genéticas o que permitan identificar al sujeto como portador de un gen responsable de una enfermedad, o detectar una predisposición o una susceptibilidad genética a una enfermedad, con fines médicos o de investigación médica y con un asesoramiento genético apropiado.

Artículo 13. Intervenciones sobre el genoma humano.

Únicamente podrá efectuarse una intervención que tenga por objeto modificar el genoma humano por razones preventivas, diagnósticas o terapéuticas y sólo cuando no tenga por finalidad la introducción de una modificación en el genoma de la descendencia.

Artículo 14. No selección de sexo.

No se admitirá la utilización de técnicas de asistencia médica a la procreación para elegir el sexo de la persona que va a nacer, salvo en los casos en que sea preciso para evitar una enfermedad hereditaria grave vinculada a sexo.

\section{CAPÍTULO V}

Investigación científica

Artículo 15. Regla general.

La investigación científica en el ámbito de la biología y la medicina se efectuará libremente, a reserva de lo dispuesto en el presente Convenio y en otras disposiciones jurídicas que garanticen la protección del ser humano.

Artículo 16. Protección de las personas que se presten a un experimento.

No podrá hacerse ningún experimento con una persona, a menos que se den las siguientes condiciones:

i) Que no exista un método alternativo al experimento con seres humanos de eficacia comparable.

ii) Que los riesgos en que pueda incurrir la persona no sean desproporcionados con respecto a los beneficios potenciales del experimento.

iii) Que el proyecto de experimento haya sido aprobado por la autoridad competente después de haber efectuado un estudio independiente acerca de su pertinencia científica, comprendida una evaluación de la importancia del objeto del experimento, así como un estudio multidisciplinar de su aceptabilidad en el plano ético.

iv) Que la persona que se preste a un experimento esté informada de sus derechos y las garantías que la ley prevé para su protección.

v) Que el consentimiento a que se refiere el artículo 5 se haya otorgado expresa y específicamente y esté consignado por escrito. Este consentimiento podrá ser libremente retirado en cualquier momento. 
Artículo 17. Protección de las personas que no tengan capacidad para expresar su consentimiento a un experimento.

1. Sólo podrá hacerse un experimento con una persona que no tenga, conforme al artículo 5, capacidad para expresar su consentimiento acerca del mismo, cuando se den las siguientes condiciones:

i) Que se cumplan las condiciones enunciadas en el artículo 16, párrafos (i) a (iv).

ii) Que los resultados previstos del experimento supongan un beneficio real y directo para su salud.

iii) Que el experimento no pueda efectuarse con una eficacia comparable con sujetos capaces de prestar su consentimiento al mismo.

iv) Que se haya dado específicamente y por escrito la autorización prevista en el artículo 6.

v) Que la persona no exprese su rechazo al mismo.

2. De modo excepcional y en las condiciones de protección previstas por la ley, podrá autorizarse un experimento cuyos resultados previstos no supongan un beneficio directo para la salud de la persona si se cumplen las condiciones enumeradas en los párrafos (i), (iii), (iv) y (v) del apartado 1 anterior, así como las condiciones suplementarias siguientes:

i) El experimento tenga por objeto, mediante una mejora significativa del conocimiento científico del estado de la persona, de su enfermedad o de su trastorno, contribuir a lograr en un determinado plazo resultados que permitan obtener un beneficio para la persona afectada o para otras personas de la misma categoría de edad o que padezcan la misma enfermedad o el mismo trastorno, o que presenten las mismas características.

ii) el experimento sólo represente para la persona un riesgo o un inconveniente mínimo.

Artículo 18. Experimentación con embriones «in vitro».

1. Cuando la experimentación con embriones «in vitro» esté admitida por la ley, ésta deberá garantizar una protección adecuada del embrión.

2. Se prohíbe la constitución de embriones humanos con fines de experimentación.

\section{CAPÍTULO VI}

Extracción de órganos y de tejidos de donantes vivos para trasplantes

Artículo 19. Regla general.

1. La extracción de órganos o de tejidos para trasplantes sólo podrá efectuarse de un donante vivo en interés terapéutico del receptor y cuando no se disponga del órgano o del tejido apropiados de una persona fallecida ni de un método terapéutico alternativo de eficacia comparable.

2. El consentimiento a que se refiere el artículo 5 deberá ser expresa y específicamente otorgado, bien por escrito o ante una autoridad.

Artículo 20. Protección de las personas incapacitadas para expresar su consentimiento a la extracción de órganos.

1. No podrá procederse a ninguna extracción de órganos o de tejidos de una persona que no tenga capacidad para expresar su consentimiento conforme al artículo 5.

2. De modo excepcional y en las condiciones de protección previstas por la ley, la extracción de tejidos regenerables de una persona que no tenga capacidad para expresar su consentimiento podrá autorizarse si se cumplen las condiciones siguientes:

i) Si no se dispone de un donante compatible capaz de prestar su consentimiento.

ii) Si el receptor es hermano o hermana del donante.

iii) Si la donación es para preservar la vida del receptor. 
iv) Si se ha dado específicamente y por escrito la autorización prevista en los apartados 2 y 3 del artículo 6, según la ley y de acuerdo con la autoridad competente.

v) si el donante potencial no expresa su rechazo a la misma.

\section{CAPÍTULO VII}

Prohibición del lucro y utilización de una parte del cuerpo humano

Artículo 21. Prohibición del lucro.

El cuerpo humano y sus partes, como tales, no deberán ser objeto de lucro.

Artículo 22. Utilización de una parte extraída del cuerpo humano.

Cuando una parte del cuerpo humano haya sido extraída en el curso de una intervención, no podrá conservarse ni utilizarse con una finalidad distinta de aquélla para la que hubiera sido extraída, salvo de conformidad con los procedimientos de información y de consentimiento adecuados.

\section{CAPÍTULO VIII}

Contravención de lo dispuesto en el Convenio

Artículo 23. Contravención de los derechos o principios.

Las Partes garantizarán una protección jurisdiccional adecuada con el fin de impedir o hacer cesar en breve plazo cualquier contravención ilícita de los derechos y principios reconocidos en el presente Convenio.

Artículo 24. Reparación de un daño injustificado.

La persona que haya sufrido un daño injustificado como resultado de una intervención tendrá derecho a una reparación equitativa en las condiciones y modalidades previstas por la ley.

Artículo 25. Sanciones.

Las Partes deberán prever sanciones apropiadas para los casos de incumplimiento de lo dispuesto en el presente Convenio.

\section{CAPÍTULO IX}

Relación del presente Convenio con otras disposiciones

Artículo 26. Restricciones al ejercicio de los derechos.

1. El ejercicio de los derechos y las disposiciones de protección contenidos en el presente Convenio no podrán ser objeto de otras restricciones que las que, previstas por la ley, constituyan medidas necesarias, en una sociedad democrática, para la seguridad pública, la prevención de las infracciones penales, la protección de la salud pública o la protección de los derechos y libertades de las demás personas.

2. Las restricciones a que se refiere el párrafo precedente no podrán aplicarse a los artículos 11,13 , $14,16,17,19,20$ y 21.

Artículo 27. Protección más amplia.

Ninguna de las disposiciones del presente Convenio deberá interpretarse en el sentido de que limite o atente contra la facultad de cada Parte para conceder una protección más amplia con respecto a las aplicaciones de la biología y la medicina que la prevista por el presente Convenio.

\section{CAPÍTULO X}

Debate público

Artículo 28. Debate público. 
Las Partes en el presente Convenio se encargarán de que las cuestiones fundamentales planteadas por los avances de la biología y la medicina sean objeto de un debate público apropiado, a la luz, en particular, de las implicaciones médicas, sociales, económicas, éticas y jurídicas pertinentes, y de que sus posibles aplicaciones sean objeto de consultas apropiadas.

\section{CAPÍTULO XI}

Interpretación y seguimiento del Convenio

Artículo 29. Interpretación del Convenio.

El Tribunal Europeo de Derechos Humanos podrá emitir dictámenes consultivos, con independencia de todo litigio concreto que se desarrolle ante un órgano jurisdiccional, sobre cuestiones jurídicas relativas a la interpretación del presente Convenio, a solicitud de:

El Gobierno de una de las Partes, una vez informadas las demás Partes.

El Comité instituido por el artículo 32, en su composición restringida a los representantes de las Partes en el presente Convenio, mediante decisión adoptada por mayoría de dos tercios de los votos emitidos.

Artículo 30. Informes sobre la aplicación del Convenio.

Cualquier Parte, a instancias del Secretario General del Consejo de Europa, proporcionará las explicaciones requeridas acerca del modo en que su legislación interna garantiza la aplicación efectiva de todas las disposiciones del presente Convenio.

\section{CAPÍTULO XII}

Protocolos

Artículo 31. Protocolos.

Podrán redactarse protocolos de conformidad con lo dispuesto en el artículo 32, con el fin de desarrollar, en los ámbitos específicos, los principios contenidos en el presente Convenio.

Los protocolos quedarán abiertos a la firma de los signatarios del Convenio. Serán sometidos a ratificación, aceptación o aprobación. Un signatario no podrá ratificar, aceptar o aprobar los protocolos sin haber ratificado, aceptado o aprobado el Convenio con anterioridad o simultáneamente.

\section{CAPÍTULO XIII}

\section{Enmiendas al Convenio}

\section{Artículo 32. Enmiendas al Convenio.}

1. Las tareas encomendadas al Comité en el presente artículo y en el artículo 29 se llevarán a cabo por el Comité Director para la Bioética (CDBI) o por cualquier otro Comité designado a este efecto por el Comité de Ministros.

2. Sin perjuicio de las disposiciones específicas del artículo 29, todo Estado miembro del Consejo de Europa, así como toda Parte en el presente Convenio que no sea miembro del Consejo de Europa, podrá hacerse representar en el seno del Comité cuando aquél desempeñe las tareas confiadas por el presente Convenio, y si dispone de voto en el mismo.

3. Todo Estado a que se refiere el artículo 33 o que haya sido invitado a adherirse al Convenio de conformidad con lo dispuesto en el artículo 34, que no sea Parte en el presente Convenio, podrá designar un observador ante el Comité. Si la Comunidad Europea no es Parte, podrá designar un observador ante el Comité.

4. Con el fin de tener en cuenta los avances científicos, el presente Convenio será objeto de un estudio en el seno del Comité en un plazo máximo de cinco años a partir de su entrada en vigor, y en lo sucesivo, a intervalos que determinará el Comité. 
5. Toda propuesta de enmienda al presente Convenio, así como toda propuesta de Protocolo o de enmienda a un Protocolo, presentada por una Parte, el Comité o el Comité de Ministros, será comunicada al Secretario general del Consejo de Europa, y se transmitirá por mediación del mismo a los Estados miembros del Consejo de Europa, a la Comunidad Europea, a todo Signatario, a toda Parte, a todo Estado invitado a firmar el presente Convenio conforme a lo dispuesto en el artículo 33 y a todo Estado invitado a adherirse al mismo conforme a lo dispuesto en el artículo 34.

6. El Comité examinará la propuesta no antes de dos meses a partir de que le haya sido transmitida por el Secretario general, conforme al párrafo 5. El Comité someterá a la aprobación del Comité de Ministros el texto adoptado por mayoría de dos tercios de los votos emitidos. Una vez aprobado, este texto será comunicado a las Partes para su ratificación, aceptación o aprobación.

7. Toda enmienda entrará en vigor, con respecto a las Partes que la hayan aceptado, el primer día del mes siguiente a la expiración de un período de un mes a partir de la fecha en que hayan comunicado al Secretario general su aceptación cinco Partes, comprendidos al menos cuatro Estados miembros del Consejo de Europa.

Para toda Parte que lo acepte posteriormente, la enmienda entrará en vigor el primer día del mes siguiente a la expiración de un período de un mes a partir de la fecha en que la mencionada Parte haya comunicado al Secretario general su aceptación.

\section{CAPÍTULO XIV}

Cláusulas finales

Artículo 33. Firma, ratificación y entrada en vigor.

1. El presente Convenio queda abierto a la firma de los Estados miembros del Consejo de Europa, de los Estados no miembros que hayan participado en su elaboración y de la Comunidad Europea.

2. El presente Convenio será sometido a ratificación, aceptación o aprobación. Los instrumentos de ratificación, aceptación o aprobación se depositarán en poder del Secretario general del Consejo de Europa.

3. El presente Convenio entrará en vigor el primer día del mes siguiente a la expiración de un período de tres meses a partir de la fecha en que cinco Estados, que incluyan al menos a cuatro Estados miembros del Consejo de Europa, hayan expresado su consentimiento en quedar vinculados por el Convenio conforme a lo dispuesto en el apartado precedente.

4. Para todo Signatario que exprese posteriormente su consentimiento en quedar vinculado por el Convenio, el mismo entrará en vigor el primer día del mes siguiente a la expiración de un período de tres meses a partir de la fecha del depósito de su instrumento de ratificación, aceptación o aprobación.

Artículo 34. Estados no miembros.

1. Una vez entrado en vigor el presente Convenio, el Comité de Ministros del Consejo de Europa podrá invitar a adherirse al presente Convenio, previa consulta a las Partes, a cualquier Estado no miembro del Consejo de Europa, mediante una decisión adoptada por la mayoría prevista en el artículo 20, párrafo d) del Estatuto del Consejo de Europa, y por unanimidad de los votos de los representantes de los Estados Contratantes que tengan derecho a estar representados en el Consejo de Ministros.

2. Para todo Estado adherente, el Convenio entrará en vigor el primer día del mes siguiente a la expiración de un período de tres meses a partir de la fecha del depósito del instrumento de adhesión ante el Secretario general del Consejo de Europa.

Artículo 35. Aplicación territorial.

1. Todo Signatario, en el momento de la firma o en el momento del depósito de su instrumento de ratificación, aceptación o aprobación, podrá designar el territorio o territorios a los que se aplicará el presente Convenio. Cualquier otro Estado podrá formular la misma declaración en el momento de depositar su instrumento de adhesión.

2. Toda Parte, en cualquier momento posterior, podrá extender la aplicación del presente Convenio mediante una declaración dirigida al Secretario general del Consejo de Europa, a cualquier otro territorio 
designado en la declaración y del que asuma las relaciones internacionales o para el que esté habilitado para adoptar decisiones. El Convenio entrará en vigor con respecto a este territorio el primer día del mes siguiente a la expiración de un período de tres meses a partir de la fecha de recepción de la declaración por el Secretario general.

3. Toda declaración hecha en virtud de los dos apartados precedentes podrá ser retirada, en lo que se refiere a cualquier territorio designado en dicha declaración, mediante notificación dirigida al Secretario general. La retirada surtirá efecto el primer día del mes siguiente a la expiración de un período de tres meses a partir de la fecha de recepción de la notificación por el Secretario general.

Artículo 36. Reservas.

1. Cualquier Estado y la Comunidad Europea podrán formular, en el momento de la firma del presente Convenio o del depósito del instrumento de ratificación, aceptación, aprobación o adhesión, una reserva con respecto a una disposición particular del Convenio, en la medida en que una Ley vigente en su territorio no sea conforme a dicha disposición. Las reservas de carácter general no se autorizan según los términos del presente artículo.

2. Toda reserva emitida conforme al presente artículo incluirá un breve informe de la ley pertinente.

3. Toda Parte que extienda la aplicación del presente Convenio a un territorio designado en una declaración prevista en aplicación del apartado 2 del artículo 35, podrá formular una reserva para el territorio de que se trate, conforme a lo dispuesto en los apartados precedentes.

4. Toda Parte que haya formulado la reserva indicada en el presente artículo podrá retirarla por medio de una declaración dirigida al Secretario General del Consejo de Europa. La retirada surtirá efecto el primer día del mes siguiente a la expiración de un período de un mes a partir de la fecha de recepción por el Secretario general.

Artículo 38. Denuncia.

1. Toda Parte podrá denunciar el presente Convenio, en cualquier momento, mediante notificación dirigida al Secretario general del Consejo de Europa.

2. La denuncia surtirá efecto el primer día del mes siguiente a la expiración de un período de tres meses a partir de la fecha de recepción de la notificación por el Secretario General.

Artículo 38. Notificaciones.

El Secretario general del Consejo de Europa notificará a los Estados miembros del Consejo a la Comunidad Europea, a todo Signatario, a toda Parte y a cualquier otro Estado que haya sido invitado a adherirse al presente Convenio:

a) toda firma;

b) el depósito de todo instrumento de ratificación, aceptación, aprobación o adhesión;

c) toda fecha de entrada en vigor del presente Convenio, conforme a sus artículos 33 ó 34;

d) toda enmienda o Protocolo adoptado conforme al artículo 32, y la fecha en la que dicha enmienda o protocolo entren en vigor;

e) toda declaración formulada en virtud de lo dispuesto en el artículo 35;

f) toda reserva y toda retirada de reserva formuladas conforme a lo dispuesto en el artículo 36;

g) cualquier otro acto, notificación o comunicación que tenga relación con el presente Convenio.

En fe de lo cual, los abajo firmantes, debidamente autorizados a estos efectos, han firmado el presente Convenio.

Hecho en Oviedo (Asturias), el 4 de abril de 1997, en francés y en inglés, siendo ambos textos igualmente auténticos, en un solo ejemplar que será depositado en los Archivos del Consejo de Europa. El Secretario general del Consejo de Europa transmitirá copia certificada conforme del mismo a cada uno de los Estados miembros del Consejo de Europa, a la Comunidad Europea, a los Estados no miembros que 
hayan participado en la elaboración del presente Convenio y a todo Estado invitado a adherirse al presente Convenio.

Estados Parte Fecha firma Fecha depósito instrumento

Chipre 30-9-1998 Croacia

7-5-1999 Dinamarca.

4-41997 10-8-1999 Eslovaquia 4-4-1997 15-1-1999 Eslovenia. 4-4-1997 5-11-1999 España 4-4-1997 4-4-1997 Finlandia

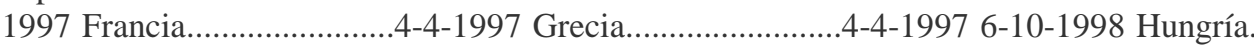
4-4-

5-1999 Islandia ..4-4-1997 Italia. ...4-4-1997 Letonia. 4-4-1997 4-4-1997 Luxemburgo 4-4-1997 Macedonia, ex República de Yugoslavia...4-4-1997 República Moldova........6-5-1997 Noruega.....................4-4-1997 Países Bajos................4-4-1997 Polonia......................7-5-1999 Portugal.....................4-4-1997 Rumania....................4-4-1997 San Marino................4-4-1997 20-3-1998 Suecia......................4-41997 Suiza..........................7-5-1999 Turquía.......................4-4-1997 R R = Reserva.

Conforme al artículo 36 del Convenio, la República de Turquía se reserva el derecho a no aplicar lo dispuesto en el apartado 2 del artículo 20 del Convenio, que autoriza, en ciertas condiciones, la extracción de tejidos regenerables de una persona que no tenga capacidad para dar su consentimiento, ya que esta disposición es contraria a la prohibición establecida en el artículo 5 de la Ley número 2238, sobre extracción, preservación y trasplante de órganos y tejidos.

El presente Convenio entrará en vigor de forma general el 1 de diciembre de 1999 y para España el 1 de enero de 2000, de conformidad con lo establecido en su artículo 33 del mismo.

Lo que se hace público para conocimiento general.

Madrid, 5 de octubre de 1999.-El Secretario general técnico del Ministerio de Asuntos Exteriores, Julio Núñez Montesinos. 


\section{Anexo 3}

CONSELHO FEDERAL DE MEDICINA

RESOLUÇÃO CFM No 1.995, DE 9 DE AGOSTO DE 2012

Diário Oficial da União; Poder Executivo; Brasília, 31 ago. 2012, Seção 1, p.269-270

Dispõe sobre as diretivas antecipadas de vontade dos pacientes.

O CONSELHO FEDERAL DE MEDICINA, no uso das atribuições conferidas pela Lei $\mathrm{n}^{\circ} 3.268$, de 30 de setembro de 1957, regulamentada pelo Decreto $n^{\circ} 44.045$, de 19 de julho de 1958 , e pela Lei $n^{\circ}$ 11.000, de 15 de dezembro de 2004, e

CONSIDERANDO a necessidade, bem como a inexistência de regulamentação sobre diretivas antecipadas de vontade do paciente no contexto da ética médica brasileira;

CONSIDERANDO a necessidade de disciplinar a conduta do médico em face das mesmas;

CONSIDERANDO a atual relevância da questão da autonomia do paciente no contexto da relação médico-paciente, bem como sua interface com as diretivas antecipadas de vontade;

CONSIDERANDO que, na prática profissional, os médicos podem defrontar-se com esta situação de ordem ética ainda não prevista nos atuais dispositivos éticos nacionais;

CONSIDERANDO que os novos recursos tecnológicos permitem a adoção de medidas desproporcionais que prolongam o sofrimento do paciente em estado terminal, sem trazer benefícios, e que essas medidas podem ter sido antecipadamente rejeitadas pelo mesmo;

CONSIDERANDO o decidido em reunião plenária de 9 de agosto de 2012, resolve:

Art. $1^{\circ}$ Definir diretivas antecipadas de vontade como o conjunto de desejos, prévia e expressamente manifestados pelo paciente, sobre cuidados e tratamentos que quer, ou não, receber no momento em que estiver incapacitado de expressar, livre e autonomamente, sua vontade.

Art. $2^{\circ}$ Nas decisões sobre cuidados e tratamentos de pacientes que se encontram incapazes de comunicarse, ou de expressar de maneira livre e independente suas vontades, o médico levará em consideração suas diretivas antecipadas de vontade.

$\S 1^{\circ}$ Caso o paciente tenha designado um representante para tal fim, suas informações serão levadas em consideração pelo médico.

$\S 2^{\circ} \mathrm{O}$ médico deixará de levar em consideração as diretivas antecipadas de vontade do paciente ou representante que, em sua análise, estiverem em desacordo com os preceitos ditados pelo Código de Ética Médica.

$\S 3^{\circ}$ As diretivas antecipadas do paciente prevalecerão sobre qualquer outro parecer não médico, inclusive sobre os desejos dos familiares.

$\S 4^{\circ} \mathrm{O}$ médico registrará, no prontuário, as diretivas antecipadas de vontade que lhes foram diretamente comunicadas pelo paciente.

$\S 5^{\circ}$ Não sendo conhecidas as diretivas antecipadas de vontade do paciente, nem havendo representante designado, familiares disponíveis ou falta de consenso entre estes, o médico recorrerá ao Comitê de Bioética da instituição, caso exista, ou, na falta deste, à Comissão de Ética Médica do hospital ou ao Conselho Regional e Federal de Medicina para fundamentar sua decisão sobre conflitos éticos, quando entender esta medida necessária e conveniente.

Art. $3^{\circ}$ Esta resolução entra em vigor na data de sua publicação.

ROBERTO LUIZ D'AVILA

Presidente do Conselho 


\title{
Anexo 4
}

\section{CONSELHO FEDERAL DE MEDICINA}

\author{
RESOLUÇÃO CFM No 1.805/2006 \\ (Publicada no D.O.U., 28 nov. 2006, Seção I, pg. 169)
}

O Conselho Federal de Medicina, no uso das atribuições conferidas pela Lei $\mathrm{n}^{\circ}$ 3.268 , de 30 de setembro de 1957, alterada pela Lei $\mathrm{n}^{\circ} 11.000$, de 15 de dezembro de 2004, regulamentada pelo Decreto ${ }^{\circ} 44.045$, de 19 de julho de 1958, e

CONSIDERANDO que os Conselhos de Medicina são ao mesmo tempo julgadores e disciplinadores da classe médica, cabendo-lhes zelar e trabalhar, por todos os meios ao seu alcance, pelo perfeito desempenho ético da Medicina e pelo prestígio e bom conceito da profissão e dos que a exerçam legalmente;

CONSIDERANDO o art. $1^{\circ}$, inciso III, da Constituição Federal, que elegeu o princípio da dignidade da pessoa humana como um dos fundamentos da República Federativa do Brasil;

CONSIDERANDO $\mathrm{o}$ art. $5^{\circ}$, inciso III, da Constituição Federal, que estabelece que "ninguém será submetido a tortura nem a tratamento desumano ou degradante";

CONSIDERANDO que cabe ao médico zelar pelo bem-estar dos pacientes;

CONSIDERANDO que $\mathrm{o}$ art. $1^{\circ}$ da Resolução CFM $\mathrm{n}^{\circ}$ 1.493, de 20.5.98, determina ao diretor clínico adotar as providências cabíveis para que todo paciente hospitalizado tenha o seu médico assistente responsável, desde a internação até a alta;

CONSIDERANDO que incumbe ao médico diagnosticar o doente como portador de enfermidade em fase terminal;

CONSIDERANDO, finalmente, o decidido em reunião plenária de 9/11/2006,

\section{RESOLVE:}

Art. $1^{\circ}$ É permitido ao médico limitar ou suspender procedimentos e tratamentos que prolonguem a vida do doente em fase terminal, de enfermidade grave e incurável, respeitada a vontade da pessoa ou de seu representante legal.

$\$ \mathbf{1}^{\circ} \mathrm{O}$ médico tem a obrigação de esclarecer ao doente ou a seu representante legal as modalidades terapêuticas adequadas para cada situação.

$\$ \mathbf{2}^{\circ}$ A decisão referida no caput deve ser fundamentada e registrada no prontuário.

$\S \mathbf{3}^{\circ}$ É assegurado ao doente ou a seu representante legal o direito de solicitar uma segunda opinião médica.

Art. $2^{\circ} \mathrm{O}$ doente continuará a receber todos os cuidados necessários para aliviar os sintomas que levam ao sofrimento, assegurada a assistência integral, o conforto físico, psíquico, social e espiritual, inclusive assegurando-lhe o direito da alta hospitalar.

Art. $3^{\mathbf{0}}$ Esta resolução entra em vigor na data de sua publicação, revogando-se as disposições em contrário.

Brasília, 9 de novembro de 2006

\author{
GARÇÃ̃O \\ Presidente
}

EDSON DE OLIVEIRA ANDRADE

LÍVIA BARROS

Secretária-Geral 


\section{Anexo 5}

\section{Lei Estadual n 10.241, de março de 1999 - Dispõe sobre direitos dos usuários de serviços de saúde}

A Lei Estadual 10.241, de 1999, mais conhecida como "Lei Covas", dispõe sobre direitos dos usuários dos serviços de saúde - inclusive o de consentir ou recusar, de forma livre, voluntária e esclarecida, com adequada informação, procedimentos diagnósticos ou terapêuticos a serem nele realizados.

\section{Íntegra}

LEI ESTADUAL $\mathrm{N}^{\circ}$ 10.241, DE $17 \quad \mathrm{DE} \quad$ MARÇO DE Diário Oficial do Estado; Poder Executivo, São Paulo, SP, n.51, 18 mar. 1999. Seção 1, p.1

(Projeto de lei $\mathrm{n}^{\circ}$ 546/97, do deputado Roberto Gouveia - PT)

Dispõe sobre os direitos dos usuários dos serviços e das ações de saúde no Estado e dá outras providências.

O GOVERNADOR DO ESTADO DE SÃO PAULO: Faço saber que a Assembléia Legislativa decreta e eu promulgo a seguinte lei:

Artigo $1^{\circ}$ - A prestação dos serviços e ações de saúde aos usuários, de qualquer natureza ou condição, no âmbito do Estado de São Paulo, será universal e igualitária, nos termos do artigo $2^{\circ}$ da Lei Complementar nº 791 , de 9 de março de 1995.

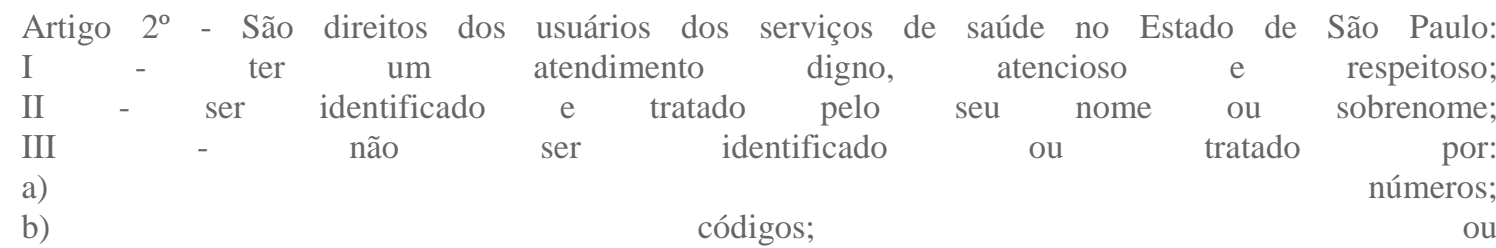

c) de modo genérico, desrespeitoso, ou preconceituoso; IV - ter resguardado o segredo sobre seus dados pessoais, através da manutenção do sigilo profissional, desde que não acarrete riscos a terceiros ou à saúde pública; $\mathrm{V}$ - poder identificar as pessoas responsáveis direta e indiretamente por sua assistência, através de crachás visíveis, legíveis e que contenham: a) nome completo; função;

c) cargo;

d) nome da instituição; VI - receber informações claras, objetivas e compreensíveis sobre: a) hipóteses diagnósticas; b) diagnósticos realizados; c) exames solicitados; d) ações terapêuticas; e) riscos, benefícios e inconvenientes das medidas diagnósticas e terapêuticas propostas; f) duração prevista do tratamento proposto; g) no caso de procedimentos de diagnósticos e terapêuticos invasivos, a necessidade ou não de anestesia, o tipo de anestesia a ser aplicada, o instrumental a ser utilizado, as partes do corpo afetadas, os efeitos colaterais, os riscos e consequiências indesejáveis e a duração esperada do procedimento; h) exames c e condutas a que será submetido; i) a finalidade $\operatorname{dos}$ materiais coletados para exame; j) alternativas de diagnósticos e terapêuticas existentes, no serviço de atendimento ou em outros serviços;

o

que

julgar necessário; 
VII - consentir ou recusar, de forma livre, voluntária e esclarecida, com adequada informação, procedimentos diagnósticos ou terapêuticos a serem nele realizados; VIII - acessar, a qualquer momento, o seu prontuário médico, nos termos do artigo $3^{\circ}$ da Lei $\begin{array}{lllllll}\text { Complementar } & \mathrm{n}^{\circ} & \text { 791, } & \text { de } & 9 & \text { de } & \text { 1995; }\end{array}$ IX - receber por escrito o diagnóstico e o tratamento indicado, com a identificação do nome do profissional e o seu número de registro no órgão de regulamentação e controle da profissão; $\mathrm{X}$

vetado:

vetado;

f)

XI

a)

b)

c)

d) com o nome do profissional e seu número de registro no órgão de controle e regulamentação da profissão;

e) com assinatura do profissional; XII - conhecer a procedência do sangue e dos hemoderivados e poder verificar, antes de recebê-los, os carimbos que atestaram a origem, sorologias efetuadas e prazo de validade; XIII - ter anotado em seu prontuário, principalmente se inconsciente durante o atendimento: a) todas as medicações, com suas dosagens, utilizadas; e b) registro da quantidade de sangue recebida e dos dados que permitam identificar a sua origem, sorologias efetuadas prazo de $\quad$ de XIV - ter assegurado, durante as consultas, internações, procedimentos diagnósticos e terapêuticos e na satisfação de suas necessidades fisiológicas: a) a sua integridade física; b) a $\quad$ privacidade; c) a $\quad$ individualidade; d) 0 respeito aos seus valores éticos e culturais; e) a confidencialidade de toda e qualquer informação pessoal; e f) a segurança do procedimento; XV - ser acompanhado, se assim o desejar, nas consultas e internações por pessoa por ele indicada; XVI - ter a presença do pai nos exames pré-natais e no momento do parto; XVII

XVIII - receber do profissional adequado, presente no local, auxílio imediato e oportuno para a melhoria do conforto e bem estar; XIX - ter um local digno e adequado para o atendimento; XX - receber ou recusar assistência moral, psicológica, social ou religiosa; XXI - ser prévia e expressamente informado quando o tratamento proposto for experimental ou fizer parte de XXII receber anestesia em tod indicadas; extraordinários para tentar prolongar a vida; e XXIV - optar pelo local morte. $\S 1^{\circ}$ - A criança, ao ser internada, terá em seu prontuário a relação das pessoas que poderão acompanhá-la integralmente durante 0 período de internação. $\S 2^{\circ}$ - A internação psiquiátrica observará o disposto na Seção III do Capítulo IV do Título I da Segunda Parte da Lei Complementar nº 791, de 9 de março de 1995.

Artigo

Vetado:

I

II

III

vetado; vetado; vetado.

Parágrafo único - Vetado.

Artigo

vetado; 
Parágrafo único - Vetado.

Artigo

Vetado.

Parágrafo único - Vetado.

Artigo $6^{\circ}$ - Esta lei entrará em vigor na data de sua publicação.

Palácio dos Bandeirantes, 17 de março de 1999.

\section{MÁRIO COVAS}

José

da

Silva

Guedes

Secretário da Saúde

Celino

Secretário-Chefe da Casa Civil

Antonio

Secretário do Governo e Gestão Estratégica

Publicada na Assessoria Técnico-Legislativa, aos 17 de março de 1999.

Diário Oficial do Estado; Poder Executivo, São Paulo, SP, n.51, 18 mar. 1999. Seção 1, p.1 


\section{Anexo 6}

\section{Consulta $\quad n^{\circ} 18.688 / 12$}

Assunto: Sobre a desobrigação dos médicos em prolongar a vida de pacientes terminais.

Relator: Conselheiro Reinaldo Ayer de Oliveira.

Ementa: Reconhecendo que o paciente tem direito a uma morte digna, escolhendo como e onde morrer, recusar ou solicitar certos tratamentos, medicamentos e intervenções, bem assim interrompê-los, é juridicamente possível dispor em documento visando assegurar a garantia constitucional de sua liberdade, inclusive de consciência. Mas não há no ordenamento jurídico pátrio nenhum modelo, fórmula ou previsão legal expressa dos contornos a orientá-lo, porém também não há em sentido contrário, impedindo sua confecção à míngua da previsão de traços que deverá observar. Mas fundamentalmente, mais do que um documento com apelo à formalidade, deverá ser o resultado de um processo envolvendo paciente, familiares, médicos assistentes, a fé religiosa, construído com a conscientização de todos acerca de nossa vontade e nossos desejos, com o respeito às individualidades, e amadurecido com a compreensão e aceitação de nossa finitude.

O consulente Dr. A.C.G.M., pondera que o Conselho Federal de Medicina editou a Resolução CFM ${ }^{\circ}$ 1.805, 09/11/2006, propondo o fim de tratamento "quando não houver mais saída, respeitando vontade do doente e da família" (sic.), e acrescenta supor "que essa questão já esteja definida" (sic.).

À vista disso, consulta este E. Conselho "sobre o que pode e deve um cidadão fazer, em termos documentais, de tal sorte que possa estar assegurado, na condição de paciente terminal, que não será objeto de tratamentos ou procedimentos paliativos, com o objetivo de prolongar inutilmente o que ainda de sobrevida lhe restaria".

Refere que "estamos num país onde a instabilidade jurídica é regra! Assim, para impossibilitar que o Ministério Público queira se imiscuir na relação paciente/médico/paciente, mister se faz munir-se de toda uma documentação".

Por isso solicita "a relação de documentos necessários a tal fim e o dispositivo legal que ampara tal Resolução".

\section{PARECER}

O presente parecer, subscrito por esse Conselheiro, foi elaborado pelo Dr. Antonio Carlos Roselli membro da Câmara Técnica de Bioética do Conselho Regional de Medicina do Estado de São Paulo.

$\underline{\text { Ponderação inicial }}$

A preocupação do consulente acerca de terceiros estranhos à relação médico/paciente, não é infundada, na medida em que a Resolução a que faz referência veio a ser suspensa em sede de liminar deferida em ação civil pública promovida pela Procuradoria da República.

Assim e inicialmente impõe fixar a solução e conseqüente definição a respeito dessa ação.

Ocorreu que o mesmo Ministério Público, agora através de outro de seus membros, a Procuradora Luciana Loureiro Oliveira, atuando nesse processo, ponderou:

"1) o CFM tem competência para editar a Resolução CFM $n^{\circ} 1.805 / 2006$, que não versa sobre direito penal e, sim, sobre ética médica e consequências disciplinares;

2) a ortotanásia não constitui crime de homicídio, interpretado o Código Penal à luz da Constituição Federal;

3) a edição da Resolução CFM n ${ }^{\circ}$ 1.805/2006 não determinou modificação significativa no dia a dia dos médicos que lidam com pacientes terminais, não gerando, portanto, os efeitos danosos propugnados pela inicial;

4) a Resolução CFM $n^{\circ} 1.805 / 2006$ deve, ao contrário, incentivar os médicos a descrever exatamente os procedimentos que adotam e os que deixam de adotar, em relação a pacientes terminais, permitindo maior transparência e possibilitando maior controle da atividade médica; 
5) os pedidos formulados pelo Ministério Público Federal não devem ser acolhidos, porque não se revelarão úteis as providências pretendidas, em face da argumentação desenvolvida."

E com base nessas premissas concluiu postulando fosse julgada improcedente a ação afirmando que:

"Refutamos conveniência de que o Poder Judiciário venha a se pronunciar sobre assunto, mormente nos termos dos pedidos formulados, porque não há ilegalidadel inconstitucionalidade a ser combatida e não compete ao sistema de Justiça, a não ser em face de abuso concreto, limitar a atividade médica ou interferir na relação de confiança entre médico e paciente".

A ação foi julgada improcedente, afirmando-se a:

"convicção de a resolução, que regulamenta a possibilidade de o médico limitar ou suspender procedimentos e tratamentos que prolonguem a vida do doente na fase terminal de enfermidades graves e incuráveis, realmente não ofende o ordenamento jurídico posto".

Assim, fica respondida a primeira parte da Consulta, qual seja a definição da questão relativa à citada Resolução.

Fundamentos.

Posto nesses termos, passo aos fundamentos que conferem ao paciente o direito de decidir e ter respeitada sua vontade e autonomia tocante ao atendimento médico hospitalar e, sobre as normas que o autorizam a dispor em documento suas diretivas de última vontade, ou testamento vital, enquanto ainda guarda condições para assim proceder.

O primeiro e principal fundamento reside no princípio da dignidade (artigo $1^{\circ}$ III, C.R.), erigido a dogma constitucional, materializando atributo com que dotado o indivíduo, visando sua proteção e, especificamente com relação à espécie em comento, assegurando não seja submetido à tortura ou a tratamento degradante (artigo $5^{\circ}$, inciso III).

Com base também nesse princípio, foi editada a Lei Paulista 10.2411, de 1999 (Lei Mario Covas), estabelecendo:

"Art. $2^{\circ}$ - São Direitos dos usuários dos Serviços de Saúde no Estado de São Paulo:

VII - Consentir ou recusar, de forma livre, voluntária e esclarecida, com adequada informação, procedimentos diagnósticos ou terapêuticos a serem nele realizados.

XXIII - Recusar tratamentos dolorosos ou extraordinários para tentar prolongar a vida; $e$,

XXIV - Optar pelo local de morte."

Sobreveio o Código Civil de 2002, prevendo situação assemelhada em seu art. 15:

"Ninguém pode ser constrangido a submeter-se, com risco de vida, a tratamento médico ou a intervenção cirúrgica",

Na mesma senda o Código de Ética Médica (RESOLUÇÃO Conselho Federal de Medicina n ${ }^{\circ}$.931, DE 17 DE SETEMBRO DE 2009) em vigor a partir de 13/04/2010, prevendo dentre seus princípios fundamentais:

"XI - No processo de tomada de decisões profissionais, de acordo com seus ditames de consciência e as previsões legais, o médico aceitará as escolhas de seus pacientes, relativas aos procedimentos diagnósticos e terapêuticos por eles expressos, desde que adequadas ao caso e cientificamente reconhecidas.

XXII - Nas situações clínicas irreversíveis e terminais, o médico evitará a realização de procedimentos diagnósticos e terapêuticos desnecessários e propiciará aos pacientes sob sua atenção todos os cuidados paliativos apropriados."

E no tocante as vedações, dentre elas:

"Art. 22. Deixar de obter consentimento do paciente ou de seu representante legal após esclarecê-lo sobre o procedimento a ser realizado, salvo em caso de risco iminente de morte.

Art. 23. Tratar o ser humano sem civilidade ou consideração, desrespeitar sua dignidade ou discriminá- 
lo de qualquer forma ou sob qualquer pretexto.

Art. 24. Deixar de garantir ao paciente o exercício do direito de decidir livremente sobre sua pessoa ou seu bem-estar, bem como exercer sua autoridade para limitá-lo.

Art. 31. Desrespeitar o direito do paciente ou de seu representante legal de decidir livremente sobre a execução de práticas diagnósticas ou terapêuticas, salvo em caso de iminente risco de morte."

E então fundando nessa estrutura legal, foi editada a Resolução referida na Consulta, que reza expressamente a esse respeito:

"Art. $1^{\circ}$ É permitido ao médico limitar ou suspender procedimentos e tratamentos que prolonguem a vida do doente em fase terminal, de enfermidade grave e incurável, respeitada a vontade da pessoa ou de seu representante legal.

$\S 1^{\circ} \mathrm{O}$ médico tem a obrigação de esclarecer ao doente ou a seu representante legal as modalidades terapêuticas adequadas para cada situação.

$\S 2^{\circ} \mathrm{A}$ decisão referida no caput deve ser fundamentada e registrada no prontuário.

$\S 3^{o} E$ É assegurado ao doente ou a seu representante legal o direito de solicitar uma segunda opinião médica.

Art. $2^{\circ} \mathrm{O}$ doente continuará a receber todos os cuidados necessários para aliviar os sintomas que levam ao sofrimento, assegurada a assistência integral, o conforto físico, psíquico, social e espiritual, inclusive assegurando-lhe o direito da alta hospitalar."

Penso que esses fundamentos são mais do que suficientes para proclamar o direito do paciente em livremente decidir sobre como lhe serão dispensados os atendimentos na hipótese ventilada na Consulta.

Do mesmo sentir o entendimento de Roxana Cardoso Brasileiro Borges: é assegurado o direito à vida (não o dever), mas não se admite que o paciente seja obrigado a ser submeter a tratamento. $\mathrm{O}$ paciente tem o direito de interromper o tratamento com base no direito constitucional de liberdade (inclusive liberdade de consciência), de inviolabilidade de sua intimidade e honra, e, além disso, de respeito à sua dignidade humana.

Adenso ser irretorquível que o paciente não perde seus direitos apenas porque perdeu a capacidade de se comunicar, de expressar sua vontade, ou melhor, porque não pode agora ratificar a vontade e desejo anteriormente externados.

Posta a questão dentro dos contornos normativos, deita-se os olhos sobre a forma ou instrumento com que fará registrar as diretivas que deseja sejam adotadas nas hipóteses que também prever.

Reconhecendo que o paciente tem direito a uma morte digna, escolhendo como e onde morrer, recusar ou solicitar certos tratamentos, medicamentos e intervenções, bem assim interrompê-los, é juridicamente possível dispor em documento visando assegurar a garantia constitucional de sua liberdade, inclusive de consciência.

Mas não há no ordenamento jurídico pátrio nenhum modelo, fórmula ou previsão legal expressa dos contornos a orientá-lo, porém também não há em sentido contrário, impedindo sua confecção à míngua da previsão de traços que deverá observar.

Porém há clara compreensão de seu propósito, para o que empresto a lição de Adriano Marteleto Godinho, no sentido de que "o testamento vital consiste num documento, devidamente assinado, em que o interessado juridicamente capaz declara quais tipos de tratamentos médicos aceita ou rejeita, o que deve ser obedecido nos casos futuros em que se encontre em situação que o impossibilite de manifestar sua vontade, como, por exemplo, o coma. Ao contrário dos testamentos em geral, que são atos jurídicos destinados à produção de efeitos post mortem, os testamentos vitais são dirigidos à eficácia jurídica antes da morte do interessado".

Inexistindo fórmula legal, mas existindo suporte jurídico, o instrumento poderá se assemelhar à figura do instituto do testamento particular de que trata o artigo 1.876, do Código Civil, ou seja, escrito de próprio punho ou mediante processo mecânico.

Se escrito de próprio punho, são requisitos essenciais à sua validade seja lido e assinado por quem o 
escreveu, na presença de pelo menos três testemunhas, que o devem subscrever.

Se elaborado por processo mecânico, não pode conter rasuras ou espaços em branco, devendo ser assinado pelo testador, depois de o ter lido na presença de pelo menos três testemunhas, que o subscreverão.

Mas fundamentalmente, mais do que um documento com apelo à formalidade, deverá ser o resultado de um processo envolvendo paciente, familiares, médicos assistentes, a fé religiosa, construído com a conscientização de todos acerca de nossa vontade e nossos desejos, com o respeito às individualidades, e amadurecido com a compreensão e aceitação de nossa finitude.

Este é o nosso parecer, s.m.j.

Reinaldo

Ayer

de

Oliveira

Coordenador da Câmara Técnica de Bioética

APROVADO NA REUNIÃO DA CÂMARA DE CONSULTAS, REALIZADA EM 13.07.2012. HOMOLOGADO NA 4.495ª REUNIÃO PLENÁRIA, REALIZADA EM 17.07.2012. 


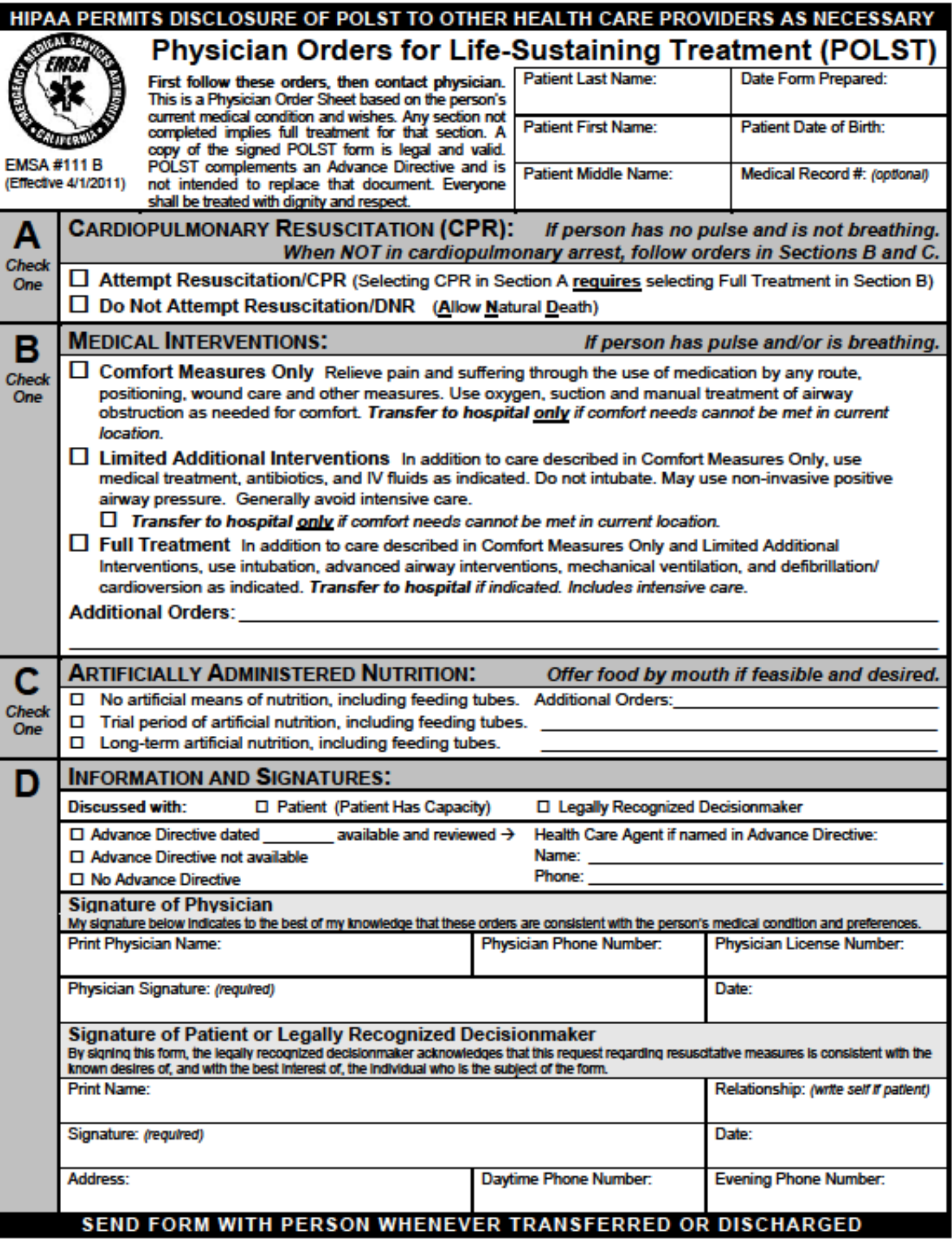

